UNIVERSIDADE DE SÃO PAULO

ESCOLA DE ENGENHARIA DE SÃO CARLOS

DEPARTAMENTO DE ENGENHARIA DE ESTRUTURAS

\title{
A UTILIZAÇÃO DA CINZA DA CASCA DE ARROZ DE TERMOELÉTRICA COMO COMPONENTE DO AGLOMERANTE DE COMPÓSITOS À BASE DE CIMENTO PORTLAND
}

Rafaelle Tiboni 


\section{A UTILIZAÇÃO DA CINZA DA CASCA DE ARROZ DE TERMOELÉTRICA COMO COMPONENTE DO AGLOMERANTE DE COMPÓSITOS À BASE DE CIMENTO PORTLAND}

Dissertação apresentada ao Departamento de Estruturas da Escola de Engenharia de São Carlos da Universidade de São Paulo como requisito para obtenção do título de Mestre em Engenharia Civil.

Área de Concentração: Engenharia das Estruturas

Orientador: Prof. Dr. Jefferson B. L. Liborio. 


\section{AGRADECIMENTOS}

Agradeço primeiramente a Deus que nunca me faltou.

Aos meus pais Vanio e Angélica e minhas irmãs Marcela, Fernanda e Giovanna, que me apoiaram e me incentivaram durante todo o tempo e que eu amo muito.

Ao meu amor, Anselmo Fioranelli Junior, pela compreensão, companheirismo, dedicação e afeto. À família dele pelo incentivo e pela participação.

Ao ombro amigo da minha querida Isabella A. Chaves.

Ao meu orientador Jefferson B. L. Liborio pelos ensinamentos.

Aos colegas e funcionários do Laboratório de Materiais Avançados à Base de Cimento por todo o auxílio em minha pesquisa e pelos momentos de descontração, em especial à Sandra Maria de Lima, à Fernanda Giannotti da Silva e a Rodrigo Vieira da Conceição.

Aos amigos e agregados da turma de 2004 que souberam dosar muito bem dever e diversão.

A todos os funcionários do Laboratório de Estruturas e ao funcionário Paulo Wanderley Pratavieira e ao professor João Adriano Rossignolo do Laboratório de Construção Civil da EESC.

À CAPES por financiar esta pesquisa. 
"Adquirir a sabedoria vale mais que o ouro; antes adquirir a inteligência do que a prata."

(Provérbios, 16:16) 


\section{RESUMO}

TIBONI, R. A Utilização da Cinza da Casca de Arroz de Termoelétrica como Componente do Aglomerante de Compósitos à Base de Cimento Portland. 2007. Dissertação (Mestrado). Departamento de Estruturas, EESC. Universidade de São Paulo. São Carlos - SP, 2007.

A incorporação de resíduos industriais ao concreto, tais como as pozolanas, é uma das soluções para o aproveitamento de subprodutos poluentes estando em acordo com os princípios da sustentabilidade. É objetivo do trabalho discutir e analisar a viabilidade da aplicação de um resíduo das termoelétricas da indústria de beneficiamento do arroz, a cinza da casca de arroz (CCA), como adição mineral em concretos duráveis. Com 88\% de sílica em sua composição, a CCA tem grande potencial de utilização em concretos porque possibilita o aumento da resistência à compressão pelas suas características de alta pozolanicidade e grande finura. Misturas de argamassas padrão contendo $0,5,10$ e 15\% de CCA moídas apenas industrialmente e com moagem adicional de 1 hora, foram confeccionadas a fim de se avaliar o comportamento do aglomerante (CPV - ARI PLUS + CCA) em relação à resistência mecânica. Concretos com traços 1:3,5, 1:5 e 1:6,5, relação água-aglomerante igual a 0,45 e $15 \%$ de CCA foram ensaiados à compressão. Os ensaios mostraram que a CCA é predominantemente cristalina e tem alta pozolanicidade. Quanto às argamassas padrão e aos concretos, os resultados mostraram que a utilização da CCA em compósitos à base de cimento é viável, além de ser ecologicamente correta.

Palavras-chave: Cinza da casca de arroz; Concreto de alto desempenho; Adições minerais; Pozolanas; Resíduos industriais. 


\section{ABSTRACT}

TIBONI, R. The use of thermoeletrical rice husk ash as component of mixtures based in cement agglomerate. 2007. Dissertation (Mester). Structure Department, EESC. University of São Paulo. São Carlos - SP, 2007.

Industrial residues, such as pozzolan, can be incorporated in concretes as a solution for polluter refuses, according to sustainable principles. The objective of this work it is to discuss and analyze the use of rice thermoeletrical industry residue, the rice rusk ash $(\mathrm{RHA})$, as mineral addition in durable concretes. The RHA can be used to increase the compression strength of concretes once it has high pozzolanicity and thinness, composed by $88 \%$ of silica. It was created mixtures of standard mortars containing 0,5 10 and $15 \%$ of industrial grounded $\mathrm{RHA}$ and also with one hour of additional grind. The idea of those mixtures was to evaluate the mechanical strength of the agglomerate (pure Portland cement $+\mathrm{RHA})$. Compression tests in poor, normal and rich concretes with water/agglomerate ratio of 0,45 and $15 \%$ of $\mathrm{RHA}$ were set too. The tests indicated that the $\mathrm{RHA}$ is predominant crystalline and it is a high pozzolanicity material. All the analyses showed that the material has suitable and competitive characteristics for application as agglomerate component.

Key-words: Rice Husk Ash; High performance concrete; Mineral addictions; Pozzolans; Industrial residues. 


\section{SUMÁRIO}

LISTA DE FIGURAS

LISTA DE TABELAS

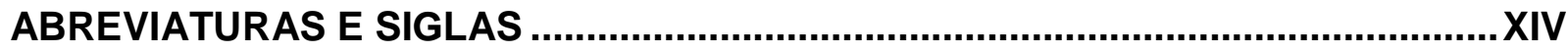

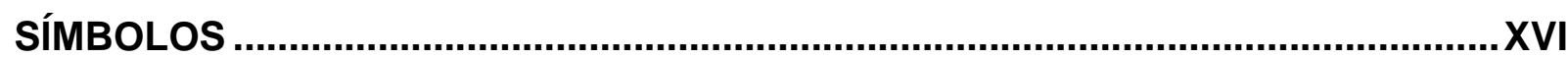

1. INTRODUÇÃO

1.1. FINALIDADE

1.2. OBJETIVO

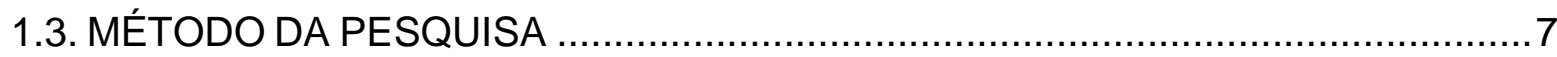

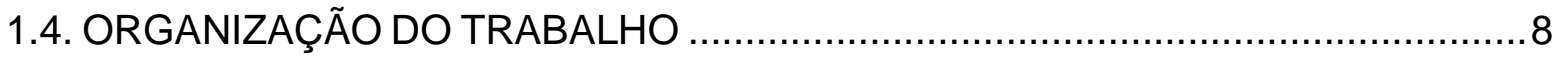

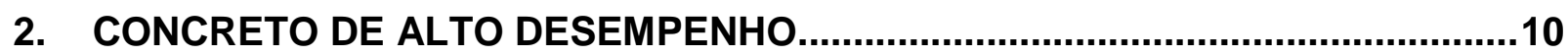

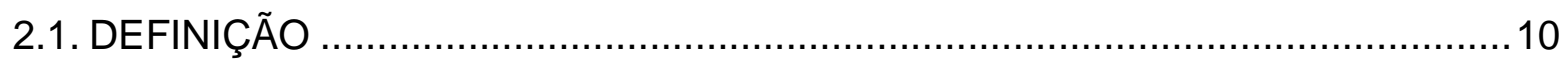

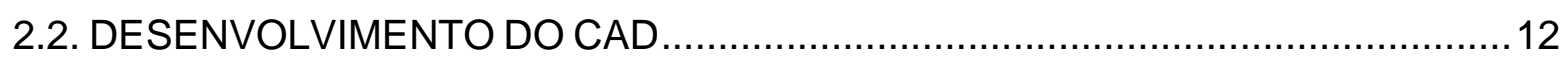

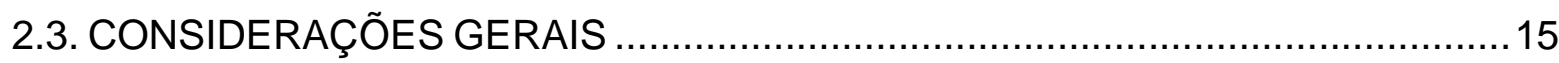

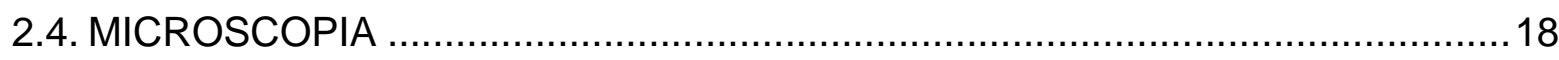

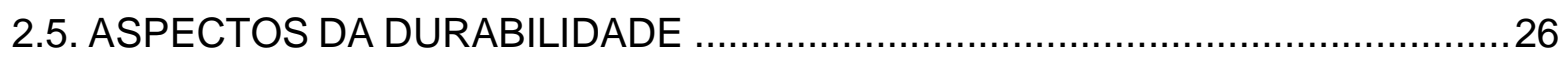

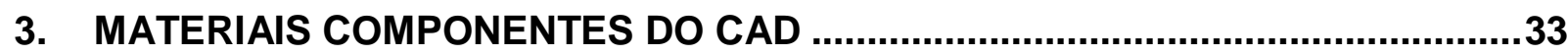

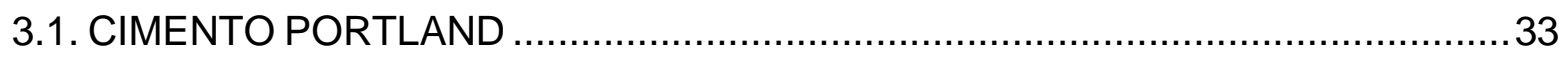

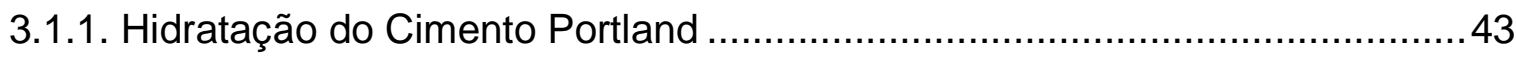

3.1.2. Outros aspectos relacionados ao Cimento Portland ...................................52

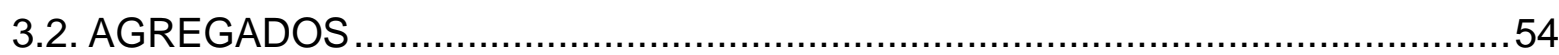

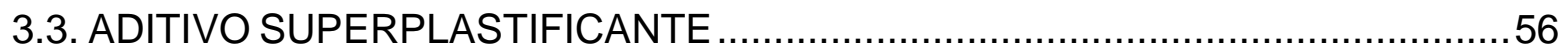

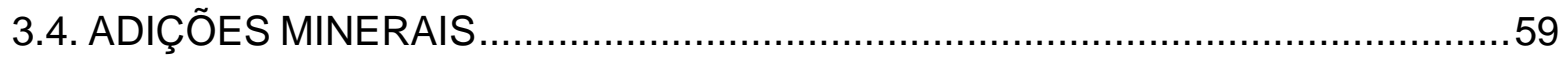

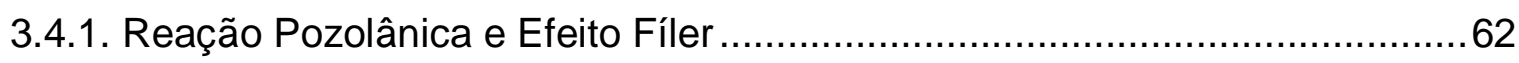

3.4.2. Influência das Adições Minerais em Propriedades Mecânicas.......................66

3.4.3. Outros aspectos relacionados às adições minerais .....................................69 
4. CINZA DA CASCA DE ARROZ

4.1. HISTÓRICO

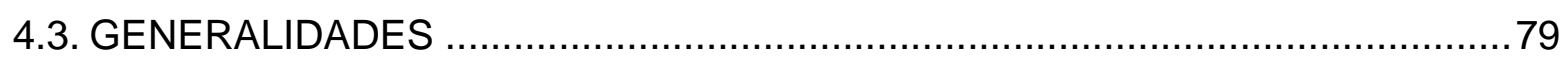

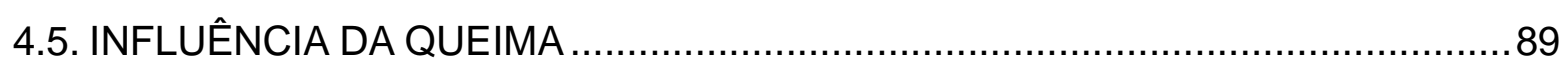

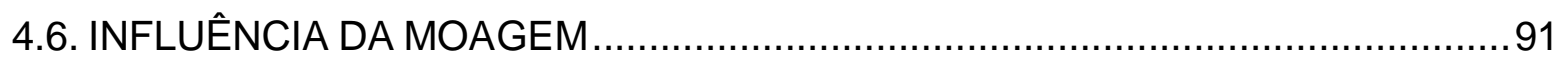

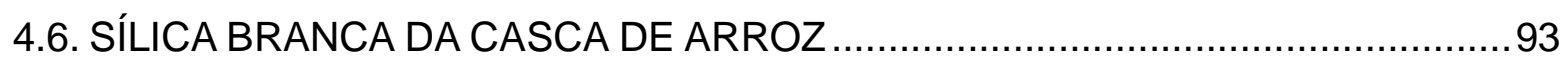

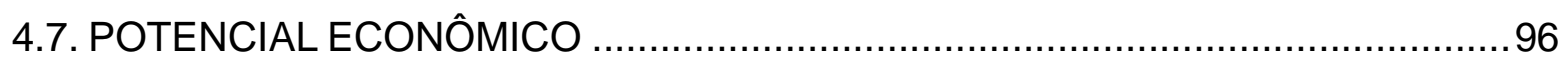

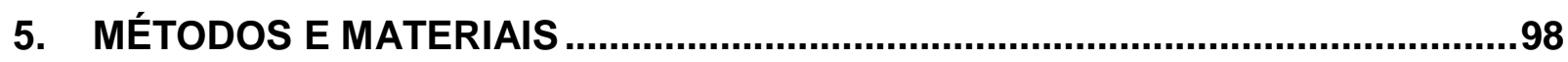

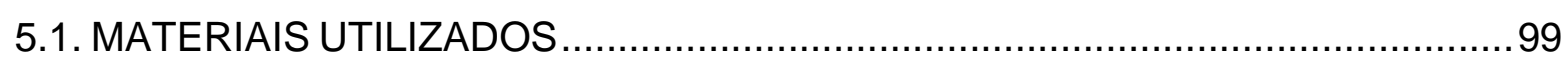

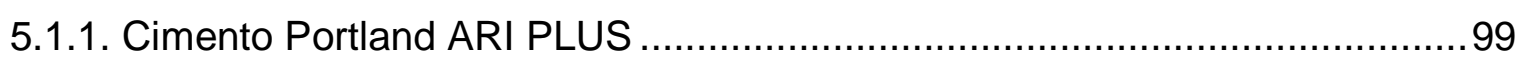

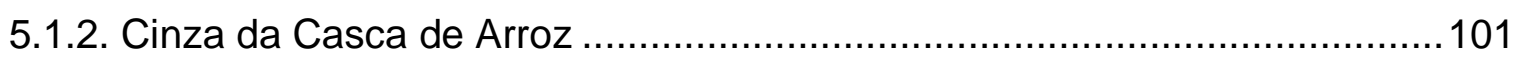

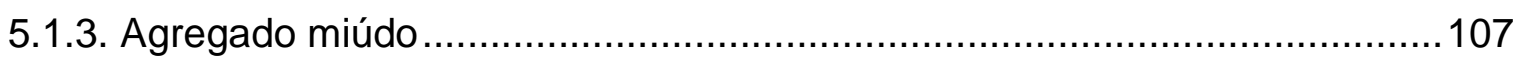

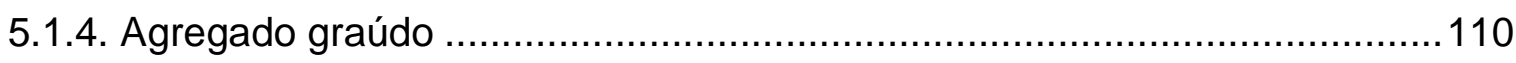

5.2. ENSAIOS DE QUALIDADE E RESISTÊNCIA DO "NOVO CIMENTO" ................113

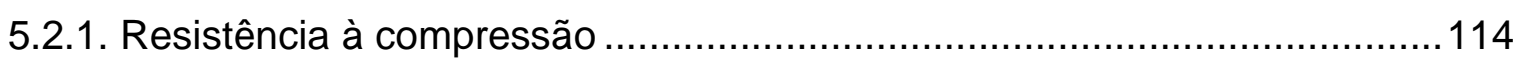

5.2.2. Resistência à tração por compressão diametral ........................................116

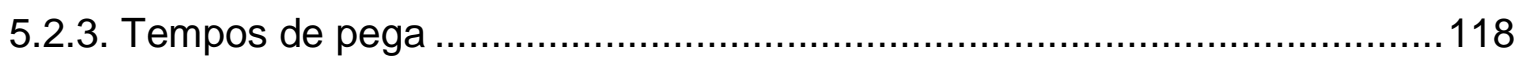

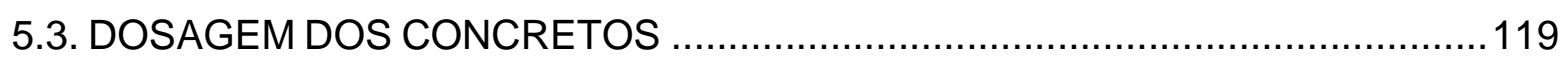

5.4. ENSAIOS MECÂNICOS DOS CONCRETOS COM CCA ……........................125

5.4.1. Resistência à compressão axial ..........................................................125

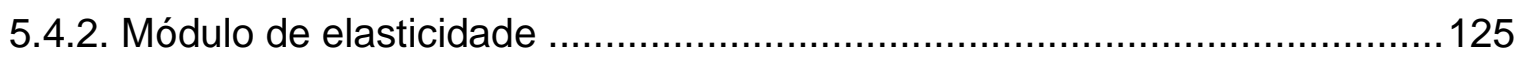

5.4.3. Resistência à tração por compressão diametral ........................................126

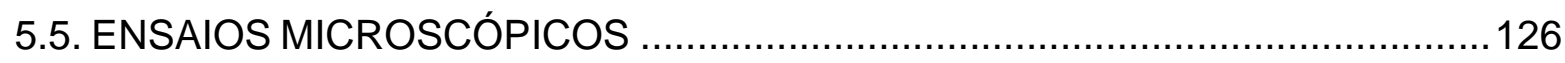

5.5.1. Microscopia Eletrônica de Varredura ...................................................126

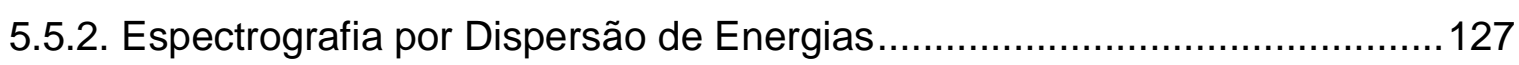

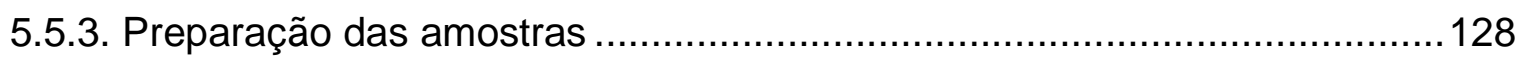

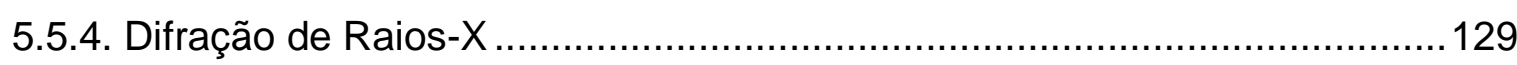

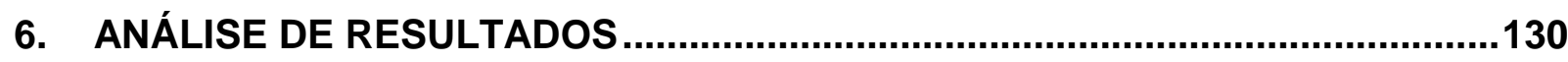

6.1. ENSAIOS DE QUALIDADE DO “NOVO CIMENTO”......................................130

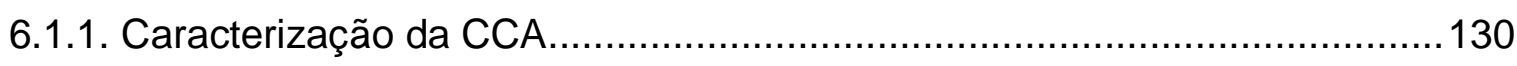

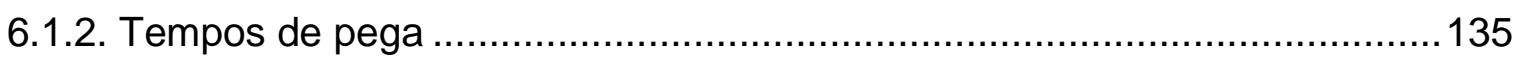


6.1.3. Resistência à compressão de argamassas padrões.................................137

6.1.4. Resistência à tração por compressão diametral de argamassas .................143

6.2. ENSAIOS EM CONCRETOS COM ADIÇÃO DE CCA...................................145

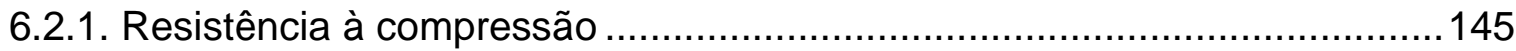

6.2.2. Módulo de elasticidade .................................................................150

6.2.3. Resistência à tração por compressão diametral ..........................................150

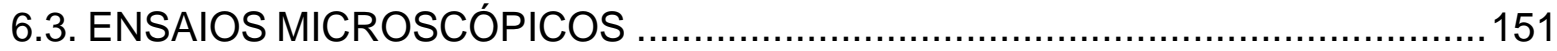

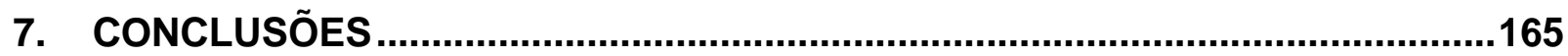

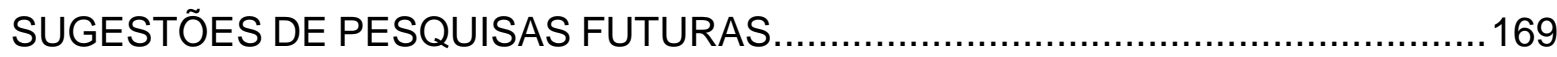

REFERÊNCIAS

ANEXO A

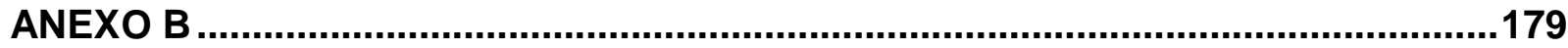




\section{LISTA DE FIGURAS}

Figura 1: Arroz

Figura 2: Depósito de cinza da casca de arroz ao longo de estrada vicinal em Santa Catarina................ 4

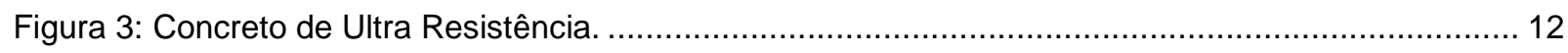

Figura 4: Taipei 101; Curitiba Business Center; e-Tower. ............................................................ 14

Figura 5: Esquema da exsudação interna num agregado lamelar..................................................... 19

Figura 6: Representação diagramática da Z.T. e da matriz de pasta de cimento no concreto................... 21

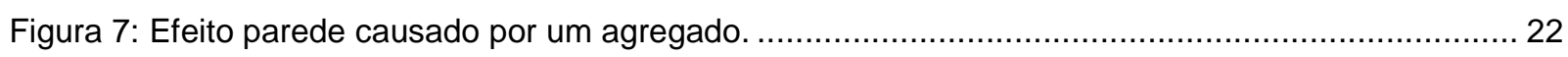

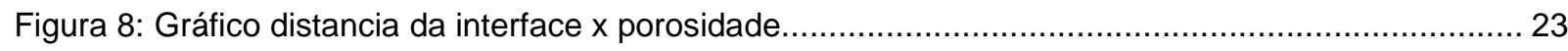

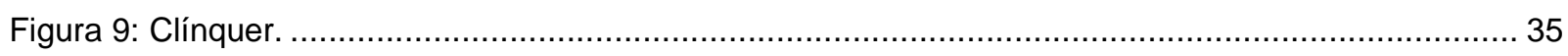

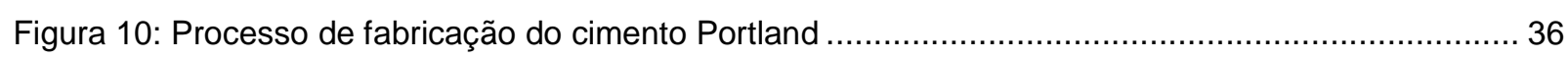

Figura 11: Representação esquemática da formação e hidratação do cimento Portland. ......................... 39

Figura 12: MEV 20.000x e 35.000x - Silicato de cálcio hidratado (C-S-H) ........................................... 40

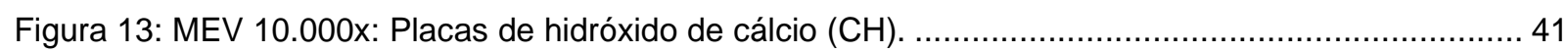

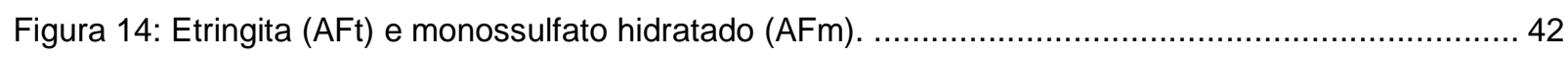

Figura 15: MEV 3.000x: Grão anidro em pasta de cimento Portland ................................................... 43

Figura 16: Evolução da hidratação dos compostos puros do cimento Portland. ..................................... 44

Figura 17. Esquema da hidratação do cimento Portland: mecanismo dissolução-precipitação................ 45

Figura 18. Desenvolvimento da microestrutura durante a hidratação do cimento Portland. ..................... 49

Figura 19: Esquema de agregado frágil, poroso tratado com dopagem superficial................................. 55

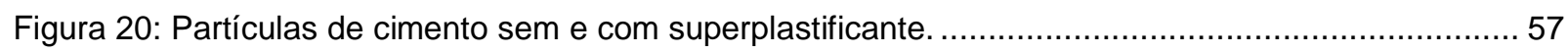

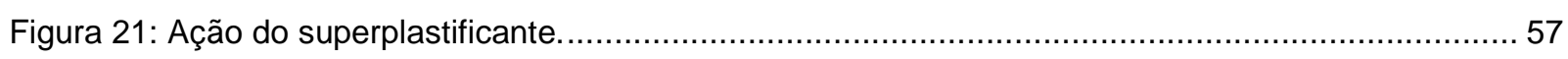

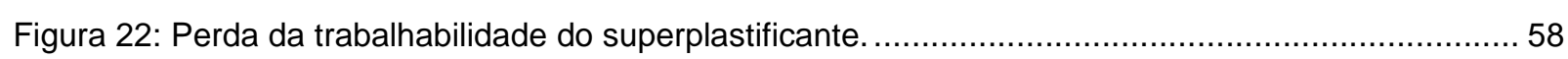

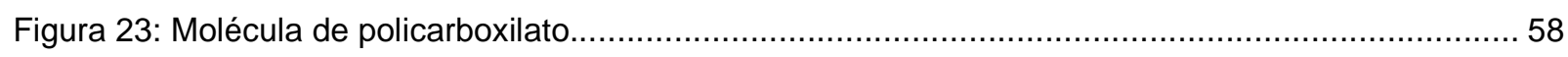

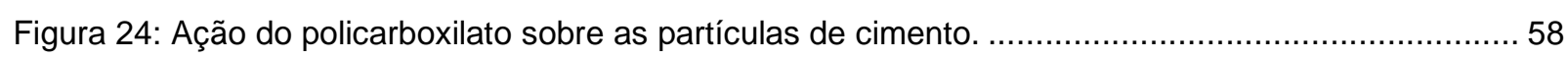

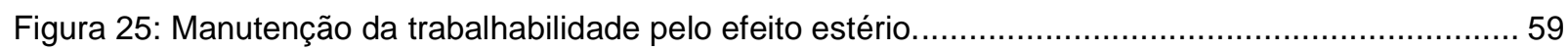

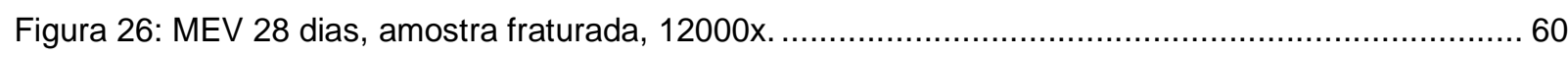

Figura 27: Efeito da sílica de ferro-silício em comparação com o efeito da redução de água. .................. 61

Figura 28: Microestrutura da zona de transição entre a pasta e um grão de agregado............................ 63

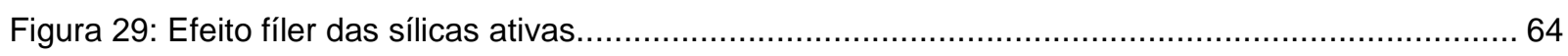

Figura 30: Contribuição dos efeitos pozolânico e fíler na resistência à compressão de concretos............ 64

Figura 31: Efeito da sílica ativa na zona de interface pasta-agregado............................................. 67

Figura 32: Efeito da redução de água e da finura do fíler na resistência à compressão de pastas........... 70 


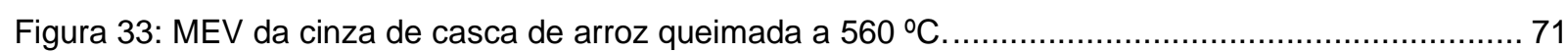

Figura 34: Esquema do fluxo da planta para produzir CCA e vapor. ................................................... 73

Figura 35: Aspecto do concreto fresco confeccionado com cinza da casca de arroz............................... 80

Figura 36: Diagrama de resistência à compressão $x$ tempo; traço 1:3,5:0,28 .................................... 81

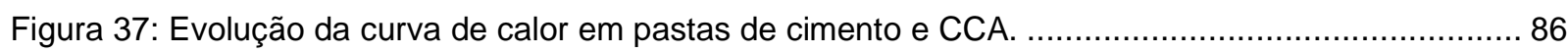

Figura 38: Gráfico mostrando o comportamento da CCA frente à ação ácida. ....................................... 87

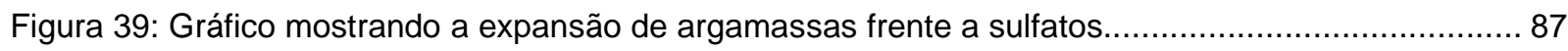

Figura 40: Fator de durabilidade de concretos sujeitos a 300 ciclos de gelo-degelo.............................. 88

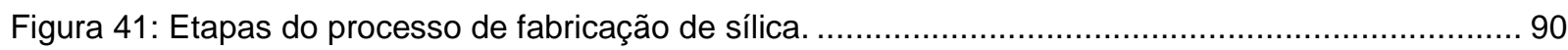

Figura 42: Período efetivo de contribuição na resistência. .............................................................. 91

Figura 43: MEV com o tamanho e formato das partículas de CCA depois da moagem. .......................... 91

Figura 44: Produção da SCA: a) lavagem ácida, b) moinho de bolas e c) forno. ................................... 93

Figura 45: Fornos para fabricação de sílica branca da casca de arroz................................................. 95

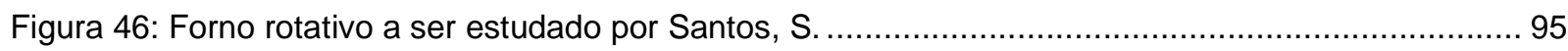

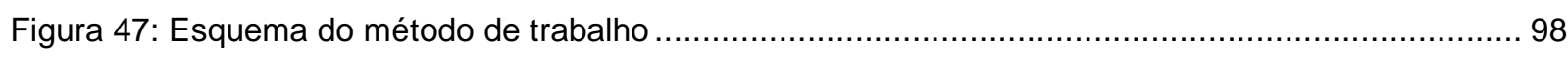

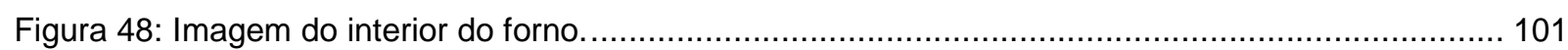

Figura 49: a) Empacotadora; b) Embalagem plástica; c) Armazenagem. ........................................... 102

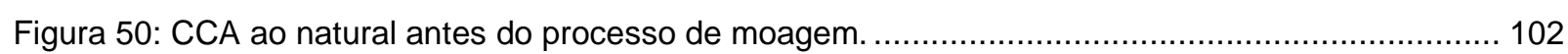

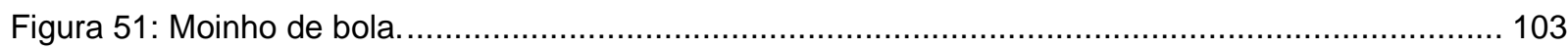

Figura 52: Porcentagem de CCA retida na \#400 x tempo de moagem........................................... 104

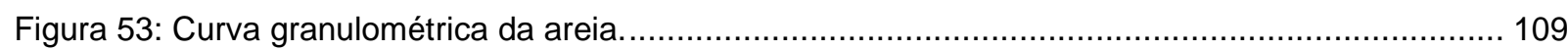

Figura 54: Diâmetro para cálculo do Coeficiente Volumétrico do agregado......................................... 112

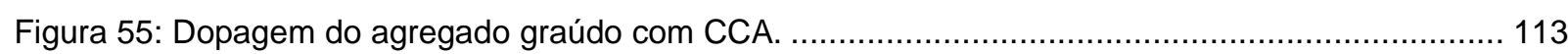

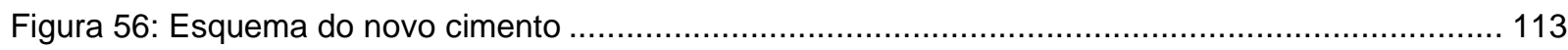

Figura 57: Ensaio de compressão diametral para determinar a resistência à tração indireta. ................ 117

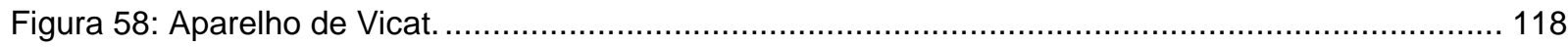

Figura 59: Consumo de água para pasta de consistência normal. ................................................. 119

Figura 60: Curvas de saturação dos aditivos testados................................................................. 122

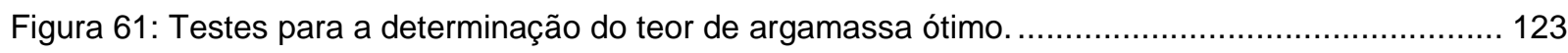

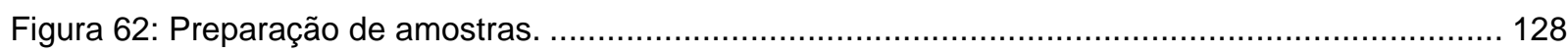

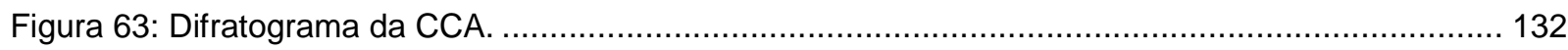

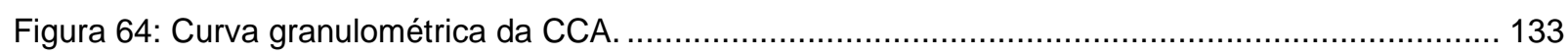

Figura 65: Gráfico de tempos de início e fim de pega de pastas com CCA. ..................................... 136

Figura 66: Gráfico de resistência à compressão de argamassas com CCA sem moer. ......................... 139

Figura 67: Gráfico de resistência à compressão de argamassas com CCA moída por 1h. .................... 139

Figura 68: Gráfico de resistência à compressão de argamassas com 5\% de CCA e REF.................... 140 
Figura 69: Gráfico de resistência à compressão de argamassas com 10\% de CCA e REF. 140

Figura 70: Gráfico de resistência à compressão de argamassas com 15\% de CCA e REF. 140

Figura 71: Gráfico de resistência à tração de argamassas com CCA sem moer. ................................... 143

Figura 72: Gráfico de resistência à tração de argamassas com CCA moída por 1h. ............................. 144

Figura 73: Gráfico de resistência à compressão x idade dos concretos. ........................................... 145

Figura 74: Resistência à compressão $\mathrm{x}$ idade em concretos com e sem aditivo superplastificante......... 146

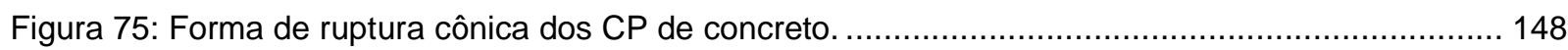

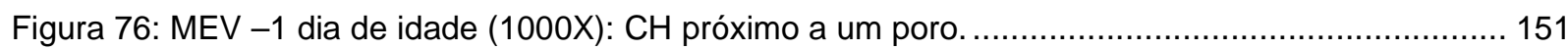

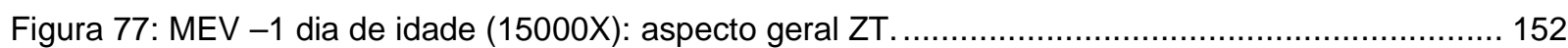

Figura 78: MEV -1 dia de idade (1000X): aspecto geral matriz da pasta. ......................................... 152

Figura 79: MEV -1 dia de idade: CH próximo a um poro; (a) 200X, (b) 15000X ................................. 153

Figura 80: MEV - 3 dias de idade (8000X): aspecto geral matriz da pasta........................................ 153

Figura 81: MEV - 3 dias de idade (15000X): C-S-H na matriz da pasta. ............................................ 154

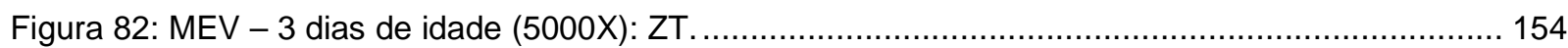

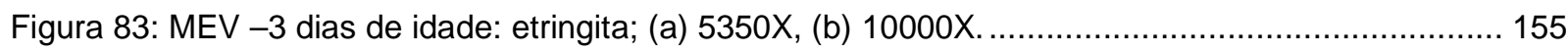

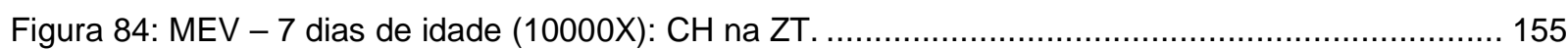

Figura 85: MEV - 7 dias de idade (5000X): $\mathrm{CH}$ e etringita na matriz da pasta. ................................... 156

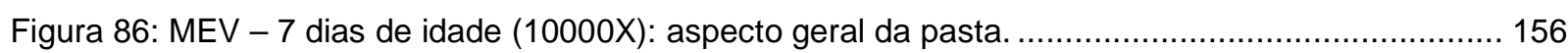

Figura 87: MEV -28 dias de idade: próximo de agregado; (a) 5000X, (b) 10000X, (c) 15000X............ 157

Figura 88: MEV -28 dias de idade: próximo a um poro; (a) 1000X, (b) 5000X, (c) 20000X................. 158

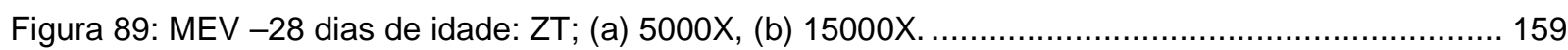

Figura 90: MEV -60 dias de idade: região próxima a um poro; (a) 1000X, (b) 5000X, (c) 20000X........ 160

Figura 91: MEV -60 dias de idade: matriz da pasta; (a) 10000X, (b) 20000X..................................... 161

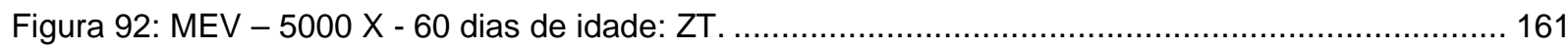

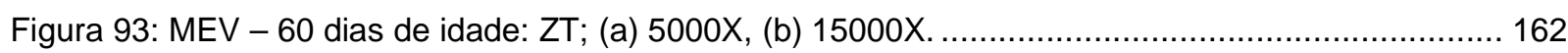

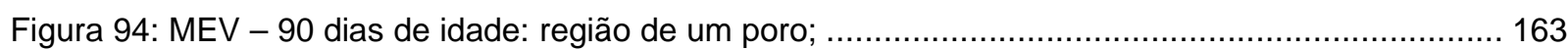

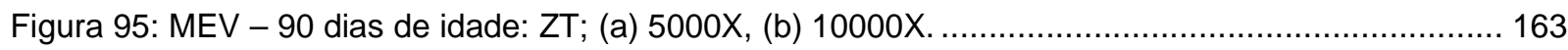

Figura 96: MEV - 90 dias de idade: matriz da pasta; (a) 10000X, (b) 15000X................................... 164 


\section{LISTA DE TABELAS}

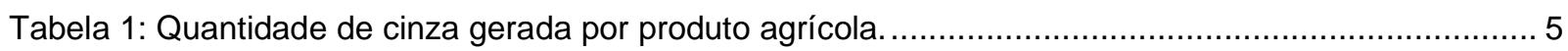

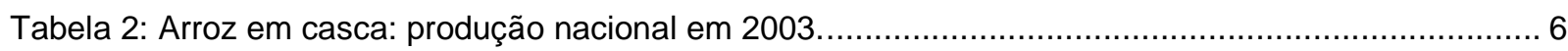

Tabela 3: Classificação do tamanho dos poros na pasta de cimento endurecida. ……........................... 28

Tabela 4: Grau de hidratação necessário para se conseguir a descontinuidade dos poros ..................... 30

Tabela 5: Óxidos oriundos das matérias-primas do cimento Portland. ................................................. 37

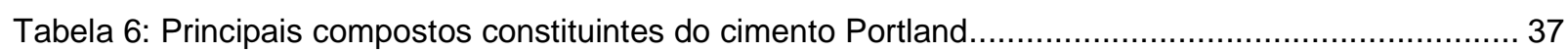

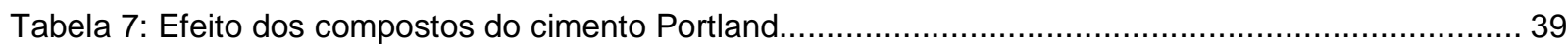

Tabela 8: Resistência à compressão de concretos com adição de CCA. ........................................... 82

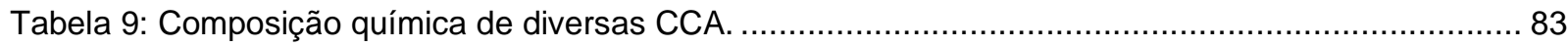

Tabela 10: Comparativo de tempos de pega de misturas com diferentes teores de CCA ........................ 84

Tabela 11: Influência do tempo de moagem na superfície específica e pozolanicidade da CCA. ............92

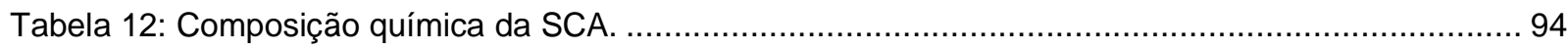

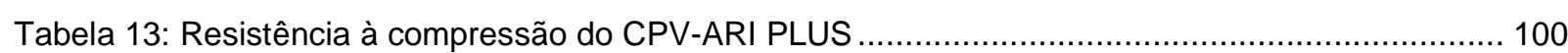

Tabela 14: Propriedades físicas e mecânicas do CPV-ARI PLUS ......................................................... 100

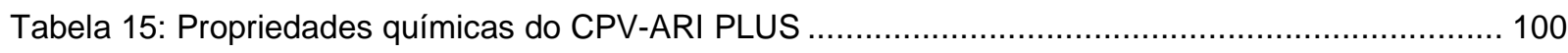

Tabela 16: Frações granulométricas e denominação da Areia Normal............................................... 108

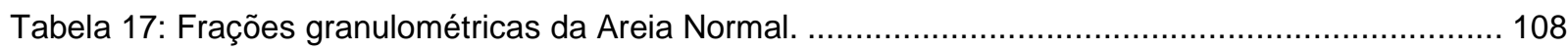

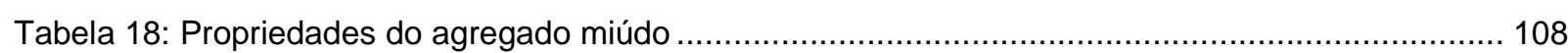

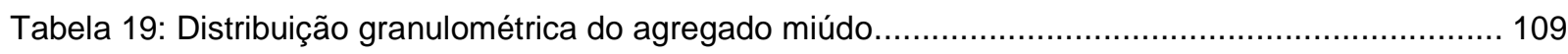

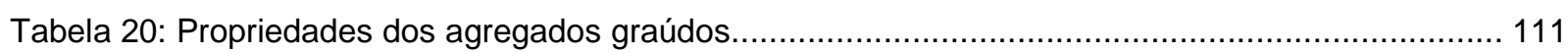

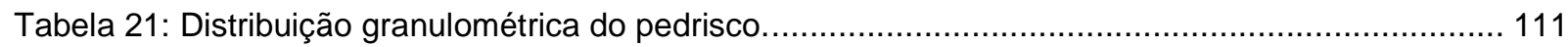

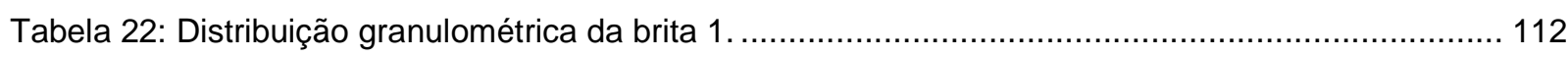

Tabela 23: Argamassas padrão confeccionadas com CCA.......................................................... 115

Tabela 24: Quantidades de materiais para argamassa padrão. ……............................................ 115

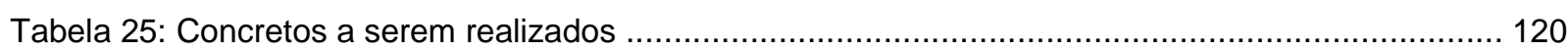

Tabela 26: Correspondência entre classe de agressividade e qualidade do concreto. .......................... 121

Tabela 27: Consumo de materiais para $1 \mathrm{~m}^{3}$ de concreto.............................................................. 123

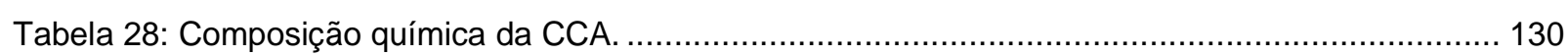

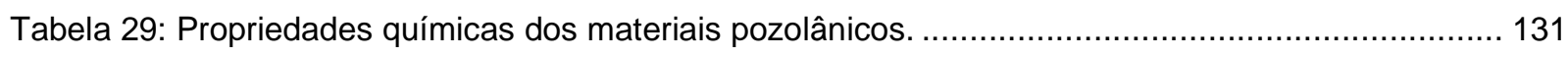

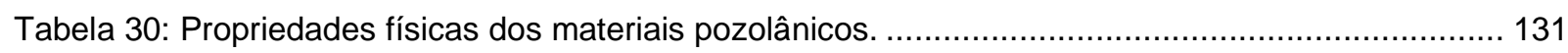

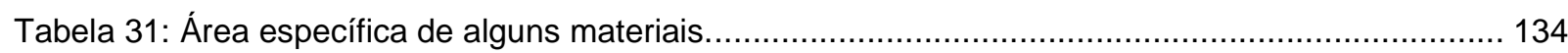

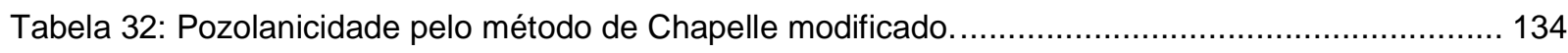

Tabela 33: Índice de atividade pozolânica com o cimento............................................................... 135 
Tabela 34: Tempos de início e fim de pega de pastas com CCA.

Tabela 35: Planilha de análise de variância

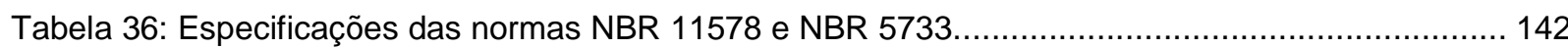

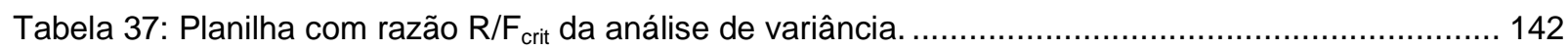

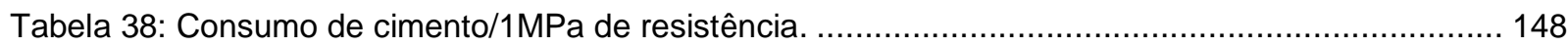

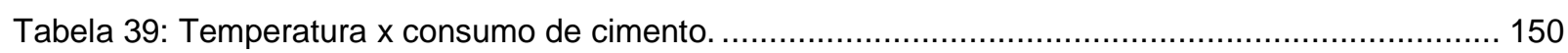

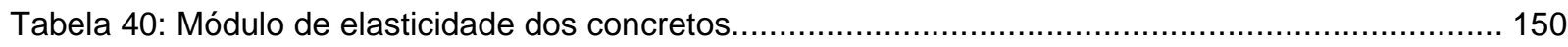

Tabela 41: Resistência à tração por compressão diametral dos concretos.......................................... 150 


\section{ABREVIATURAS E SIGLAS}

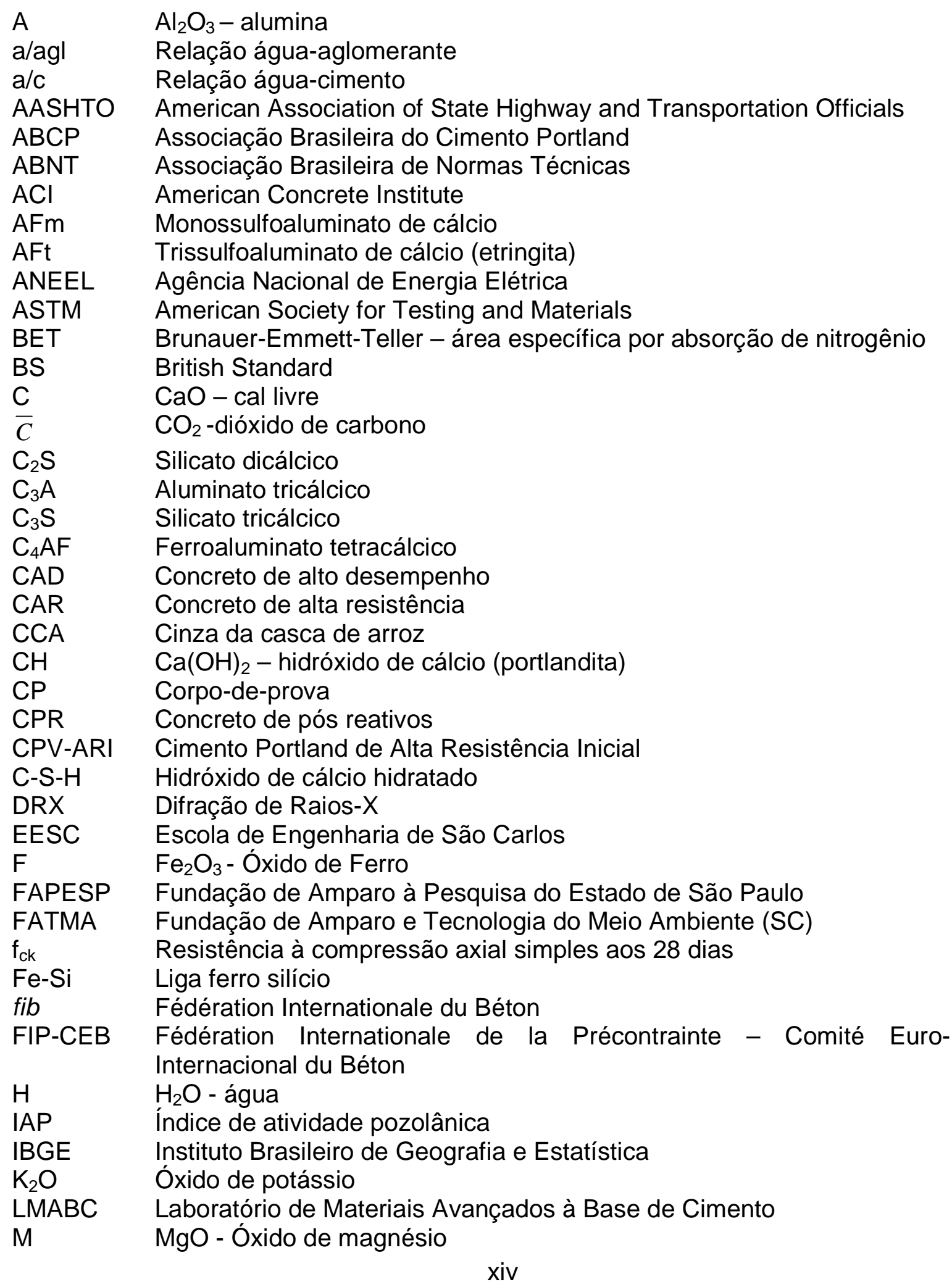




$\begin{array}{ll}\mathrm{MCT} & \text { Ministério da Ciência e Tecnologia } \\ \mathrm{MEV} & \text { Microscopia eletrônica de varredura } \\ \mathrm{MnO}_{2} & \text { Óxido de manganês } \\ \mathrm{NA} & \text { Número de angulosidade } \\ \mathrm{Na}_{2} \mathrm{O} & \text { Óxido de sódio } \\ \mathrm{NBR} & \text { Norma Brasileira Registrada } \\ \text { p.ex. } & \text { Por exemplo } \\ \mathrm{PNUD} & \text { Programa das Nações Unidas para o Desenvolvimento } \\ \mathrm{S} & \mathrm{SiO}_{2} \text { - Óxido de Silício } \\ \overline{\mathrm{S}} & \mathrm{SO}_{3} \text { - Sulfato } \\ \mathrm{SET} & \text { Departamento de Engenharia de Estruturas } \\ \mathrm{TiO}_{2} & \text { Óxido de Titânio } \\ \mathrm{USP} & \text { Universidade de São Paulo }\end{array}$




\section{SíMBOLOS}

$\begin{array}{ll}{ }^{\circ} \mathrm{C} & \text { Grau Célsius } \\ \mathrm{m} & \text { Metro } \\ \mathrm{cm} & \text { Centímetro } \\ \mathrm{mm} & \text { Milímetro } \\ \mu \mathrm{m} & \text { Micrometro }\left(1 \times 10^{-6} \mathrm{~m}\right) \\ \mathrm{nm} & \text { Nanometro }\left(1 \times 10^{-9} \mathrm{~m}\right) \\ \AA & \text { Ângstron }\left(1 \times 10^{-10} \mathrm{~m}\right) \\ \mathrm{m}^{2} & \text { Metro quadrado } \\ \mathrm{cm}^{2} & \text { Centímetro quadrado } \\ \mathrm{mm}^{2} & \text { Milímetro quadrado } \\ \mathrm{m}^{3} & \text { Metro cúbico } \\ \mathrm{l} & \text { Litro } \\ \% & \text { Porcentagem } \\ \mathrm{MPa} & \text { Megapascal }\end{array}$




\section{INTRODUÇÃO}

A sociedade moderna torna-se cada vez mais exigente com relação aos materiais de construção disponíveis no mercado. Uma das razões é o crescente desenvolvimento de novas tecnologias. A escolha de um material deixou de levar em conta apenas o custo inicial. Atualmente, fatores como a durabilidade, consumo energético e a interação com o meio ambiente também devem ser levados em conta, até por que eles influenciam diretamente no custo total do produto final. Já em 1992, Mehta declarou que a escolha dos materiais no futuro deveria atender ao quádruplo enfoque iniciado pela letra "E”: Engenharia, Economia, Energia e Ecologia.

A norma NBR 6118:2003 mostrou preocupação com a durabilidade das estruturas estabelecendo limitações mais conservadoras quanto ao cobrimento mínimo das armaduras, resistência à compressão característica e relação água-cimento. Isto desencadeou uma busca por materiais mais duráveis que proporcionem, por conseguinte, estruturas com vida útil mais longa.

As exigências da norma e a busca por soluções ambientalmente corretas tornaram propícia a utilização das adições minerais na produção de compósitos à base de cimento. Além das adições minerais reduzirem o custo final da estrutura e melhorarem a resistência mecânica e durabilidade dos compósitos nos quais elas são utilizadas, elas também podem minimizar problemas ambientais com a incorporação de resíduos industriais poluentes na massa dos compósitos.

$\mathrm{Na}$ medida em que se observou o crescimento de vários setores industriais, como a fabricação do aço, setor alimentício, outras tantas indústrias, por exemplo, as de produção de ligas de $\mathrm{Fe}-\mathrm{Si}$, silício metálico, as de materiais para 
branqueamento de papéis, etc, foram gerados numerosos resíduos que colaboram na agressão do meio ambiente. Para se obter um equilíbrio, buscaram-se diversas alternativas para o aproveitamento desses resíduos. O cimento Portland é o material mais consumido na face da Terra, superando até mesmo a água (considerando a perda após o tratamento) e, por esta razão, os compósitos à base de cimento tornam-se produtos alternativos para serem associados aos resíduos.

Os resíduos podem reagir com produtos da hidratação dos cimentos ou serem encapsulados nos concretos, evitando-se assim possíveis contaminações. $\mathrm{Na}$ maioria dos casos estes materiais são adicionados ao clínquer, tornando-os elementos barateadores na produção de cimentos. Algumas adições permanecem inertes e têm sua colaboração como fíler para o empacotamento de partículas (efeito fíler), outras reagem com hidratos dos cimentos e se comportam como aglomerantes (efeito pozolânico).

Uma das técnicas que vem sendo estudada está relacionada ao aproveitamento de cinzas provenientes de processos geradores de energia como adições minerais do concreto. Grande parte destas cinzas possui propriedades pozolânicas, ou seja, quando finamente moídos e em presença de umidade, reagem quimicamente com o hidróxido de cálcio formando compostos mais densos e menos solúveis. No caso deste trabalho, o núcleo de estudos refere-se ao subproduto das termoelétricas da indústria de beneficiamento de arroz, a Cinza da Casca de Arroz $(\mathrm{CCA})$.

A cinza da casca de arroz é uma pozolana, e contribui em concretos e argamassas tanto pelo efeito fíler como pelo efeito pozolânico. Suas principais reações químicas benéficas são aquelas com o hidróxido de cálcio $(\mathrm{CH})$, que se transforma de 
material pouco resistente para um material muito resistente e aderente, isto é, em C-SH. Com esta reação, tem sido possível produzir, além de um cimento mais econômico, de mais baixo calor de hidratação, concretos mais resistentes com porosidade desconectada e com resistividade elétrica maior, mais durável frente a vários meios agressivos (SILVA, F.G.;2006).

Figura 1: Arroz.

Fonte: <www.arroz.agr.br> (acesso em 15/06/2005).

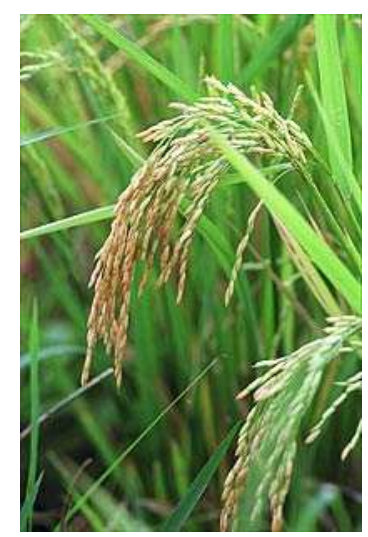

Atualmente, as indústrias de beneficiamento de arroz são ainda as principais consumidoras da casca do cereal como combustível para a secagem e parboilização do arroz. Mudanças ocorridas ao longo do tempo no processo de beneficiamento do arroz obrigaram as usinas a gerarem energia para a secagem do produto. $\mathrm{O}$ que antes era feito com madeira, agora é feito com a incineração da casca do arroz e diesel. Este processo gera um volume demasiado de cinzas sem valor comercial que, normalmente, acabam sendo lançadas nos cursos de água ou em terrenos baldios, ocasionando poluição e contaminação de mananciais e da atmosfera. Como as empresas, geralmente, são de pequeno porte, não possuem processos para aproveitamento e descarte adequados das cinzas produzidas. Para minimizar o problema, órgãos ambientais têm buscado regulamentar o descarte dessas cinzas. No estado de Santa Catarina, por exemplo, a Fundação de Amparo e Tecnologia do Meio Ambiente (FATMA) exige a instalação de um sistema constituído de silo separador e 
decantação para reter a cinza. Como não há emprego para a cinza recolhida, este material estocado acaba sendo lançado de forma clandestina no meio ambiente, muitas vezes ao longo de estradas vicinais, como pode ser observado na Figura 2 (PRUDÊNCIO, SANTOS, DAFICO; 2003).

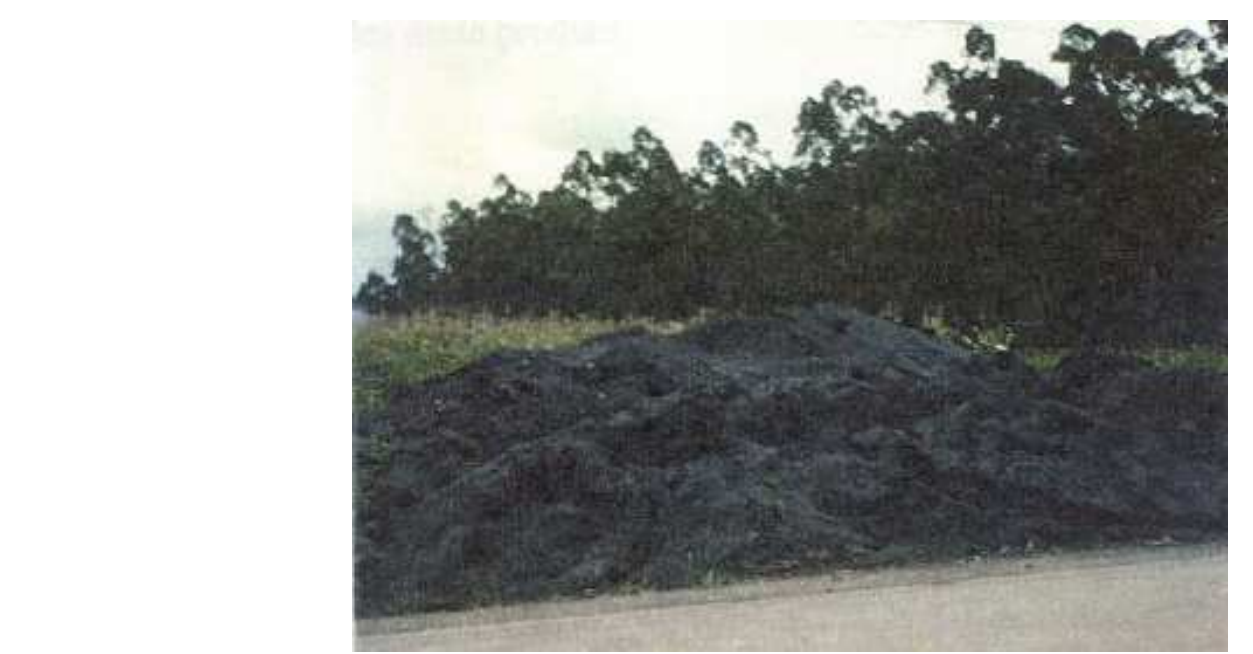

Figura 2: Depósito de cinza da casca de arroz ao longo de estrada vicinal em Santa Catarina. Fonte: Santos, S. (1997).

A cinza da casca de arroz despertou grande interesse na sociedade científica desde os anos 70, principalmente na Índia e nos EUA, mas só a partir da década de 80 , quando a tecnologia do concreto de alto desempenho (CAD) teve grande desenvolvimento, que a preocupação em obter um máximo de pozolanicidade do material se tornou fundamental. A produção de CCA com elevada pozolanicidade possibilita sua utilização no lugar da sílica ativa no concreto de alto desempenho (FAGURY e LIBORIO; 2004). A norma americana ASTM C $989^{1}$ classifica a cinza de casca de arroz, produzida em condições especiais, como pozolana de alta reatividade, juntamente com a sílica ativa de ferro-silício.

\footnotetext{
${ }^{1}$ ASTM C 989 - Standard Specification for Ground Granulated Blast-Furnace Slag for Use in Concrete and Mortars
} 
Uma das razões do interesse pela utilização da CCA é que o volume de cinza produzido quando o arroz é queimado e a porcentagem de sílica na cinza são grandes comparados ao de resíduos de outros produtos agrícolas como o milho, cana de açúcar, girassol, trigo, como é possível observar na Tabela 1. O bagaço da cana e a palha de arroz também são produtos com potencial de utilização de suas cinzas, mas ambos são mais empregados como alimento de animais.

Tabela 1: Quantidade de cinza gerada por produto agrícola.

Fonte: Mehta (1992) e Cook (1986).

\begin{tabular}{cccc}
\hline CEREAL & PARTE DA PLANTA & CINZA (\% em peso) & SILICA (\%) \\
\hline MILHO & FOLHA & 12 & 64 \\
ARROZ & CASCA & 20 & 93 \\
ARROZ & PALHA & 14 & 82 \\
CANA-DE-ACSUCAR & BAGAÇO & 15 & 73 \\
GIRASSOL & FOLHAS TALO & 11 & 25 \\
\hline TRIGO & FOLHAS & 10 & 91 \\
\hline
\end{tabular}

A cinza representa aproximadamente $4 \%$ em massa do arroz em casca. Em 2003, o Brasil foi o 9 maior produtor mundial de arroz, colhendo mais de 10 milhões de toneladas, como está apresentado na Tabela 2. A previsão de safra de arroz do IBGE para o ano de 2005 foi ainda maior, 13.279.816 toneladas. Isto significa que poderiam ser produzidas, se todas as indústrias de beneficiamento de arroz brasileiras tivessem um processo de reciclagem da cinza, 531.193 toneladas de CCA. A produção mundial do cereal deve bater novo recorde em 2005, de acordo com previsão apresentada pela rede $\mathrm{CNN}^{2}$, atingindo 621 milhões de toneladas de arroz. Estes números demonstram que a quantidade de CCA que poderia ser produzida é bastante

\footnotetext{
${ }^{2}$ World Business: Record world rice output tipped <http://edition.cnn.com> (acesso em 13/07/2005).
} 
grande. Como parâmetro de comparação, podemos utilizar a sílica de ferro-silício, cujo maior produtor tem capacidade mundial de 200.000 toneladas/ano ${ }^{3}$.

A utilização da cinza da casca de arroz em substituição de parte do clínquer do cimento Portland na produção de concretos e argamassas, em proporções adequadas, é justificada pela melhoria de propriedades mecânicas e de durabilidade e, sobretudo, no que diz respeito à preservação do meio ambiente e na economia de energia. Esta última vantagem provém da redução do consumo de clínquer, que é a parte do cimento que mais necessita de energia para ser produzida (1450으.

Tabela 2: Arroz em casca: produção nacional em 2003.

Fonte: <http://www.geohive.com> (acesso em 13/07/2005)

\begin{tabular}{|c|c|c|}
\hline CLASSIF. & PAÍS & PRODUÇÃO (ton) \\
\hline 10 & CHINA & 166.417 .000 \\
\hline 20 & INDIA & 132.013 .000 \\
\hline $3^{\circ}$ & INDONESIA & 52.078 .832 \\
\hline $4^{\circ}$ & BANGLADESH & 38.060 .000 \\
\hline $5^{\circ}$ & VIETNA & 34.518 .600 \\
\hline $6^{\circ}$ & TAILANDIA & 27.000 .000 \\
\hline $7^{\circ}$ & MIANMA & 24.640 .000 \\
\hline 80 & FILIPINAS & 14.031 .000 \\
\hline 9ㅇ' & BRASIL" & 10.198 .900 \\
\hline
\end{tabular}

\subsection{FINALIDADE}

É finalidade deste trabalho estimular o aproveitamento da cinza da casca de arroz produzida na termoelétrica da empresa Urbano Agroindustrial no Rio Grande do Sul, que atualmente é tratada como lixo industrial, incorporada em argamassas e concretos, indicando procedimentos essenciais para a sua caracterização, seleção e aplicação, de modo a se obter misturas viáveis e ambientalmente corretas. Este estímulo será feito com a publicação de artigos e apresentação de palestras para

\footnotetext{
${ }^{3}$ Elkem Materials: www.microsilica.com.br (acesso em 04/10/2005).
} 
desmistificar a problemática relacionada à utilização de tal adição, além de apontar suas vantagens e precauções.

\subsection{OBJETIVO}

Essa pesquisa tem como objetivo o estudo de propriedades da cinza da casca de arroz e análise de sua viabilidade como componente de aglomerantes para compósitos à base de cimento Portland ecologicamente corretos.

\subsection{MÉTODO DA PESQUISA}

Foram elaboradas misturas binárias compostas de cimento CPV-ARI PLUS e 0, 5, 10 e 15\% de adição de cinza da casca do arroz sem moagem adicional, ou seja, moída somente industrialmente, e moída em moinho de bolas pelo período de uma hora, em laboratório. Foi analisado o comportamento da cinza em relação ao tempo de pega, consumo de água e tempo de moagem. Então foi avaliada a sinergia entre esta pozolana e o cimento Portland e determinada a melhor entre as proporções sugeridas mecanicamente. O aglomerante produzido por esta proporção de CCA e cimento foi selecionado para compor as misturas de concreto.

Para uma posterior comparação da cinza da casca de arroz com outras adições minerais, o material foi aplicado a um produto, o concreto de alto desempenho com relação água-aglomerante de aproximadamente 0,45 e abatimento do tronco de cone de $130 \pm 20 \mathrm{~mm}$. Foram moldados corpos-de-prova com esta mistura que, então, foram ensaiados mecanicamente à compressão simples, à tração por compressão 
diametral para demonstrar o potencial da cinza de casca de arroz. Este foi ensaiado e comparado a concretos similares sem adição de CCA.

\subsection{ORGANIZAÇÃO DO TRABALHO}

O trabalho encontra-se dividido em 7 capítulos.

O primeiro capítulo introduziu o tema do trabalho, mostrando sua importância num contexto geral, os resultados esperados, assim como o porquê da escolha do assunto. O Capítulo 1 também trata dos objetivos e finalidades a que se pretende alcançar com o presente estudo.

O capítulo 2 aborda o assunto "concreto de alto desempenho". Ele visa estabelecer o que é CAD e as principais diferenças entre este concreto e o convencional, principalmente sob o foco da durabilidade. Porosidade, permeabilidade, microscopia, cura e resistência mecânica são alguns dos assuntos abordados. Este capítulo se faz necessário porque o CAD com adição de cinza da casca de arroz foi produto de análise desta pesquisa.

O terceiro capítulo ainda trata do tema "concreto de alto desempenho", mas sob o ponto de vista dos materiais que o compõem e a maneira como cada um afeta as propriedades do concreto. Os materiais estudados são: cimento Portland, agregado graúdo, agregado miúdo, superplastificante e adições minerais.

No capítulo 4, "cinza da casca de arroz", o material é descrito com ênfase na sua aplicação em argamassas e concretos. São comentados e analisados diversos resultados de publicações anteriores. 
O capítulo 5 é composto pelo programa experimental e o estudo dos materiais que são usados nesta pesquisa. Descreve os procedimentos ou cita as normas utilizadas para a realização dos ensaios, assim como apresenta as propriedades dos materiais e outros parâmetros estabelecidos.

No sexto capítulo realiza-se a análise dos resultados, por meio da apresentação dos dados e comparação com publicações anteriores.

As conclusões finais e as sugestões para futuras pesquisas encontram-se no capítulo 7. As referências citadas no texto foram apresentadas na seqüência. 


\section{CONCRETO DE ALTO DESEMPENHO}

\subsection{DEFINIÇÃO}

Concreto de Alto Desempenho (CAD) é o termo utilizado para designar concretos com uma variedade de propriedades e particularidades melhoradas. Um concreto será assim denominado se atender às solicitações e ações para a qual foi projetado durante a sua vida útil. Segundo a NBR 6118:2003, vida útil é o período de tempo durante o qual se mantêm as propriedades das estruturas de concreto, desde que atendidos os requisitos de uso e manutenção prescritos pelo projetista e pelo construtor, bem como de execução dos reparos necessários decorrentes de danos acidentais.

Com os avanços na tecnologia do concreto nas últimas décadas, o conceito de concreto de alto desempenho vem se alterando, assim como os materiais que fazem parte de sua composição, como é o caso do cimento, adições e aditivos. Mesmo nos dias de hoje, a definição de concreto de alto desempenho ainda não é suficientemente precisa. Um dos motivos que isto ocorre é porque algumas referências utilizam erroneamente o termo CAD para o Concreto de Alta Resistência (CAR), que é o concreto que possui elevada resistência à compressão. Na verdade, a alta resistência mecânica é apenas um dos fatores a ser considerado no projeto de um traço de concreto. A maioria das definições encontradas é feita ou com base na resistência à compressão do concreto aos 28 dias $\left(f_{c k}\right)$, ou com base na relação água-aglomerante. Porém, outros fatores podem ser considerados importantes no CAD, são eles: elevada resistência à abrasão, estabilidade dimensional adequada, baixa permeabilidade, alta resistência à penetração de cloretos, etc. 
O CEB/FIP:1990 estabelece que o Concreto de Alto Desempenho é aquele com $\mathrm{f}_{\mathrm{ck}}$ entre $60 \mathrm{MPa}$ e $130 \mathrm{MPa}$, sendo o limite superior o viável para concretos com agregados convencionais. Já para a Mehta e Monteiro (1994), um concreto será considerado de alto desempenho se possuir $f_{c k}$ superior a $40 \mathrm{MPa}$. O ACI 363R-92 considera este valor igual a $41 \mathrm{MPa}$, mas admite que a definição varia geograficamente. Em regiões onde concretos com resistência em torno de 60MPa são produzidos comercialmente, concreto de alto desempenho é considerado aquele com $\mathrm{f}_{c k}$ entre $80 \mathrm{e}$ 100MPa. Entretanto em regiões onde a média comercial máxima é de aproximadamente $35 \mathrm{MPa}$, um concreto com $\mathrm{f}_{\mathrm{ck}}$ igual a $60 \mathrm{MPa}$ é um concreto de alto desempenho.

Aïtcin (2000) e Neville (1997) utilizam a relação água-aglomerante para a classificação. O primeiro diz que esta deve ser menor que 0,40 e o segundo estabelece que deve ser menor que 0,35 . Percebe-se que ambos concordam que a relação deve ser baixa. Posteriormente este importante fundamento do concreto de alto desempenho será melhor detalhado.

Uma definição bastante pertinente de Concreto de Alto Desempenho vem de Silva e Liborio (1999) que ressaltam que este deve ser caracterizado e definido em função das suas características globais, que são evidenciadas pelo seu comportamento por meio das avaliações das propriedades mecânicas, da durabilidade, da característica da microestrutura e do meio ao qual está inserido. Nota-se que nesta definição não é levado em consideração apenas as propriedades do material, mas também a sua finalidade. 
Atualmente já é possível definir Concretos de Ultra Desempenho, como o produzido por Liborio, Helene, Silva F.G, Castro A.L. e Silva V.M (LIBORIO; 2004) o qual atingiu 145MPa e 210MPa em 1 e 3 dias de idade respectivamente (Figura 3).

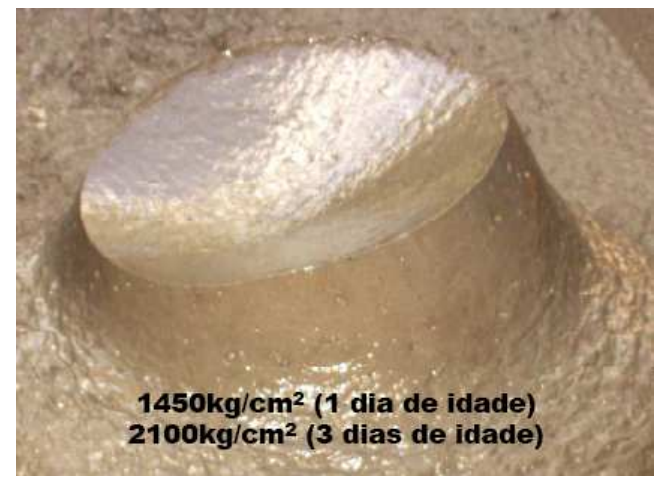

Figura 3: Concreto de Ultra Resistência. Fonte: (LIBORIO; 2004).

\subsection{DESENVOLVIMENTO DO CAD}

O concreto de alto desempenho foi introduzido lentamente no mercado mundial, particularmente nos edifícios de grande altura e obras especiais. Na década de 50 , concretos com $\mathrm{f}_{\mathrm{ck}}$ de $35 \mathrm{MPa}$ eram considerados de alta resistência. $\mathrm{Na}$ década de 60 , os concretos de $40 \mathrm{MPa}$ e $50 \mathrm{MPa}$ já estavam disponíveis comercialmente. No início dos anos 70, os concretos atingiram a resistência de 60MPa. Durante os anos 80, com o advento do superplastificante e a utilização de adições minerais como a sílica ativa, atingiram-se resistências de 100MPa. Nos anos 90, resistências na ordem de 140MPa então foram alcançadas na construção de edifícios altos (CEB/FIP:1990; ACI 363R-92: 2001; AÏTCIN; 2000). Atualmente, novos materiais têm sido estudados como possíveis componentes do concreto. Em seu estudo, Vanderlei (2004) apresentou um compósito que alcança resistências de 145MPa em apenas um dia com a tecnologia dos concretos de pós-reativos (CPR). Estes são formados de partículas com diâmetro máximo menor que $2 \mathrm{~mm}$. Como conseqüência da sua composição, minimizam-se 
defeitos, tais como microfissuras e poros, o que permite à estrutura resistir a maiores tensões. Os materiais que geralmente compõem o concreto de pós-reativos são: areia muito fina de quartzo, cimento, pó de quartzo, sílica ativa (que são os pós ou finos), água, superplastificantes de última geração e pequenas fibras de aço. As relações água-cimento são muito baixas (aproximadamente 0,18). Este concreto apresenta comportamento de elevado desempenho, principalmente em relação à permeabilidade, que é baixíssima, e à resistência mecânica, que é elevada. Richard (1996) menciona a existência de concretos com até $800 \mathrm{MPa}$, com a aplicação de pressurização antes da moldagem.

Silva, I. J. (2000) relata que a aplicação do concreto de alto desempenho encontrou alguns obstáculos, tais como a reduzida trabalhabilidade das misturas inicialmente desenvolvidas, o conservadorismo de arquitetos e engenheiros, a pequena disponibilidade comercial em centrais pré-misturadoras, as limitações impostas pelos códigos de obra e/ou de cálculo estrutural, o desconhecimento do comportamento ao longo do tempo do material, etc., até atingir o estágio atual em que é considerado bom material de construção e cujo consumo começa a aumentar.

No mundo são diversos os exemplos de edifícios e grandes obras executadas com CAD. Seu uso viabiliza pilares de menores dimensões, aumentando assim o espaço útil dos diversos pavimentos, principalmente nos andares mais baixos que normalmente são de garagens. Além disso, permite aumentar a velocidade de execução, reduzir a carga permanente da estrutura e nas fundações e aumentar a durabilidade do concreto. O edifício "Taipei 101 Building", concluído em 2004 na cidade de Taipe (Taiwan), é atualmente o maior arranha-céu do mundo com 508m de altura. Neste edifício foi utilizado concreto com $\mathrm{f}_{\mathrm{ck}}$ igual a 80MPa. Esta mesma resistência foi 
atingida nas torres do "Petronas Towers". No Brasil, a tecnologia tem sido aplicada há pouco tempo e concentrada nos grandes centros. Os projetistas ainda enfrentam alguns obstáculos para especificar o CAD, especialmente em relação ao preço por metro cúbico, a falta de normalização brasileira e a escassez de concreteiras que possuam tecnologia para produzir e manusear o CAD. Mesmo assim, em 1992, em Curitiba foi concluído o "Curitiba Business Center", no qual os pilares foram construídos com CAD com $\mathrm{f}_{\mathrm{ck}}$ igual a 60MPa e, em São Paulo, o edifício "e-Tower Building" bateu o recorde para concreto colorido em 2002 com $\mathrm{f}_{\mathrm{ck}}$ médio de $125 \mathrm{MPa}$ e máximo de $151 \mathrm{MPa}$.
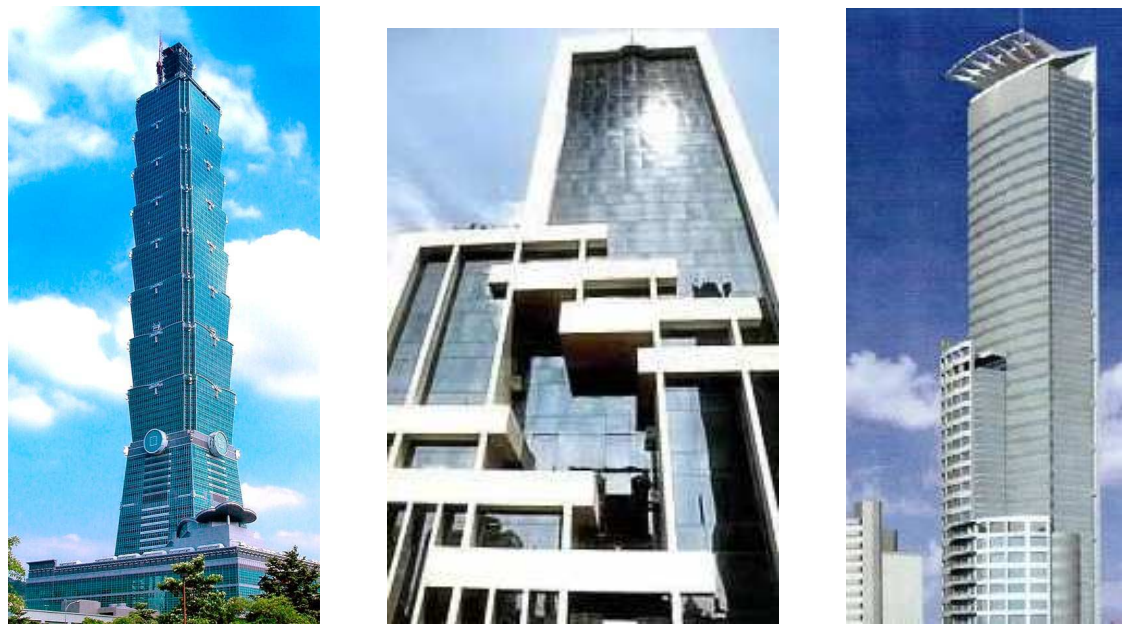

Figura 4: Taipei 101; Curitiba Business Center; e-Tower.

Esta nova era no mundo do concreto deve ser reconhecidamente atribuída à criação de um "novo cimento" ou aglomerante, como explica Liborio (2004). Este material poderia ser constituído de clínquer $\left(\mathrm{C}_{3} \mathrm{~S}, \mathrm{C}_{2} \mathrm{~S}, \mathrm{C}_{3} \mathrm{~A}, \mathrm{C}_{4} \mathrm{AF}\right)$, gipsita (controlador de pega), escória de alto forno, escória de aciaria, cinzas volantes, cinzas de casca de arroz, sílicas ativa (de Fe-Si, da casca do arroz), terras diatomáceas, metacaulinitas, argilas calcinadas, pós de concretos reciclados, cerâmicas moídas, vidros, microfibras, fíler calcário, etc. Liborio esclarece ainda que caberá ao engenheiro projetar as propriedades buscadas: alta resistência, durabilidade a algum agente agressivo (cloretos, dióxido de carbono, sulfatos, partículas abrasivas, fungos, etc), melhoria da 
zona de interface (ligação concreto novo x concreto velho, reparos, continuidade de concretagem), calor de hidratação, resistência ao impacto, resistência à tração, permeabilidade, porosidade, resistividade, tenacidade, baixo módulo de elasticidade, etc.

Outro fator de relevada importância para o desenvolvimento da tecnologia do CAD foi a rápida aceitação em se utilizar a sílica como uma pozolana muito fina e reativa no concreto, como relata Aïtcin (2000).

Silva, I. J. (2000) concluiu em seu trabalho que, para a produção do concreto de elevado desempenho, necessita-se de uma equipe de alto desempenho, ou seja, de pessoal interessado em avanços tecnológicos, qualificado e que assim tenha pleno conhecimento de todos os fatores intervenientes no processo (sabendo que existe um projeto com hipóteses previamente traçadas, um planejamento diferenciado de execução, equipamentos e materiais com qualidade, etc.) controlando-os e adequando-os a cada tipologia da obra.

Para Aïtcin (2003), uma diferença marcante entre um concreto convencional e o de alto desempenho é a presença, neste último, de retração autógena significativa. Esta importante propriedade será comentada na seqüência.

\subsection{CONSIDERAÇÕES GERAIS}

De acordo com a Civil Engineering Research, o CAD difere do concreto convencional pelos seguintes fatores:

- Facilidade de lançamento e compactação;

- $\quad$ Atinge altas resistências em pequenas idades; 
- Apresenta propriedades melhoradas tais como: resistência mecânica a longas idades, resistência à abrasão ou carga de impacto e baixa permeabilidade;

- Apresenta estabilidade de volume e de forma e fissura menos que o concreto convencional;

- É mais durável que o concreto convencional quando sujeito a ataque químico, gelo e degelo ou alta temperatura;

- Apresenta características de durabilidade.

Outras diferenças entre o CAD e o concreto convencional podem ser citadas, algumas delas provêm das acima mencionadas:

- Redução significativa nas dimensões de pilares de edifícios altos, aumentando a área útil dos diversos pavimentos e, principalmente, nos andares mais sobrecarregados e nos de garagem;

- Redução do peso-próprio da estrutura e, conseqüentemente, na carga nas fundações;

- Possível redução na taxa de armaduras dos pilares;

- Maior módulo de elasticidade resultando em deflexões reduzidas e um atraso no início da fissuração;

- Maior rapidez na desforma, o que garante maior velocidade à obra, diminuindo os juros durante a construção;

- Aumento da vida útil da estrutura, devido à baixa porosidade e permeabilidade; 
- Ruptura menos dúctil, o que leva a uma preocupação maior quanto à segurança das estruturas;

- Retração autógena significativa.

Como, geralmente, se utilizam para a fabricação do CAD consumos de cimento superiores aos do comum, a incorporação de aditivos químicos e a utilização de agregados de melhor qualidade, há uma tendência do preço do metro cúbico do produto ser significativamente maior que o do concreto convencional. $\mathrm{O}$ que torna 0 produto viável economicamente é a redução dos elementos, o ganho com o aumento da produtividade, a redução das intervenções para manutenção e reparo e aumento da vida útil. Os subprodutos industriais como a CCA podem contribuir para a diminuição do custo final do CAD, já que atualmente não possuem valor comercial para as empresas e, assim, poderiam ser comercializados a preços bastante competitivos. Além disso, um estudo detalhado de traço do concreto pode otimizar o consumo de cimento e aditivos.

Aïtcin (2003) aponta as alterações volumétricas internas e, conseqüentemente, as exigências de cura do CAD como um dos principais diferenciais em relação aos concretos comuns. A origem destas variações volumétricas tem a mesma causa: o surgimento de forças de tração quer seja pela exsudação (retração plástica), quer pela auto-secagem (retração autógena), quer pela secagem (retração por secagem). O concreto convencional praticamente não apresenta a retração autógena, com ou sem disponibilidade de água proveniente do processo de cura, enquanto o CAD pode sofrer consideravelmente as conseqüências da retração autógena, caso não seja curado adequadamente. A palavra "autógena" significa "gerada de si mesmo". A retração autógena, como o próprio nome diz, é uma retração 
gerada espontaneamente no interior do concreto. Com a continuação da hidratação, com suprimento de água, observam-se variações de volume sem movimento de umidade da ou para a pasta de cimento. A contração é conhecida como retração autógena ou variação autógena de volume e ocorre no interior da massa de concreto. Essa retração é conseqüência da remoção da água dos poros capilares pela hidratação do cimento ainda não hidratado, que é o processo conhecido como auto-secagem. Normalmente a retração autógena é relativamente pequena, exceto com relações águaaglomerante extremamente baixas, como pode acontecer em concretos de alto desempenho, quando passa a ser necessário avaliá-la. Temperaturas mais altas ou teores de cimento maiores também tendem a aumentar a retração autógena.

O CAD deve ser curado imediatamente após o término do seu lançamento, caso contrário irá favorecer a evaporação da água de exsudação, e posteriormente a retração autógena ocorrerá intensamente. Enquanto uma manta impermeável de cura é suficiente para cura do concreto convencional, no qual a retração autógena é insignificante, ela pode prevenir a retração plástica no CAD, mas não consegue inibir a retração autógena. O período crítico de cura para os concretos típicos de alto desempenho é o intervalo entre o término do lançamento até o $2^{\circ}$ ou $3^{\circ}$ dia após o lançamento, sendo que o período entre a $12^{\mathrm{a}}$ a $36^{\mathrm{a}}$ hora posterior ao lançamento merece maior atenção (AÏTCIN, 2003).

\subsection{MICROSCOPIA}

O progresso no campo dos materiais resultou principalmente do reconhecimento do princípio de que as propriedades de um material têm origem na sua 
estrutura interna. O concreto é um material bastante complexo e heterogêneo. Ele é composto por quatro fases: pasta endurecida, agregado, zona de transição e fase vazios. Estas fases não estão igualmente distribuídas na matriz da pasta e nem são uniformes em morfologia e tamanho. Além disso, a estrutura do material influencia em propriedades importantes do concreto como resistência, elasticidade, retração, fluência, fissuração e durabilidade. Por esta razão, conhecer a estrutura interna do concreto é essencial.

A fase agregado é, geralmente, mais resistente do que as demais, logo, não tem influência direta sobre a resistência do concreto, exceto no caso de utilização de agregados altamente porosos, fracos, deletérios e com forma inadequada no concreto, mas estes devem ser evitados ou tratados para serem utilizados em CAD.

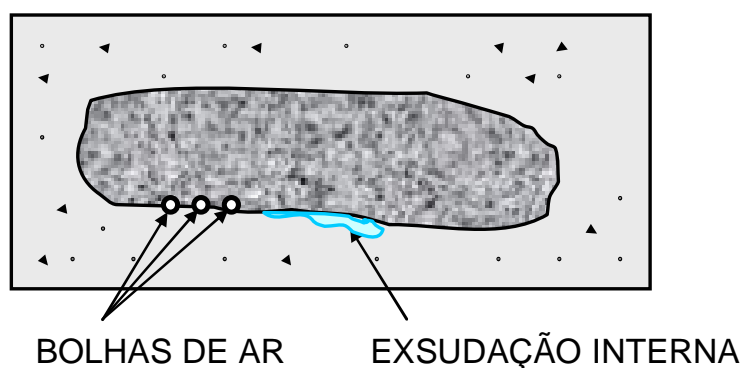

Figura 5: Esquema da exsudação interna num agregado lamelar.

A esfericidade do agregado é importante, partículas eqüidimensionais são mais adequadas. As partículas lamelares e alongadas ${ }^{4}$ têm maior área superficial. Quando um agregado tem elevada relação entre a área superficial e volume, a demanda de água é maior. As partículas lamelares afetam a durabilidade, pois a água de exsudação e as bolhas tendem a se acumular sob elas, conforme pode ser

\footnotetext{
${ }^{4}$ Partícula lamelar é a que tem espessura, a menor dimensão, menor que 0,6 vezes o tamanho médio da peneira da fração de tamanho ao qual pertence; partícula alongada é a que tem comprimento, maior dimensão, maior que 1,8 vezes o tamanho médio da peneira da fração de tamanho ao qual pertence.
} 
observado na Figura 5. Liborio (2004) acrescenta que esta situação pode causar flexão, por exemplo, na partícula rompendo-a com pequenos carregamentos.

A pasta de cimento Portland endurecida é a fase que mais influencia qualitativa e quantitativamente o concreto, como por exemplo pela permeabilidade, resistência mecânica e resistência química. Isto não ocorre somente pelas propriedades da pasta, mas também pela proporção de produtos formados, que a torna mais ou menos densa. Portanto, as propriedades da pasta dependem de aspectos microestruturais como tipo, quantidade e distribuição de sólidos e vazios.

A principal causa das propriedades ligantes entre os produtos de hidratação do cimento Portland e os agregados em uma argamassa ou concreto são as forças de atração de van der Waals. A adesão entre duas superfícies sólidas pode ser atribuída a estas forças de natureza física, sendo o grau de ação aderente dependente da extensão e natureza das superfícies envolvidas (MEHTA e MONTEIRO, 1994). Quanto menor for a partícula, maior será a força de atração.

A pasta é alcalina e, por isso, sua exposição às águas ácidas é prejudicial. Para tanto, é interessante que ela seja a mais impermeável possível. Se assim for, o concreto também será considerado impermeável.

A zona de transição (Z.T.) é a região que existe entre as partículas de agregado e a pasta ou entre pasta e armaduras, pasta e fibras diversas, enfim o encontro entre a pasta e qualquer outro material, estendendo-se o conceito de zona de transição também a junção de superfícies de concreto novo com concreto velho. Apesar de constituída dos mesmos elementos que a pasta, a zona de transição possui estrutura e propriedades diferentes da matriz da pasta. Assim como na matriz da pasta, 
a causa da adesão entre os produtos de hidratação e a partícula de agregado são as forças de Van der Waals.

Mesmo para concretos com baixa relação água-aglomerante, nas primeiras idades, o volume e tamanho de vazios na Z.T. serão maiores que na pasta. Além disso, há grande presença de hidróxido de cálcio $(\mathrm{CH})$, microfissuras e vazios nesta região (Figura 6), e a quebra do empacotamento das partículas de cimento pelo efeito parede. Como conseqüência destes fatores, a zona de transição é, na maioria das vezes, a fase mais fraca em resistência no concreto.

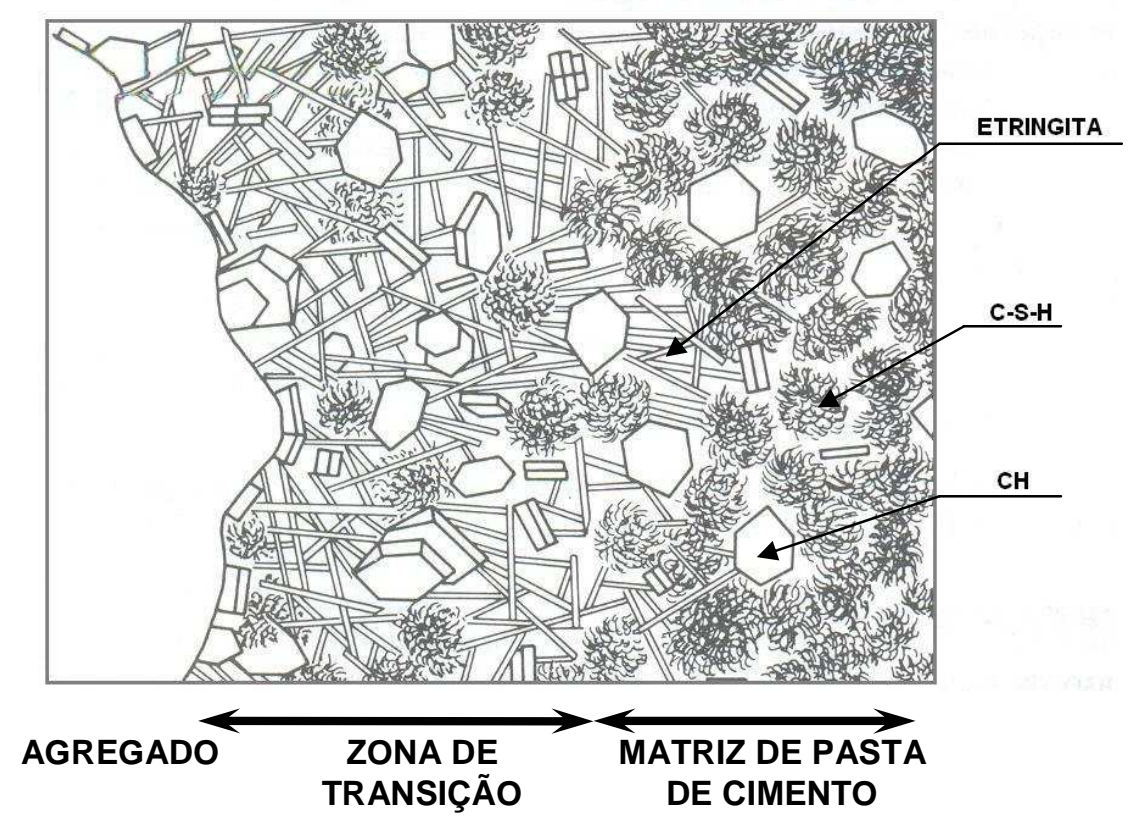

Figura 6: Representação diagramática da Z.T. e da matriz de pasta de cimento no concreto. Fonte: Mehta e Monteiro (1994).

Os cristais de $\mathrm{CH}$ possuem menor área específica (são maiores) e, por isso, menor capacidade de adesão por causa do enfraquecimento das forças de atração de van der Waals e também representam pontos de clivagem preferencial, por conta de sua estrutura orientada. 
As microfissuras na Z.T. podem tanto ser oriundas de forças de tração induzidas por movimentos diferenciais entre o agregado e a pasta, como quando acontece a secagem e esfriamento do concreto. Este mesmo fenômeno também pode se desenvolver em torno da armadura ao invés do agregado em concreto armado.

O efeito parede é o fenômeno que acontece com a inserção de um anteparo numa suspensão de partículas cujo tamanho seja várias vezes menor que do anteparo. Agregados numa pasta de cimento, barras de aço no concreto ou mesmo as formas para peças de argamassa ou concreto são exemplos de anteparos que causam o efeito parede. Com isto há uma quebra do empacotamento das partículas de cimento, ou seja, nas regiões próximas aos anteparos, no caso dos agregados na zona de transição, a distribuição granulométrica das partículas torna-se disforme, como pode ser observado na Figura 7. Este fenômeno é uma das causas da maior quantidade de vazios na Z.T.

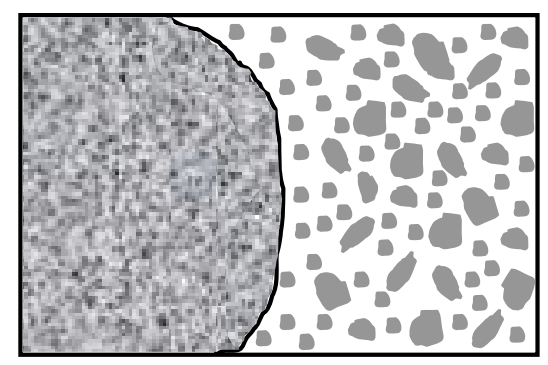

Figura 7: Efeito parede causado por um agregado.

Scrivener (1989) mostra um estudo que revela um decréscimo na porosidade com o aumento da distância da interface pasta-agregado. A porosidade é

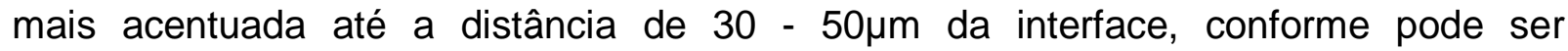
observado na Figura 8. Esta distância coincide com a espessura da Z.T. segundo a autora. 


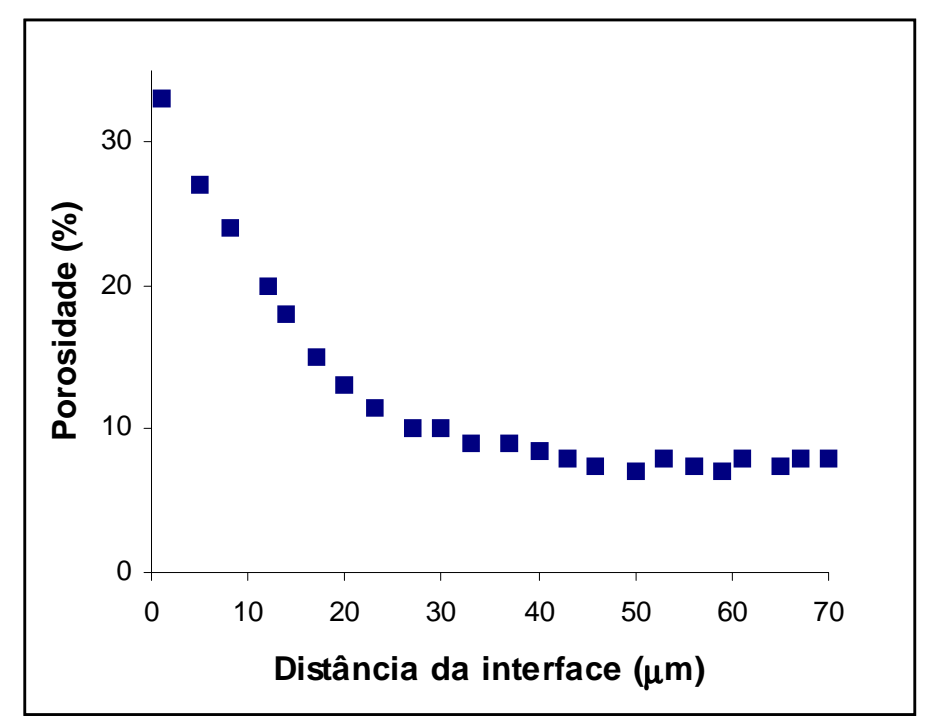

Figura 8: Gráfico distancia da interface x porosidade. Fonte: Scrivener (1989).

A fase vazios é a que compreende os espaços preenchidos por ar aprisionado ou ar incorporado, além dos espaços originalmente não preenchidos pelos produtos de hidratação do cimento e os póros-gel (espaço interlamelar no C-S-H). Esta fase é a principal responsável por propriedades fundamentais do concreto como porosidade e permeabilidade, além de influenciar de forma significativa a resistência mecânica.

O espaço interlamelar no C-S-H é da ordem de $18 \AA ̊$ e, segundo Mehta e Monteiro (1994), é responsável por $28 \%$ da porosidade capilar no C-S-H sólido. Este tamanho de vazio é muito pequeno para ter um efeito desfavorável sobre a resistência e a permeabilidade da pasta. A água, nestes pequenos vazios, é retida por pontes de hidrogênio e a sua remoção, sob determinadas condições (U.R. < 11\%), pode contribuir para a retração por secagem e para a fluência.

Os vazios capilares representam o espaço não preenchido pelos componentes sólidos da pasta e têm forma irregular. $\mathrm{O}$ volume total de uma mistura cimento-água permanece inalterado durante o processo de hidratação, mas a 
densidade média dos produtos de hidratação é consideravelmente menor do que a densidade do cimento Portland anidro. A hidratação do cimento deve ser considerada como um processo durante o qual o espaço inicialmente ocupado pelo cimento e pela água é gradativamente substituído pelo espaço preenchido pelos produtos de hidratação. O espaço não ocupado pelo cimento ou pelos produtos de hidratação constitui-se de vazios capilares. A distância inicial entre as partículas de cimento anidro na pasta de cimento recém misturada (em função da relação a/agl) e o grau de hidratação da pasta determinam o volume e o tamanho dos capilares, os quais apresentam uma significativa influência na permeabilidade da pasta de cimento. Não é a porosidade total, mas a distribuição do tamanho dos poros que controla efetivamente a resistência, a permeabilidade e as variações de volume de uma pasta de cimento endurecida. Os poros grandes, vazios capilares maiores do que 50nm de uma pasta, referidos na literatura (MEHTA e MONTEIRO, 1994) como macroporos, influenciam principalmente a resistência mecânica e a permeabilidade, enquanto os poros pequenos, aqueles vazios menores do que 50nm, referidos como microporos, influenciam mais a retração por secagem e a fluência.

Além das quatro fases mencionadas, outro componente do concreto endurecido é de fundamental importância: a água. Assim com a fase vazios, a água também pode ser encontrada no concreto de várias maneiras. A água pode ser capilar, adsorvida, interlamelar ou quimicamente combinada.

A água capilar é conhecida como a água presente nos vazios maiores do que $5 \mathrm{~nm}(50 \AA ̊)$. Pode ser descrita como o volume de água que está livre da influência das forças de atração exercidas pela superfície sólida (MEHTA e MONTEIRO, 1994). A água capilar pode ser dividida em duas classes de acordo com o tamanho dos vazios 
em que ela se encontra. Se os vazios forem grandes, com diâmetro > 50nm, a água é considerada como água livre e sua remoção não causa qualquer variação de volume. Se o diâmetro for entre $5 \mathrm{~nm}$ a $50 \mathrm{~nm}$, a água é retida por tensão capilar nestes pequenos capilares. A sua remoção, neste caso, pode causar a retração do sistema.

A água adsorvida é aquela que está próxima à superfície do sólido, e cujas moléculas estão física e intimamente aderidas a sua superfície, sob a influência de forças de atração. Ela pode ser perdida por secagem da pasta a $30 \%$ de umidade relativa. A perda dessa água é principalmente responsável pela retração da pasta na secagem (MEHTA e MONTEIRO, 1994; NEVILLE, 1997).

A água interlamelar, também conhecida como água de gel, está associada à estrutura do silicato de cálcio hidratado (C-S-H). A água interlamelar é perdida somente por secagem forte (abaixo de $11 \%$ de umidade relativa). A estrutura do $\mathrm{C}-\mathrm{S}-\mathrm{H}$ retrai-se consideravelmente quando a água interlamelar é perdida (TAYLOR, 1992) porque esta água está fortemente ligada por pontes de hidrogênio.

Água quimicamente combinada, ou água de cristalização, é parte integrante da estrutura de vários produtos hidratados do cimento. Na secagem não é perdida, mas somente liberada, quando os produtos hidratados são decompostos por aquecimento ou quando a pasta de cimento Portland é submetida à ação de congelamento.

A microestrutura do concreto será responsável pela sua resistência mecânica. Num concreto convencional com alta relação água-cimento, como já mencionado, a zona de transição representa o elo fraco da microestrutura. É a partir desta região que o colapso mecânico começa a se desenvolver quando o concreto é submetido a carregamentos. A fissuração da microestrutura prossegue pela matriz da 
pasta, raramente atingindo o interior dos agregados. Isto não é sempre verdadeiro para os concretos de alto desempenho, nos quais é possível minimizar, ou até mesmo eliminar, a zona de transição. A mudança na microestrutura pode ser tão significativa que a ruptura do CAD pode até mesmo acontecer pelo rompimento dos agregados.

\subsection{ASPECTOS DA DURABILIDADE}

A durabilidade de um concreto ganhou maior importância na norma NBR 6118:2003. Como a norma tem caráter de lei no Brasil, fatores que afetam de maneira significativa a durabilidade, como a permeabilidade, a porosidade e a cura do concreto, tornaram-se essenciais em projetos de estruturas de concreto.

A permeabilidade é definida como a facilidade com que um fluido pode escoar através de um sólido. Para o concreto este termo abrange também o transporte de fluidos por difusão ${ }^{5}$ e adsorção. $O$ tamanho e a continuidade dos poros na estrutura do sólido determinam a permeabilidade do concreto. A porosidade da pasta de cimento hidratado é a medida da proporção do volume total do concreto ocupada pelos poros, geralmente expressa em porcentagem (relação sólido/ espaço). A porosidade é determinada conjuntamente pela relação água-aglomerante, grau de hidratação e características do aglomerante.

A permeabilidade tende a ser menor em concretos com relação águaaglomerante menor. Mehta e Monteiro (1994) comentam que as porosidades representadas pelo espaço interlamelar do C-S-H e pequenos capilares não contribuem

\footnotetext{
${ }^{5}$ Difusão: processo pelo qual os íons se misturam, como resultado de seu movimento induzido por agitação térmica, e que, em substâncias dissolvidas, migram de uma região de concentração mais alta a outra de concentração mais baixa.
} 
para a permeabilidade da pasta e que isto se deve, provavelmente, porque o sistema de poros, formado por pequenos poros, tende a tornar-se descontínuo. Os poros importantes para a permeabilidade são aqueles com diâmetro de pelo menos 120 nm ou $160 \mathrm{~nm}$ (NEVILLE; 1997).

A permeabilidade da argamassa ou do concreto é maior que a permeabilidade da pasta de cimento. Isto acontece devido às microfissuras que estão presentes na zona de transição entre o agregado e a pasta de cimento. Durante os períodos iniciais de hidratação, a zona de transição é fraca e vulnerável à fissuração causada por esforços diferenciais entre a pasta do cimento e os agregados, que são induzidos geralmente por retração por secagem, contração térmica e carga aplicada externamente. Uma redução no volume de grandes vazios capilares na matriz da pasta de cimento reduzirá a permeabilidade. Isto pode ser possível usando-se uma baixa relação água-aglomerante, adequado consumo de cimento e condições apropriadas de adensamento e cura. Do mesmo modo, critérios para escolha dos agregados, da granulometria, cuidados especiais para evitar deformações devido à temperatura, retração por secagem e impedimento de carga prematura são estritamente necessários para reduzir o aparecimento de microfissuras na zona de transição. Além destes fatores, a geometria do elemento de concreto, em especial a sua espessura, também se torna importante na medida em que facilita ou dificulta a secagem da peça.

A resistência e a permeabilidade do concreto estão diretamente relacionadas à distribuição do tamanho dos poros e aos tipos de produtos produzidos pela hidratação do cimento e/ou reação das adições minerais. Pastas de cimento hidratadas com grandes quantidades de água são geralmente frágeis e permeáveis, conseqüência de um alto volume de poros capilares grandes, cristais de produtos 
hidratados também grandes (especialmente o hidróxido de cálcio) e microestrutura não homogênea. Assim sendo, para se atenuar a porosidade intrínseca do concreto seriam desejáveis duas ações não necessariamente estanques: a redução da dosagem de água e/ou preenchimento dos vazios.

Tabela 3: Classificação do tamanho dos poros na pasta de cimento endurecida. Fonte: Silva, I. J. (2000)

\begin{tabular}{|c|c|c|c|c|}
\hline TERMINOLOGIA & DIÂMETRO & $\begin{array}{c}\text { DESCRIÇÃO } \\
\text { (nome do poro } \\
\text { correspondente) }\end{array}$ & $\begin{array}{c}\text { FUNÇÃO DA } \\
\text { ÁGUA }\end{array}$ & $\begin{array}{l}\text { PROPRIEDADES } \\
\text { AFETADAS }\end{array}$ \\
\hline MACROPOROS & $1000 \mu \mathrm{m}-15 \mu \mathrm{m}$ & Vazios grandes & $\begin{array}{l}\text { Comporta-se } \\
\text { como água } \\
\text { livre }\end{array}$ & $\begin{array}{l}\text { Resistência e } \\
\text { permeabilidade }\end{array}$ \\
\hline \multirow{2}{*}{$\begin{array}{c}\text { POROS } \\
\text { CAPILARES }\end{array}$} & $15 \mu \mathrm{m}-0,05 \mu \mathrm{m}$ & Capilares grandes & $\begin{array}{l}\text { Comporta-se } \\
\text { como água } \\
\text { livre }\end{array}$ & $\begin{array}{c}\text { Resistência e } \\
\text { permeabilidade }\end{array}$ \\
\hline & $50 n m-10 n m$ & $\begin{array}{l}\text { Capilares médios, } \\
\text { cavidade capilar, poros } \\
\text { entre partículas de gel }\end{array}$ & $\begin{array}{l}\text { Provoca } \\
\text { moderadas } \\
\text { tensões } \\
\text { superficiais }\end{array}$ & $\begin{array}{l}\text { Resistência e } \\
\text { permeabilidade; } \\
\text { retração e } \\
\text { umidade elevada }\end{array}$ \\
\hline \multirow{3}{*}{$\begin{array}{l}\text { POROS DE } \\
\text { GEL }\end{array}$} & $10 \mathrm{~nm}-2,5 \mathrm{~nm}$ & Poros de gel & $\begin{array}{c}\text { Provoca } \\
\text { fortes tensões } \\
\text { superficiais }\end{array}$ & $\begin{array}{l}\text { Retração até } \\
50 \% \text { de U.R. }\end{array}$ \\
\hline & $2,5 \mathrm{~nm}-0,5 \mathrm{~nm}$ & $\begin{array}{l}\text { Microporos, poros de } \\
\text { gel, poros inter- } \\
\text { cristalinos }\end{array}$ & $\begin{array}{l}\text { Agua } \\
\text { fortemente } \\
\text { adsorvida; } \\
\text { não forma } \\
\text { menisco }\end{array}$ & $\begin{array}{l}\text { Retração e } \\
\text { deformação } \\
\text { lenta }\end{array}$ \\
\hline & $<0,5 \mathrm{~nm}$ & $\begin{array}{c}\text { Microporos } \\
\text { "interlamelares", } \\
\text { espaços } \\
\text { "interlamelares", poros } \\
\text { inter-cristalinos }\end{array}$ & $\begin{array}{c}\text { Água } \\
\text { estrutural } \\
\text { envolvida nas } \\
\text { ligações }\end{array}$ & $\begin{array}{l}\text { Retração e } \\
\text { deformação } \\
\text { lenta }\end{array}$ \\
\hline
\end{tabular}

Rössler e Odler ${ }^{6}$ apud Silva, I. J. (2000) estabeleceram uma relação linear entre a resistência e a porosidade dentro do intervalo entre $5 \%$ a $28 \%$. Observaram que os poros menores que $20 \eta \mathrm{m}$ apresentam efeitos desprezíveis na resistência. Além da porosidade total, deve ser considerado o efeito da distribuição dos tamanhos de poros sobre a resistência (Tabela 3). Para Mehta e Monteiro (1994) os poros grandes

\footnotetext{
${ }^{6}$ RÖSSLER, M. e ODLER, I. (1985). Investigations on the relationship between porosity, structure and strength of hydrated Portland cement pastes. I - Effect of porosity, Cement and Concrete Research, v.15, n.2, p.320-330.
} 
influenciariam a resistência à compressão e a permeabilidade, enquanto que os pequenos afetariam mais a fluência e a retração por secagem.

Comparado à porosidade capilar de $30 \%$ a $40 \%$ de pastas típicas de cimento em concreto endurecido, o volume de poros na maioria dos agregados naturais está normalmente abaixo de $3 \%$ e raramente excede a $10 \%$. Sendo assim o coeficiente de permeabilidade do agregado é bem menor que o da pasta de cimento típica (MEHTA e MONTEIRO; 1994).

O concreto é potencialmente vulnerável a diversas ações tais como: gelo, ataque por sulfato, reação álcali-agregado e corrosão do aço. Cada um destes processos envolve movimento de água ou outros fluidos, transportando agentes agressivos através da estrutura porosa do concreto. Portanto, a porosidade e a permeabilidade são propriedades importantes que afetam a durabilidade do concreto e, conseqüentemente, impermeabilidade é uma das propriedades essenciais em concretos que se espera um alto desempenho.

Com a evolução da hidratação, a permeabilidade decresce rapidamente porque o volume total do gel, é igual a cerca de 2,1 vezes o volume do cimento não hidratado, de modo que, progressivamente, o gel preenche parte do espaço inicialmente ocupado pela água. Os poros vão se reduzindo e perdendo suas interconexões, é deste modo que a permeabilidade diminui. Diante deste fato, a cura se torna um procedimento de fundamental importância para se diminuir a porosidade e, conseqüentemente, a permeabilidade do concreto. Simulações neste sentido foram realizadas por Bentz e Garboczi (1992) na qual determinou-se o grau de hidratação necessário de pastas para se atingir uma desconexão de poros. O resultado obtido está apresentado na Tabela 4. Nota-se pela tabela que a adição de sílicas ativas promove a 
descontinuidade dos poros a idades menores. Por exemplo, para uma relação águaaglomerante igual a 0,400 sem adição de sílica (0\%) será necessário que $66 \%$ da hidratação tenha ocorrido para que os poros estejam desconectados, enquanto que com adição de $10 \%$ de sílica ativa, este valor é reduzido para $48 \%$.

Tabela 4: Grau de hidratação necessário para se conseguir a descontinuidade dos poros para várias relações água-aglomerante e \% de sílica ativa.

Fonte: Bentz e Garboczi (1992).

\begin{tabular}{|c|c|c|c|c|c|c|c|c|c|c|}
\hline \multirow{2}{*}{$\begin{array}{c}\text { Relação } \\
\text { a/agl }\end{array}$} & \multicolumn{10}{|c|}{ Quantidade de sílica ativa (\%) } \\
\hline & 0 & 2,5 & 5 & 7,5 & 10 & 12,5 & 15 & 20 & 25 & 30 \\
\hline 0,225 & 0,31 & 027 & 0,23 & 0,22 & 0,22 & 0,22 & 0,21 & 0,20 & 0,20 & 0,19 \\
\hline 0,250 & 0,36 & 0,32 & 0,27 & 0,26 & 0,26 & 0,25 & 0,25 & 0,24 & 0,24 & 0,23 \\
\hline 0,275 & 0,41 & 0,37 & 0,32 & 0,30 & 0,29 & 0,29 & 0,29 & 0,28 & 0,27 & 0,26 \\
\hline 0,300 & 0,46 & 0,42 & 0,37 & 0,33 & 0,33 & 0,32 & 0,32 & 0,32 & 0,31 & 0,30 \\
\hline 0,325 & 0,51 & 0,47 & 0,42 & 0,37 & 0,37 & 0,36 & 0,36 & 0,35 & 0,35 & 0,34 \\
\hline 0,350 & 0,56 & 0,52 & 0,47 & 0,42 & 0,41 & 0,40 & 0,40 & 0,39 & 0,38 & 0,38 \\
\hline 0,375 & 0,61 & 0,57 & 0,52 & 0,47 & 0,44 & 0,44 & 0,44 & 0,43 & 0,42 & 041 \\
\hline 0,400 & 0,66 & 0,62 & 0,57 & 0,52 & 0,48 & 0,47 & 0,47 & 0,47 & 0,46 & 0,45 \\
\hline 0,425 & 0,71 & 0,67 & 0,62 & 0,57 & 0,53 & 0,51 & 0,51 & 0,50 & 0,50 & 0,49 \\
\hline 0,450 & 0,76 & 0,72 & 0,67 & 0,62 & 0,58 & 0,55 & 0,55 & 0,54 & 0,53 & 0,53 \\
\hline 0,475 & 0,81 & 0,77 & 0,72 & 0,67 & 0,63 & 0,59 & 0,59 & 0,58 & 0,57 & 0,56 \\
\hline 0,500 & 0,86 & 0,82 & 0,77 & 0,72 & 0,68 & 0,63 & 0,62 & 0,62 & 0,61 & 0,60 \\
\hline 0,525 & 0,91 & 0,87 & 0,82 & 0,77 & 0,73 & 0,68 & 0,66 & 0,65 & 0,65 & 0,64 \\
\hline 0,550 & 0,96 & 0,92 & 0,87 & 0,82 & 0,78 & 0,73 & 0,70 & 0,69 & 0,68 & 0,68 \\
\hline 0,600 & --- & -- & 0,97 & 0,92 & 0,88 & 0,83 & 0,78 & 0,76 & 0,76 & 0,75 \\
\hline 0,650 & -- & $--\cdot$ & -- & -- & 0,98 & 0,93 & 0,88 & 0,84 & 0,83 & 0,82 \\
\hline 0,700 & --- & -- & --- & -- & -- & --- & 0,98 & 0,91 & 0,91 & 0,90 \\
\hline
\end{tabular}

Liborio (2004) comenta que a não existência da cura poderá propiciar uma hidratação inadequada do cimento, com ausência do refinamento dos poros. Também poderá ocasionar auto-dessecação, causando retração com fissuração visível e que pode comprometer o elemento estrutural. O processo de cura interfere na quantidade e distribuição de poros no concreto e promove grandes perturbações na microestrutura do concreto.

Em relação à resistência mecânica, para Aïtcin e Neville (2003) não é a porosidade a propriedade que mais afeta o concreto, e sim a aderência entre as partículas da matriz. A causa de misturas com altas relações água-aglomerante terem resistências menores consiste no fato de estas misturas terem mais dificuldade em 
desenvolver a aderência. Isto ocorre porque a extensão entre as superfícies dos produtos de hidratação torna-se maior e, conseqüentemente, torna-se mais difícil a criação de novos produtos intermediários. Misturas porosas significam aderência mais fraca pelo mesmo motivo de misturas com altas relações água-aglomerante. Segundo os autores, esta é, na realidade, a causa da porosidade influenciar a resistência de maneira tão significativa.

Com a tecnologia do CAD é necessária uma revisão da evolução das leis propostas por Féret e Abrams para o comportamento mecânico, além da estrutura química e da reologia do concreto, de modo a estabelecer as diferenças entre os concretos convencionais e o de alto desempenho. Ferét, em 1892, foi o responsável pela primeira formulação entre força de compressão e os componentes não sólidos do concreto. Ele entendeu que a presença de água e vazios na argamassa era uma influência negativa na resistência. De acordo com Féret, a resistência é inversamente proporcional ao quadrado da relação água-cimento. Já para Abrams, em 1925, a relação entre resistência e fator água-cimento é exponencial. Ambas as formulações são muito importantes, mas devem ser usadas com cuidado no caso de concretos de alto desempenho principalmente porque os cimentos modernos são muito diferentes dos utilizados por eles e, além disso, os CAD geralmente contêm componentes adicionais como, por exemplo, os superplastificantes. Foi na metade do século XX que Powers e seus colaboradores estabeleceram dados quantitativos sobre a água envolvida na hidratação do cimento e sobre os volumes de cimento, água e produtos da hidratação (AÏTCIN e NEVILLE; 2003). Eles chegaram à conclusão que para que uma mistura se hidratar completamente, a relação água-cimento deve ser de no mínimo 0,42 . Isto ocorre porque o mínimo de massa de água necessária para a completa 
hidratação é duas vezes a massa requerida estequiometricamente para a formação de C-S-H.

Esta interpretação sob novos pontos de vistas, levando-se em conta principalmente o aprimoramento das técnicas de produção de cimento, materiais alternativos, além do emprego de aditivos que permitem grande mobilidade para projetar concretos de acordo com as adversidades a serem enfrentadas, quer seja pela agressividade do ambiente, ou pela proposta arquitetônica, ou pela dificuldade de execução (acesso, lançamento, tempo, etc) formará o real conceito do CAD e esclarecerá suas peculiaridades (LIMA, S. M.; 2006). 


\section{MATERIAIS COMPONENTES DO CAD}

A escolha dos materiais componentes é outro fator fundamental para a produção de CAD. Segundo Aïtcin (2000), a melhor maneira de garantir a seleção adequada dos materiais para o CAD é por intermédio de estudos experimentais em laboratório.

\subsection{CIMENTO PORTLAND}

Segundo a ABCP (Associação Brasileira de Cimento Portland), cimento pode ser definido como um pó fino, com propriedades aglomerantes, aglutinantes ou ligantes, que endurece sob a ação de água. Na forma de concreto, torna-se uma pedra artificial, que pode ganhar formas e volumes diversos, de acordo com as necessidades de cada projeto. Graças a essas características, o concreto é o segundo material mais consumido pela humanidade, superado apenas pela água.

A palavra "cimento" é originada do latim "caementu", que designava na velha Roma espécie de pedra natural de rochedos e não esquadrejada. A origem do cimento data de 4500 anos atrás. Os monumentos do Egito antigo já utilizavam uma liga constituída por uma mistura de gesso calcinado. As grandes obras gregas e romanas, como o Panteão e o Coliseu, foram construídas com o uso de solos de origem vulcânica da ilha grega de Santorino ou das proximidades da cidade italiana de Pozzuoli, que possuíam propriedades de endurecimento sob a ação da água. O grande passo no desenvolvimento do cimento foi dado em 1756 pelo inglês John Smeaton, que conseguiu obter um produto de alta resistência por meio de calcinação de calcários 
moles e argilosos. Em 1818, o francês Vicat obteve resultados semelhantes aos de Smeaton, pela mistura de componentes argilosos e calcários. Smeaton é considerado o inventor do cimento artificial. Em 1824, o construtor inglês Joseph Aspdin queimou conjuntamente pedras calcárias e argila, transformando-as num pó fino. Percebeu que obtinha uma mistura que, após secar, tornava-se tão dura quanto as pedras empregadas nas construções. A mistura não se dissolvia em água e foi patenteada pelo construtor no mesmo ano, com o nome de cimento Portland, que recebeu esse nome por apresentar cor e propriedades de durabilidade e solidez semelhantes às rochas da ilha britânica de Portland (BATTAGIN, A. F.; 2004).

O cimento Portland comum é um aglomerante hidráulico ${ }^{7}$ produto da moagem do clínquer obtido pela calcinação e clinquerização da mistura de proporções adequadas de calcário e argila. Nessa moagem, é adicionado um teor de 3\% a 4\% de gipsita (sulfato de cálcio), em geral, em uma ou mais formas de sulfato de cálcio, para controlar o tempo de pega do cimento que seria demasiadamente rápida.

O processo de fabricação do cimento inicia pela extração do calcário e da argila de minas. O calcário é, então, levado para a britagem, quando se reduz o tamanho das pedras. O minério é depositado na fábrica ainda em forma de brita. A argila empregada deve ser constituída essencialmente de silicato de alumínio, geralmente contendo ferro e outros óxidos minerais em menor porcentagem. Estas matérias-primas passam então por um processo de mistura (pré-homogeneização). Esta etapa é importante para garantir a qualidade da dosagem do produto $(90 \%$ de calcário e $10 \%$ de $\left.\operatorname{argila}^{8}\right)$. Esta mistura é levada para ser moída em moinhos horizontais de bolas, compostos por esferas de aço, que transformam o material num

\footnotetext{
${ }^{7}$ Aglomerantes hidráulicos são aqueles que só endurecem pela reação com a água e formam um produto resistente à água.

${ }^{8}$ Dado obtido no catálogo da "Cimento Rio Branco S/A" da empresa Votorantin (2001).
} 
pó finíssimo (farinha crua). A farinha crua moída é então armazenada em silos de homogeneização, que prepara o material para a próxima etapa, na qual a farinha passará por um processo de transformação química. Após a homogeneização completa, o material sofre um processo de pré-aquecimento, na chamada torre de ciclones, que fica na estrutura superior do forno. A clinquerização da farinha ocorre a uma temperatura de $1450^{\circ} \mathrm{C}$. O clínquer é um composto granulado, escuro, fosco, com propriedades hidráulicas (Figura 9).

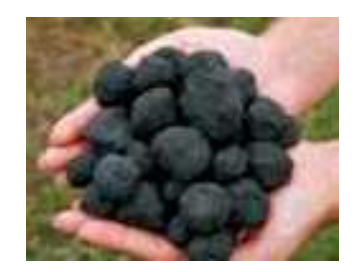

Figura 9: Clínquer.

Fonte: <http://www.abcp.org.br> (acesso em 18/07/2005).

Do ponto de vista da composição, o clínquer do cimento Portland sai do forno como uma mistura de duas fases de silicatos bem cristalizados, silicatos tricálcico $\left(\mathrm{C}_{3} \mathrm{~S}\right)$, ou ainda alita, e silicatos dicálcico $\left(\mathrm{C}_{2} \mathrm{~S}\right)$, também chamado de belita, e uma fase intersticial composta de fase aluminato $\left(C_{3} A\right)$ e fase ferrita $\left(C_{4} A F\right)$, mais ou menos cristalizada. Além destas fases, também podem ser encontradas poucas impurezas como o periclásio $(\mathrm{MgO})$, óxido de cálcio endurecido $(\mathrm{CaO})$ e sulfatos alcalinos. Segundo Aïtcin (2000), a adição de $\mathrm{Al}_{2} \mathrm{O}_{3}$ (aluminato) e do $\mathrm{Fe}_{2} \mathrm{O}_{3}$ (ferro-aluminato) reduz a temperatura de calcinação das matérias-primas durante sua transformação em clínquer, criando duas fases (aluminato e ferroaluminato) que se fundem para formação do $\mathrm{C}_{3} \mathrm{~S}$, permitindo ainda que os íons $\mathrm{Ca}^{++}$difundam-se mais rápido transformando o $\mathrm{C}_{2} \mathrm{~S}$ previamente formado em $\mathrm{C}_{3} \mathrm{~S}$. Após sua formação dentro dos fornos, ainda segundo o mesmo autor, é feito um resfriamento brusco até cerca de $150^{\circ} \mathrm{C}$, que é necessário para que os cristais dos compostos formados permaneçam de forma 
desordenada e, portanto, reativos com a água. O resfriamento rápido solidifica as diferentes fases nas suas formas à alta temperatura, não permitindo que elas sigam sua natural transformação de fase, que teria ocorrido sob o resfriamento lento. Depois de resfriado, o clínquer será moído e sofrerá adições (gesso, fíler, cinza pozolânica, escória, etc.) para formar os diferentes tipos de cimentos. A Figura 10 expõe as várias etapas do processo de fabricação do cimento.

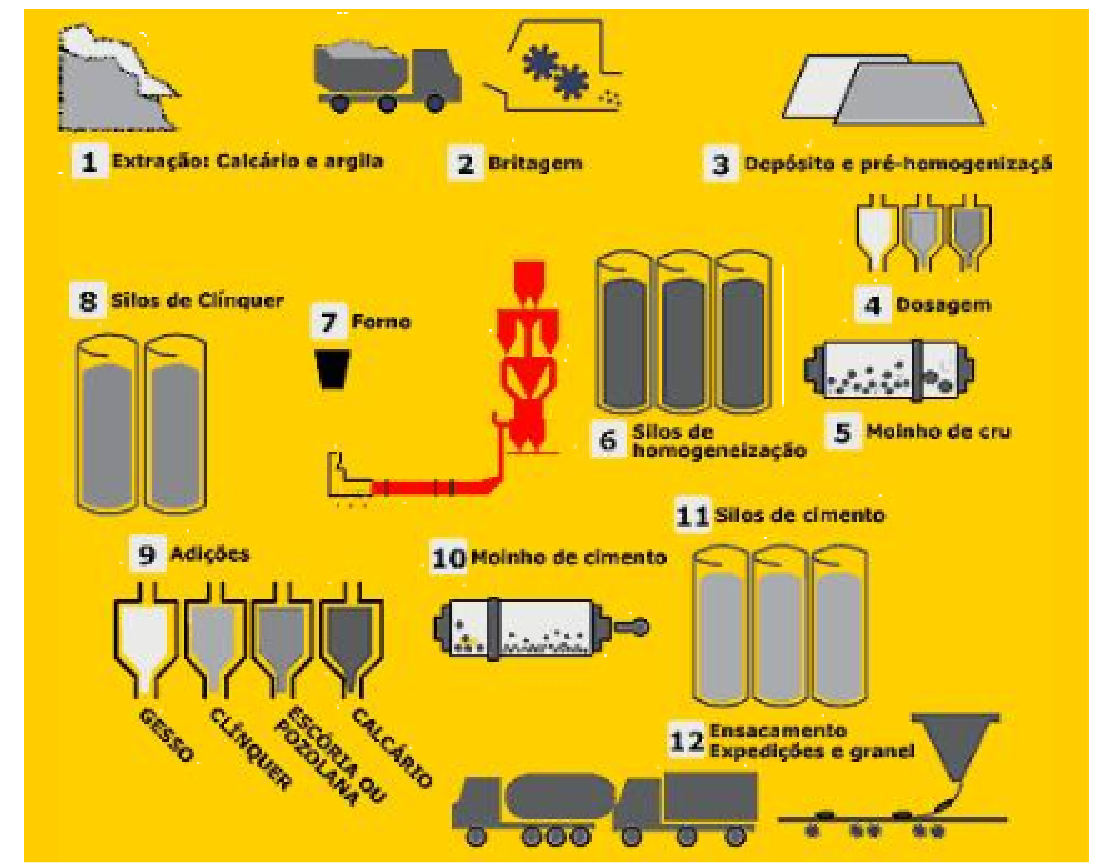

Figura 10: Processo de fabricação do cimento Portland Fonte: <http://www.abcp.org.br> (acesso em 28/07/2005).

Os elementos que compõem o cimento Portland consistem principalmente de calcário, sílica, alumina e óxido de ferro. A Tabela 5 mostra os limites usuais da proporção destes óxidos componentes do cimento Portland. A composição real varia consideravelmente entre os vários tipos de cimento e influi nas propriedades finais do produto. Os óxidos secundários existentes nas matérias-primas são o $\mathrm{MgO}, \mathrm{TiO}_{2}$, $\mathrm{MnO}_{2}, \mathrm{~K}_{2} \mathrm{O}$ e $\mathrm{Na}_{2} \mathrm{O}$. O $\mathrm{K}_{2} \mathrm{O}$ e o $\mathrm{Na}_{2} \mathrm{O}$, conhecidos como álcalis, são óxidos que podem 
reagir com alguns agregados (rochas ácidas) de modo que, desta reação, resultam produtos expansivos que provocam a disgregação do concreto.

Tabela 5: Óxidos oriundos das matérias-primas do cimento Portland.

\begin{tabular}{|c|c|c|c|}
\hline COMPONENTE & ABREVIATURA & $\%$ & ORIGEM \\
\hline $\mathrm{CaO}$ & $\mathbf{C}$ & $61-67$ & Calcário \\
\hline $\mathrm{SiO}_{2}$ & $\mathbf{S}$ & $20-23$ & Argila \\
\hline $\mathrm{Al}_{2} \mathrm{O}_{3}$ & $\mathbf{A}$ & $2-3,5$ & Argila \\
\hline $\mathrm{Fe}_{2} \mathrm{O}_{3}$ & $\mathbf{F}$ & $4,5-7,0$ & Argila \\
\hline MgO & & $0,8-6$ & Dolomita (calcário) \\
\hline $\mathrm{SO}_{3}$ & & $1-2,3$ & Gipsita \\
\hline Álcalis & $\mathrm{K}_{2} \mathrm{O}$ e $\mathrm{Na}_{2} \mathrm{O}$ & $0,3-1,5$ & Argila \\
\hline
\end{tabular}

Os óxidos componentes do cimento interagem entre si dentro do forno formando elementos mais complexos e, com exceção de um pequeno resíduo de cal que não terá tempo suficiente para reagir, é atingido um estado de equilíbrio químico (NEVILLE, 1997). Os principais compostos são os silicatos tricálcico e dicálcico, o aluminato tricálcico e o ferroaluminato tetracálcico, citados anteriormente e expostos na Tabela 6.

Tabela 6: Principais compostos constituintes do cimento Portland Fonte: Armelin et al ${ }^{9}$ apud Costenaro (2003).

\begin{tabular}{|c|c|c|c|}
\hline COMPOSIÇÃO & CONSTITUIÇÃO & SÍMBOLO & PROPRIEDADES TECNOLÓGICAS \\
\hline $\begin{array}{l}\text { Silicato tricálcico } \\
\text { (alita) }\end{array}$ & $3 \mathrm{CaO} . \mathrm{SiO}_{2}$ & $\mathrm{C}_{3} \mathrm{~S}$ & $\begin{array}{l}\text { Endurecimento rápido } \\
\text { Alto calor de hidratação } \\
\text { Alta resistência inicial. }\end{array}$ \\
\hline $\begin{array}{c}\beta-\text { Silicato dicálcico } \\
\text { (belita) }\end{array}$ & $2 \mathrm{CaO} . \mathrm{SiO}_{2}$ & $\mathrm{C}_{2} \mathrm{~S}$ & $\begin{array}{l}\text { Endurecimento lento } \\
\text { Baixo calor de hidratação } \\
\text { Baixa resistência inicial }\end{array}$ \\
\hline Aluminato tricálcico & $3 \mathrm{CaO} . \mathrm{Al}_{2} \mathrm{O}_{3}$ & $\mathrm{C}_{3} \mathrm{~A}$ & $\begin{array}{l}\text { Pega muito rápida, suscetibilidade } \\
\text { ao ataque em meios sulfatados, alto } \\
\text { calor de hidratação, alta retração e } \\
\text { baixa resistência inicial. }\end{array}$ \\
\hline $\begin{array}{l}\text { Ferroaluminato } \\
\text { tetracálcico }\end{array}$ & $4 \mathrm{CaO} . \mathrm{Al}_{2} \mathrm{O}_{3} . \mathrm{Fe}_{2} \mathrm{O}_{3}$ & $\mathrm{C}_{4} \mathrm{AF}$ & $\begin{array}{c}\text { Endurecimento lento } \\
\text { Resistência a meio sulfatados } \\
\text { Pouca contribuição para a } \\
\text { resistência }\end{array}$ \\
\hline Cal livre & $\mathrm{CaO}$ & C & $\begin{array}{l}\text { Aceitável em pequenas quantidades. } \\
\text { Altos teores causam expansão e } \\
\text { fissuração. }\end{array}$ \\
\hline
\end{tabular}

\footnotetext{
${ }^{9}$ ARMELIN, H.; ISAIA, G. C.; LIMA, M. G. (1991). Influência dos aditivos na hidratação das pastas de cimento portland. Seminário apresentado à Escola Politécnica da USP no curso de pós-graduação em Engenharia de Construção Civil e Urbana. São Paulo.
} 
Segundo Neville (1997), o silicato tricálcico $\left(C_{3} S\right)$ é normalmente preponderante (50 a 70\%) e aparece como pequenos grãos eqüidimensionais incolores. Sua composição é incerta e a relação $C / S^{10}$ varia entre 1,7 e 2,0 (SCRIVENER; 1989). O silicato tricálcico é um gel impuro responsável pela resistência nos primeiros dias de idade da pasta. Os cimentos de alta resistência inicial (ARI) são ricos em $\mathrm{C}_{3} \mathrm{~S}$.

O silicato dicálcico $\left(\mathrm{C}_{2} \mathrm{~S}\right)$ pode ter três, ou até quatro, formas e representa de 15 a $30 \%$ do clínquer. $\mathrm{O} \alpha-\mathrm{C}_{2} \mathrm{~S}$, que existe em temperaturas elevadas, se transforma na forma $\beta$ a cerca de $1450^{\circ} \mathrm{C}$. $O \beta-\mathrm{C}_{2} \mathrm{~S}$ sofre outra transformação para $\gamma-\mathrm{C}_{2} \mathrm{~S}$ a cerca de $670^{\circ} \mathrm{C}$. Entretanto, por causa da velocidade de resfriamento dos cimentos comerciais, o $\beta-C_{2} S$ se mantém no clínquer como grãos arredondados, geralmente geminados, razão porque o $\mathrm{C}_{2} \mathrm{~S}$ é também conhecido como belita. Pastas com $\mathrm{C}_{2} \mathrm{~S}$ endurecem lentamente nos primeiros 28 dias oferecendo, mesmo no final deste período, pouca resistência. Entretanto, depois deste período, a resistência aumenta rapidamente e em 1 ano alcança a resistência do $C_{3} S$. Este fato se deve à estrutura muito mais compacta do $\mathrm{C}_{2} \mathrm{~S}$ comparada à do $\mathrm{C}_{3} \mathrm{~S}$.

O aluminato tricálcico $\left(\mathrm{C}_{3} \mathrm{~A}\right)$ constitui aproximadamente 5 a $10 \%$ do clínquer do cimento Portland. Este produto forma cristais retangulares e possui pega quase instantânea, intensidade rápida de reação com grande produção de calor. Em relação à resistência mecânica, possui pouca importância e também não é resistente à ação de águas agressivas.

O ferroaluminato tetracálcico $\left(\mathrm{C}_{4} \mathrm{AF}\right)$, ou fase ferrita, é na verdade a simplificação de uma solução sólida, cuja composição varia entre $C_{2} F$ e $C_{6} A_{2} F$, tem pega em poucos minutos, mas não instantânea. Sua resistência é ligeiramente inferior a

\footnotetext{
${ }^{10}$ Relação C/S $=\mathrm{CaO} / \mathrm{SiO}_{2}$
} 
do $\mathrm{C}_{3} \mathrm{~A}$. A Tabela 7 traz um resumo do efeito dos compostos principais do cimento Portland em relação à resistência, intensidade de reação e calor desenvolvido.

Tabela 7: Efeito dos compostos do cimento Portland.

\begin{tabular}{ccccc}
\hline PROPRIEDADE & $\mathrm{C}_{3} \mathrm{~S}$ & $\mathrm{C}_{2} \mathrm{~S}$ & $\mathrm{C}_{3} \mathrm{~A}$ & $\mathrm{C}_{4} \mathrm{AF}$ \\
\hline Resistência & BOA & BOA & FRACA & FRACA \\
\hline Intensidade da reação & MEDIA & LENTA & RAPIDA & RAPIDA \\
\hline Calor desenvolvido & MEDIO & PEQUENO & GRANDE & PEQUENO \\
\hline
\end{tabular}

$\mathrm{Na}$ presença de água, os silicatos e aluminatos formam produtos de hidratação que, com o passar do tempo, dão origem à estrutura da pasta de cimento endurecida. $\mathrm{O}$ estudo da microestrutura de pastas de cimentos hidratadas apresenta uma agregação de produtos pouco cristalinos, principalmente silicato de cálcio hidratado (C-S-H), cristais de etringita (AFt), grandes cristais de hidróxidos de cálcio $(\mathrm{CH})$, algumas partículas de clínquer não hidratadas, bulbos ocasionados por ar aprisionado e vazios capilares de vários tamanhos e formas (MEHTA e MONTEIRO,1994).

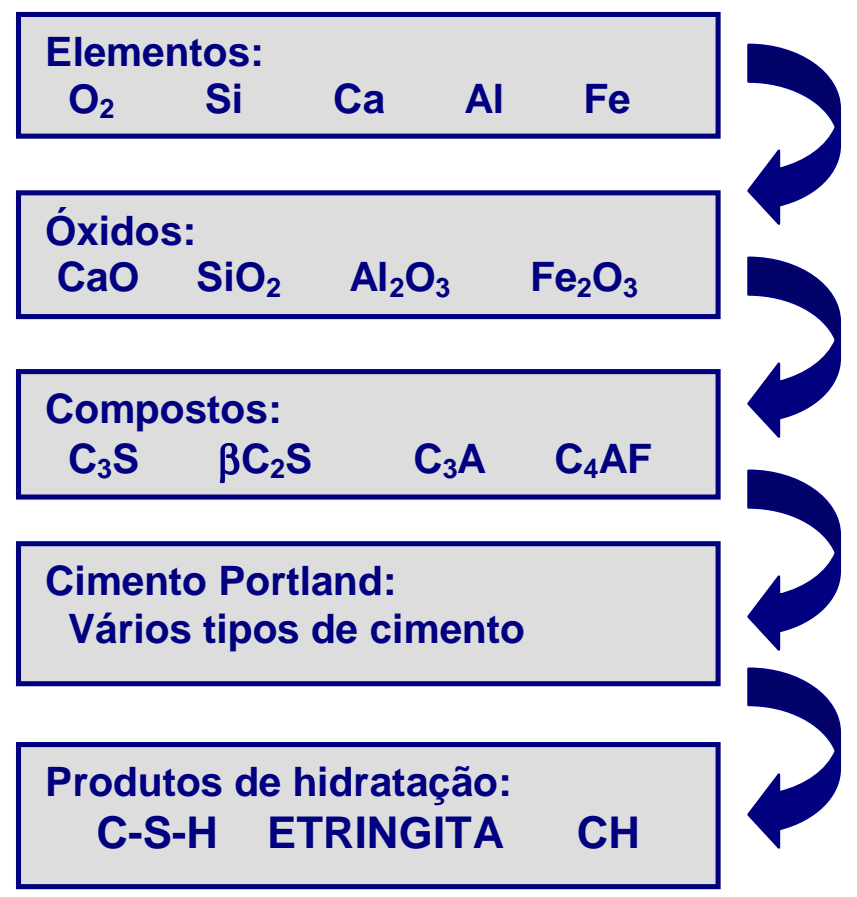

Figura 11: Representação esquemática da formação e hidratação do cimento Portland. 

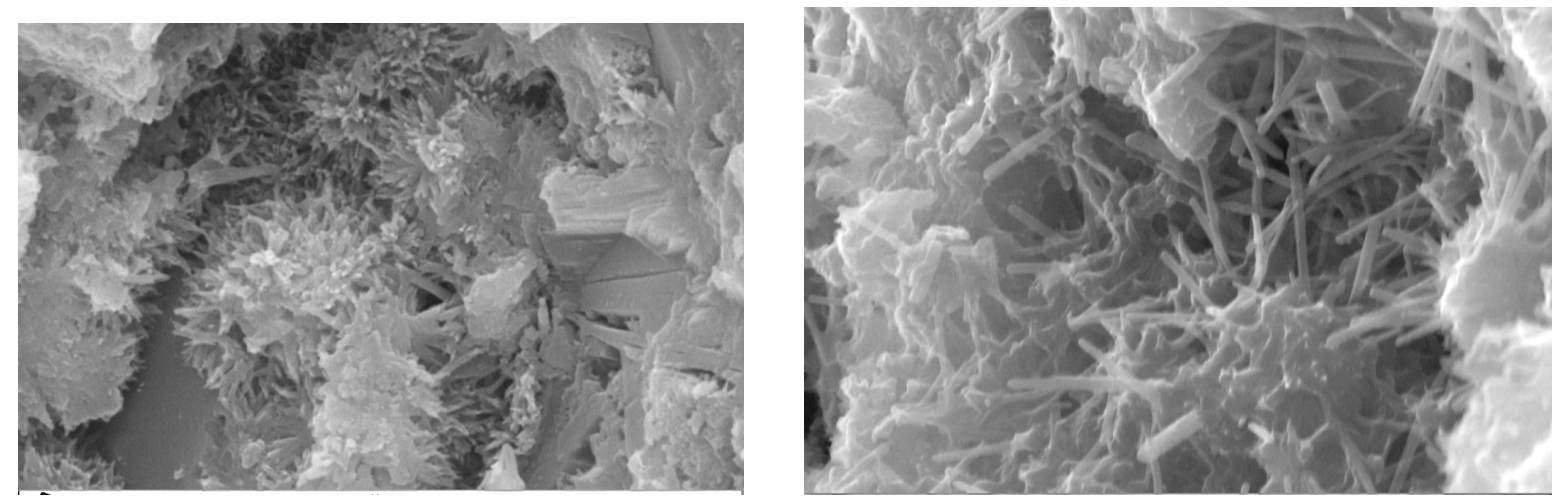

Figura 12: MEV 20.000x e 35.000x - Silicato de cálcio hidratado (C-S-H).

Fonte: Melo (2000).

O produto silicato de cálcio hidratado (Figura 12) constitui de 50 a $60 \%$ do volume de sólidos de uma pasta de cimento Portland completamente hidratada. A morfologia do C-S-H varia de fibras pouco cristalinas a um reticulado cristalino (MEHTA e MONTEIRO, 1994). De acordo com Costenaro (2003), existem quatro tipos de C-S-H. São eles:

- C-S-H tipo I: é encontrado principalmente nas primeiras idades. É formado por partículas que se lançam para fora dos grãos de cimento;

- C-S-H tipo II: ocorre em conjunto com o C-S-H tipo I. Sua estrutura é conhecida como reticular ou favo de mel;

- C-S-H tipo III: é uma massa compacta e homogênea bem comum nas pastas de cimento endurecidas e parece constituir uma boa parcela dos produtos hidratados totais. É um material com morfologia difícil de ser definida;

- C-S-H tipo IV: é o material característico da camada interna de C-S-H (produtos "inner"). Sua estrutura também é difícil de ser descrita. 
Os cristais de hidróxido de cálcio ${ }^{11}\left(\mathrm{Ca}(\mathrm{OH})_{2}\right)$ constituem $20 \%$ a $25 \%$ do volume de sólidos na pasta hidratada. A morfologia é afetada pelo espaço disponível, pela temperatura de hidratação e pela presença de impurezas. Há tendência em formar cristais grandes $(1 \mu \mathrm{m})$ sob a forma de prismas hexagonais distintos (com formas não definidas até pilhas de placas geometricamente bem definidas), conforme pode ser observado na Figura 13. O cristal de $\mathrm{CH}$ é o único composto da pasta que ocorre numa forma relativamente pura, com pequena quantidade de íons incorporados à sua estrutura. Nas primeiras idades o $\mathrm{CH}$ é facilmente encontrado em grandes vazios presentes na pasta de cimento. A presença de uma quantidade considerável de $\mathrm{Ca}(\mathrm{OH})_{2}$, que tem maior solubilidade que o $\mathrm{C}-\mathrm{S}-\mathrm{H}$, no cimento Portland hidratado tem efeito desfavorável sobre a resistência química à soluções ácidas. Seu potencial de contribuição para a resistência mecânica é menor, por causa da ação de forças de Van der Waals, conseqüência de uma área específica muito menor (MEHTA e MONTEIRO, 1994; NEVILLE, 1997).

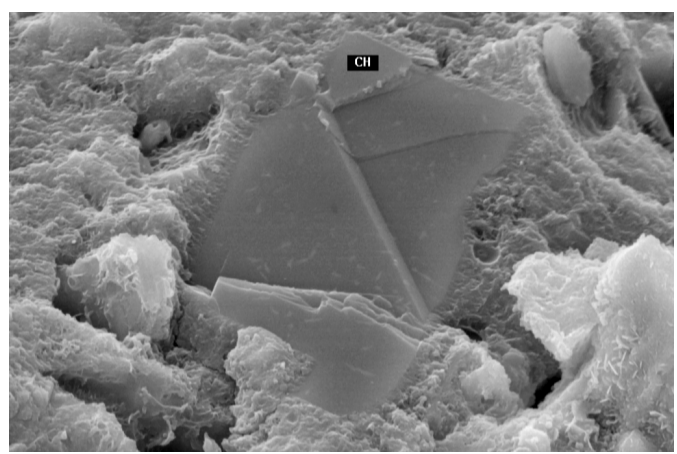

Figura 13: MEV 10.000x: Placas de hidróxido de cálcio $(\mathrm{CH})$. Fonte: Melo (2000).

Os sulfoaluminatos de cálcio hidratados ocupam de $15 \%$ a $20 \%$ do volume de sólidos na pasta endurecida, tendo um papel menor na relação estruturapropriedade. Nos primeiros estágios da hidratação, quando a concentração de íons

\footnotetext{
${ }^{11}$ Este produto também é denominado "portlandita" e sua abreviatura é "CH".
} 
sulfato na solução é relativamente alta, é favorecida a formação da etringita $\left(C_{6} A \overline{S_{3}} H_{32}\right)$, um trissulfoaluminato de cálcio hidratado (AFt), cujos cristais são tipicamente prismáticos aciculares (Figura 14). Esta fase eventualmente transforma-se em monossulfato hidratado $\left(C_{4} A \bar{S} H_{18}\right)$, cuja abreviatura é AFm, que cristaliza em placas hexagonais não empilhadas, mas agrupadas por ligações face-aresta, sendo sua presença desfavorável à resistência química à soluções sulfatadas (MEHTA e MONTEIRO, 1994). As fases AFt, AFm e C-S-H apresentam uma composição química muito variável e contêm uma quantidade substancial de outros íons incorporados.
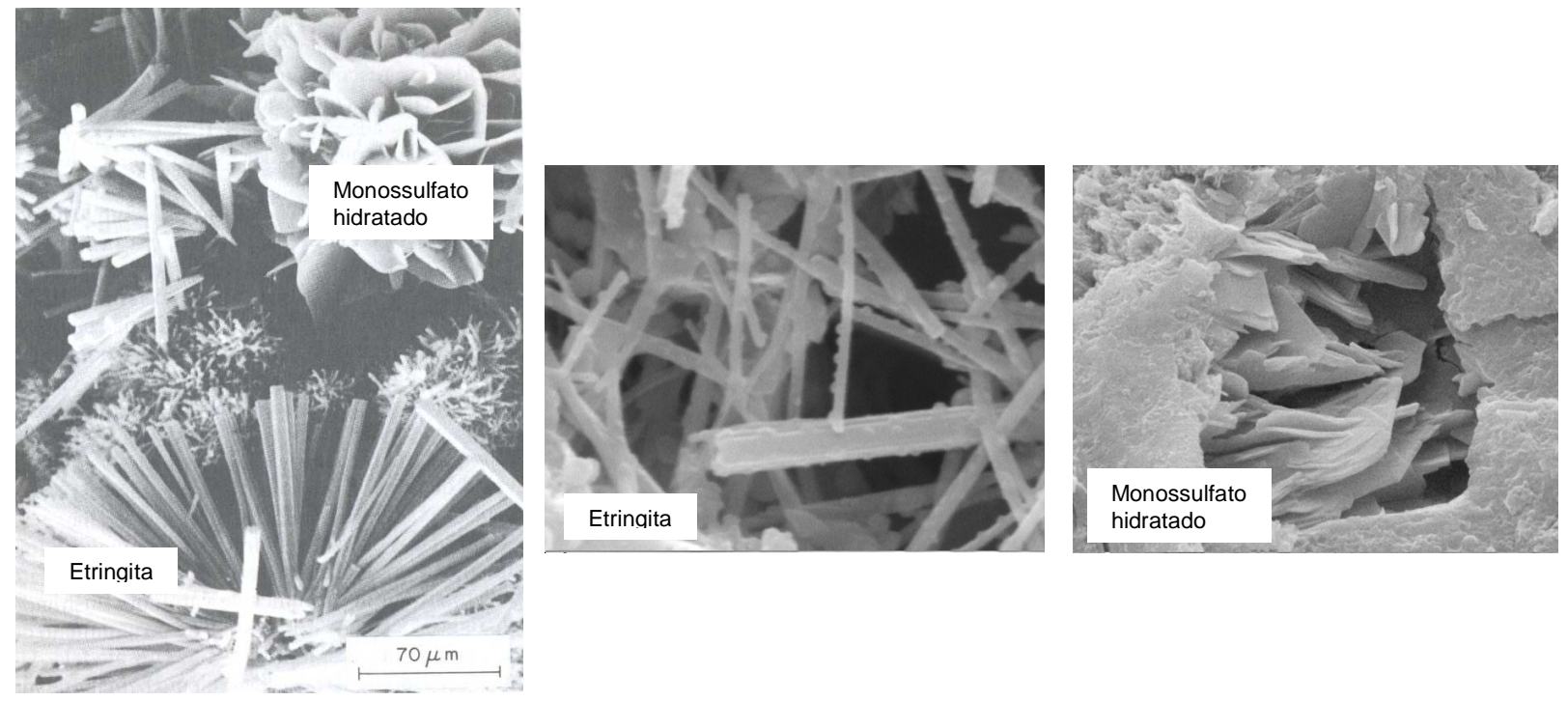

Figura 14: Etringita (AFt) e monossulfato hidratado (AFm). Fonte: Mehta e Monteiro (1994) e Melo (2000).

Algumas partículas de cimento não se hidratam (total ou parcialmente) permanecendo anidras. Isto se deve, principalmente, ao tamanho dos grãos e da quantidade de água disponível para se desenvolver a reação que, em casos de relações água-aglomerante baixíssimas, pode ser insuficiente. Os produtos da hidratação tendem a se cristalizar muito próximos das partículas do clínquer em 
hidratação, por causa do espaço limitado entre as partículas, isto dá a impressão da formação de um revestimento ao redor delas.

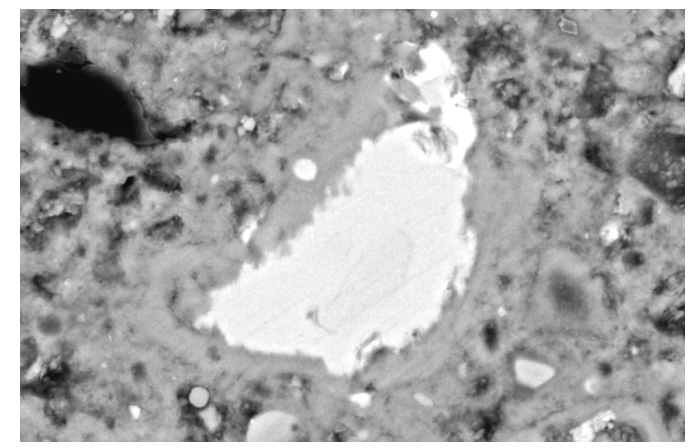

Figura 15: MEV 3.000x: Grão anidro em pasta de cimento Portland Fonte: Melo (2000).

Os concretos de elevado desempenho apresentam características microestruturais bastante diferentes dos concretos convencionais e dos concretos de elevada resistência, principalmente em relação à morfologia e propriedades das fases presentes, distribuição e morfologia do sistema poroso, matriz mais compacta, redução da quantidade de grandes cristais frágeis de hidróxido de cálcio e aumento das fases mais resistentes como o silicato de cálcio hidratado.

\subsubsection{Hidratação do Cimento Portland}

A hidratação do cimento Portland nada mais é que a reação dos seus compostos com água na presença de outras substâncias adicionadas intencionalmente ou inevitavelmente ao cimento. Ela acontece liberando calor para o ambiente, ou seja, é uma reação exotérmica, e transforma a mistura fluida de cimento e água em um sólido.

Os compostos do cimento Portland possuem hidratações diferentes, seja pela velocidade que ocorrem (Figura 16), seja pelas quantidades e produtos que delas resultam. 


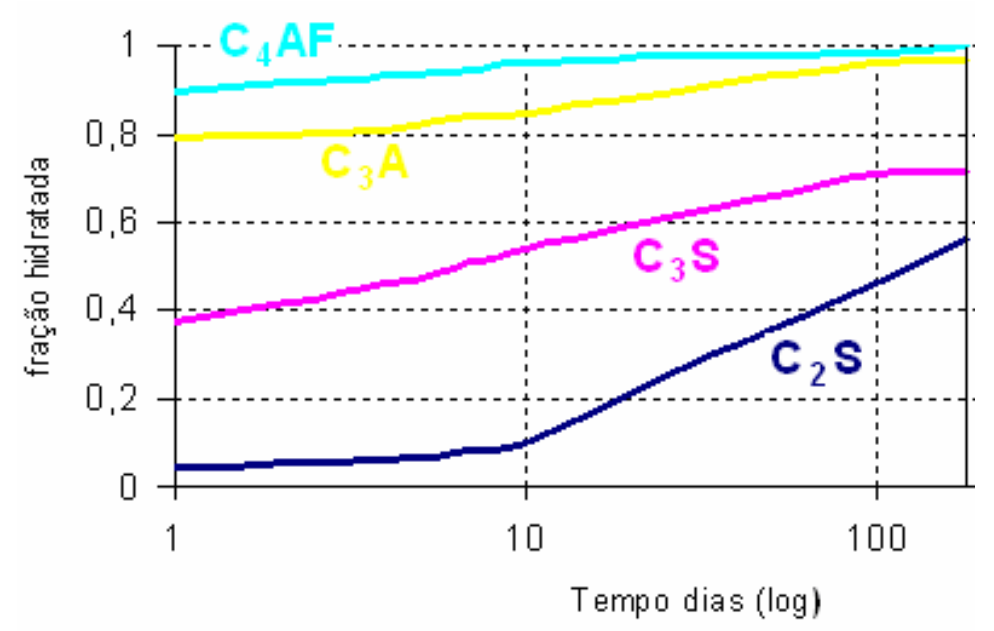

Figura 16: Evolução da hidratação dos compostos puros do cimento Portland. Fonte: Neville (1997).

O mecanismo de hidratação do cimento Portland acontece de dois modos diferentes: o mecanismo por dissolução-precipitação (dominante nos estágios iniciais) e o mecanismo topoquímico ou hidratação no estado sólido (dominante nos estágios posteriores).

O mecanismo de dissolução-precipitação consiste na dissolução de compostos anidros em seus constituintes iônicos, na formação de hidratos na solução e, devido à sua baixa solubilidade, numa eventual precipitação de hidratos provenientes da solução supersaturada. Em geral, sua duração corresponde a $30 \%$ da hidratação, entre 3 horas e 24 horas. Os produtos deste tipo de hidratação são chamados produtos de hidratação interna (inner). Um esquema simplificado deste mecanismo de hidratação está apresentado na Figura 17.

O mecanismo denominado topoquímico ou hidratação no estado sólido do cimento acontece quando as reações ocorrem diretamente na superfície dos componentes do cimento anidro sem entrarem em solução, fenômeno conhecido como deslocamento da interface. Pode ocorrer a hidratação da partícula residual quando a 
mobilidade iônica na solução torna-se restrita. Esta etapa independe da temperatura de cura. Os produtos deste tipo de hidratação são chamados produtos de hidratação externa (outer).

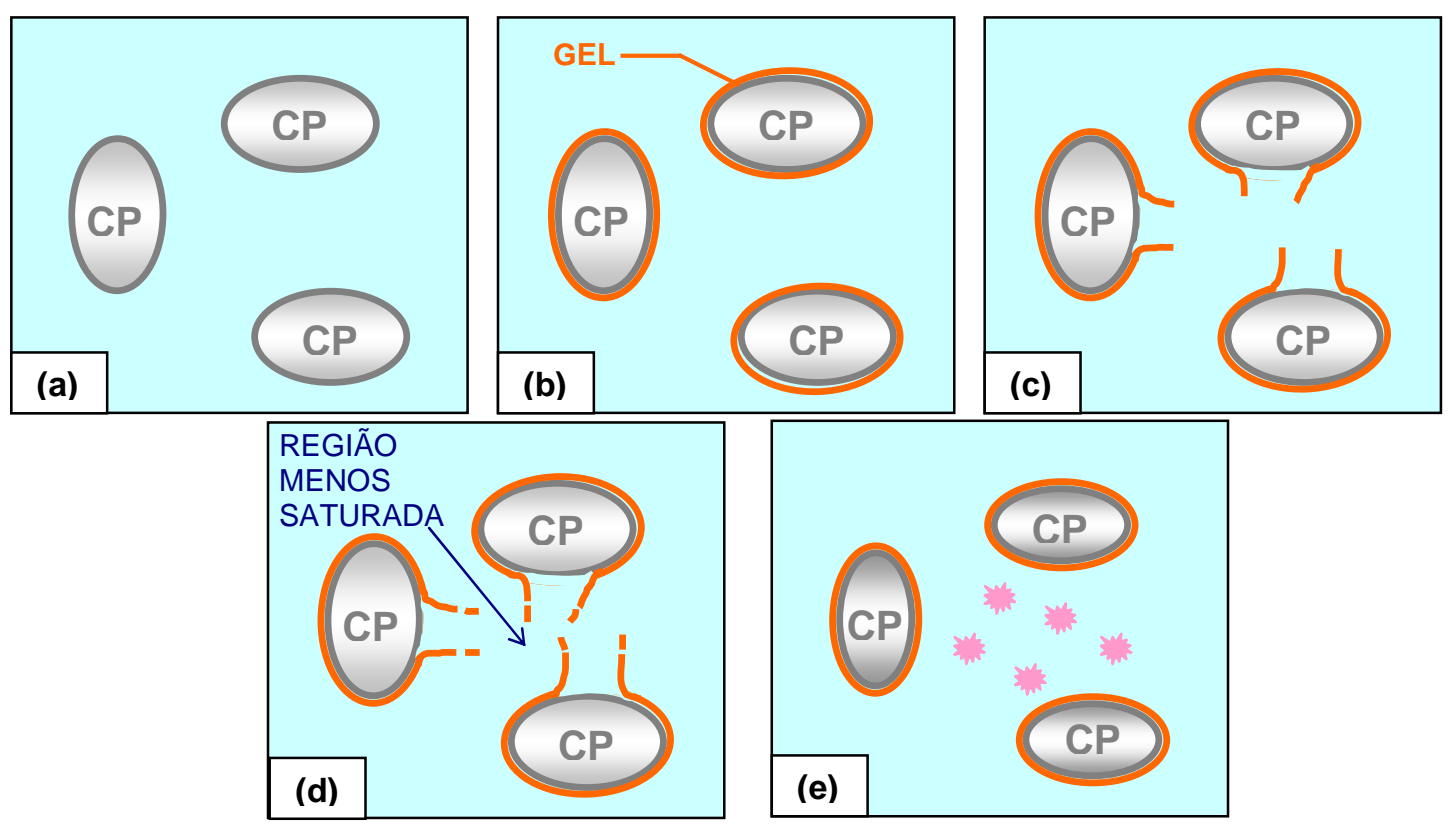

Figura 17. Esquema da hidratação do cimento Portland: mecanismo dissolução-precipitação.

(a) Grão de cimento entra em contato com a água;

(b) A água dissolve a superfície da partícula de cimento formando uma capa de gel de C-S-H;

(c) Por diferença de pressão (osmótica), rompe-se o gel;

(d) A água ataca novamente o gel. O gel vai para uma região menos saturada.

(e) O gel cristaliza no caminho; o processo continua...

A hidratação dos diferentes compostos do cimento Portland ocorre de forma simultânea, formando produtos de propriedades diferentes e com velocidade de reação diversa, o que torna necessário um estudo isolado da hidratação de cada fase.

Segundo Neville (1997) citando Le Chatelier, os silicatos de cálcio não se hidratam no estado sólido. O que provavelmente acontece é uma dissolução prévia dos silicatos anidros seguida da reação que forma silicatos hidratados menos solúveis que 
se precipitam da solução saturada (mecanismo dissolução-precipitação). Os silicatos de cálcio reagem formando, então $\mathrm{CH}$ e C-S-H. Já as fases aluminato e ferrita reagem com sulfato de cálcio formando AFt e AFm.

A hidratação de $\mathrm{C}_{3} \mathrm{~S}$ não se dá a uma velocidade constante. $\mathrm{A}$ liberação inicial rápida de $\mathrm{CH}$ que acontece para a solução deixa uma camada externa de $\mathrm{C}-\mathrm{S}-\mathrm{H}$ que dificulta a continuidade da hidratação. Eventualmente esta camada se rompe, possivelmente por um mecanismo osmótico ou pelo crescimento do $\mathrm{CH}$, e os produtos de hidratação dos grãos individuais entram em contato entre si, sendo estabelecido assim o fenômeno da pega.

Scrivener (1989) separa a hidratação do cimento em três fases principais:

(I) Entre 0 e 3 horas - fase que envolve grande liberação de calor; a taxa da evolução de temperatura decresce rapidamente para um mínimo depois de aproximadamente 3 horas. Este período inicial, durante o qual a mistura se mantém fluida e trabalhável, é comumente referendada como "período de indução". Este período é marcado por rápido crescimento da quantidade de $\mathrm{C}-\mathrm{S}-\mathrm{H}$ e $\mathrm{CH}$.

(II) Entre 3 e 24 horas - período em que cerca de $30 \%$ da hidratação ocorre, o que é refletido pelo pico máxima na taxa de evolução de temperatura. Depois deste pico, todos as partículas de cimento menores que $5 \mu \mathrm{m}$ estarão completamente hidratadas.

(III) Após 24 horas - período em que a taxa de evolução de temperatura diminui, entretanto a hidratação pode prosseguir 
indefinidamente. Há evidências que sugerem que neste período o mecanismo de hidratação é do tipo topoquímico.

De forma mais detalhada, nos primeiros 10 minutos de hidratação uma grande quantidade de calor é liberado. Este fenômeno coincide com a formação de

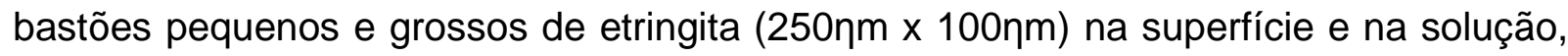
próximo à fase aluminato anidra. Em seguida, esta camada retrai-se por conseqüência da secagem e os cristais de AFt ficam próximos à superfície dos grãos do clínquer. A taxa de devolução de calor diminui rapidamente, iniciando o período de indução, durante o qual a concentração de íons $\mathrm{Ca}^{2+}$ na fase líquida alcança a supersaturação com relação ao $\mathrm{Ca}(\mathrm{OH})_{2}$. Inicia-se então a nucleação e o crescimento dos produtos $\mathrm{CH}$ e C-S-H. Nesse estágio de desenvolvimento da estrutura, há também formação de camadas finas de C-S-H ao redor dos grãos do clínquer. Assim, nas próximas 3 horas,

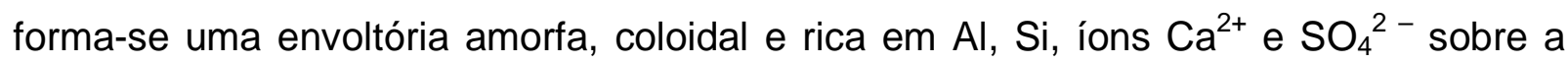
superfície dos grãos anidros (SCRIVENER, 1989; TAYLOR, 1992).

Grãos menores do que $5 \mu \mathrm{m}$ se hidratam completamente até o final da pega do cimento, proporcionando a formação de uma camada externa ("outer") de C-SH no espaço originalmente ocupado pela água. Na etapa da reação que ainda é controlada quimicamente por dissolução-precipitação, há a formação de uma camada interna de C-S-H ("inner"), quando a partícula se dissolve, deixando um espaço vazio (carapaça vazia) conhecido como "grão de Hadley". Essas carapaças começam a formar-se por volta de 12 horas após o início da hidratação, sendo mais perceptível após 18 horas. Elas não se constituem numa barreira impermeável para o fluxo de íons dissolvidos, pois à medida que a hidratação prossegue, tanto o espaço interno quanto o externo são, progressivamente, preenchidos com compostos hidratados. Os grãos 
tornam-se completamente envolvidos após 4 horas e a envoltória sobre a superfície dos grãos anidros cresce para fora dos mesmos. Após 12 horas, a espessura dessa

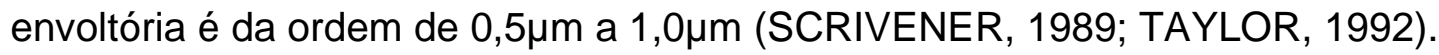

No período intermediário (3 a 24 horas), há um aumento subseqüente na concentração de íons $\mathrm{Ca}^{2+}$ da fase líquida, que induz à nova aceleração da dissolução da alita, há liberação de grandes quantidades de calor e há redução da porosidade global da pasta. Esse fenômeno é resultado da precipitação contínua e rápida de C-S-H e de outros produtos hidratados. Observa-se também que os cristais em crescimento englobam os grãos de cimento menores. $\mathrm{O} C a(O H)_{2}$, na forma de plaquetas finas, e o C-S-H começam a formar contatos entre os grãos e desenvolve-se um esqueleto contínuo de produto hidratado (SCRIVENER, 1989; TAYLOR, 1992). As envoltórias dos grãos adjacentes começam a se juntar, o que coincide com a máxima liberação de calor de hidratação. Ao final deste período, crescem novamente os cristais de AFt (aciculares), que chegam a dimensões de 2,0 $\mu \mathrm{m}$ até $10,0 \mu \mathrm{m}$ de comprimento. Este processo desempenha papel importante na evolução das propriedades mecânicas (SCRIVENER, 1989; TAYLOR, 1992). No período final, o C-S-H começa a depositar-se também no interior das envoltórias, que neste momento devem ter espessura aproximada de $8 \mu \mathrm{m}$ (SCRIVENER, 1989).

Por volta de 1 a 3 dias, uma grande quantidade de $C_{3} A$ já reagiu com os sulfatos, produzindo etringita. No caso de existirem quantidades menores de sulfatos disponíveis, a etringita dissolve-se e reage com o $\mathrm{Al}(\mathrm{OH})^{4-}$, resultando na formação de monossulfoaluminato de cálcio $(\mathrm{AFm})$. Essa reação deve ocorrer depois do pico principal de desenvolvimento de calor, atribuído à hidratação da alita. Nos cimentos 
com baixo teor de $\mathrm{C}_{3} \mathrm{~A}$, mas com excesso de sulfato de cálcio, a fase $A F m$ não se forma (SCRIVENER, 1989; TAYLOR, 1992).

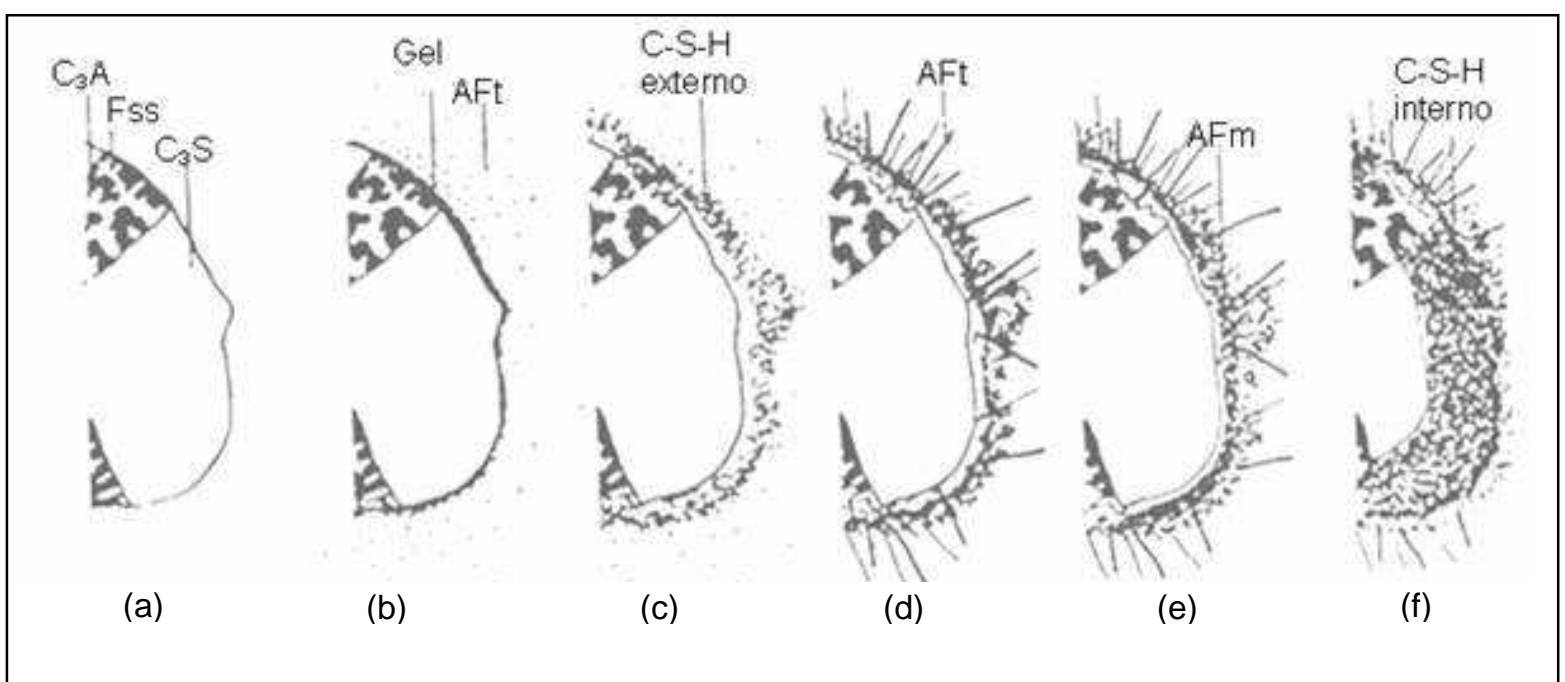

Figura 18. Desenvolvimento da microestrutura durante a hidratação do cimento Portland. Fonte: Scrivener (1989).

(a) Grão de cimento anidro;

(b) 10min: reação de $C_{3} A$ com sulfato em solução; formação de gel rico em alumina com a presença de AFt em forma de pequenos bastonetes;

(c) 10h: formação de produtos de hidratação externa (C-S-H) pela reação de $\mathrm{C}_{3} \mathrm{~S}$ e $\mathrm{AFt}$, formando um envoltório no grão anidro situado a $1 \mu \mathrm{m}$ deste (grão de Hadley);

(d) 18h: hidratação secundária da AFt, formando longos bastonetes. Início da hidratação interna;

(e) 1 a 3 dias: formação de AFm internamente ao envoltório pela reação de $\mathrm{C}_{3} \mathrm{~S}$ com AFt;

(f) 14 dias: preenchimento do espaço de $1 \mu \mathrm{m}$ entre o envoltório e o grão anidro pela formação de C-S-H oriundo da hidratação interna. O C-S-H proveniente da hidratação externa torna-se mais fibroso.

O próximo estágio, após a etapa de aceleração das reações de hidratação, é caracterizado pelo baixo desenvolvimento de calor e por uma diminuição da velocidade global da reação, e pode ser relacionado com a etapa em que há o preenchimento dos espaços entre as envoltórias e entre a envoltória e o núcleo. A partir desse momento, a reação é cada vez mais lenta e continua por mecanismo topoquímico, ou seja, ela é controlada pela difusão dos íons e pela deposição de 
produtos hidratados nos poros. Os produtos hidratados, como os $\mathrm{CH}$, envolvem parte do C-S-H formado anteriormente (SCRIVENER, 1989; TAYLOR, 1992).

Aproximadamente após 7 dias, os grãos de cimento, entre $5 \mu \mathrm{m}$ e $15 \mu \mathrm{m}$, reagem completamente, tornando a camada externa de C-S-H mais densa. Os grãos anidros do clínquer tornam-se cada vez menores e muitos deles desaparecem do sistema. Essa descrição do desenvolvimento da microestrutura durante a hidratação do cimento Portland até 14 dias pode ser visualizada na Figura 18. Segundo Liborio (2004), pela ausência da formação das fases indicadas na Figura 18 causada por uma cura ineficiente, haverá também uma perda de resistência mecânica.

Scrivener (1989) relaciona o tamanho dos grãos de cimento com o tipo de C-S-H formado. Para a autora, grãos menores que $5 \mu \mathrm{m}$ se hidratam completamente até o pico máximo da evolução de calor e dão origem a C-S-H externo (outer) nos vazios preenchidos originalmente com água. Partículas entre 5 e $15 \mu \mathrm{m}$ terão reagido após aproximadamente 7 dias e produzem C-S-H externo e interno. Somente o núcleo das partículas maiores que $15 \mu \mathrm{m}$ serão eventualmente hidratadas e formarão C-S-H do tipo interno por um mecanismo lento de solidificação. Esta é uma das razões dos cimentos finos modernos serem piores em relação à durabilidade, eles não formam este C-S-H adicional interno em idades mais avançadas.

Grãos de cimento Portland podem permanecer não hidratados, formando grãos anidros. Estas partículas não são prejudiciais e podem ser consideradas como um agregado muito fino com excelente aderência aos produtos de hidratação (AÏTCIN e NEVILLE; 2003).

Alguns aspectos da reação de hidratação do cimento são de grande interesse para os usuários, por exemplo, o conhecimento da quantidade de calor 
liberado, da velocidade de reação, que é importante na determinação do tempo de pega e de endurecimento.

As equações abaixo pretendem dar uma orientação sobre a reação de hidratação do $\mathrm{C}_{3} \mathrm{~S}$ e $\mathrm{C}_{2} \mathrm{~S}$ (NEVILLE, 1997).

Para o $\mathrm{C}_{3} \mathrm{~S}$ :

$$
\text { 2. } \mathrm{C}_{3} \mathrm{~S}+6 . \mathrm{H} \rightarrow \mathrm{C}_{3} \mathrm{~S}_{2} \mathrm{H}_{3}+3 . \mathrm{Ca}(\mathrm{OH})_{2}
$$

Para o $\mathrm{C}_{2} \mathrm{~S}$ :

$$
\text { 2. } \mathrm{C}_{2} \mathrm{~S}+4 . \mathrm{H} \rightarrow \mathrm{C}_{3} \mathrm{~S}_{2} \mathrm{H}_{3}+\mathrm{Ca}(\mathrm{OH})_{2}
$$

A partir de uma análise com base nas massas, os dois silicatos necessitam de quantidades semelhantes de água, mas $0_{3} \mathrm{C}_{3} \mathrm{~S}$ produz mais que o dobro de hidróxido de cálcio que $\mathrm{O}_{2} \mathrm{C}$. Mas é importante considerar que diferentes componentes de um clínquer resultam em produtos de hidratação também diferentes e, conseqüentemente, há uma variação na quantidade de água envolvida na reação de hidratação.

O mecanismo de hidratação na zona de transição depende da relação água-aglomerante da mistura. Se esta relação for baixa, a Z.T. pode estar livre ou conter poucos vazios preenchidos com água não permitindo que a hidratação se dê por mecanismo dissolução-precipitação. Como conseqüência, a hidratação se procede somente por difusão (AÏTCIN e NEVILLE; 2003).

A temperatura afeta a cinética da hidratação. O seu aumento, acelera as reações iniciais, embora o grau de hidratação e o desenvolvimento de resistência mecânica, em geral, sejam reduzidos nas idades mais avançadas. A temperatura age provocando mudanças na solubilidade dos componentes do cimento. A sensibilidade à 
temperatura é maior quando a reação é controlada por processo químico, mais precisamente entre o início e fim de pega (MELO; 2000).

\subsubsection{Outros aspectos relacionados ao Cimento Portland}

A escolha do tipo de cimento deve ser feita em função de todas as variáveis envolvidas, ou seja, não apenas em função da disponibilidade de mercado, mas também das propriedades que o concreto a ser produzido poderá ter. A seleção é extremamente importante uma vez que o material exerce influência tanto na resistência como na aderência pasta-agregado o que refletirá na durabilidade final do concreto. Além das propriedades mecânicas, o cimento também afeta substancialmente os produtos com ele confeccionados pela sua finura, composição química e sinergia com os outros constituintes químicos, como os aditivos e adições.

Em termos de finura, quanto maior for a superfície específica em contato com a água, mais rapidamente ocorrerá a hidratação do cimento, aumentando-se a resistência à compressão, principalmente nas primeiras idades. Por outro lado, quanto mais fino o cimento, maior a dosagem de superplastificante necessária para se alcançar a mesma trabalhabilidade, já que a eficiência do aditivo é influenciada diretamente pela finura. São recomendáveis cimentos com constituintes com ação pozolânica, como as sílicas ativas (como a de ferro-silício e a cinza da casca de arroz) e a escória de alto forno.

Os cimentos modernos são mais finos e ricos em $\mathrm{C}_{3} S$ que os de antigamente. Apesar de proporcionarem resistências à compressão superiores nas primeiras idades, a utilização desses cimentos deve ser vista com cautela pois, de 
acordo com Aïtcin (2000), misturas elaboradas com os cimentos atuais podem ter sua durabilidade afetada, especialmente sob condições marítimas, de gelo-degelo e se submetidas à sais.

O consumo de cimento por metro cúbico é outro fator dominante tanto do ponto de vista técnico quanto econômico. O consumo de cimento utilizado na fabricação do $C A D$, em geral, varia entre $400 \mathrm{~kg} / \mathrm{m}^{3}$ a $550 \mathrm{~kg} / \mathrm{m}^{3}$, enquanto que no convencional esse valor é de aproximadamente $300 \mathrm{~kg} / \mathrm{m}^{3}$. A utilização de quantidades maiores de cimento por metro cúbico deve ser vista com cautela, já que, segundo Neville (1997), teores acima de $530 \mathrm{~kg} / \mathrm{m}^{3}$ podem levar a uma queda de resistência mecânica em virtude de perda de aderência entre a pasta e o agregado resultante da fissuração por tensões de retração. Para solucionar este problema, pode-se substituir parte do cimento por outros materiais cimentícios, como a sílica ativa e a cinza de casca de arroz, ou aumentar a eficiência do cimento com o auxílio dos aditivos superplastificantes.

Como é possível notar, são vários fatores em conjunto que determinam as propriedades de um cimento. Entretanto é possível haver necessidades que os cimentos comerciais podem não atender ou apresentem desempenho insatisfatório. Nestes casos seriam necessárias mudanças nas frações dos componentes ou mesmo inclusão de adições que modifiquem a composição e comportamento dos compósitos em que este aglomerante pudesse ser inserido. Estas adições interferem, principalmente, no desenvolvimento da resistência, calor de hidratação, durabilidade. Este cimento modificado, como mencionado anteriormente, poderia ser denominado de "novo cimento ou aglomerante" (LIBORIO; 2004). 


\subsection{AGREGADOS}

Freqüentemente, os agregados são considerados como um material de enchimento inerte do concreto e argamassa. No entanto, com o crescente conhecimento do papel fundamental desempenhado por eles em muitas propriedades destes compósitos, este ponto de vista vem sendo seriamente questionado (MEHTA e MONTEIRO; 1994).

As propriedades do agregado graúdo afetam as propriedades de aderência agregado-pasta e na quantidade de água requerida. A aderência entre o agregado e a pasta de cimento tem grande importância na resistência, especialmente à flexão. A aderência é advinda da forma (angulosa) e textura superficial (áspera) do agregado e, em parte, ao intertravamento do agregado e da pasta de cimento hidratada. No entanto, segundo Mehta e Monteiro (1994), a forma e a textura das partículas dos agregados influenciam mais nas propriedades do concreto fresco do que do endurecido; comparadas às partículas lisas e arredondadas, as partículas de textura áspera, as angulosas e as alongadas requerem mais pasta de cimento para produzir misturas trabalháveis e, portanto, aumentam o custo do concreto e a possibilidade de ocorrer retração.

Para os agregados graúdos, recomenda-se que o módulo de elasticidade seja maior ou igual ao da pasta de cimento. $\mathrm{O}$ agregado a ser utilizado deve estar limpo, pouco poroso e livre de fissuras e imperfeições na superfície.

Outro fator que deve ser observado é o teor máximo de álcali reagente com o cimento. Depois de alguns anos, alguns agregados podem sofrer reações químicas. Uma das mais preocupantes é a reação álcali-agregado (RAA), na qual 
componentes do agregado reagem com os álcalis do cimento formando um gel, que pode absorver água e se decompor, causando fissuração no concreto.

Agregados graúdos de menores dimensões, segundo o ACl 211.4R-93, têm demonstrado melhor desempenho na resistência do concreto. Segundo Aïtcin (2000), apesar de com o aumento no tamanho máximo do agregado proporcionar uma pequena redução na exigência de água para determinada trabalhabilidade, isto não é suficiente para compensar a perda de resistência que ocorre com a conseqüente ampliação da zona de transição e o fato dela tornar-se mais heterogênea. Além disso, partículas menores do agregado graúdo são, geralmente, mais resistentes que as partículas grandes.

Como já mencionado no capítulo sobre microestrutura de CAD, para o agregado graúdo, a forma eqüidimensional das partículas é mais adequada, pois aquelas que se afastam desse formato têm maior área superficial e se acomodam de modo anisotrópico.

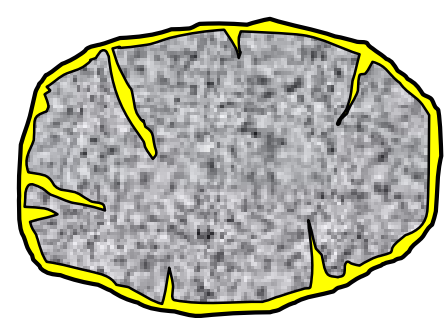

Figura 19: Esquema de agregado frágil, poroso tratado com dopagem superficial. Adaptado de Liborio (2004).

Como nem sempre bons agregados graúdos estão disponíveis para a utilização, e seus defeitos afetarão o concreto, é preciso tratá-los para que se tornem adequados ao uso. Liborio (2004) sugere fazer uma dopagem dos agregados. Este processo consiste em lavar o agregado com uma solução de baixa relação águacimento ou com uma solução com sílica ativa (Figura 19). Além de promover uma 
melhoria nos agregados, a dopagem, no caso de utilização de materiais muito finos como a cinza da casca de arroz ou sílica de ferro-silício, evita a formação de grumos, isto é, amontoados de partículas.

Quanto aos agregados miúdos, a forma de suas partículas e a textura de suas superfícies podem ter um grande efeito no consumo de água e na resistência à compressão do concreto. São preferíveis as partículas arredondadas e lisas porque exigem menos água de amassamento.

O agregado adequado para concretos de elevado desempenho deve ser resistente, sem alterações mineralógicas cristalinas finas, pois agregados com minerais parcialmente modificados, com fissuras intra e intergranular, além da presença de plano de laminação e clivagem, enfraquecem o agregado, afetando a resistência final do concreto.

\subsection{ADITIVO SUPERPLASTIFICANTE}

Os superplastificantes são aditivos químicos que consistem de tensoativos aniônicos de cadeia longa, massa molecular elevada com um grande número de grupos polares na cadeia de hidrocarbonetos.

As partículas de cimento Portland têm uma forte tendência para flocularem quando misturadas com água, resultado de interações de vários tipos (forças de van der Waals entre partículas, forças eletrostáticas entre regiões com cargas opostas, e forte ligação envolvendo moléculas de água ou hidratos) (MELO, A. B.; 2000). Este fenômeno tem efeito negativo para a trabalhabilidade e impede a hidratação nas primeiras idades. A floculação também ocorre nas partículas muito finas adicionadas ao 
cimento, como as da cinza da casca de arroz, pela mesma razão que no cimento Portland. No entanto, é possível deflocular as partículas com a utilização de superplastificantes na mistura.

Quando absorvido pelas partículas de cimento, o aditivo confere uma forte carga negativa, diminuindo consideravelmente a tensão superficial da água circundante e tornando a partícula de cimento hidrófila (que atrai a água). Com a neutralização das cargas elétricas na superfície das partículas de cimento, há liberação de água que ficaria aprisionada nos flocos. Como conseqüência, menos água será consumida para determinada trabalhabilidade (Figura 20). No caso dos superplastificantes de polinaftalenos, polimelamídios ou lignosulfonados isto se dá por processo eletrostático. Já os superplastificantes policarboxilados agem por efeito estério também (Figura 21).

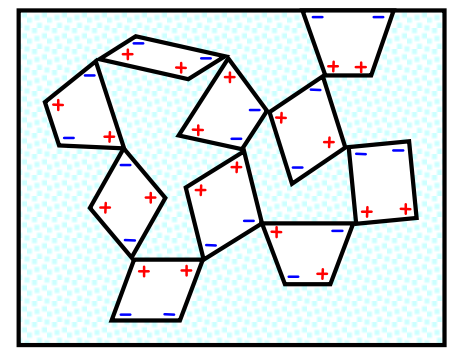

(a)

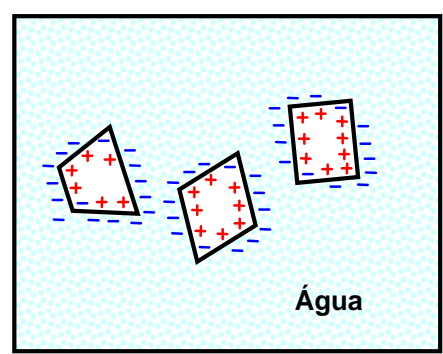

(b)

Figura 20: Partículas de cimento sem e com superplastificante.

(a) sem superplastificante; (b) com superplastificante, partículas dispersas.
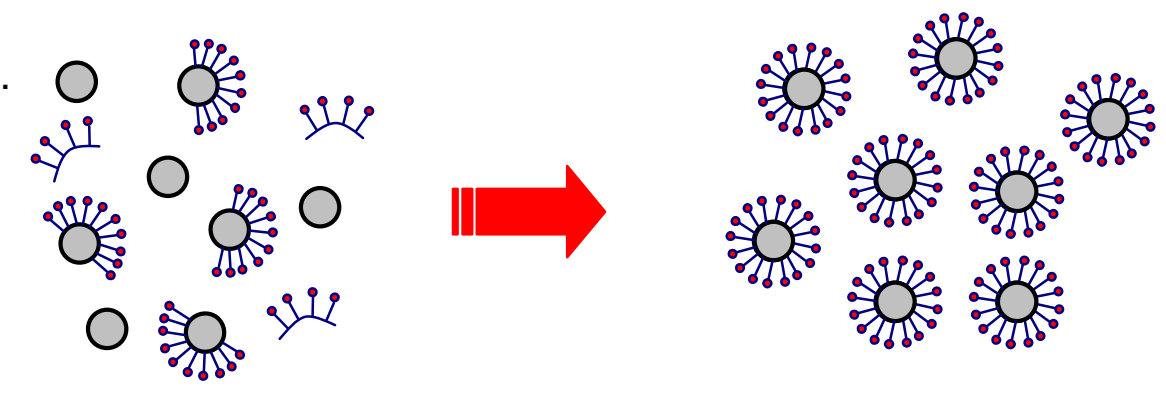

Figura 21: Ação do superplastificante. 
Com o início do processo de hidratação do cimento esse efeito de dispersão é minimizado, fazendo com que o concreto perca trabalhabilidade, necessitando de adição de água para manter a mesma trabalhabilidade (Figura 22).
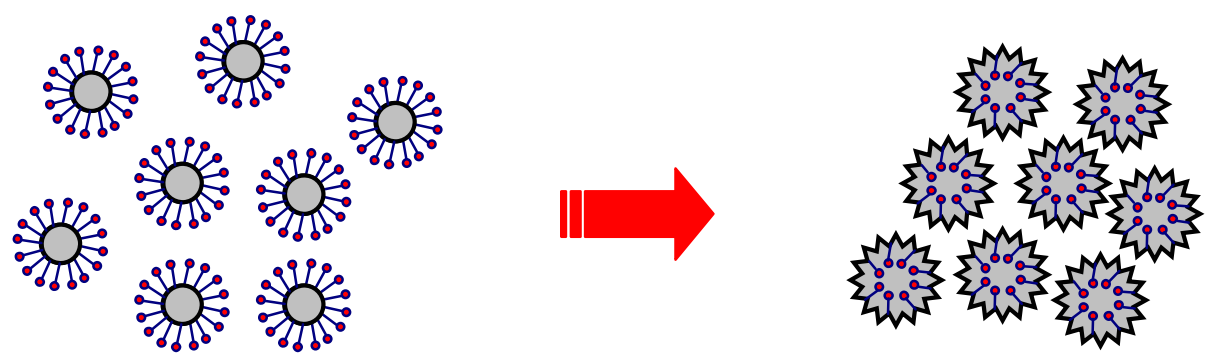

Figura 22: Perda da trabalhabilidade do superplastificante.

Os superplastificantes de última geração à base de policarboxilatos, conseguem resultados superiores aos superplastificantes à base de melamina e à base naftalenosulfonato. Eles atuam de forma mais completa nas partículas de cimento. Somado à ação eletrostática conseguida pelo carregamento nas partículas de cimento de cargas de mesmo sinal, o policarboxilato possui longas cadeias laterais ("side chains"), responsáveis pelo chamado efeito estério (Figura 23).

Figura 23: Molécula de policarboxilato. Fonte: < http://www.degussa-cc.com.br>

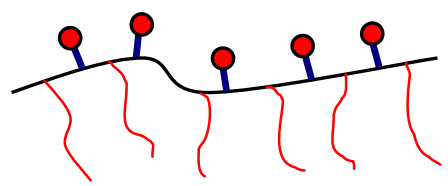

Essas longas cadeias laterais aumentam o espaço físico em um sistema de partículas de cimento, resultando em uma redução de água muito superior aos superplastificantes normais (acima de $40 \%$ ), Figura 24.
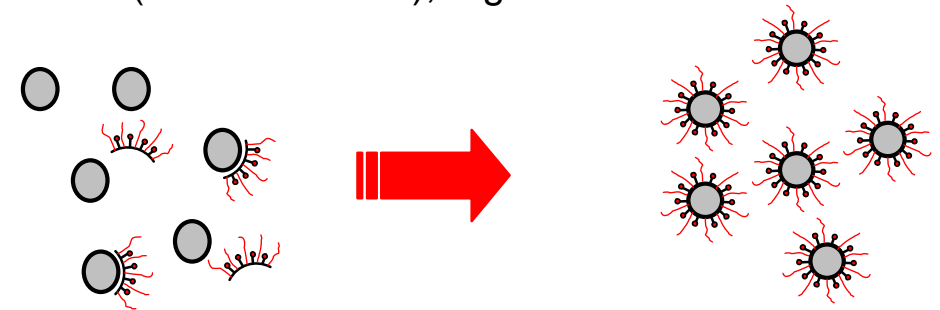

Figura 24: Ação do policarboxilato sobre as partículas de cimento. 
Outra grande vantagem que se deve às longas cadeias laterais do policarboxilato é a manutenção da trabalhabilidade por longos períodos. Com o início do processo de hidratação do cimento, perde-se o efeito da repulsão eletrostática do aditivo mas, pela presença das mesmas, consegue-se minimizar esse efeito.
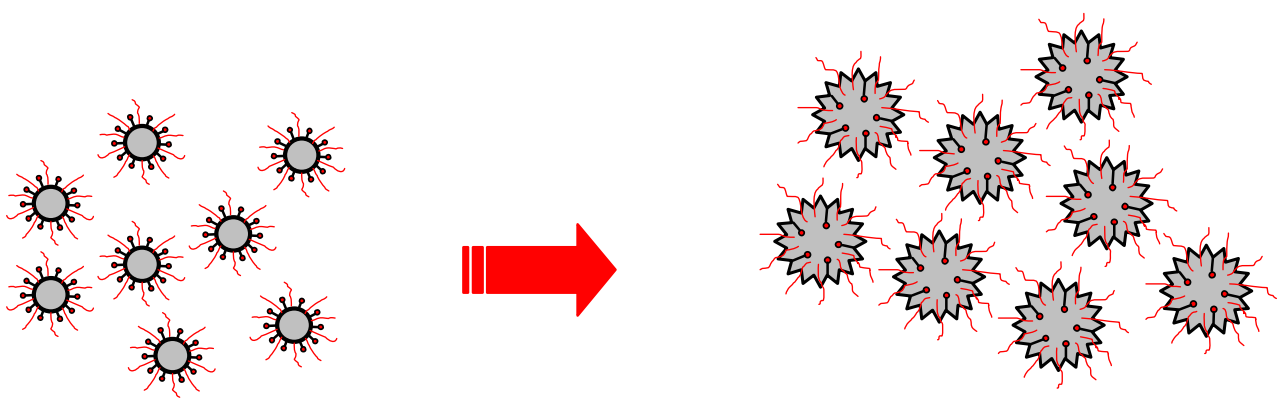

Figura 25: Manutenção da trabalhabilidade pelo efeito estério. Adaptado de < http://www.degussa-cc.com.br> (acesso em 15/07/2005).

Os superplastificantes não trazem vantagens só em relação à trabalhabilidade, mas também à resistência. Com sua ação defloculante, esses aditivos químicos permitem que a hidratação do cimento seja mais efetiva e eficiente, melhorando a zona de transição e a matriz da pasta (LIBORIO; 2005). O ACI 363 R:92 para dosagens de concretos de altas resistências faz uma distinção em suas planilhas quanto ao uso ou não de superplastificantes, mostrando que, entre concretos similares, os com superplastificante apresentam resistências mais elevadas .

\subsection{ADIÇÕES MINERAIS}

As adições minerais são materiais muito interessantes em concretos e argamassas não somente pela melhoria na resistência e durabilidade que 
proporcionam, mas também pela questão ecológica. A maioria delas são subprodutos industriais sem valor econômico que acabam se transformando em agentes poluentes de aqüíferos e do solo. Elas se tornam viáveis na composição de compósitos à base de cimento quando possuem a propriedade de reagir com o hidróxido de cálcio $\left(\mathrm{Ca}(\mathrm{OH})_{2}\right)$, e formar um outro produto, o silicato de cálcio hidratado (C-S-H), o qual é o maior responsável pela resistência das pastas de cimento. Esta capacidade é característica das pozolanas e é chamado efeito pozolânico. Este efeito pode ser evidenciado na Figura 26 que traz uma microscopia de uma amostra fraturada de concreto com adição de cinza da casca de arroz com idade de 28 dias e magnificação de 12000x, na qual são percebidos feixes fibrosos de C-S-H em formação em meio à placas sobrepostas de hidróxido de cálcio, e nas proximidades bastões aciculares de Etringita (AFt). A constatação desta reação é de extrema importância, pois confirma dados de atividade pozolânica da cinza da casca de arroz residual.

Figura 26: MEV 28 dias, amostra fraturada, 12000x. Fonte: Fagury e Liborio (2004).

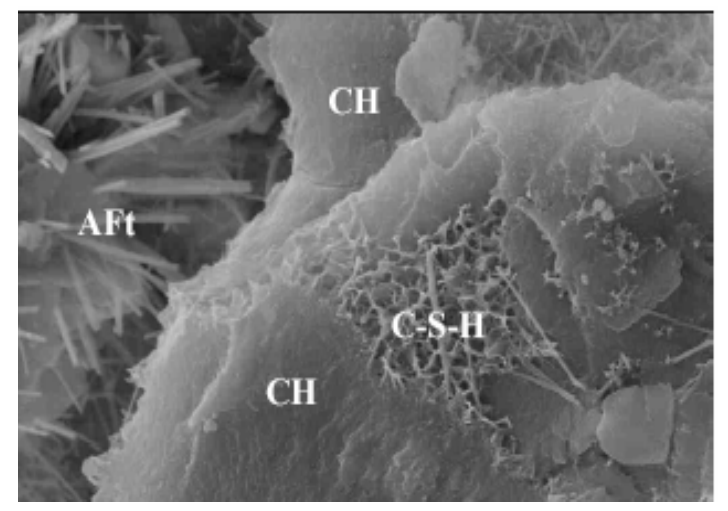

Uma das adições mais utilizada para CAD é a sílica ativa, que é um material com altas porcentagens de sílica $\left(\mathrm{SiO}_{2}\right)$ na sua composição. O seu desempenho se deve as suas propriedades físico-químicas, que Ihe conferem uma grande reatividade com o hidróxido de cálcio. A sílica ativa normalmente é subproduto industrial. A sílica de ferro-silício (SFS), que é resultante do processo de fabricação do 
silício metálico ou das ligas de ferro-silício, tem diâmetro médio entre 50 a 100 vezes menor que o do cimento e baixa massa unitária. Das termoelétricas da indústria de beneficiamento de arroz, obtêm-se as cinzas da casca de arroz (CCA) que podem, ainda, ser tratadas para formar a sílica branca da casca de arroz. A cinza da casca de arroz é o objeto deste trabalho.

Goldman e Bentur (1993) demonstraram que o efeito da adição de sílica ativa, no caso a de ferro-silício, pode ser tão importante quanto o efeito da redução de água para o aumento da resistência à compressão de concretos. Ele chamou de efeito inerte o que é causado pela sílica. A Figura 27 mostra os seus resultados.

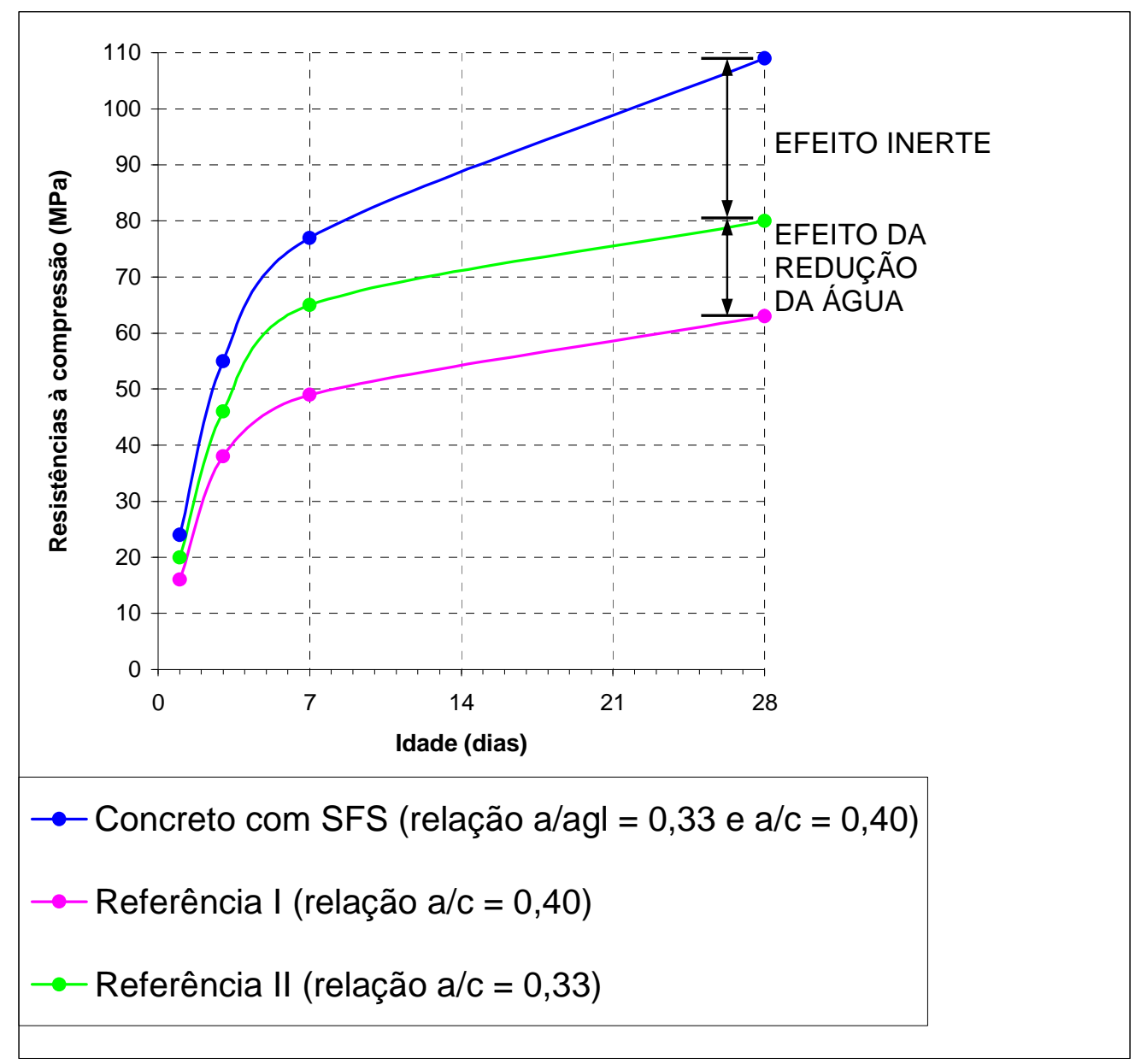

Figura 27: Efeito da sílica de ferro-silício em comparação com o efeito da redução de água. Fonte: Goldman e Bentur (1993). 


\subsubsection{Reação Pozolânica e Efeito Fíler}

As pozolanas beneficiam o concreto de duas maneiras: quimicamente pelo seu efeito pozolânico e fisicamente, pelo efeito fíler.

A reação pozolânica, como mencionado anteriormente, é a reação da adição com o hidróxido de cálcio formado pela hidratação ou cimento formando C-S-H. Esta reação é mais lenta que a reação de hidratação do $\mathrm{C}_{3} \mathrm{~S}$ do cimento Portland. Isto implica em uma taxa de liberação de calor e de desenvolvimento da resistência mais lentos também. Além disso, o C-S-H formado pela reação pozolânica apresenta características melhores.

Reação rápida do $\mathrm{C}_{3} \mathrm{~S}$ do cimento Portland:

$$
\mathrm{C}_{3} \mathrm{~S}+\mathrm{A} G U A \rightarrow \mathrm{C}-\mathrm{S}-\mathrm{H}+\mathrm{CH}
$$

Reação lenta da pozolana:

$$
\text { POZOLANA + CH + ÁGUA } \rightarrow \text { C-S-H }
$$

Mehta (1983) afirma que "reação pozolânica" não é somente aquela entre hidróxido de cálcio e sílica, mas inclui todas as reações cimentícias no sistema CaO $\mathrm{SiO}_{2}-\mathrm{Al}_{2} \mathrm{O}_{3}-\mathrm{Fe}_{2} \mathrm{O}_{3}-\mathrm{SO}_{3}-\mathrm{H}_{2} \mathrm{O}$. A diferença maior entre a "reação pozolânica" e as "reações cimentícias" na hidratação do cimento Portland é principalmente em relação às taxas de reação, que costumam ser mais lentas, e não aos produtos de hidratação. Entretanto, a reação pozolânica, como outras reações químicas, pode ser acelerada pela temperatura e por aceleradores químicos. 
Bentur e Cohen (1987) em sua pesquisa sobre o efeito da sílica ativa (de ferro-silício) na microestrutura da zona de transição de argamassas verificaram a efetiva melhoria desta região pela reação pozolânica, conforme pode ser notado na Figura 28.

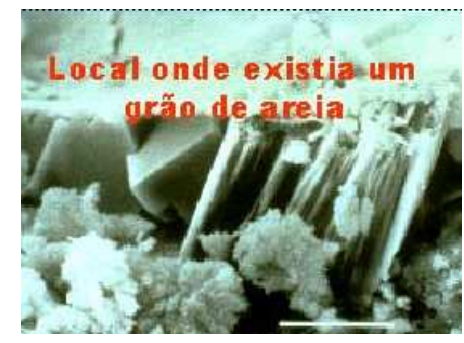

(a)

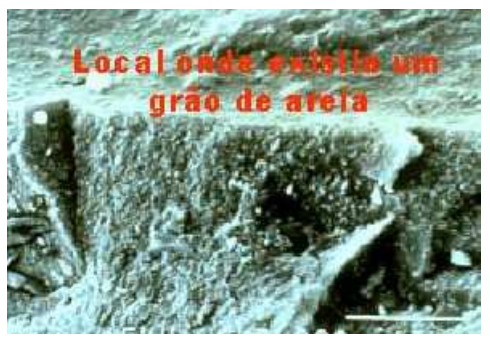

(b)

Figura 28: Microestrutura da zona de transição entre a pasta e um grão de agregado. (a) sem sílica ativa; (b) com sílica ativa. Fonte: Bentur e Cohen (1987).

A função química das sílicas ativas no processo de hidratação é governada pela disponibilidade de hidróxido de cálcio. Depois de um certo tempo, a sílica deixa de reagir quimicamente de maneira significativa como um aglomerante. $\mathrm{O}$ restante da sílica atuará como um fíler inerte, contribuindo fisicamente. Esta contribuição acontece porque os finos preenchem os vazios entre as partículas maiores (efeito de empacotamento), e como conseqüência, reduz o tamanho dos vazios pela segmentação dos poros maiores na pasta e a porosidade, e aumenta a durabilidade do concreto. Este é o fenômeno que ocorre entre as partículas da sílica e as do cimento, geralmente com dimensões bem maiores (Figura 29). Além disso, a presença de fílers aumenta a quantidade de locais de nucleação para a precipitação dos produtos de hidratação da pasta de cimento, acelerando as reações e formando cristais menores de hidróxido de cálcio (SENSALE, 2000). 


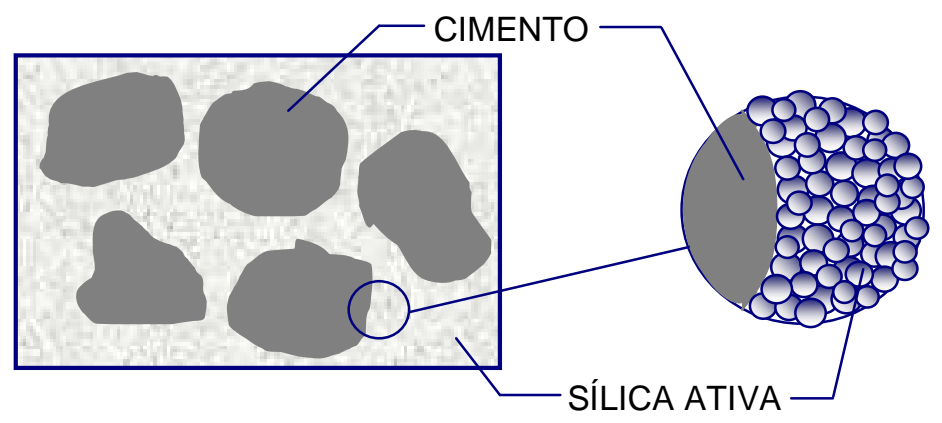

Figura 29: Efeito fíler das sílicas ativas.

O efeito fíler combinado com o efeito pozolânico contribuem, segundo Goldman e Bentur (1993), na eliminação da exsudação. No mesmo trabalho, os autores estudaram pastas executadas com adição de $18 \%$ de um carbono inerte (sem atividade pozolânica), com adição de $18 \%$ de sílica de ferro-silício (SFS) e pastas de referência sem nenhuma adição. A diferença entre a resistência do concreto com carbono e o de referência, segundo os autores, pode ser usada para estimar o efeito fíler. O efeito pozolânico pode ser estimado a partir da diferença entre as resistências do concreto com sílica e o com carbono. Ambos os efeitos estão representados na Figura 30. A figura também mostra que o efeito fíler é mais significativo que o pozolânico, apesar deste último ser mais importante por causa da durabilidade.

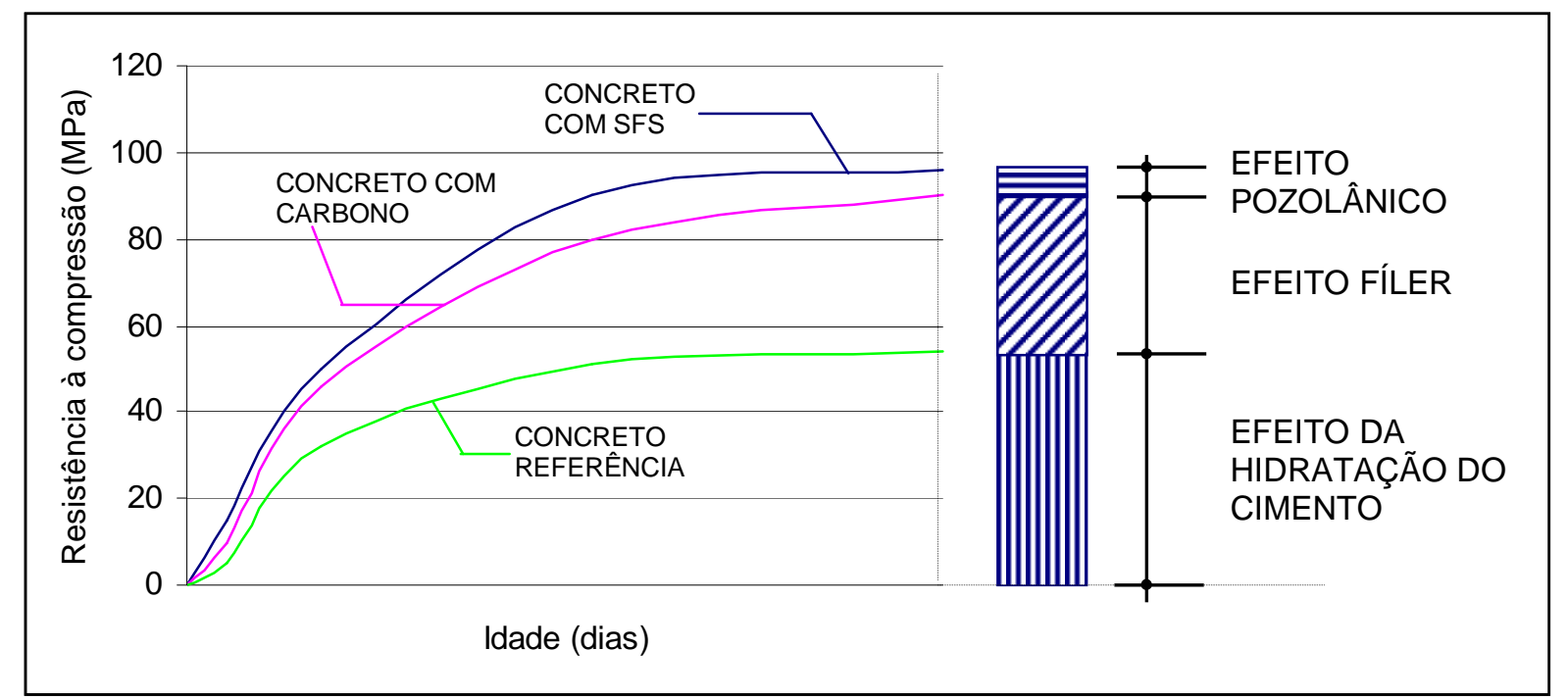

Figura 30: Contribuição dos efeitos pozolânico e fíler na resistência à compressão de concretos. Fonte: Goldman e Bentur (1993) 
Isaia (2000) faz um estudo similar ao de Goldman e Bentur, mas chega a resultados diferentes. O autor utilizou fíler calcário em vez de carbono como material inerte, e cinza da casca de arroz como material pozolânico. Isaia conclui com sua pesquisa que o efeito fíler foi sempre inferior ao pozolânico, mesmo variando a porcentagem de adição (12,5\%, 25\% e 50\%), o tempo de hidratação (28 e 91 dias) e o $\mathrm{f}_{\mathrm{ck}}$ (utilizou concreto convencional de 35MPa e de alta resistência de 65MPa).

No CAD com adições minerais, pelo elevado teor de finos, há enormes benefícios advindos do efeito de refinamento e desconexão dos poros. O efeito de refinamento dos poros é explicado pela natural condição de hidratação do cimento Portland que gera, entre outros produtos, o hidróxido de cálcio, que vai reagir com a sílica gerando C-S-H adicional. Outra explicação é o efeito do tamponamento dos poros. Este refinamento provoca modificações na microestrutura da zona de transição tornando-a mais densa e forte que um concreto sem finos. Um concreto convencional pode atingir resistências significativas pela redução do consumo de água, como diz a Lei de Abrams, mesmo assim estas resistências são mais baixas que a de uma pasta similar. Concretos com presença de sílicas apresentam comportamento contrário, segundo Goldman e Bentur (1993). Segundo eles, a sílica melhoraria a aderência pasta-agregado, o traria um conseqüente aumento da contribuição do agregado para a resistência.

A presença da sílica ativa também influi nas propriedades dos produtos de hidratação. O gel de C-S-H produzido pela hidratação do cimento tem alta relação $\mathrm{Ca} / \mathrm{Si}$ e é quimicamente estável apenas em solução supersaturada de $\mathrm{CH}$. Por isso, a baixa quantidade de $\mathrm{CH}$ numa pasta com sílica ativa pode causar a decomposição do gel de C-S-H. Na medida em que a sílica ativa reage com $\mathrm{CH}$ formando um novo C-S-H com 
baixa relação $\mathrm{Ca} / \mathrm{Si}$, a concentração de $\mathrm{CH}$ é gradualmente reduzida e aquele $\mathrm{C}-\mathrm{S}-\mathrm{H}$, ainda presente com alta taxa $\mathrm{Ca} / \mathrm{Si}$, torna-se instável e se decompõe (LI et al., 1996).

A incorporação de finos em concretos, geralmente melhora a coesão das partículas e, conseqüentemente, diminui consideravelmente a segregação e exsudação do concreto fresco. Apesar disto, a presença de finos no concreto dificulta a subida da água até a superfície, existe um risco de fissuração, principalmente quando a taxa de evaporação é elevada. Para evitar este problema, deve-se proteger a superfície do concreto fresco da perda de água mediante a utilização de um método eficaz de cura. (SENSALE, 2000).

\subsubsection{Influência das Adições Minerais em Propriedades Mecânicas}

A utilização de adições minerais em compósitos à base de cimento, em geral, é bastante vantajosa do ponto de vista das propriedades mecânicas, como compressão, tração e módulo de elasticidade.

As adições minerais atuam tornando a matriz da pasta mais densa e, portanto, menos porosa, pelo aumento na quantidade de produtos resultantes das reações de hidratação e pozolânica. A zona de transição sofre modificações importantes com a presença das sílicas ativas como a diminuição da quantidade de cristais orientados de hidróxido de cálcio, dos espaços vazios e aumento da adesividade pasta-agregado, contribuindo para a resistência mecânica e nas relações tensão-deformação no concreto. A melhoria pode ser tanta que a zona de transição pode, até mesmo, ser eliminada.

A resistência à compressão é, em geral, a propriedade mais importante dos compósitos à base de cimento, entre outros motivos, porque é requisito 
estabelecido pela NBR6118:2003 para garantir a vida útil de determinada construção. Como ela está diretamente ligada à estrutura interna do material, fornece uma importante estimativa sobre a durabilidade. A velocidade de ganho de resistência nas primeiras idades é afetada pela presença de sílicas ativas, pois a proximidades entre as partículas dos componentes que irão reagir (sílica e cimento) aumenta, ou seja, aumentam os pontos de nucleação. Isto ocorre, entre outras razões, pelo melhor empacotamento provocado pelo efeito fíler.

O comportamento mecânico do agregado na estrutura de concreto, dependendo de sua forma e disposição no interior da argamassa e com a presença de exsudação interna, poderá ser similar a de uma viga simplesmente apoiada e, com determinado carregamento, poderá ser rompido facilmente por flexão ou cisalhamento. Com a introdução da sílica ativa ocorre a diminuição desse fenômeno tanto pelo efeito fíler quanto pelo pozolânico, comportando-se o agregado confinado como uma viga contínua com apoios muito próximos um do outro, aumentando assim a resistência do sistema como um todo. A Figura 31 ilustra a atuação da sílica ativa na interface pastaagregado do concreto.

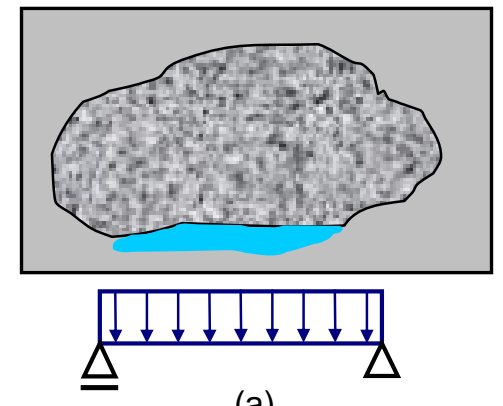

(a)

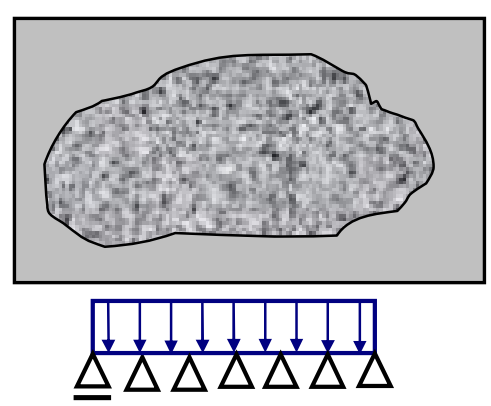

(b)

Figura 31: Efeito da sílica ativa na zona de interface pasta-agregado.

$$
\text { Fonte: Liborio (2004). }
$$


Goldman e Bentur (1993) concluíram que em misturas contendo finos, a resistência à compressão do concreto é sempre superior à da pasta equivalente, contrariando o que acontece com concretos convencionais. Isto ocorre, segundo os autores, pelo melhoramento da zona de transição e, conseqüentemente, da adesividade entre pasta e agregado, fazendo com que este contribua de forma mais efetiva na resistência. Isto torna a escolha do agregado fundamental, pois suas propriedades afetarão de forma significativa na resistência do concreto.

O módulo de elasticidade vem diretamente da relação tensão-deformação do material. O limite de elasticidade representa a deformação máxima permitida antes do material adquirir deformação permanente. Em materiais heterogêneos, multifásicos como o concreto, a fração volumétrica, a massa específica e o módulo de elasticidade dos principais constituintes e as características da zona de transição determinam o comportamento elástico do compósito. Como a massa específica é inversamente proporcional à porosidade, os fatores que afetam a porosidade dos agregados, da matriz da pasta de cimento e da zona de transição também afetam o módulo de elasticidade. O módulo de elasticidade de concretos com adições de sílicas, assim como às resistências mecânicas, também aumentam, mas de forma mais amena por causa da forte influência do agregado no módulo de deformação e da proporção, em volume, do agregado no concreto e, nos concretos com adições, é a matriz que sofre as maiores transformações.

Assim como a resistência à compressão de compósitos com adições de sílicas ativas, a resistência à tração também apresenta uma taxa de crescimento alta nas primeiras idades. Dal Molin (1995) observou que uma adição de 10\% em relação à 
massa de cimento de sílica de ferro-silício provocou um aumento de $22,5 \%$ nos resultados obtidos por ensaios de resistência à tração por compressão diametral.

Conforme já comentado, a sílica ativa causa uma redução na porosidade da matriz e na zona de transição. Isto leva a um aumento da resistência à tração. Este aumento é relativamente pequeno até que a resistência intrínseca dos produtos de hidratação da zona de transição seja mais significativa, isto é, a resistência à tração do concreto com uma zona de transição com menor porosidade continuará a ser fraca enquanto uma grande quantidade de cristais orientados de $\mathrm{CH}$ estiverem presentes.

\subsubsection{Outros aspectos relacionados às adições minerais}

As dosagens de sílica ativa geralmente empregadas no CAD se encontram na faixa entre $5 \%$ e $15 \%$ sobre a massa de cimento. Teores menores que 5\% não resultam em aumento de resistência, segundo Neville (1997), pois esta quantidade de adição é insuficiente para permitir o fortalecimento da interface agregado-pasta. Teores maiores que 15\% resultam em menores ganhos de resistência e aumentos consideráveis no custo final do concreto, quando a adição empregada é a de ferro-silício, que tem alto custo em relação ao cimento.

Melo (2000) comenta que pastas com baixa relação água-cimento e com sílica de ferro-silício contêm muito menos água não evaporável. Esta diferença estaria relacionada a maior energia superficial da sílica ativa. Como a área superficial das partículas de sílica é muito alta, a quantidade de água adsorvida é maior. Como resultado, menos água está disponível para reagir com as partículas de cimento nas 
primeiras idades, agravando a situação no caso de misturas com relações águacimento muito baixas, pois já se tem uma quantidade de água reduzida.

Os autores Goldman e Bentur (1993) estudaram pastas e concretos executados com de um carbono inerte (18\%), sílica de ferro-silício (18\%) e pastas de referência. Foram utilizados carbonos com três finuras diferentes em pastas, e estes desenvolveram resistências à compressão similares (Figura 32). O mesmo já não aconteceu nas misturas de concretos, que tinham matrizes equivalentes às pastas (mesma relação água-cimento e mesma proporção de adição), que mostraram um crescimento da resistência com o decréscimo do tamanho da partícula, provavelmente resultado da melhoria da zona de transição. Os autores estimam que a variação entre as resistências das misturas com relações água-cimento diferentes $(0,4$ e 0,46$)$ seria resultado do efeito da redução da água.

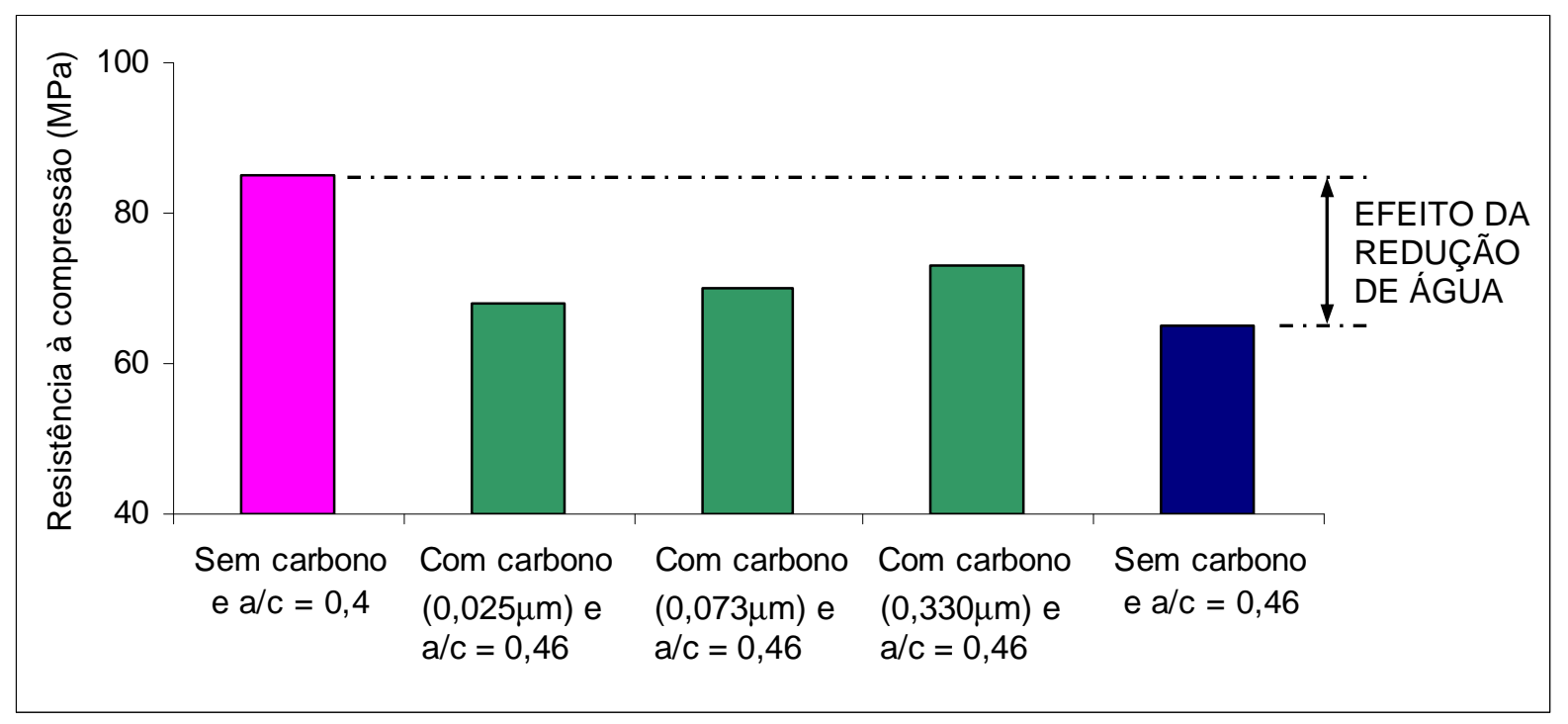

Figura 32: Efeito da redução de água e da finura do fíler na resistência à compressão de pastas. Fonte: Goldman e Bentur (1993). 


\section{CINZA DA CASCA DE ARROZ}

A casca de arroz é uma capa lenhosa do grão, dura, com alto teor de sílica, composta de aproximadamente $50 \%$ de celulose, $30 \%$ de lignina e $20 \%$ de sílica de base anidra (MEHTA, 1992). Quando queimada, a lignina e a celulose podem ser removidas, resultando uma estrutura celular e porosa, como mostra a Figura 33.

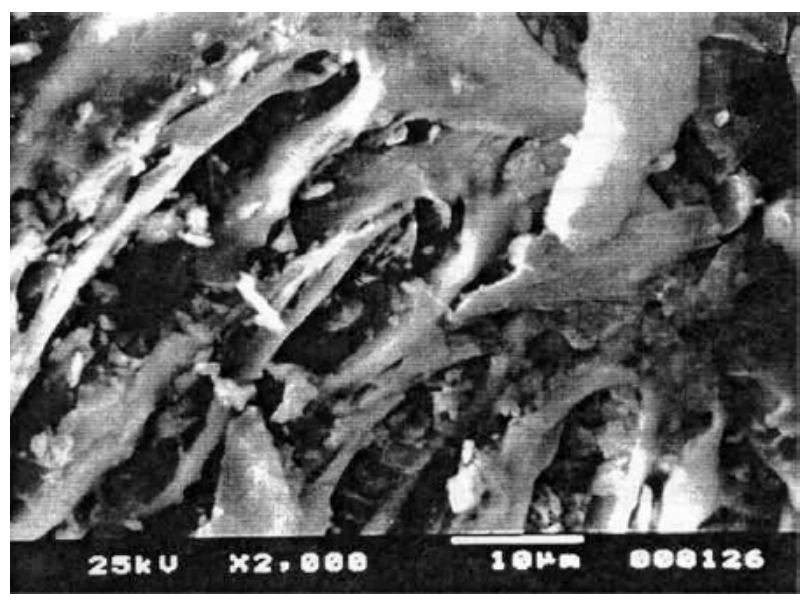

Figura 33: MEV da cinza de casca de arroz queimada a $560^{\circ} \mathrm{C}$. Fonte: Silveira e Ruaro (1995).

Da queima da casca de arroz para geração de energia elétrica nas usinas de beneficiamento de arroz, obtém-se um resíduo negro constituído de sílica com até $15 \%$ de carbono que poderá ser nociva à saúde (silicose), causar danos ambientais, etc. Esta cinza, em geral, apresenta alta pozolanicidade. O formato das partículas da cinza da casca de arroz é mais angular que o da sílica de ferro-silício que é esférica.

O RILEM Technical Reports de 1988 inclui a CCA produzida por combustão controlada nas adições minerais usadas no cimento ou no concreto como altamente pozolânica, juntamente com a sílica ativa de ferro-silício. Sua composição é essencialmente constituída de sílica pura na forma não cristalina e as suas partículas 
são geralmente menores que $45 \mu \mathrm{m}$ e área específica por absorção de nitrogênio de $60 \mathrm{~m}^{2} / \mathrm{g}$

\subsection{HISTÓRICO}

Pesquisas sobre produção de cinza de casca de arroz (CCA) que poderiam ser usadas em concretos não são recentes. A utilização de arroz em concreto já era objeto de estudo desde 1924 com Beagle na Alemanha. Mais tarde, nos anos 40 e 50, diversos autores se dedicaram ao estudo de blocos feitos de uma mistura de cimento Portland, cinza e casca de arroz. Em 1973, Mehta teve uma importante colaboração com uma patente na Bélgica, na qual publicou o primeiro de uma série de textos de sua autoria sobre o assunto. Neste trabalho, Mehta investigou sobre o efeito da queima na atividade pozolânica. Baseado neste texto, em 1976, Pitt desenvolveu estudo sobre um leito fluidizado para o controle da combustão. Percebeu que, dependendo do tempo que o material permanece queimando e quando a temperatura interior é controlada, as cinzas poderiam ser produzidas com pozolanicidade mais elevada. Metha e Pitt publicam então em 1976, um artigo relatando o uso industrial da patente, que consiste num processo de queima da casca inteira em leito fluidizado, capaz de produzir uma cinza altamente reativa e de cor negra (Figura 34).

Em 1974, uma planta piloto que produz cinza foi construída na área de Sacramento, na Califórnia, e na seqüência, em 1975, uma planta comercial maior foi instalada em Stuttgart, Arkansas. A cinza obtida era empregada para produzir cimento e outros produtos industriais. Os cimentos produzidos pelas unidades experimentais de Sacramento e Stuttgart foram empregados na construção de pavimentos de concreto utilizados em ambientes muito agressivos (SENSALE; 2000). Já naquela época 
algumas indústrias americanas, como a "Riceland Foods", começaram a utilizar a casca de arroz para geração de calor baseada no processo de Mehta e Pitt.

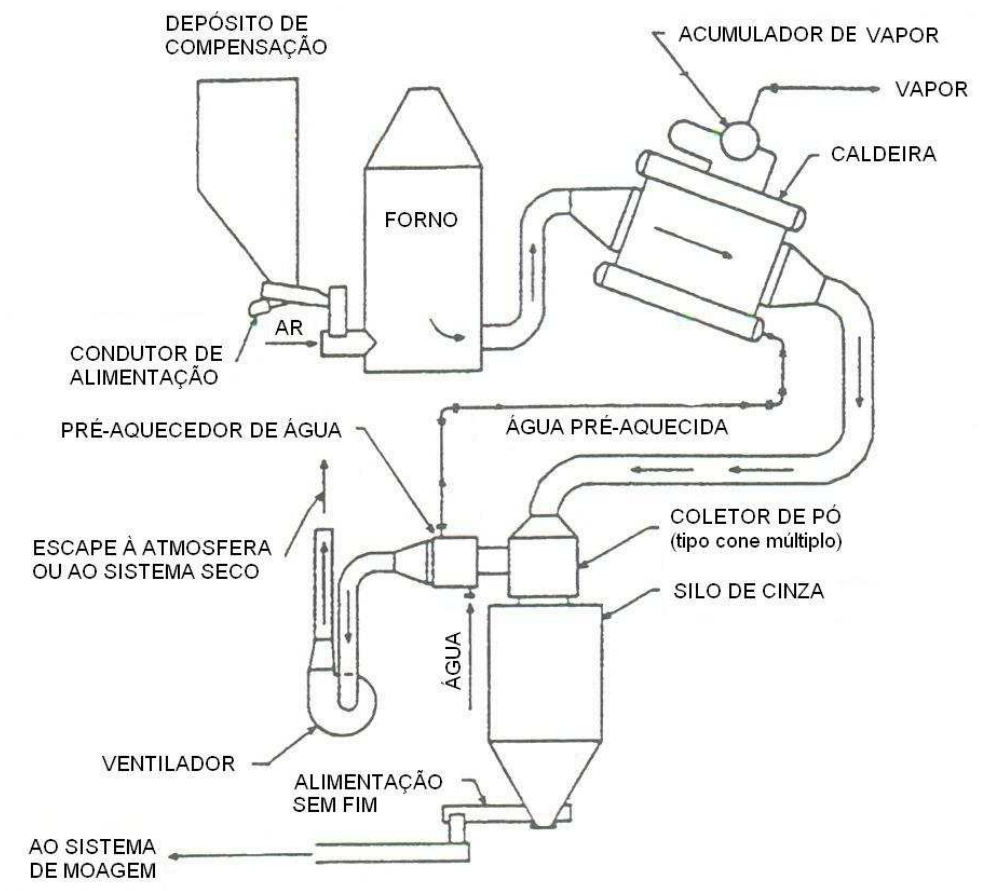

Figura 34: Esquema do fluxo da planta para produzir CCA e vapor. Fonte: Mehta e Pitt (1976) ${ }^{12}$ apud Sensale (2000).

Sensale (2000) fez um resumo dos principais trabalhos sobre cinza da casca de arroz ao longo do tempo, o qual foi aproveitado e complementado neste trabalho.

Em 1974 -1976, pesquisas no Indian Institute of Technology em Kanpur na Índia, direcionaram-se à produção de cimento na qual empregava-se cinza produzida pela combustão da casca de arroz no processo de parboilização do arroz, similar a empregada nesta pesquisa. Prakash (1979) reporta o emprego deste tipo de cimento para trabalhos de alvenaria e fundações, mas aponta problemas causados por

\footnotetext{
${ }^{12}$ MEHTA, P.K., PITT, N. (1976). A new process of rice husk utilization. In: International Conference on the Utilization of Rice By-products, Valencia, Spain, 1974. proceedings... Valencia: IATA, 1977, p.45-58.
} 
deficiências no controle de qualidade do processo e pelas propriedades variáveis dos materiais empregados na fabricação do cimento.

Mehta e Polivka (1976) fazem o relato do emprego de CCA como adição pozolânica altamente ativa para reduzir a expansão devida á reação álcali-agragado. Mehta e Pirtz (1978) propõem a substituição de cimento Portland por cinza de casca de arroz em construções de concreto massa, com baixos consumos de cimento e proporções de cinza de casca de arroz elevadas (>30\%). Cook e seus associados (1976 e 1981) relataram os resultados dos estudos do Asian Institute of Technology no uso de CCA como adição mineral em concreto de cimento Portland, os quais pesquisaram fluência e retração dos concretos.

Em 1979, aconteceu o primeiro workshop sobre o assunto no Paquistão e, no mesmo ano, na Malásia, Alor Selar demonstrou a CCA sendo aplicada em argamassas. Em 1984, a "United Nations Industrial Development Organization" (UNIDO) publicou uma coletânea de trabalhos sobre o desenvolvimento de cimentos com base na cinza de casca de arroz, incluindo processo de produção.

No Cement Research Insitute (Nova Delhi, Índia), Chopra (1979) confirmou, por análise de difração de raios-X, que a CCA obtida por combustão por duas horas a $600^{\circ} \mathrm{C}$, continha sílica na forma amorfa, permanecendo essencialmente amorfa para temperaturas de incineração de até $700^{\circ} \mathrm{C}$. Os autores confirmam que com o aumento do tempo e temperatura de incineração, a sílica tende a virar cripto-cristalina (formas cristalinas), deste modo reduzindo a atividade pozolânica da cinza. Também apresentam estudos de moagem nos quais mostram que a cinza não cristalina foi muito mais fácil de pulverizar do que a cinza cristalina. Paralelamente com as pesquisas 
sobre a CCA altamente pozolânica na Índia, pesquisou-se a produção de tijolos com cal-CCA residual.

Para produzir uma cinza altamente pozolânica, Kapur (1981) projetou um tubo queimador de casca de arroz com temperaturas de incineração entre 600 e $700^{\circ} \mathrm{C}$ produzindo cinza não cristalina com área superficial de aproximadamente $60 \mathrm{~m}^{2} / \mathrm{g}$, detectando-se cristobalita (forma cristalina) quando empregava-se temperatura de $800^{\circ} \mathrm{C}$.

No Japão, Yamamoto e Lakho (1982) apresentaram os resultados das pesquisas da Universidade de Tsukuba na produção e emprego de CCA ativa como material cimentício suplementar.

Baseados na dissertação de Hana Yousif da University of Technology (Bagdad, Iraque), Al-Khalaf e Yousif (1984) descreveram o efeito dos parâmetros da queima e moagem da cinza de casca de arroz no índice de atividade pozolânica e nas propriedades de argamassas, mostrando que com a substituição de até $40 \%$ de cimento por CCA, não são observadas diferenças significativas na resistência à compressão em relação às misturas de controle.

Em 1986, James e Rao relataram os resultados de um estudo abrangente do Institute of Science (Bangalore, Índia) do efeito das condições de queima da casca de arroz sobre as características físicas e atividade química da cinza produzida. Morfologia, tamanho de partículas, área específica, distribuição de poros e fases cristalográficas fizeram parte de sua pesquisa.

Também em 1986, Salas et al apresentaram os estudos realizados no Instituto Eduardo Torroja (Espanha) sobre as propriedades físico-químicas da cinza de casca de arroz obtida pela combustão controlada num forno piloto de 400 litros de 
capacidade e o seu emprego como adição em argamassas, nas quais concluíram que as resistências obtidas com CCA e cimento são superiores às obtidas com CCA e cal. Também estudaram a influência do tipo de cura e da quantidade de água em concretos com cinza da casca de arroz, mostrando que o tipo de cura é um fator decisivo na resistência à compressão quando as dosagens têm 33 ou $50 \%$ de substituição de cimento por CCA e relação água-aglomerante igual a 0,77 , encontrando resistências superiores às do concreto de controle.

Em 1989, Hwang e Wu apresentaram as pesquisas sobre as características físico-químicas da cinza produzida sob diferentes temperaturas, hidratação característica e microestrutura de pastas de cimento com diferentes relações água-cimento e frações de CCA no National Insitute of Technology (Taiwan). Algumas das conclusões a que chegaram foram que as condições da combustão afetam a qualidade da cinza; o calor de hidratação tem variação inversa à relação águaaglomerante e a CCA acelera o desenvolvimento da resistência, pois modifica o mecanismo da hidratação.

Boateng e Skeete, em 1990, apresentaram as pesquisas feitas no Institute of Applied Science and Technology (Turkeyen, Guiana) sobre a atividade pozolânica da cinza obtida da casca de arroz queimada à temperatura de $800-900^{\circ} \mathrm{C}$ em um pequeno incinerador (capacidade aproximada de $50-60 \mathrm{~kg}$ de arroz). A cinza obtida foi amorfa e altamente reativa, e as argamassas produzidas aos 3 e 38 dias apresentaram resistências à compressão 8 a 31\% maiores de que as de controle respectivamente.

Na década de 90, Mehta (1992) apresenta uma revisão das características físico-químicas da casca de arroz e dos efeitos das condições de combustão nas propriedades pozolânicas da cinza obtida deste processo, bem como os resultados de 
diversas investigações do emprego de CCA como material cimentício suplementar e uma revisão de estudos recentes nas propriedades de cimentos e concretos que contêm CCA. Em 1993, Malhotra faz uma revisão dos efeitos produzidos por diferentes pozolanas empregadas no concreto, incluindo a CCA.

Em 1994, Mehta obteve a patente relativa a produtos cimentícios altamente duráveis com cinzas, na qual emprega substituições de 5 a 30\% de cimento por CCA, limita o tamanho médio de partículas em 6-8 $4 \mathrm{~m}$ e a superfície específica mínima em $20 \mathrm{~m}^{2} / \mathrm{g}$. Empregando cimento Portland, estuda argamassas e concretos até a idade de 28 dias com relação à resistência à compressão e permeabilidade.

Zhang e Malhotra, em 1996, estudam concreto de alto desempenho com CCA como adição, apresentando resultados das propriedades do concreto fresco com relações água-aglomerante de 0,31 - 0,4 - 0,5. Para a primeira e última relação águacimento, avaliam concreto com $10 \%$ de substituição de cimento por CCA. Já para a segunda, estudam 0, 5, 8, 10 e 15\% de substituição. Os autores também apresentam as propriedades do concreto no estado endurecido de concretos com relação águaaglomerante de 0,4 e 19\% de substituição de cimento por CCA.

Santos, S. (1997), em sua dissertação, faz um estudo de viabilidade da utilização da cinza da casca de arroz brasileira em concretos e argamassas. Seu trabalho mostrou que a CCA tem potencial econômico para ser utilizada como adição.

Em 2000, Sensale apresenta sua tese sobre propriedades mecânicas de concretos convencionais e de alta resistência com adição de cinza da casca de arroz.

Liborio, Souza e Batista (2001) patentearam o processo de extração da sílica contida na casca e na planta de arroz no Brasil. Em 2003, Costenaro faz uma 
comparação entre diversas pozolanas, entre elas a cinza da casca de arroz e a sílica branca da casca de arroz obtida pelo processo acima citado.

Dafico (2001) estuda a dosagem do concreto de alto desempenho utilizando pozolanas provenientes da casca de arroz do sul do Brasil.

Nehdi, Duquette, Damatty (2003) verificaram que o consumo de água de todas as suas amostras produzidas com diferentes tipos de cinzas de casca de arroz (variaram a proporção, a procedência e a forma de combustão da adição de CCA) foi menor comparado ao da amostra confeccionada com sílica de ferro-silício.

Prudêncio, Santos e Dafico (2003) apresentam na Coletânea Habitare uma revisão sobre CCA, incluindo processos de queima e tratamentos realizados para obtenção da sílica branca da casca de arroz.

Em 2004, Fagury e Liborio apresentam um artigo com considerações sobre a utilização das cinzas da casca de arroz residual de termoelétricas como adição em concretos para estruturas costeiras nas Jornadas Sud-Americanas de Ingeniería Estructural em Mendoza.

Recentemente, Chandrasekhar et al. (2005) faz uma revisão sobre processos de queima, aplicações e propriedades da CCA. O trabalho traz informações sobre tratamentos ácidos a que as cinzas podem ser submetidas.

Em relação aos estudos sobre CCA no Brasil, eles estão concentrados em três pólos principais: Rio Grande do Sul (destaque para a Professora Dal Molin e colaboradores), Santa Catarina (equipe do Professor Prudêncio) e São Paulo (Professor Liborio e colaboradores). O desenvolvimento dos trabalhos se deu mais 
nesta e na última década com avanços especialmente na área de queima e tratamento da cinza.

No Brasil, a primeira usina termelétrica, usando cascas de arroz como combustível, foi implantada em 1996 no Rio Grande do Sul, segundo consta no relatório elaborado para o Ministério de Ciência e Tecnologia, dentro do projeto BRA/95/G31, sob o contrato de $n^{\circ}$ 99/117, com o Programa das Nações Unidas para o Desenvolvimento - PNUD, com potência instalada de $2 \mathrm{MW}$ e custo de cerca de $\mathrm{R} \$ 2$ milhões. A energia gerada é suficiente para o consumo de três mil famílias. A produção abastece toda a demanda da indústria que beneficia mensalmente 300 mil sacas de arroz em casca. A energia excedente é negociada com a concessionária operadora da região (FAGURY e LIBORIO; 2004).

\subsection{GENERALIDADES}

São diversas as pesquisas que abordam a utilização da cinza de casca de arroz com resultados mostrando o excelente potencial do material como pozolana. Apesar disto, estas cinzas não têm sido utilizadas para produção de concreto e argamassas tanto no Brasil quanto no exterior. Segundo Prudêncio, Santos e Dafico (2003), isto pode ser atribuído ao fato de que as cinzas geralmente possuem teores elevados de carbono (acima de 5\%), produzindo uma coloração cinza-escura no concreto, como a que pode ser observada na Figura 35, pouco aceita no mercado.

De acordo com Ferreira, Dal Molin e Caten (1999), a cinza de casca de arroz tem área específica de $50 \mathrm{~m}^{2} / \mathrm{g}$ a $100 \mathrm{~m}^{2} / \mathrm{g}$, tamanho médio das partículas de $45 \mu \mathrm{m}$ e teor de sílica em torno de $90 \%$. No entanto, dependendo do processo de 
calcinação e da temperatura envolvida, o material pode apresentar uma área específica de $3,5 \mathrm{~m}^{2} / \mathrm{g}$ a $20 \mathrm{~m}^{2} / \mathrm{g}$.

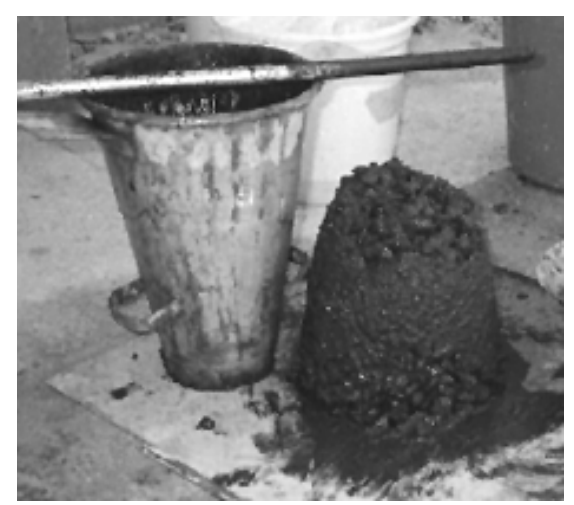

Figura 35: Aspecto do concreto fresco confeccionado com cinza da casca de arroz. Fonte: Prudêncio, Santos e Dafico (2003).

Apesar de ser possível substituir mais de $70 \%$ do cimento do concreto por CCA, basta entre $10 \%$ e $20 \%$ de substituição para que o concreto se beneficie com um aumento de resistência mecânica e uma extraordinária diminuição da permeabilidade frente aos agentes agressivos (cloretos, sulfatos, $\mathrm{CO}_{2}$, etc.), sem que isto acarrete em nenhum efeito adverso ao material. Além disso, misturas de cimento Portland com apenas $10 \%$ de CCA têm-se mostrado efetivas no combate à reação álcali-agregado, que é expansiva e deletéria ao concreto (MEHTA; 1992).

Em relação à resistência à compressão, em sua dissertação, Costenaro (2003) comparou alguns tipos de sílicas ativas. Entre as misturas executadas por ela, o resultado para um traço 1:3,5 e relação água-aglomerante de 0,28 é mostrado na Figura 36. Observa-se que a cinza da casca de arroz obteve resultado similar, um pouco inferior, aos das demais sílicas e bastante positivo em relação ao concreto de referência sem nenhuma adição. Para Zhang, Lastra e Malhotra (1996), que obtiveram 
resultados semelhantes, a CCA tem um desempenho inferior às outras sílicas por causa do maior tamanho de suas partículas.

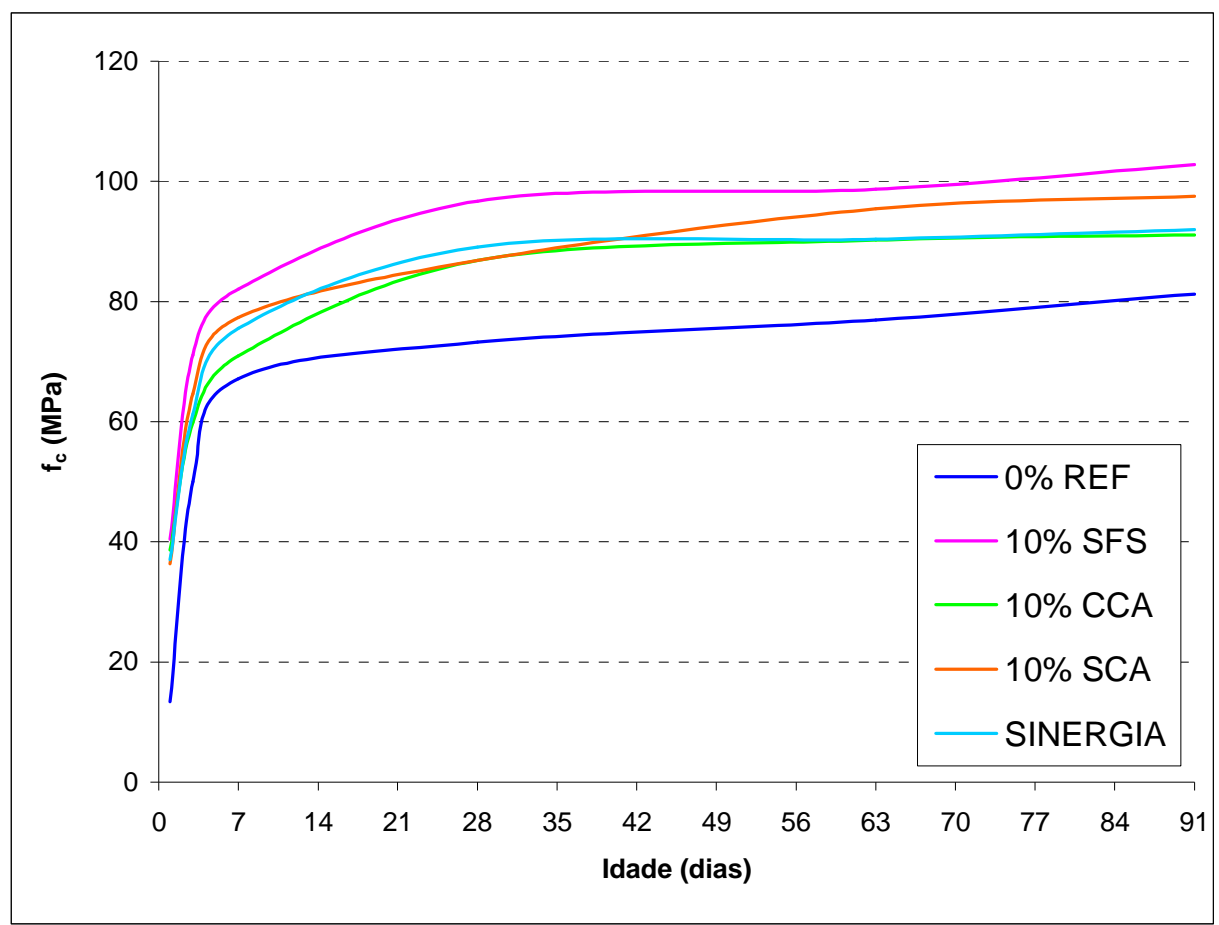

Figura 36: Diagrama de resistência à compressão x tempo; traço 1:3,5:0,28. Fonte: Costenaro, 2003.

Diversos estudos (MALHOTRA e MEHTA, 1996; ZHANG e MALHOTRA, 1996; RODRIGUEZ e DAL MOLIN, 1999; SENSALE, 2000) demonstraram, porém, que o ganho de resistência em relação às misturas sem adição de CCA não acontece em todas as idades, e sim a partir da primeira semana. Antes disso, as resistências são inferiores às alcançadas pelos concretos de referência, como pode ser observado na Tabela 8. Na maioria dos trabalhos com cinzas de diversas origens e tratamentos, este ganho de resistência em relação à referencia não é grande, algumas vezes apresentam, até mesmo, valores iguais. Alguns trabalhos que ensaiaram concretos com idades avançadas (148, 180 dias) à compressão mostraram que, mesmo nestas idades, continuava havendo acréscimo de resistência. 
Tabela 8: Resistência à compressão de concretos com adição de CCA.

Fonte: Malhotra e Mehta (1996); Zhang e Malhotra (1996).

\begin{tabular}{cccccccc}
\hline CCA (\%) & \multirow{2}{*}{ a/agl } & 1 dia & 3 dias & 7 dias & 28 dias & 90 dias & 180 dias \\
\hline 0 & 0,4 & 20,9 & 25,5 & 28,9 & 36,4 & 42,5 & 44,2 \\
\hline 10 & 0,4 & 22,1 & 26,2 & 31,1 & 38,6 & 47,0 & 48,3 \\
\hline
\end{tabular}

Em relação ao teor de CCA nas misturas, percebe-se que nas primeiras idades, quanto maior é o teor de CCA, menor a resistência à compressão, porém com maior idade o comportamento se inverte, quanto maior a teor de CCA, maior a resistência à compressão. Isto deve acontecer pela diminuição de $\mathrm{C}_{3} \mathrm{~S}$ do cimento Portland por causa da substituição por material pozolânico (CCA) e, como a reação pozolânica é mais lenta, a resistência demora mais para se desenvolver. Na maioria dos ensaios com misturas com relações água-aglomerante variando de 0,3 a 0,6 , as resistências são superiores nas idades mais avançadas. Percebe-se analisando os resultados de vários autores que o fator que mais influencia a resistência é o processo de queima pelo qual a cinza foi submetida e sua finura.

Comparando a resistência de concretos com adição de CCA e as correspondentes pastas, Zhang, Lastra e Malhotra (1996) perceberam que a cinza contribui para a resistência das pastas e dos concretos de diferentes maneiras e magnitudes. A resistência de pastas com CCA são similares ou inferiores às pastas de controle, enquanto que a resistência dos concretos com a cinza são maiores que a dos concretos de controle. Isto indica que o aumento na resistência dos concretos com CCA se deve, primordialmente, a melhoria na zona de transição.

Malhotra e Mehta (1996) afirmam que a ação da CCA no concreto depende das características mineralógicas e granulométricas, não sendo tão importante a composição química da cinza. Sensale (2000) organizou a composição química de várias cinzas da casca de arroz, sendo a principal diferença entre elas a temperatura a 
que foram submetidas. Observa-se que os teores de sílica estão entre 87 e 95\% em todas as amostras. Os álcalis $\mathrm{K}_{2} \mathrm{O}$ e $\mathrm{Na}_{2} \mathrm{O}$ ocorrem como principais impurezas atingindo valores de até $6,5 \%$. Outras impurezas como o $\mathrm{CaO}$ e $\mathrm{MgO}$ estão presentes em todas as cinzas, mas em teores não superiores a $2 \%$. A causa das diferenças pode estar tanto na origem, quanto na utilização de fertilizantes agrícolas. As cinzas, dependendo do solo e fertilizantes utilizados, podem apresentar uma quantidade alta de $\mathrm{K}_{2} \mathrm{O}$ e $\mathrm{Na}_{2} \mathrm{O}$, que são as principais impurezas.

Tabela 9: Composição química de diversas CCA.

Fonte: Sensale (2000), Sensale (2006) complementada pela autora.

\begin{tabular}{|c|c|c|c|c|c|c|c|c|c|}
\hline $\begin{array}{l}\text { AUTOR (ANO) } \\
\text { TEMPERATURA }\end{array}$ & $\mathrm{SiO}_{2}$ & $\mathrm{Al}_{2} \mathrm{O}_{3}$ & $\mathrm{Fe}_{2} \mathrm{O}_{3}$ & $\mathrm{CaO}$ & $\mathrm{MgO}$ & $\mathrm{SO}_{3}$ & $\mathrm{Na}_{2} \mathrm{O}$ & $\mathrm{K}_{2} \mathrm{O}$ & $\begin{array}{c}\text { Perda } \\
\text { ao } \\
\text { fogo } \\
\end{array}$ \\
\hline $\begin{array}{l}\text { COOK }(1976) \\
450^{\circ} \mathrm{C}\end{array}$ & 93,15 & 0,41 & 0,20 & 0,41 & 0,45 & ND & 0,08 & 2,31 & 2,77 \\
\hline $\begin{array}{l}\text { SALAS (1986) } \\
1000^{\circ} \mathrm{C}\end{array}$ & 91,26 & 0,94 & 0,37 & 2,15 & 0,88 & ND & ND & ND & ND \\
\hline $\begin{array}{l}\text { CINCOTTO (1989) } \\
500-600^{\circ} \mathrm{C}\end{array}$ & 94,7 & 0,09 & 1,46 & 0,99 & 0,95 & 0,21 & 0,04 & 1,75 & 7,29 \\
\hline $\begin{array}{l}\text { GUEGERT (1989) } \\
\text { Sem controle }\end{array}$ & 93,11 & 0,92 & 0,40 & 0,52 & 0,85 & ND & 0,12 & 1,12 & ND \\
\hline $\begin{array}{l}\text { SANTOS (1997) } \\
\text { Sem controle }\end{array}$ & $\begin{array}{l}90,32 \\
95,12 \\
93,50 \\
95,64\end{array}$ & $\begin{array}{l}1,36 \\
1,42 \\
1,90 \\
1,40 \\
\end{array}$ & $\begin{array}{l}0,85 \\
1,01 \\
0,98 \\
0,95\end{array}$ & $\begin{array}{l}1,67 \\
1,58 \\
1,17 \\
1,30 \\
\end{array}$ & $\begin{array}{l}0,50 \\
0,37 \\
0,63 \\
0,43\end{array}$ & $\begin{array}{l}0,04 \\
0,00 \\
0,03 \\
0,00 \\
\end{array}$ & $\begin{array}{l}0,00 \\
0,00 \\
0,00 \\
0,00\end{array}$ & $\begin{array}{l}0,73 \\
0,44 \\
0,66 \\
0,47\end{array}$ & $\begin{array}{c}11,35 \\
9,87 \\
4,44 \\
9,18\end{array}$ \\
\hline $\begin{array}{l}\text { SUGITA et al (1992) } \\
60^{\circ} \mathrm{C}\end{array}$ & 90,00 & 0,10 & 0,40 & 0,40 & 0,3 & ND & 0,06 & 2,41 & 4,2 \\
\hline $\begin{array}{l}\text { SILVEIRA (1996) } \\
560^{\circ} \mathrm{C}\end{array}$ & 93,00 & ND & 0,05 & 0,59 & 1,90 & ND & 0,62 & 3,40 & ND \\
\hline $\begin{array}{l}\text { HWANG e WU (1989) } \\
400^{\circ} \mathrm{C}\end{array}$ & 88,05 & ND & 0,74 & 2,02 & 1,13 & 0,83 & 0,76 & 6,48 & ND \\
\hline $\begin{array}{l}\text { HWANG e WU (1989) } \\
60^{\circ} \mathrm{C}\end{array}$ & 88,67 & ND & 0,46 & 1,73 & 0,84 & 0,81 & 1,09 & 6,41 & ND \\
\hline $\begin{array}{l}\text { HWANG e WU (1989) } \\
700^{\circ} \mathrm{C}\end{array}$ & 92,15 & ND & 0,0 & 1,60 & 0,51 & 0,79 & 0,99 & 3,94 & ND \\
\hline $\begin{array}{l}\text { HWANG e WU (1989) } \\
100^{\circ} \mathrm{C}\end{array}$ & 95,48 & ND & 0,43 & 1,16 & 0,59 & 0,09 & 0,73 & 1,28 & ND \\
\hline $\begin{array}{l}\text { SENSALE (2006) } \\
\text { De termoelétrica }\end{array}$ & 87,2 & 0,15 & 0,16 & 0,55 & 0,35 & 0,32 & 1,12 & 3,60 & 6,55 \\
\hline $\begin{array}{l}\text { SENSALE (2006) } \\
\text { queima controlada }\end{array}$ & 88 & --- & 0,10 & 0,80 & 0,20 & --- & 0,70 & 2,20 & 8,10 \\
\hline $\begin{array}{l}\text { CCA DESTE } \\
1000^{\circ} \mathrm{C} \text { termoelétrica }\end{array}$ & 88,37 & 0,30 & 0,25 & 0,76 & 0,79 & ND & 0,18 & 1,02 & 7,44 \\
\hline
\end{tabular}


A quantidade de carbono na cinza da casca de arroz influencia o tempo de pega. Para misturas de cal e CCA, Cook e Suwanvitaya (1981) perceberam que quanto maior a porcentagem de carbono existente, maiores eram os tempos de início e fim de pega, já para misturas de cimento Portland e CCA, ambos diminuíam conforme Tabela 10.

Tabela 10: Comparativo de tempos de pega de misturas com diferentes teores de CCA. Fonte: Cook e Suwanvitaya (1981).

\begin{tabular}{|c|c|c|c|c|c|}
\hline \multirow{2}{*}{$\begin{array}{l}\text { Cimento } \\
\text { Portland }\end{array}$} & \multirow{2}{*}{ Cal } & \multirow{2}{*}{ CCA } & \multirow{2}{*}{$\begin{array}{c}\text { \% carbono } \\
\text { na CCA }\end{array}$} & \multicolumn{2}{|c|}{ Tempo de pega (mm) } \\
\hline & & & & Início & Fim \\
\hline 0 & 20 & 80 & 14 & 135 & 420 \\
\hline 0 & 20 & 80 & 42 & 265 & 675 \\
\hline 0 & 40 & 60 & 14 & 165 & 330 \\
\hline 0 & 40 & 60 & 42 & 270 & 690 \\
\hline 60 & 0 & 40 & 14 & " & 110 \\
\hline 60 & 0 & 40 & 42 & 35 & 50 \\
\hline 80 & 0 & 20 & 14 & 120 & 190 \\
\hline 80 & 0 & 20 & 42 & 50 & 170 \\
\hline 100 & 0 & 0 & --- & 40 & 80 \\
\hline
\end{tabular}

As propriedades da cinza da casca de arroz também dependem da origem do cereal. Em seus estudos, Mehta (1994) mostra que cascas de arroz de diferentes origens, queimadas com controle de combustão pelo mesmo método (o por ele patenteado em 1978) fornece cinzas com propriedades bastante distintas. A área específica, por exemplo, variou de 24,3 a $99,2 \mathrm{~m}^{2} / \mathrm{g}$.

Segundo Malhotra e Mehta (1996), as variações relativas ao tempo em que a reação pozolânica se inicia são influenciadas pelas suas propriedades físicas, em particular pela sua finura, além das condições de formação e da proporção da cinza em relação a de cimento e/ou cal.

Em relação ao consumo de água, conforme Mehta e Monteiro (1994), para uma dada consistência de concreto, o emprego de materiais de área específica muito alta, tais como as cinzas da casca de arroz, tendem a apresentar necessidade maior de 
água, pois a área específica é predominantemente controlada pelos microporos. A solução para compensar a maior demanda de água pelas minúsculas partículas pode estar na utilização de superplastificantes. A aplicação deste tipo de aditivo torna-se essencial para que a cinza desenvolva todo o seu potencial físico-químico como pozolana. O teor de aditivo incorporador de ar e superplastificante também é relativamente elevado com a presença da CCA, e este aumento é proporcional ao teor da cinza. Apesar deste inconveniente, a CCA apresenta tempos de pega maiores que misturas com sílica de ferro-silício e de controle (ZHANG e MALHOTRA, 1996).

Chandra (1997) comenta que a reologia, a cinética da hidratação, o desenvolvimento da microestrutura e a retração química e física são influenciadas pelas técnicas de mistura ou adições de cinzas, escória, sílica de ferro-silício, cinza da casca de arroz, e que o efeito de floculação da sílica ativa em pastas de cimento pode levar a uma reação álcali-sílica. O autor menciona que ainda não há nada que se possa fazer para prevenção desta floculação. Esta cria uma distribuição desigual do material na água e isso leva a uma hidratação heterogênea do concreto que, conseqüentemente, aumenta o desvio padrão de todos os ensaios realizados com compósitos contendo estas adições, especialmente as muito finas, como é o caso da sílica de ferro-silício e da cinza de casca de arroz.

Segundo Mehta e Monteiro (1994), o calor de hidratação total produzido pelas reações pozolânicas envolvendo adições minerias é considerado como a metade do valor médio produzido pela hidratação do cimento Portland. Hwang e Wu (1989), apresentam a evolução da curva de calor de pastas com CCA. Seus resultados (Figura 37) mostram que as curvas das pastas com e sem CCA são similares, com o primeiro pico maior que o segundo. Os autores concluem que, para uma mesma relação água- 
cimento, o calor de hidratação diminui com o aumento do teor de CCA. Zhang e Malhotra (1996) determinaram que a temperatura máxima de um concreto com 15\% de adição de CCA ocorre depois de 16,3h do início da hidratação, enquanto que quando a adição é a sílica de ferro-silício, o tempo é de 18,9h e para o concreto de controle é $19,7 \mathrm{~h}$.

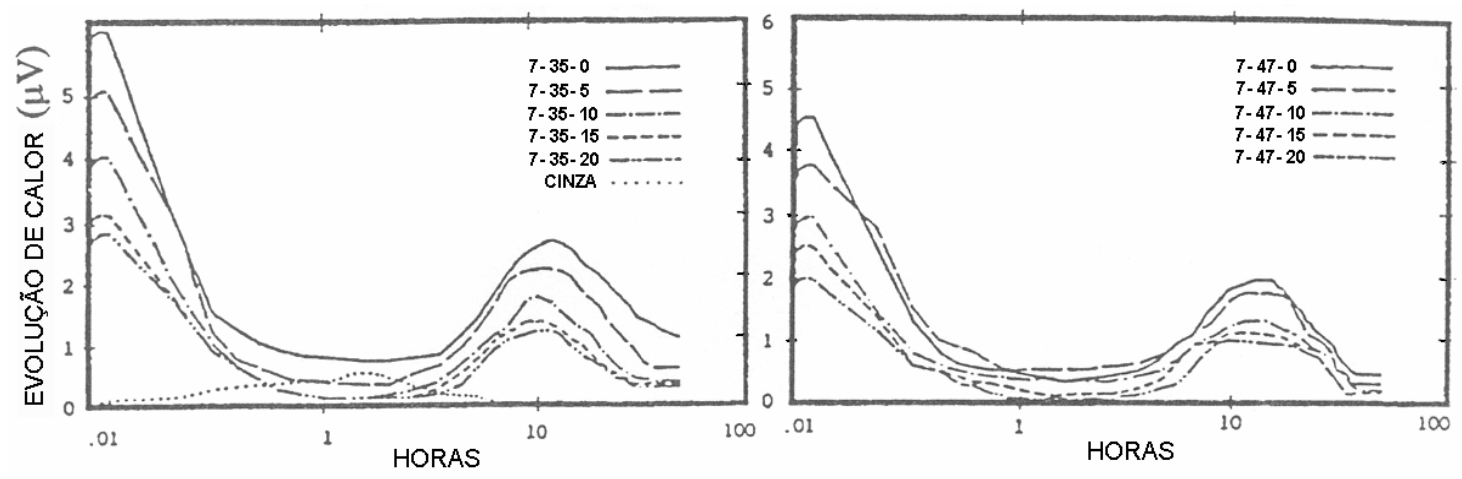

Figura 37: Evolução da curva de calor em pastas de cimento e CCA. Legenda: idade - relação a/c (\%) - teor de CCA (\%).

Fonte: Hwang e Wu (1989).

Mehta e Folliard (1992) estudam o comportamento de uma cinza amorfa com área específica de $50-60 \mathrm{~m}^{2} / \mathrm{g}$ por absorção de nitrogênio e tamanho médio das partículas igual a $8 \mu \mathrm{m}$ em concretos. Os autores detectaram que, em misturas com relação água-aglomerante igual a 0,33, o concreto com $13 \%$ de CCA se mostrou mais resistente à solução de $\mathrm{HCl}$ que o concreto de controle sem cinza. Segundo os autores, considera-se $25 \%$ de perda de massa como o valor máximo aceitável. O concreto com CCA não atingiu o limite, enquanto que o de controle ultrapassou o limite na $10^{\underline{a}}$ semana, conforme Figura 38. A melhora da resistência a ácidos do concreto com CCA poderia ser atribuída à redução da permeabilidade. Com a mesma cinza foram executadas amostras de argamassas com quantidades de água diferentes, mas de mesma consistência. Estas foram então submetidas a uma solução de sulfato de sódio. 
No final de 16 semanas, foi constatada uma redução de $82 \%$ na expansão da mistura contendo CCA, conforme se pode observar na Figura 39.

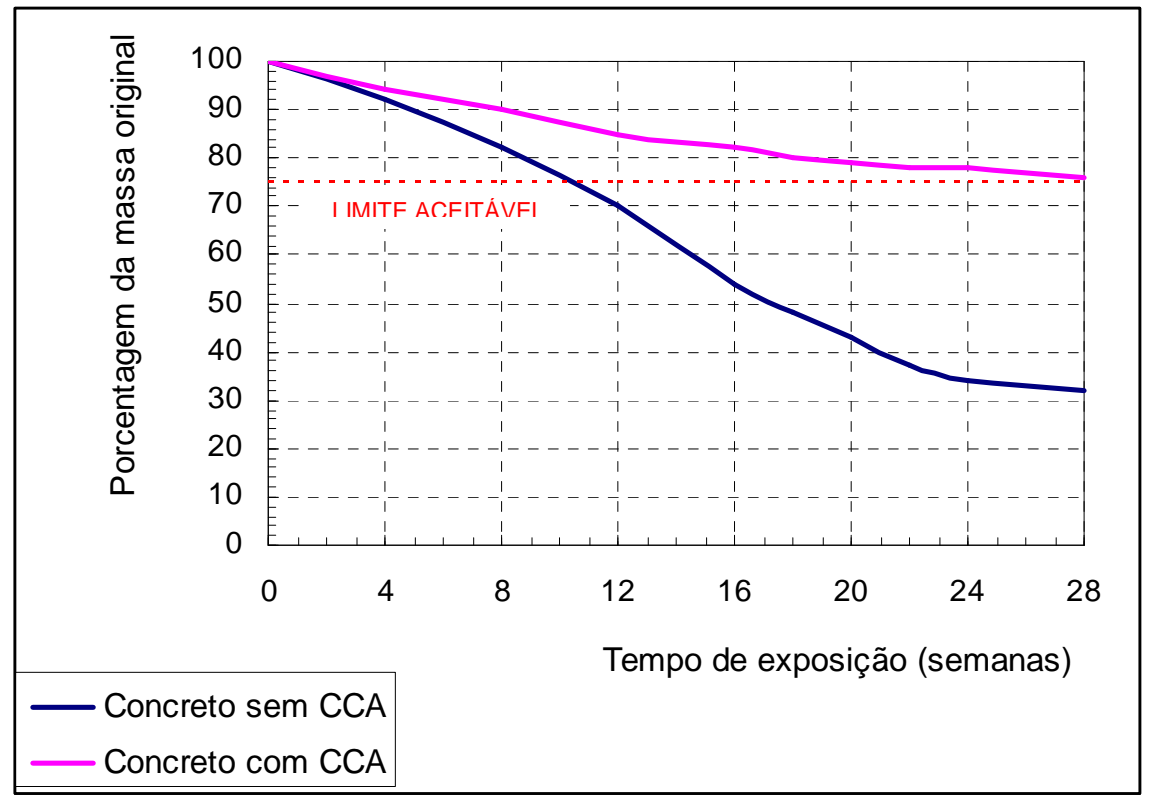

Figura 38: Gráfico mostrando o comportamento da CCA frente à ação ácida. Fonte: Mehta e Folliard (1992).

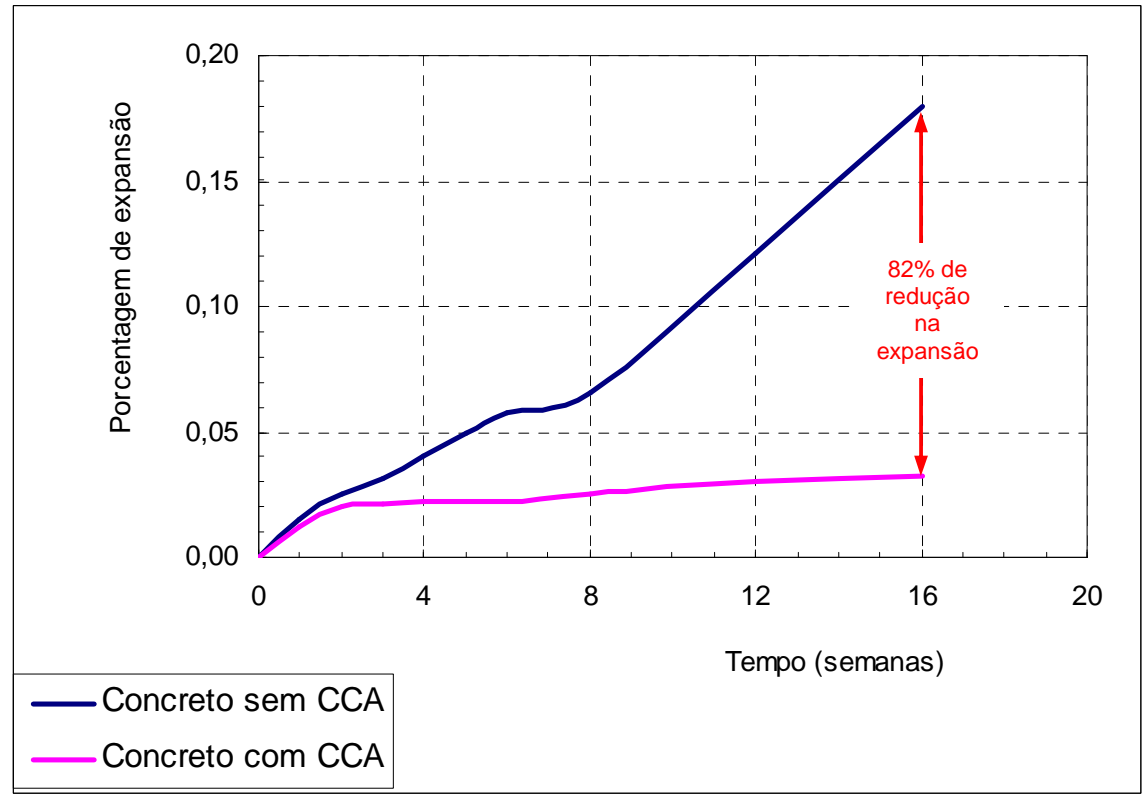

Figura 39: Gráfico mostrando a expansão de argamassas frente a sulfatos. Fonte: Mehta e Folliard (1992). 
Em relação à resistência ao gelo-degelo, Mehta e Folliard (1992), fazem um estudo sobre a eficiência da sílica de ferro-silício (SFS) e cinza da casca de arroz em concretos com base na ASTM C 666. A CCA utilizada nesta pesquisa tem alto teor de carbono (15\%). Foram moldadas três misturas, uma com 15\% de CCA, uma com $15 \%$ de SFS e outra sem adições minerais (REF) com relações água-aglomerante de 0,30 e 0,35 . Foi utilizado superplastificante para se obter abatimentos de $150-200 \mathrm{~mm}$, mas não foi aplicado aditivos incorporadores de ar. A Figura 40 mostra o fator de durabilidade para cada mistura. Os concretos com CCA foram os únicos a suportar 300 ciclos e, assim, atender o critério que especifica que o fator de durabilidade deve ser de no mínimo 60. A SFS apresentou comportamento ruim que, segundo os autores, pode ser atribuído à impermeabilidade da pasta, que prejudica o movimento da água. Em compensação, a CCA apresentou um comportamento ótimo, o que poderia ser conseqüencia da estrutura mais porosa dos produtos produzidos pela sua reação, que permite a evasão de parte da água de congelamento do concreto, reduzindo a pressão interna.

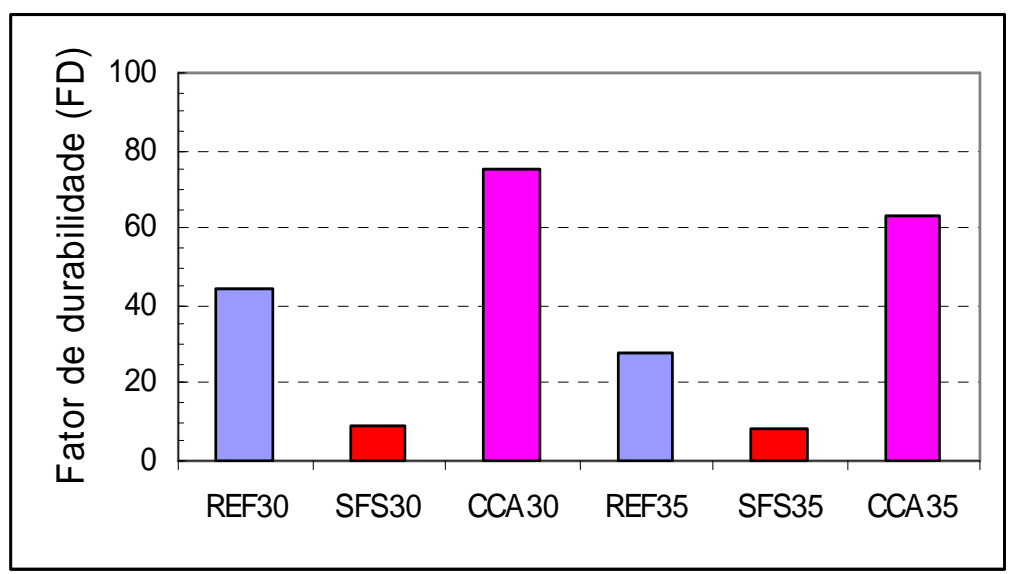

Figura 40: Fator de durabilidade de concretos sujeitos a 300 ciclos de gelo-degelo. Fonte: Mehta e Folliard (1992). 


\subsection{INFLUÊNCIA DA QUEIMA}

A temperatura é uma das variáveis que mais vai afetar as características físicas e químicas da cinza, tanto pela sua magnitude quanto pelo tempo de exposição a que a amostra é submetida.

Mehta (1992) mostra que quando a temperatura de queima da casca de arroz é baixa (400 a $600^{\circ} \mathrm{C}$ ) e o tempo de exposição à temperatura é pequeno, a sílica contida na cinza é amorfa. A cinza nestas condições apresenta forma angular, estrutura altamente celular e superfície específica elevada, de 40 a $110 \mathrm{~m}^{2} / \mathrm{g}$ (por absorção de nitrogênio), e diâmetro médio geralmente inferior a $45 \mu \mathrm{m}$.

A queima sem controle da casca de arroz fornece como produto a CCA rica em sílica (teor maior que 90\%), normalmente em forma cristalina. Se submetida á queima controlada, a sílica é amorfa, caracterizada por uma alta reatividade (CHANDRASEKHAR et al., 2005).

As três fases polimórficas da sílica cristalina na pressão atmosférica são quartzo $\alpha$, quartzo $\beta$, tridimiita e cristobalita. A forma mais estável na temperatura ambiente é o quartzo $\alpha$, que se transforma em quartzo $\beta$ à $573^{\circ}$ e permanece estável até $870^{\circ}$. Entre $870^{\circ} \mathrm{C}$ e $1470^{\circ} \mathrm{C}$ persiste a forma tridimita e de $1470^{\circ} \mathrm{C}$ até $1713^{\circ} \mathrm{C}$ ela se modifica para a cristobalita. Acima de $1713^{\circ} \mathrm{C}$ ocorre a fusão da sílica (ERNEST apud DAFICO; 2001).

A estrutura da sílica vítrea é metaestável e, portanto, tem a tendência de mudar lentamente para a forma cristalina, de menor energia livre, que é mais estável. Se a temperatura for mantida acima de $870^{\circ} \mathrm{C}$ por um longo período, a sílica vítrea se cristaliza em cristobalita e, eventualmente, em tridimita se as condições forem 
favoráveis, isto é, na presença de íons catalisadores (principalmente íons alcalinos), processo este conhecido por devitrificação (WORRAL apud DEFICO; 2001).

A queima parcial da casca de arroz causa a decomposição da parte orgânica e quebra da ligação com a Si (CHANDRASEKHAR et al., 2005) gerando uma cinza com certo teor de carbono e, por isso, de cor preta. Quando inteiramente queimada, resulta numa cinza de cor acinzentada, branca ou púrpura, dependendo das impurezas presentes e das condições de queima.

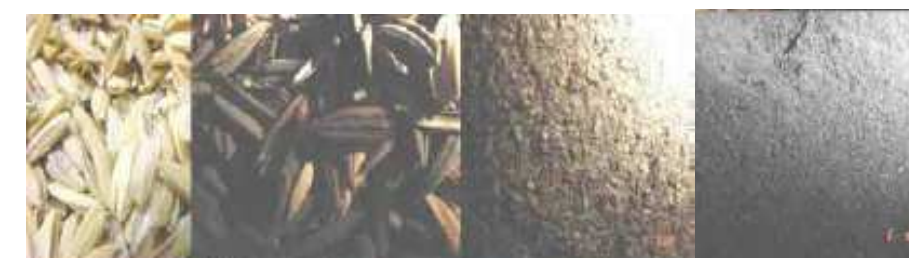

Figura 41: Etapas do processo de fabricação de sílica.

Fonte: Silva, F. G. (2004).

Mehta (1992) atribui à alta reatividade da CCA queimada controladamente às propriedades das partículas de serem bastante porosas e, assim, não necessitam de um longo período de indução para ativação da superfície em meio alcalino. A conseqüência disto, é que a CCA reage rapidamente com o hidróxido de cálcio formando C-S-H, ou seja, a reação não é tão lenta quanto se espera de uma reação pozolânica comum. Segundo o autor, quando a CCA é altamente pozolânica, o período de cura pode ser reduzido para se atingir as resistências mecânicas requeridas em comparação com outras adições (Figura 42).

Com relação às condições de queima, a maioria dos trabalhos a respeito concordam com Mehta que diz que as temperaturas devem situar-se entre 500 e $700^{\circ} \mathrm{C}$ para não haver cristalização da sílica. 


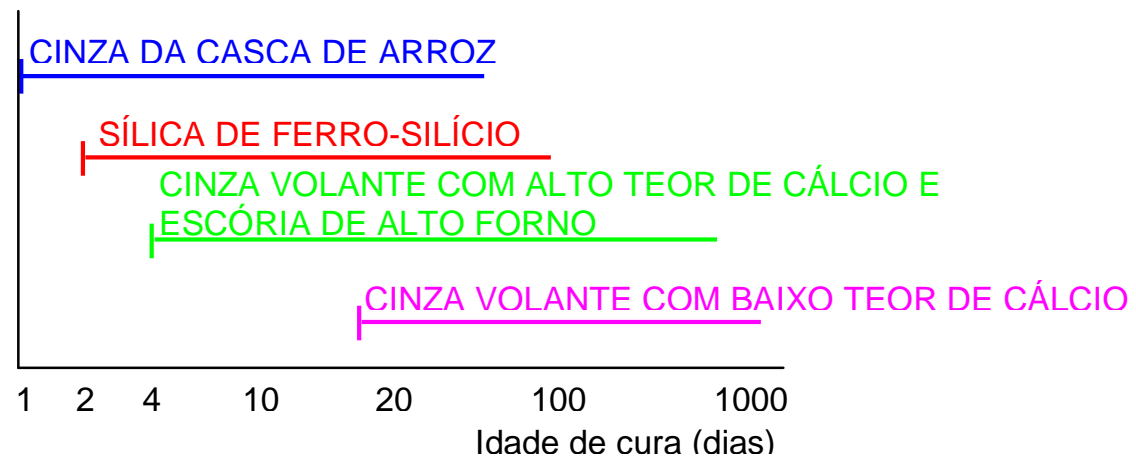

Figura 42: Período efetivo de contribuição na resistência. Adaptado de Mehta (1992).

\subsection{INFLUÊNCIA DA MOAGEM}

O grau de moagem é um fator importante, pois modifica propriedades físicas da cinza da casca de arroz, como a superfície específica e finura. Estas propriedades estão diretamente ligadas à trabalhabilidade. No caso das CCA, a moagem torna as partículas, que são originalmente aciculares, mais próximas ao formato esférico (Figura 43).

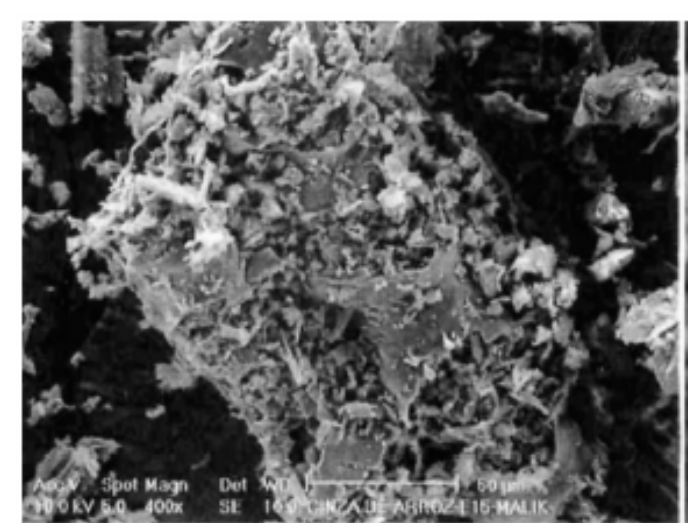

(a)

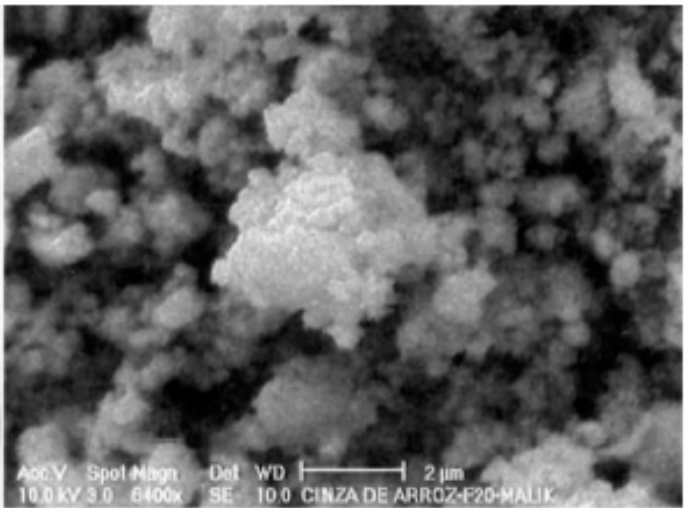

(b)

Figura 43: MEV com o tamanho e formato das partículas de CCA depois da moagem. (a) Tempo de moagem de 15min; (b) Tempo de moagem de $20 \mathrm{~h}$. Fonte: Santos, 1997. 
Faria e Recena (1990) estudaram a alteração na superfície específica em função do tempo de moagem. $O$ tempo de moagem variou de 3 a 70 minutos. Medindose a superfície específica das amostras, os autores concluíram que ela se apresenta em ascensão até o tempo de 30 minutos, depois disto há diminuição. Guedert (1989), num estudo similar, com tempos de 1, 2, 4 e 8 horas encontrou superfícies específicas e pozolanicidade cada vez maiores com o tempo de moagem. Santos (1997) encontrou os resultados expostos na Tabela 11 que demonstram um aumento da superfície específica com o aumento do tempo de moagem. Já a pozolanicidade apresentou aumento até 4 horas de moagem, posteriormente apresentou decréscimo. A autora concluiu que o tempo de moagem leva a diferentes áreas específicas e influenciam de forma significativa na atividade pozolânica do material e que existe um tempo de moagem ótimo para que a CCA atinja a máxima pozolanicidade. A partir deste tempo ótimo, há aumento demasiado da área específica, o que pode dificultar a dispersão da pozolana na argamassa. Todavia, esse tempo de moagem ótimo pode ser bastante alto, levando a um consumo muito grande de energia.

Tabela 11: Influência do tempo de moagem na superfície específica e pozolanicidade da CCA.

Fonte: Santos, S. (1997).

\begin{tabular}{lccccccccc}
\hline Tempo de moagem & $15 \mathrm{~min}$ & $30 \mathrm{~min}$ & $1 \mathrm{~h}$ & $2 \mathrm{~h}$ & $4 \mathrm{~h}$ & $6 \mathrm{~h}$ & $8 \mathrm{~h}$ & $10 \mathrm{~h}$ & $20 \mathrm{~h}$ \\
\hline $\begin{array}{l}\text { Superficie Específica } \\
\text { Blaine }\left(\mathrm{m}^{2} / \mathrm{kg}\right)\end{array}$ & 827 & 1087 & 1376 & 1604 & 1614 & 1772 & 2275 & 2589 & 2899 \\
$\begin{array}{l}\text { IAP(\%) } \\
\text { NBR 5752:1992 }\end{array}$ & 62 & 83 & 106 & 113 & 126 & 123 & 119 & 118 & 115 \\
\hline
\end{tabular}

Bui, Hu e Stroeven (2005) ensaiaram concretos com adição de CCA em que variaram a finura do cimento. Concluíram que a finura da cinza, para que o concreto atinja melhores resultados em termos de resistência à compressão, deve estar de acordo com a finura do cimento, isto é, o tamanho médio das partículas do cimento e 
da cinza deve ser distinto a fim de fornecer um aglomerante bem graduado, bem empacotado.

\subsection{SÍLICA BRANCA DA CASCA DE ARROZ}

Quando a queima da casca de arroz se realiza com abundância de oxigênio, obtém-se a sílica da casca de arroz (SCA), que é formada por um pó branco, amorfo, cuja composição varia com a região de plantação de arroz e condições climáticas.

Liborio, Souza e Batista (2001) patentearam um procedimento de obtenção da sílica junto à FAPESP, no qual primeiramente a casca de arroz passa por uma lavagem ácida (solução de ácido clorídrico com concentração de 3 a 5\%) durante 3 dias; seguem-se lavagem em água corrente até que o pH atingir valores entre 6 e 7; depois de seca, a casca é queimada em um forno rotativo pelo período de duas horas a uma temperatura de $300^{\circ} \mathrm{C}$. A cinza obtida é então moída em um moinho de bolas por 45 minutos e recolocada no forno sob temperatura de $600^{\circ} \mathrm{C}$ durante 6 horas (Figura 44). Silva, F. G. (2006) ressalta a importância da constante injeção de oxigênio no forno rotativo e que, com a calcinação a $600^{\circ} \mathrm{C}$, a cinza perde todo o seu conteúdo de carbono tornando-se branca e isenta de materiais orgânicos.
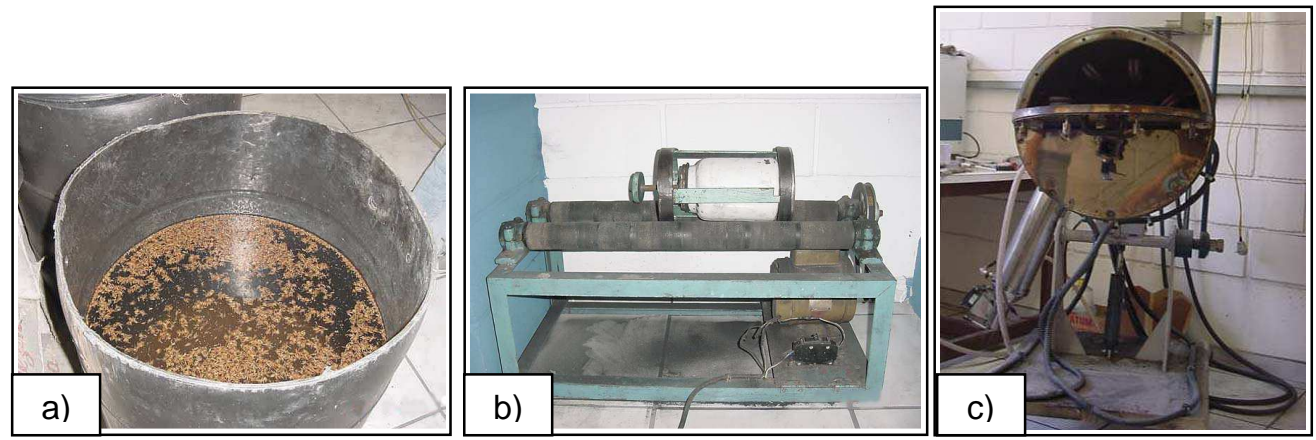

Figura 44: Produção da SCA: a) lavagem ácida, b) moinho de bolas e c) forno.

Fonte: Silva, F. G. (2006). 
Segundo Chandrasekhar (2005), o tratamento ácido não afeta a propriedade amorfa da cinza.

A sílica da casca de arroz obtida pelo procedimento de Liborio, Souza e Batista (2001) é considerada de alta reatividade, com 99,75\% de material pozolânico (método de Chapelle modificado), possui $93,6 \mathrm{~m}^{2} / \mathrm{g}$ de área superficial e massa específica igual a $2,2 \mathrm{~g} / \mathrm{cm}^{3}$. Sua composição química é mostrada na Tabela 12 . Em relação à resistência à compressão do concreto, é inferior a do concreto sem sílica nas primeiras idades, mas superior nas idades mais avançadas. $O$ material apresentou melhora considerável quanto à frente de penetração dos íons cloretos em comparação ao concreto de referência, apesar de ter apresentado valores de absorção por capilaridade similares (SILVA. F.G.; 2006).

Tabela 12: Composição química da SCA.

Fonte: Silva, F. G. (2006).

\begin{tabular}{cc}
\hline CONSTITUINTES & VALORES MEDIOS (\%) \\
\hline $\mathrm{SiO}_{2}$ & 97,53 \\
$\mathrm{Fe}_{2} \mathrm{O}_{3}$ & 0,21 \\
$\mathrm{Al}_{2} \mathrm{O}_{3}$ & $--\cdot$ \\
$\mathrm{CaO}$ & 0,22 \\
$\mathrm{P}_{2} \mathrm{O}_{5}$ & 0,26 \\
$\mathrm{MnO}$ & $--\cdot$ \\
$\mathrm{Na}_{2} \mathrm{O}$ & 0,01 \\
\hline $\mathrm{MgO}$ & $--\cdot$ \\
$\mathrm{K}_{2} \mathrm{O}$ & 0,04 \\
$\mathrm{Cr}_{2} \mathrm{O}_{5}$ & -- \\
\hline $\mathrm{TiO}_{2}$ & 0,02 \\
\hline $\mathrm{Perda}$ ao fogo & 1,72 \\
\hline
\end{tabular}

Dafico (2001) desenvolveu um forno de leito fixo com o objetivo de produzir cinzas de casca de arroz com baixos teores de carbono (cinzas brancas) ou de reduzir os teores de carbono de cinzas já existentes, obtendo cinzas com médios teores de carbono (material de cor cinza). O funcionamento do forno era em duas etapas: a primeira consumia os voláteis e a segunda o oxigênio do ar era consumido pelo 
carbono fixo. Existia um mecanismo de injeção de ar. O processo resultou em uma cinza não homogênea, com a coloração variando do branco ao preto.

Weber (2001) desenvolveu um forno piloto, com leito fixo, intermitente, com capacidade para $1 \mathrm{~m}^{3}$ de material, na tentativa de produzir a cinza de casca de arroz com baixo teor de carbono em escala comercial. Porém, o material produzido apresentou-se muito heterogêneo devido à dificuldade de aeração do material, essencial para uma boa queima. A coloração da cinza também variou de branca a preta.

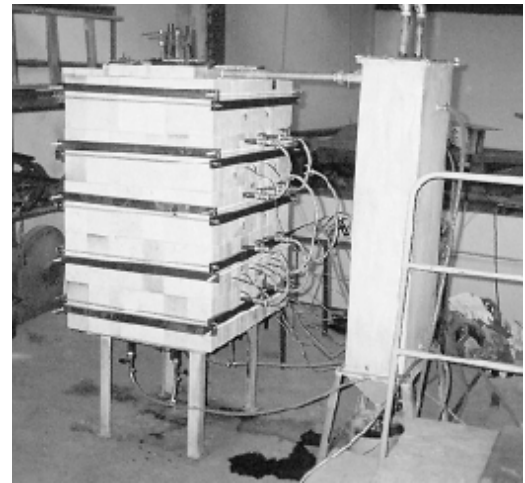

(a)

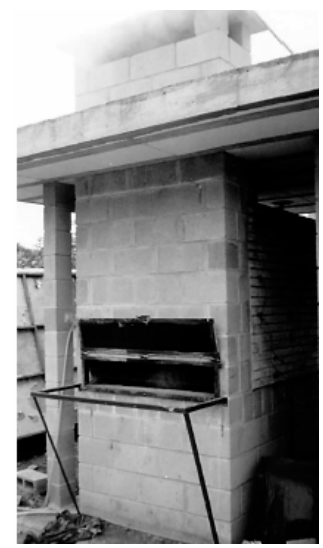

(b)

Figura 45: Fornos para fabricação de sílica branca da casca de arroz.

(a) Dafico (2001); (b) Weber (2001).

Fonte: Prudêncio, Santos e Dafico (2003).

A partir das experiências de Dafico e Weber, Santos, S. está desenvolvendo um forno rotativo para produzir um material homogêneo (Figura 46).

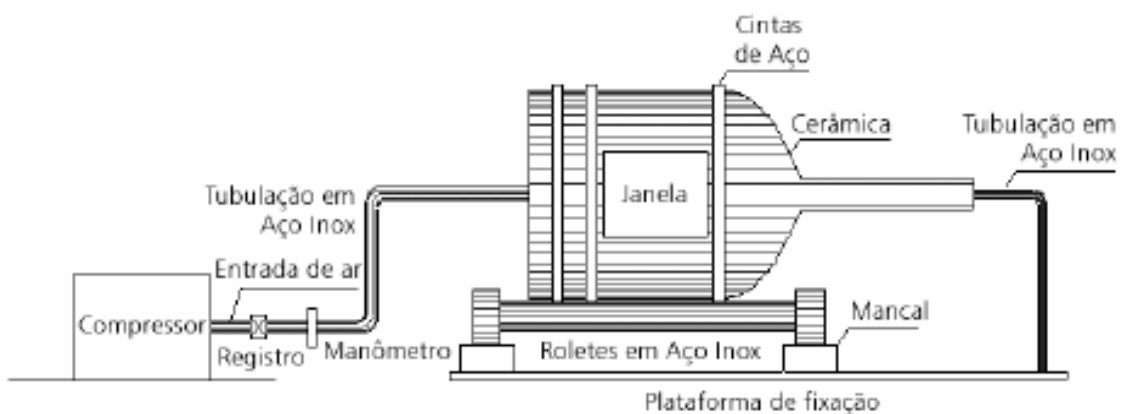

Figura 46: Forno rotativo a ser estudado por Santos, S. Fonte: Prudêncio, Santos e Dafico (2003). 


\subsection{POTENCIAL ECONÔMICO}

Do ponto de vista econômico a cinza da casca de arroz tem um futuro promissor. Em 2003, o Brasil foi o 9 maior produtor mundial de arroz, colhendo mais de 10 milhões de toneladas. A previsão para a safra de arroz, segundo dados do IBGE no ano de 2005 é mais de 13 milhões de toneladas. A cinza representa aproximadamente 4\% em peso do arroz em casca. Isto significa que poderiam ser produzidas 531.193 toneladas de CCA.

Mudanças ocorridas ao longo do tempo no processo de beneficiamento do arroz obrigaram as próprias usinas a gerarem energia para a secagem do produto, o que pode ser feito com a própria casca do arroz em vez da utilização de madeira, que é mais custosa e ecologicamente incorreta. Um combustível comumente empregado na queima do arroz é o diesel. A substituição total ou parcial deste combustível pela casca de arroz traz a vantagem da redução da quantidade de um material fóssil não renovável. O valor energético da casca de arroz é aproximadamente $14 \mathrm{MJ} / \mathrm{kg}$, o que significa que 1 tonelada de casca é equivalente a $0,48 t f$ de carvão ou $0,36 t f$ de óleo combustível. Além disso, a casca de arroz é um produto renovável, o que faz com que a sua utilização esteja em acordo com os princípios da sustentabilidade.

O processo de combustão da casca de arroz gera um grande volume de resíduos sem valor comercial e que podem se tornar agentes poluidores do ar e da água. Para minimizar o problema, órgãos ambientais como o FATMA de Santa Catarina têm exigido a instalação de um sistema constituído de silo separador e decantação para reter a cinza junto às beneficiadoras.

A utilização da casca de arroz como combustível é duplamente vantajosa, pois além de poupar a natureza com a substituição de combustíveis comuns pela 
casca, como acima mencionado, ainda provoca menos danos à atmosfera. Isto por que segundo Rovere (2003), a deposição da casca de arroz em aterros sanitários resulta em emissões de metano para a atmosfera. A disposição da casca em aterros custa à indústria $\mathrm{R} \$ 50,00 /$ tf. Além disso, a geração de energia elétrica a partir dos resíduos de casca de arroz já foi estudada em pesquisa desenvolvida para a ANEEL/MCT/PNUD nos anos de 1999 e 2000, o que demonstra que o interesse das empresas brasileiras já está consagrado.

A aplicação da CCA em compósitos à base de cimento tem como maior vantagem econômica a redução da utilização do cimento. O clínquer é a matéria-prima do cimento que mais necessita de energia $\left(1450^{\circ} \mathrm{C}\right)$. Com a substituição de parte do cimento por cinza da casca de arroz, a economia se daria pela troca de um produto industrializado de custo relativamente alto por um "lixo industrial", sem valor comercial e poluente.

As indústrias de beneficiamento de arroz poderiam se poupar de multas aplicadas por órgãos ambientais e possíveis indenizações por problemas de saúde causados pela má disposição do resíduo se este fosse utilizado como adição e ainda gerando renda suplementar para as mesmas.

Algumas empresas estrangeiras já demonstraram interesse na comercialização da cinza da casca de arroz, o que demonstra o grande potencial econômico do material. 


\section{MÉTODOS E MATERIAIS}

Com o objetivo de se obter parâmetros que permitissem descrever o comportamento das cinzas de casca de arroz como adição cimentícia, inicialmente se fez necessário um estudo dos materiais a serem utilizados nesta pesquisa e da qualidade das misturas de cimento Portland e CCA do ponto de vista da durabilidade. Na seqüência, aplicou-se a cinza da casca de arroz a um produto, um concreto de alto desempenho, e com isto, obtiveram-se parâmetros para a comparação com outras adições. Foi então projetado um traço para o concreto, que teve a fração de CCA que obteve o melhor desempenho no estudo com pastas e argamassas e, posteriormente, realizaram-se ensaios de resistência à compressão. Com a mesma fração de CCA que foi executado o concreto, foram preparadas amostras, as quais foram submetidas a ensaios microscópicos.
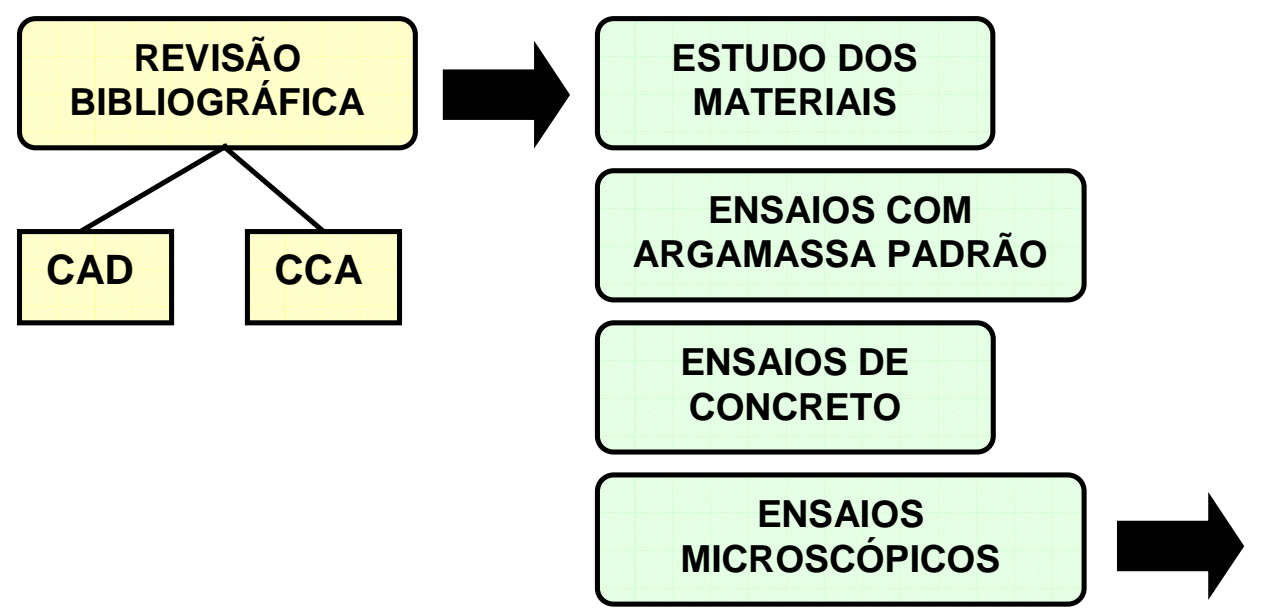

ANÁLISE DE

Figura 47: Esquema do método de trabalho

Anteriormente a fase de ensaios, porém, para se conhecer os resultados dos estudos realizados sobre os assuntos relevantes para a pesquisa, foi desenvolvida uma revisão bibliográfica dos trabalhos publicados até a presente data. De início, foi 
feita uma abordagem sobre "concreto de alto desempenho", que é o produto que se objetiva analisar, e os materiais que o compõem. Em seguida, pretende-se apresentar o material "cinza da casca de arroz" e suas particularidades.

\subsection{MATERIAIS UTILIZADOS}

Todos os ensaios dos materiais realizados nesta pesquisa são baseados em normas nacionais ou internacionais, informações obtidas através de literatura específica e/ou dados comerciais.

Os materiais selecionados para fazerem parte das misturas estão apresentados a seguir.

\subsubsection{Cimento Portland ARI PLUS}

O cimento Portland escolhido para compor todas as misturas executadas neste trabalho é o CPV-ARI PLUS, Cimento Portland de Alta Resistência Inicial, fabricado pela Holcim do Brasil S.A. Este é um cimento de alta resistência inicial, que tem alta reatividade em baixas idades em função do grau de moagem a que é submetido. O clínquer é o mesmo utilizado para a fabricação de um cimento convencional, mas permanece no moinho por um tempo mais prolongado. Por causa da sua finura e por não conter adições pozolânicas, produz alto calor de hidratação, não sendo indicado pra peças muito volumosas. Este cimento atende a NBR 5733 (Cimento Portland de Alta Resistência Inicial).

O CPV-ARI PLUS é um cimento mais puro, já que não contém adições de escória ou pozolanas. Esta foi a razão deste cimento ser escolhido para compor o "novo 
cimento" proposto nesta pesquisa. A presença de outras adições além da cinza da casca de arroz geraria variáveis indesejáveis, que poderiam comprometer a análise dos resultados.

As resistências à compressão nas várias idades do cimento CPV-ARI PLUS fornecidas pelo fabricante estão na Tabela 13 e seguem os procedimentos da NBR 7215:1991.

Tabela 13: Resistência à compressão do CPV-ARI PLUS Fonte: Cimentos Holcim S.A.

\begin{tabular}{cc}
\hline IDADE & RESISTÉNCIA A COMPRESSÃO \\
\hline 1 DIA & $26 \mathrm{MPa}$ \\
3 DIAS & $41 \mathrm{MPa}$ \\
7 DIAS & $46 \mathrm{MPa}$ \\
\hline 28 DIAS & $53 \mathrm{MPa}$ \\
\hline
\end{tabular}

Os tempos de início e fim de pega, determinados de acordo com a NBR 11581:1991, e os demais parâmetros físicos-mecânicos e químicos do cimento estão apresentados nas Tabelas 14 e 15, sucessivamente.

Tabela 14: Propriedades físicas e mecânicas do CPV-ARI PLUS Fonte: Holcim Brasil S.A.

\begin{tabular}{|c|c|c|c|}
\hline ENSAIO & $\begin{array}{c}\text { MÉTODOS DE } \\
\text { ENSAIO }\end{array}$ & RESULTADOS & $\begin{array}{l}\text { LIMITES DA } \\
\text { NBR } 5733 / 91 \\
\end{array}$ \\
\hline FINURA - RESÍDUO NA PENEIRA DE 75 $\mu \mathrm{M}(\%)$ & NBR 11579/91 & 0,1 & $\leq 6,0 \%$ \\
\hline Massa específica $\left(\mathrm{g} / \mathrm{cm}^{3}\right)$ & NBR NM 23/01 & 3,10 & $\star * * *$ \\
\hline Area específica $\left(\mathrm{cm}^{2} / \mathrm{g}\right)$ & NBR NM 76/98 & 4920 & $\geq 300 \mathrm{~m}^{2} / \mathrm{kg}$ \\
\hline Agua da pasta de consistência normal (\%) & NBR NM 43/03 & 28,8 & 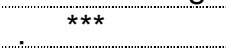 \\
\hline Início de pega (h:min) & NBR NM 65/03 & $2: 50$ & $\geq 1 \mathrm{~h}$ \\
\hline Fim de pega (h:min) & NBR NM 65/03 & $3: 45$ & $\leq 10 \mathrm{~h}$ \\
\hline $\begin{array}{l}\text { Expansibilidade de Le Chatelier - a quente } \\
(\mathrm{mm})\end{array}$ & NBR 11582/91 & 0,0 & $\leq 5 \mathrm{~mm}$ \\
\hline
\end{tabular}

Tabela 15: Propriedades químicas do CPV-ARI PLUS Fonte: Holcim Brasil S.A.

\begin{tabular}{lccc}
\multicolumn{1}{c}{ ENSAIOS } & NORMAS & RESULTADOS & $\begin{array}{c}\text { LIMITES DA } \\
\text { NBR 5733/91 }\end{array}$ \\
\hline PERDA AO FOGO - PF & NBR NM 18/04 & $\mathbf{1 , 3 2}$ & $\leq 4,5 \%$ \\
\hline Óxido de magnésio - MgO & NBR 14656/01 & $\mathbf{0 , 7 1}$ & $\leq 6,5 \%$ \\
Anidrido sulfúrico - $\mathbf{S O}_{3}$ & NBR NM 16/04 & $\mathbf{2 , 8 1}$ & $\leq 4,5 \%$ \\
Anidrido carbônico - CO & NBR NM 20/04 & $\mathbf{0 , 2 7}$ & $\leq 3,0 \%$ \\
\hline Resíduo Insolúvel - RI & NBR NM 15/04 & $\mathbf{0 , 3 0 0}$ & $\leq 1,0 \%$ \\
\hline
\end{tabular}


As exigências físicas e químicas, obrigatórias e facultativas, atendem as especificações da NBR 5733:1991 (Cimento Portland de alta resistência inicial).

A massa específica do cimento CPV-ARI PLUS encontrada a partir do ensaio estabelecido pela NBR 6474:1984 é de $3,02 \mathrm{~g} / \mathrm{cm}^{3}$.

\subsubsection{Cinza da Casca de Arroz}

A cinza da casca de arroz é resíduo da indústria de beneficiamento de arroz da empresa "Urbano Agroindustrial" com sedes nos estados do Rio Grande do Sul e Santa Catarina. A empresa utiliza o dejeto agrícola casca de arroz na produção de energia elétrica. Na unidade em Jaraguá do Sul (SC) e na de São Gabriel (RS), a empresa dispõe de pequenas centrais termoelétricas (PCT) de cogeração de energia, sendo que a primeira gera $3 \mathrm{MW}$ e consome cerca de $4,5 \mathrm{t} / \mathrm{h}$ de casca de arroz. Ainda cerca de $15 \mathrm{t} / \mathrm{h}$ da casca de arroz é aproveitada no processo de parboilização. Deste processo de combustão gera-se a cinza da casca de arroz, que é o material empregado nesta pesquisa. Dentro deste processo, a cinza sofre queima à temperatura de aproximadamente $1000^{\circ} \mathrm{C}$. A temperatura pode ser considerada controlada porque a variação é pequena. A Figura 48 mostra uma imagem de dentro do forno. Depois da queima, a cinza é separada num filtro eletrostático e, então, empacotada em embalagens plásticas para ser armazenada (Figura 49).

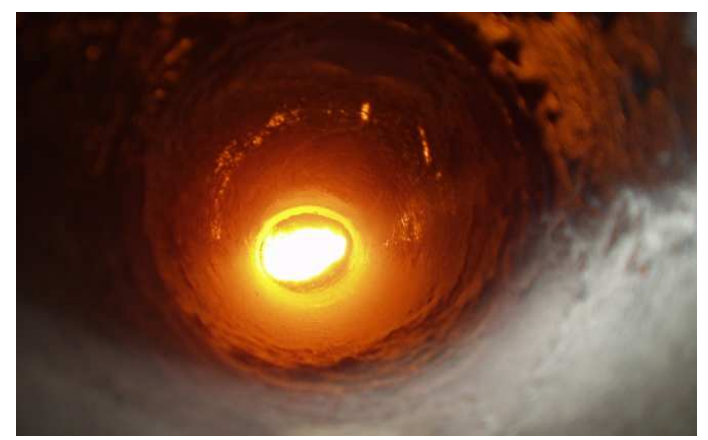

Figura 48: Imagem do interior do forno. 

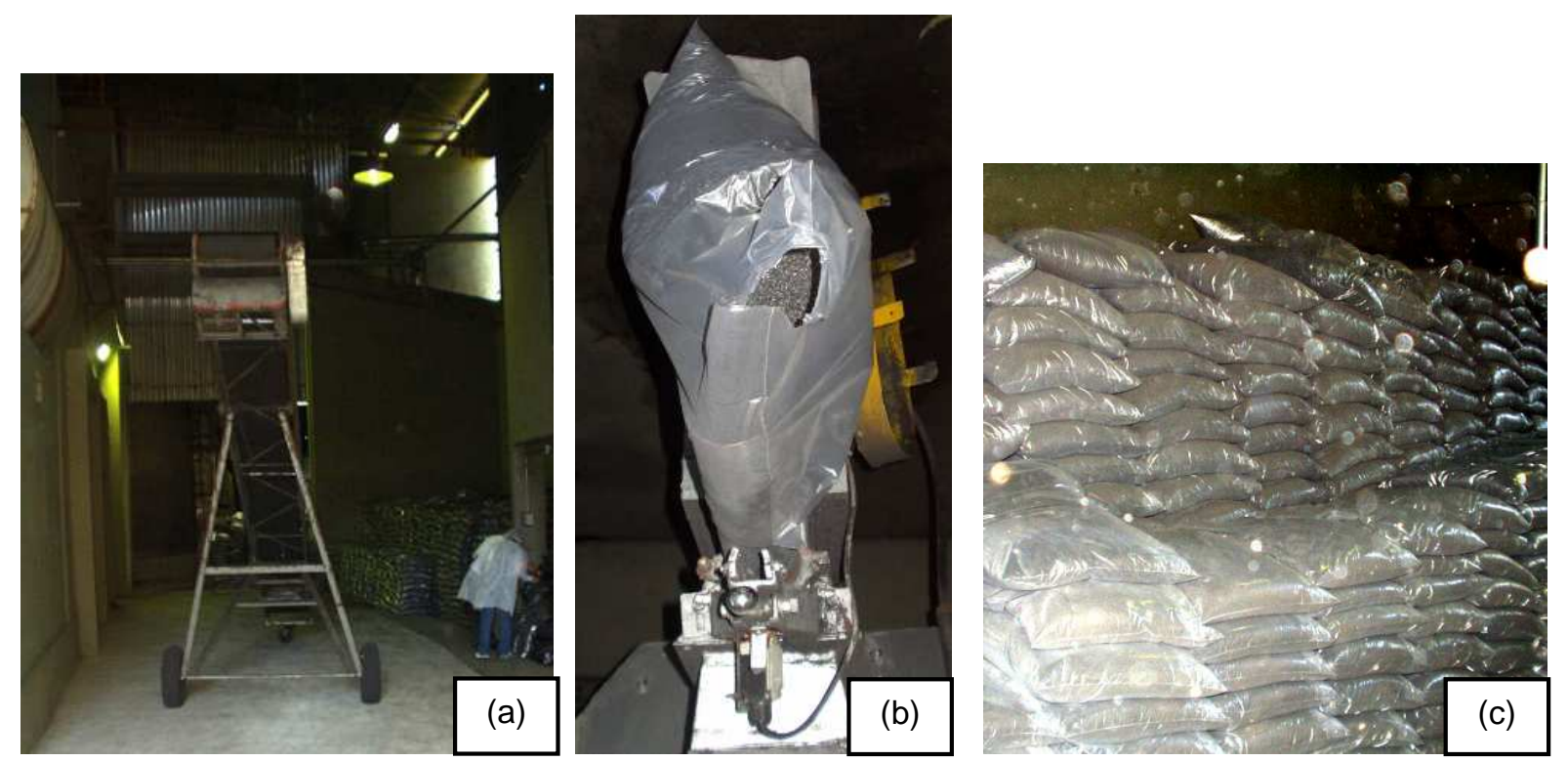

Figura 49: a) Empacotadora; b) Embalagem plástica; c) Armazenagem.

A cinza ao natural é muito grossa para ser utilizada em aglomerantes (Figura 50) apresentando apenas $26,45 \%$ de material passando na peneira ํㅡㄴ $(75 \mu \mathrm{m})$ e $16,08 \%$ passando na peneira ํ325 $(45 \mu \mathrm{m})$ realizados de acordo com a NBR 11579:1991. Por isso, a CCA passou por um processo de moagem industrial até que se torne muito fina. A CCA resultante desta moagem é o material utilizado como base para este estudo.

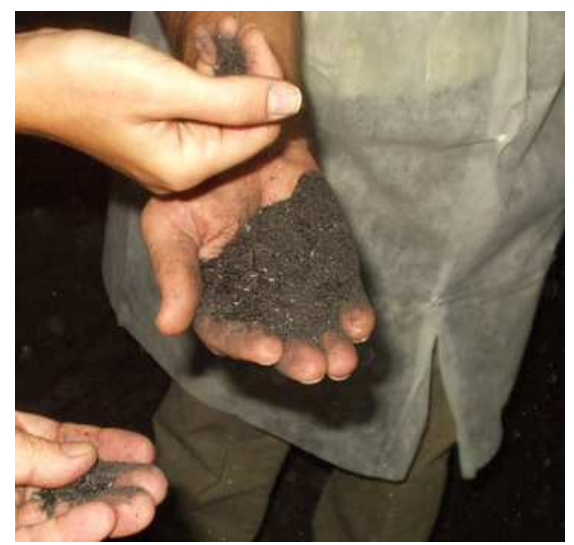

Figura 50: CCA ao natural antes do processo de moagem. 
As principais características da cinza da casca de arroz de interesse são às referentes a sua composição química, massa específica, finura, área específica e, principalmente, a sua pozolanicidade, ou seja, a sua capacidade de reagir com o hidróxido de cálcio.

Realizaram-se ensaios com o objetivo de caracterizar o material e demonstrar que a CCA tem características adequadas e competitivas como opção de adição do CAD para a indústria concreteira e para a comunidade em geral. Por esta razão, estes ensaios foram chamados de ensaios de qualidade.

Sua composição química foi realizada por fluorescência de raios $X$ no CCDM - UFSCar/ UNESP.

A massa específica da cinza de casca de arroz é de $2,05 \mathrm{~g} / \mathrm{cm}^{3}$ e foi obtida a partir do ensaio estabelecido pela NBR 6474:1984.

Em relação à finura da $\mathrm{CCA}, \mathrm{o}$ material foi submetido ao ensaio estabelecido pela NBR 11579:1991 (Cimento Portland: Determinação da finura por meio da peneira $75 \mu \mathrm{m}$ ( $\mathrm{n}^{\circ}$ 200)) pelo procedimento manual. Utilizou-se este mesmo procedimento para o peneiramento com as peneiras no 325 e no 400 (37 $\mu \mathrm{m})$. O material retido nas peneiras $\mathrm{n}^{\circ} 200$ e $\mathrm{n}^{\circ} \mathbf{3 2 5}$ foi insignificante.

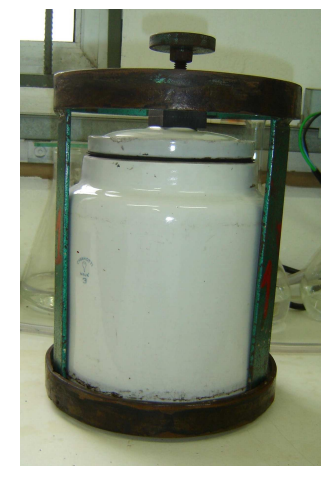

(a)

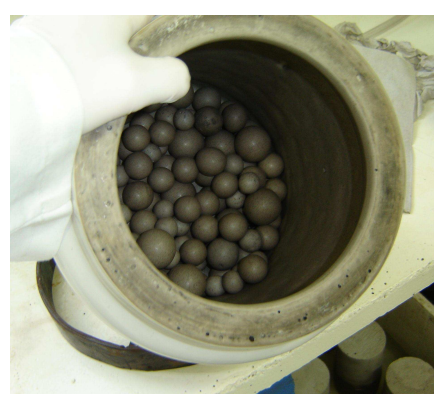

(b)

Figura 51: Moinho de bola. 
A cinza da casca de arroz foi submetida a uma moagem em moinho de bolas por $1 / 2,1,1 \frac{1}{2}$ e 2 horas depois de uma secagem prévia de $24 \mathrm{~h}$ em estufa a $60^{\circ} \mathrm{C}$. O moinho de bolas utilizado é de material cerâmico com bolas do mesmo material com $22 \mathrm{~cm}$ de altura e diâmetro interno igual a $17 \mathrm{~cm}$, conforme Figura 51 . Em seguida o material foi submetido ao ensaio de finura na peneira no $400(37 \mu \mathrm{m})$. A Figura 52 mostra os resultados obtidos.

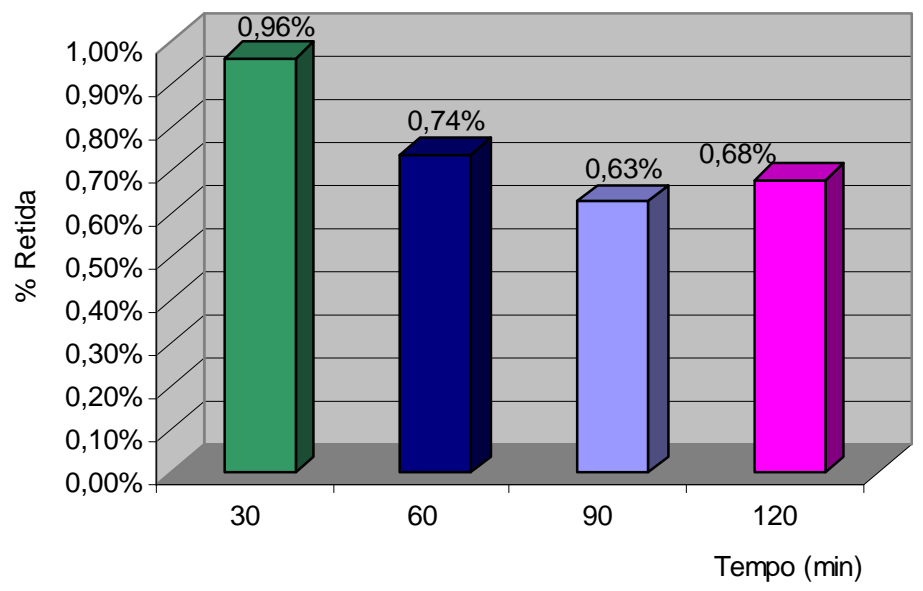

Figura 52: Porcentagem de CCA retida na $\# 400$ x tempo de moagem.

Segundo este estudo preliminar sobre a finura da cinza de casca de arroz, pode-se notar que, mesmo na peneira ํㅜ 400, a com abertura da malha mais fina, muito pouco material ficou retido. Como pode ser notado, apenas as amostras que foram moídas durante 1 e 11/2 hora obtiveram uma redução significativa de granulometria. A moagem por 1 hora é a mais compensadora se for considerada a energia gasta com a moagem e, conseqüentemente, os custos. Concluiu-se com isto que todas as misturas com adição de CCA seriam estudadas com a cinza ao natural, ou seja, sem passarem por mais um processo de moagem além do industrial, e moída por um período de uma hora. 
Fez-se necessário um estudo de granulometria a laser do material para uma determinação mais precisa. Este ensaio foi realizado gentilmente no laboratório de análise da Faber-Castell utilizando como dispersante álcool isopropílico.

A área específica é uma importante característica dos materiais cimentícios porque está diretamente correlacionada à finura, que por sua vez, influi no grau de atividade do material. É influenciada pela distribuição de partículas, forma e rugosidade superficial das mesmas, bem como a distribuição dos poros existentes.

Dois métodos consagrados de medição de área superficial específica são usualmente empregados para materiais cimentícios: Método de Blaine e o Método BET por adsorção de nitrogênio. O primeiro mede a permeabilidade do meio (no caso, das partículas) sendo a área superficial calculada em função do tempo necessário para um volume de ar passar através de uma amostra compacta. No método BET, dados são obtidos pela admissão ou remoção de uma quantidade conhecida de gás adsorvido para dentro ou para fora de um porta-amostra contendo o sólido adsorvente mantido a uma temperatura constante. Com a ocorrência da adsorção, a pressão no portaamostra varia até ser estabelecido um equilíbrio. A quantidade de gás adsorvido na pressão de equilíbrio é a diferença entre a quantidade de gás admitida ou removida e a quantidade requerida para preencher o espaço ao redor do adsorvente, ou seja, o espaço vazio (OLIVEIRA, C. A.S., 2004). Segundo Scrivener (1989), os métodos de permeabilidade fornecem valores muito inferiores aos obtidos por meio de métodos de adsorção porque o ar a que é submetido o sólido não tem acesso a canais bloqueados. Como as partículas de cinza da casca de arroz podem formar grumos, a área específica deve ser determinada pelo método BET por adsorção de nitrogênio. O ensaio foi realizado no laboratório do curso de Engenharia Metalúrgica e de Materiais da USP. 
Por causa dos diferentes comportamentos das várias adições minerais existentes, surgiu a necessidade de qualificar os materiais pozolânicos, sendo introduzido o conceito de atividade pozolânica e o índice de atividade pozolânica (IAP) como um indicador da reatividade e eficácia das pozolanas. Assim, os materiais mais adequados para serem empregados com o cimento Portland ou com a cal, apresentam IAP maiores.

Quanto à pozolanicidade, a cinza da casca de arroz será submetida a três ensaios:

- Determinação da atividade pozolânica com cimento Portland, seguindo as prescrições da NBR 5752:1992;

- Determinação da atividade pozolânica com a cal, seguindo as prescrições da NBR 5751:1992;

- Determinação da pozolanicidade pelo Método Chapelle modificado.

O ensaio de determinação da atividade pozolânica com a cal (hidróxido de cálcio) foi realizado de acordo com a NBR 5751:1992 e consiste em moldar seis corposde-prova de 5 x 10cm com uma argamassa composta por nove partes em massa de areia normal do IPT, uma parte em massa de hidróxido de cálcio puro e mais uma quantidade de material pozolânico que corresponde ao dobro do volume de hidróxido de cálcio utilizado. A massa específica do hidróxido de cálcio PA é de $2,14 \mathrm{~g} / \mathrm{cm}^{3}$, medida de acordo com a NBR 6474:1984. A quantidade de água é a necessária para um índice de consistência de $225 \pm 5 \mathrm{~mm}$ (de acordo com a NBR 7215:1996), neste caso foi de $215 \mathrm{~g}$. Depois de 7 dias de cura, os corpos-de-prova são rompidos à 
compressão. A NBR 12653:1992 (Materiais Pozolânicos) estabelece que o IAP coma cal deve ser maior ou igual a 6MPa.

O ensaio de determinação da atividade pozolânica com o cimento foi realizado de acordo com a NBR 5752:1992 e consiste em moldar duas argamassas, sendo uma de referência (argamassa A) e a outra com substituição de $35 \%$ do volume absoluto do cimento Portland pelo material pozolânico (argamassa B). A atividade pozolânica é dada pela relação entre a resistência à compressão da argamassa $\mathrm{A}$ e a argamassa B. A quantidade de água é a necessária para um índice de consistência de $225 \pm 5 \mathrm{~mm}$ (de acordo com a NBR 7215:1996). São moldados seis corpos-de-prova de $5 \times 10 \mathrm{~cm}$ de cada mistura. Depois de 28 dias de cura, os corpos-de-prova são rompidos à compressão. A NBR 12653:1992 (Materiais Pozolânicos) estabelece que o IAP com o cimento deve ser maior ou igual a $75 \%$.

O ensaio de Chapelle modificado proposto por Raverdi et al., no qual se determina a quantidade de $\mathrm{CaO}$ consumida pela amostra quando submetida a um banho-maria em temperatura de $98^{\circ} \mathrm{C}$ por 16 horas. O material é considerado pozolânico quando apresenta um índice de consumo mínimo de $330 \mathrm{mg}$ de $\mathrm{CaO} / \mathrm{g}$ da amostra.

\subsubsection{Agregado miúdo}

As areias utilizadas neste trabalho nas argamassas são as areias normais estabelecidas pela NBR 7214:1982 (Areia Normal para Ensaio de Cimento). Consiste em um material padronizado quartzoso, extraído do Rio Tietê, no município de São Paulo, em direção à nascente, produzido e fornecido pelo Instituto de Pesquisas Tecnológicas de São Paulo (IPT). O material é submetido a um tratamento com 
hidróxido de sódio por imersão durante 24h para a eliminação de matéria orgânica e em seguida por uma secagem em forno rotativo à temperatura de 60 a $70^{\circ} \mathrm{C}$.

Em relação á granulometria, deve satisfazer às condições e prescrições indicadas nas Tabelas 16 e 17.

Tabela 16: Frações granulométricas e denominação da Areia Normal. Fonte: NBR7214:1982.

\begin{tabular}{|c|c|c|}
\hline $\begin{array}{l}\text { Material retido entre as peneiras } \\
\text { de abertura nominal de: }\end{array}$ & Denominação & $\begin{array}{l}\% \text { em peso da } \\
\text { areia normal }\end{array}$ \\
\hline $2,4 \mathrm{~mm} \mathrm{e} 1,2 \mathrm{~mm}$ & Grossa & $25 \%$ \\
\hline $1,2 \mathrm{~mm}$ e $0,6 \mathrm{~mm}$ & Média grossa & $25 \%$ \\
\hline $0,6 \mathrm{~mm}$ e $0,3 \mathrm{~mm}$ & Média fina & $25 \%$ \\
\hline $0,3 \mathrm{~mm}$ e $0,15 \mathrm{~mm}$ & Fina & $25 \%$ \\
\hline \multicolumn{3}{|c|}{$\begin{array}{l}\text { Tabela 17: Frações granulométricas da Areia Normal. } \\
\text { Fonte: NBR7214:1982. }\end{array}$} \\
\hline \multicolumn{2}{|l|}{ Peneira ABNT } & \multirow{2}{*}{$\begin{array}{l}\text { Porcentagem } \\
\text { etida, acumulada, } \\
\text { em peso. }\end{array}$} \\
\hline $\begin{array}{r}\text { Abertur } \\
(n\end{array}$ & $\begin{array}{l}\text { Abertura nominal } \\
(\mathrm{mm})\end{array}$ & \\
\hline 8 & 2,4 & 0 \\
\hline 10 & 2,0 & $5 \pm 5$ \\
\hline 16 & 1,2 & $25 \pm 5$ \\
\hline 30 & 0,6 & $50 \pm 5$ \\
\hline 50 & 0,3 & $75 \pm 5$ \\
\hline 100 & 0,15 & $97 \pm 3$ \\
\hline
\end{tabular}

A areia utilizada nos concretos tem como origem cavas na região de São Carlos (SP). Alguns parâmetros fundamentais sobre este agregado são apresentados na Tabela 18 abaixo:

Tabela 18: Propriedades do agregado miúdo

\begin{tabular}{lcc}
\hline Massa específica $\left(\mathbf{g} / \mathbf{c m}^{3}\right)$ & NBR 9776:1987 & 2,63 \\
\hline Dimensão máxima característica $(\mathbf{m m})$ & $-\cdots$ & 4,8 \\
\hline Módulo de finura & $-\cdots$ & 2,3 \\
\hline
\end{tabular}

A análise granulométrica, determinada de acordo com a NBR 7217:1987, é apresentada na Tabela 19. A Figura 53 mostra a curva granulométrica da areia 
segundo a classificação da NBR 7211:1983. De acordo com esta norma, a areia é classificada na zona 2 e é do tipo fina.

Tabela 19: Distribuição granulométrica do agregado miúdo

\begin{tabular}{ccc}
\hline PENEIRA (mm) & \% RETIDA & $\begin{array}{c}\text { \% RETIDA } \\
\text { ACUMULADA }\end{array}$ \\
\hline $\mathbf{9 , 5}$ & 0 & 0 \\
$\mathbf{6 , 3}$ & 2 & 2 \\
$\mathbf{4 , 8}$ & 1 & 3 \\
$\mathbf{2 , 4}$ & 4 & 7 \\
$\mathbf{1 , 2}$ & 7 & 14 \\
$\mathbf{0 , 6}$ & 12 & 26 \\
$\mathbf{0 , 3}$ & 54 & 80 \\
$\mathbf{0 , 1 5}$ & 18 & 98 \\
\hline Fundo & 2 & 100 \\
\hline
\end{tabular}

*Peneira intermediária

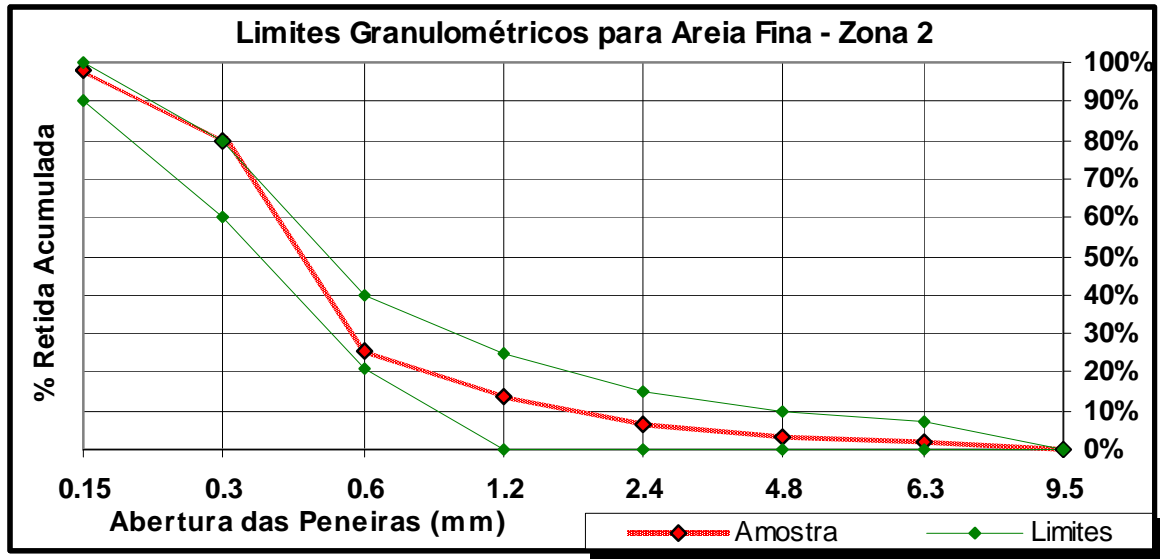

Figura 53: Curva granulométrica da areia.

O desempenho de uma dada areia se deve, principalmente, a sua influência na quantidade de água requerida e ao empacotamento das partículas. Quanto mais fino for o agregado miúdo, maior a quantidade de água necessária para se atingir determinada trabalhabilidade. Em relação ao empacotamento, o teor de vazios tende a diminuir com o aumento do teor de material arredondado, ou seja, é afetado pela forma das partículas da areia.

Um parâmetro sobre a forma dos agregados é o número de angulosidade (NA), cujo conceito se encontra na norma britânica BS 812: Parte 1 (1975). O NA é 
definido subtraindo-se de 67 a porcentagem de volume de sólidos em um recipiente preenchido com agregados segundo um procedimento estabelecido. O número 67 representa a porcentagem de volume sólido do agregado mais arredondado. Quanto maior o número, mais anguloso o agregado. O número de angulosidade geralmente está entre 0 e 11.

$$
N A(\%)=67-\left(\frac{m}{\rho_{\text {AREIA }} \cdot V_{R}} \cdot 100\right)
$$

Sendo:

$$
\begin{aligned}
& m=\text { massa contida no recipiente }(\mathrm{g}) \\
& \rho_{\text {AREIA }}=\text { massa específica da areia }\left(\mathrm{g} / \mathrm{cm}^{3}\right) \\
& V_{R}=\text { volume do recipiente }
\end{aligned}
$$

O número de angulosidade da areia utilizada foi de -1 , representando que o número de vazios do agregado utilizado é menor em $1 \%$ a de um agregado esférico. Esta condição interfere favoravelmente na trabalhabilidade e significa que o agregado possui um empacotamento adequado, dispensando a composição com outro agregado miúdo.

\subsubsection{Agregado graúdo}

A composição granulométrica, isto é, a proporção relativa expressa em forma de porcentagem em que se encontram os grãos de um certo agregado, tem importante influência sobre a qualidade dos concretos, agindo na compacidade e 
resistência. A melhor composição é a que apresenta a menor quantidade de vazios. Para um melhor empacotamento entre as partículas, foram utilizados dois tipos de agregados graúdos: brita $1\left(D_{\operatorname{máx}}=19 \mathrm{~mm}\right)$ e pedrisco $\left(D_{\operatorname{máx}}=6,3 \mathrm{~mm}\right)$.

Alguns parâmetros essenciais sobre este agregado são apresentados na Tabela 20 abaixo:

Tabela 20: Propriedades dos agregados graúdos.

\begin{tabular}{lccc}
\hline \multicolumn{1}{c}{ PROPRIEDADES } & NORMAS & PEDRISCO & BRITA 1 \\
\hline Massa específica $\left(\mathbf{g} / \mathbf{c m}^{3}\right)$ & NBR 9937:1987 & 2,88 & 2,88 \\
\hline Absorção (\%) & NBR 9937:1987 & 0,3 & 0,3 \\
\hline Dimensão máxima característica $(\mathbf{m m})$ & --- & 6,3 & 19,0 \\
\hline Módulo de finura & --- & 4,76 & 6,59 \\
\hline
\end{tabular}

A determinação da proporção adequada de cada tipo de agregado é recomendada pela NBR 7810:1983 (Agregado em estado compactado seco: determinação da massa unitária) e Helene e Terzian (1992). A melhor proporção encontrada e a que foi adotada é de $70 \%$ de brita 1 e $30 \%$ de pedrisco.

As análises granulométricas do pedrisco e brita 1, determinadas de acordo com a NBR 7217:1987, estão apresentadas nas Tabela 21 e 22, respectivamente.

Tabela 21: Distribuição granulométrica do pedrisco.

\begin{tabular}{ccc}
\hline PENEIRA (mm) & \% RETIDA & $\begin{array}{c}\text { \% RETIDA } \\
\text { ACUMULADA }\end{array}$ \\
\hline $\mathbf{6 , 3 ^ { * }}$ & 0 & 0 \\
$\mathbf{4 , 8}$ & 7,3 & 7 \\
$\mathbf{2 , 4}$ & 75,4 & 83 \\
$\mathbf{1 , 2}$ & 11,7 & 94 \\
$\mathbf{0 , 6}$ & 2,1 & 96 \\
$\mathbf{0 , 3}$ & 0,8 & 97 \\
$\mathbf{0 , 1 5}$ & 0,7 & 98 \\
Fundo & 2,1 & 100 \\
\hline
\end{tabular}

*Peneira intermediária 
Tabela 22: Distribuição granulométrica da brita 1.

\begin{tabular}{ccc}
\hline PENEIRA (mm) & \% RETIDA & $\begin{array}{c}\text { \% RETIDA } \\
\text { ACUMULADA }\end{array}$ \\
\hline $\mathbf{1 9}$ & 0 & 0 \\
$\mathbf{1 2 , 5 ^ { * }}$ & 22,4 & 22 \\
$\mathbf{9 , 5}$ & 39,3 & 62 \\
$\mathbf{6 , 3}$ & 32,6 & 94 \\
$\mathbf{4 , 8}$ & 4,8 & 99 \\
$\mathbf{2 , 4}$ & 0,6 & 100 \\
$\mathbf{1 , 2}$ & 0 & 100 \\
$\mathbf{0 , 6}$ & 0 & 100 \\
$\mathbf{0 , 3}$ & 0 & 100 \\
$\mathbf{0 , 1 5}$ & 0 & 100 \\
Fundo & 0 & 100 \\
\hline
\end{tabular}

${ }^{*}$ Peneira intermediária

Da mesma maneira que para os agregados miúdos, a forma dos agregados graúdos poderá interferir na resistência do concreto e ainda criar grandes falhas no concreto. Um dos métodos que pode ser utilizado para avaliar a forma dos agregados consiste em se determinar um coeficiente volumétrico médio de uma amostra obtida a partir do quarteamento de um lote representativo de agregado, até obter-se uma massa de $250 \mathrm{~g}$. Calcula-se o volume dos agregados, por exemplo, pelo deslocamento de um líquido de volume previamente conhecido, obtendo-se então o valor $\mathrm{V}$, que é o volume da amostra. O agregado deverá estar no estado saturado, porém com superfície seca. A seguir, faz-se a medida dos diâmetros "d" de cada partícula, conforme Figura 54, e se calcula o Coeficiente Volumétrico $\left(\mathrm{C}_{\mathrm{v}}\right)$.

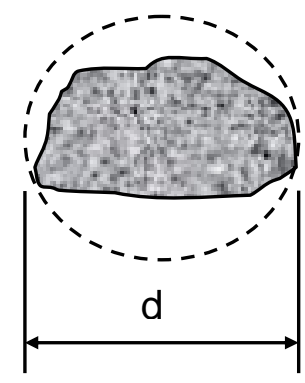

Figura 54: Diâmetro para cálculo do Coeficiente Volumétrico do agregado.

O índice $\mathrm{C}_{v}$ é a razão entre o volume dos agregados e a somatória dos volumes de cada partícula. O coeficiente volumétrico da brita composta é de 0,2 . Esse 
valor de coeficiente volumétrico caracteriza agregados de forma alongada, forma esta que pode levar a uma flexão no agregado. A medida preventiva adotada foi a dopagem com $100 \%$ da cinza de casca de arroz e $20 \%$ da água de amassamento (Figura 55).

Figura 55: Dopagem do agregado graúdo com CCA.

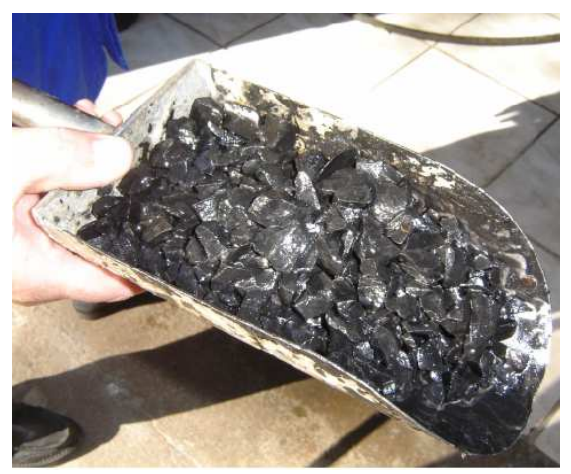

\subsection{ENSAIOS DE QUALIDADE E RESISTÊNCIA DO “NOVO CIMENTO”}

Anteriormente à dosagem do concreto, deverão ser realizados ensaios de qualidade com o "novo cimento" composto pela mistura binária de cimento e 0, 5, 10 e $15 \%$ de adição de cinza da casca do arroz de parte do cimento a fim de se avaliar a sinergia entre esta pozolana e o cimento Portland em pastas e argamassas. São chamados de ensaio de qualidade de um material aqueles para os quais há limitações normativas para classificá-los ou caracterizá-los. Os resultados destes ensaios permitiram a análise e determinação da melhor entre as frações.

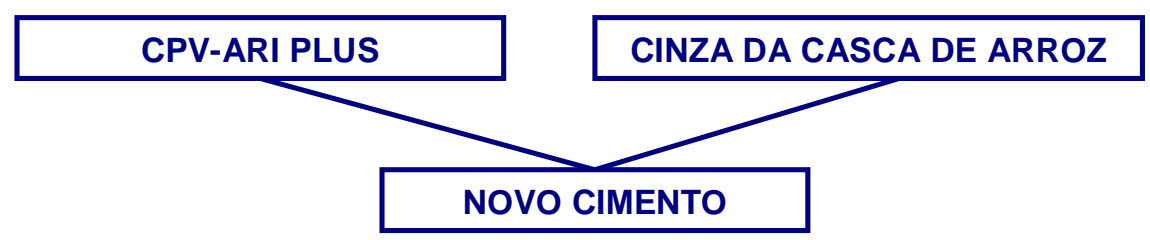

Figura 56: Esquema do novo cimento 
Para realizar a avaliação das misturas, serão executados ensaios seguindo os procedimentos estabelecidos pelas referidas normas, são eles:

- Determinação da resistência à compressão (NBR 7215:1991);

- Determinação da resistência à tração por compressão diametral (NBR 7222:1994);

- Determinação dos tempos de pega (NBR 11581:1991);

\subsubsection{Resistência à compressão}

A resistência à compressão é, em geral, a propriedade mais importante requerida dos compósitos à base de cimento porque está diretamente ligada à estrutura interna do material, fornecendo uma importante estimativa sobre a durabilidade. Além disso, a resistência à compressão é uma propriedade dos materiais exaustivamente estudada, o que permite comparações e correlações com outros trabalhos e materiais e o ensaio para sua determinação é de fácil execução em laboratório.

O ensaio de resistência à compressão é realizado com corpos-de-prova cilíndricos de $5 \times 10 \mathrm{~cm}$ com as amostras de argamassa padrão saturadas com a superfície seca, conforme a NBR 7215:1991. Mehta e Monteira (1994) comentam que corpos-de-prova secos ao ar apresentam resistências de 20 a 25\% maiores do que os corpos-de-prova em condição saturada. Segundo eles, a menor resistência do concreto saturado é provavelmente devido à existência de uma pressão de desligamento na pasta de cimento.

A relação água-aglomerante de norma é 0,48 . Esta relação foi mantida para todas as misturas. 
As idades ensaiadas foram: 24horas, 3, 7, 14, 28, 56 e 91 dias. A norma NBR 7215:1991 não especifica a idade de 14 dias, mas ela foi incluída por se tratar de um cimento composto com adição de material pozolânico e mudanças significativas ocorrem no período entre a primeira e a segunda semana de idade. A cura foi realizada por imersão em água saturada com cal. Os corpos-de-prova são retirados da cura no momento do ensaio.

Foram moldadas 7 misturas diferentes, variando a fração de CCA em substituição em massa de cimento Portland. A cinza da casca de arroz foi utilizada com a finura que veio da indústria e moída por 1 hora em moinho de bolas. As misturas confeccionadas estão na Tabela 23. Para cada mistura foram ensaiados 4 corpos-deprova.

Tabela 23: Argamassas padrão confeccionadas com CCA.

\begin{tabular}{ll}
\hline REF & Argamassa de referência com $0 \%$ de CCA. \\
$5 \%$ SM & Argamassa com $5 \%$ de CCA. \\
$10 \%$ SM & Argamassa com $10 \%$ de CCA. \\
$15 \%$ SM & Argamassa com $15 \%$ de CCA. \\
$5 \% \mathrm{M}$ hr & Argamassa com $5 \%$ de CCA moída por 1 hora. \\
$10 \% M 1 \mathrm{hr}$ & Argamassa com $10 \%$ de CCA moída por 1 hora. \\
$15 \% \mathrm{M}$ hr & Argamassa com $15 \%$ de CCA moída por 1 hora. \\
\hline
\end{tabular}

O traço da argamassa é de 1:3. As quantidades de materiais, segundo a NBR 7215:1991, está na Tabela 24.

Tabela 24: Quantidades de materiais para argamassa padrão.

\begin{tabular}{lc}
\hline \multicolumn{1}{c}{ MATERIAL } & MASSA PARA MISTURA (g) \\
\hline Novo cimento = (CPV-ARI PLUS + \%CCA) & $624 \pm 0,4$ \\
\hline Água & $300 \pm 0,2$ \\
\hline Areia normal fração grossa & $468 \pm 0,3$ \\
\hline Areia normal fração média grossa & $468 \pm 0,3$ \\
\hline Areia normal fração média fina & $468 \pm 0,3$ \\
\hline Areia normal fração fina & $468 \pm 0,3$ \\
\hline
\end{tabular}

Para permitir conclusões mais confiáveis, os resultados foram submetidos a um estudo estatístico por análise de variância. A partir desta análise, obtém-se uma 
razão "R" que segue uma distribuição do tipo $\mathrm{F}$. Se a hipótese nula, que neste caso é representada pela condição "médias são iguais", for comprovada verdadeira , a razão R deve ficar em torno do valor unitário com grande probabilidade. Se for falsa, a razão tenderá a crescer e quanto maior for esta razão, maior a probabilidade de as médias entre os tratamentos experimentais serem diferentes (NUNES, N. L., 1998).

Com a análise de variância é possível identificar se as variáveis "teor de CCA" e "moagem" influenciam significativamente na resistência à compressão das argamassas padrão e se as médias calculadas são realmente diferentes do ponto de vista estatístico. Estas conclusões são possíveis analisando-se os valores da razão $R$ da variável e o valor crítico de $\mathrm{R}$ para um determinado intervalo do confiança estatística $\left(F_{\text {crit }}\right)$. Se o valor $R$ for maior que $F_{\text {crit, }}$ existe diferença entre as médias na resistência à compressão.

Outra análise possível se refere à razão entre o $\mathrm{R}$ da variável e o seu $\mathrm{F}_{\text {crit. }}$ Quanto maior o valor da razão entre $R$ e $F_{\text {crit, }}$ mais significativa é a influência que a variável em questão exerce em determinada propriedade. Caso o valor $\mathrm{R}$ for inferior ao

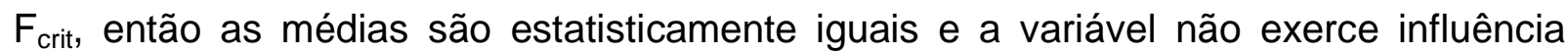
significativa na resistência à compressão. No presente trabalho serão analisadas as variáveis "teor de CCA" e "moagem" em relação à propriedade resistência à compressão axial. O nível de significância ou de confiança adotado foi de 95\%.

\subsubsection{Resistência à tração por compressão diametral}

No ensaio de tração por compressão diametral, os corpos-de-prova cilíndricos de argamassa são submetidos à cargas de compressão ao longo de duas linhas axiais, as quais são diametralmente opostas, conforme Figura 57. A tensão de 
compressão produz uma tensão transversal que é uniforme ao longo do diâmetro vertical. A resistência à tração determinada pelo ensaio de compressão diametral é calculada pela fórmula:

$$
f_{t, D}=\frac{2 \cdot F}{\pi \cdot L \cdot d}
$$

Sendo $f_{t, D}$ a resistência à tração por compressão diametral em $\mathrm{MPa}, F \mathrm{a}$ carga máxima de ruptura $(\mathrm{kN}), L$ a altura do corpo-de-prova $(\mathrm{mm})$ e $d$ o diâmetro do corpo-de-prova (mm).

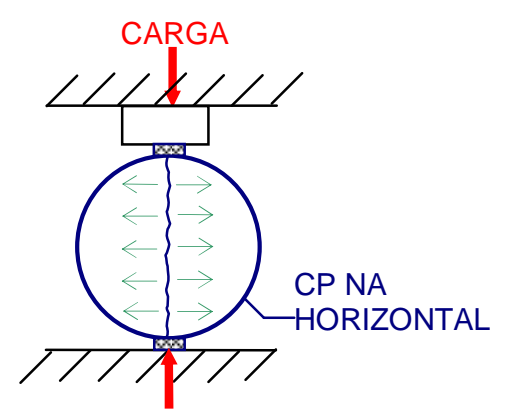

Figura 57: Ensaio de compressão diametral para determinar a resistência à tração indireta.

Este não é um ensaio de qualidade, pois não existem limitações de norma sobre a resistência à tração por compressão diametral, mas é importante para uma avaliação do comportamento de argamassas com CCA em relação a este tipo de esforço.

O ensaio foi realizado com as misturas da Tabela 24 em corpos-de-prova cilíndricos de 5 x 10cm e ensaiados nas idades de 24horas, 3, 7, 14, 28, 56 e 91 dias. Foram rompidos 2 corpos-de-prova por idade de cada mistura. 


\subsubsection{Tempos de pega}

O ensaio de determinação dos tempos de pega do cimento é importante, principalmente, no controle de qualidade do cimento, pois permite uma verificação se as adições de gesso estão nos teores preestabelecidos, uma vez que é este que controla o fenômeno de pega no cimento. Outra função do ensaio diz respeito ao concreto, que deve ser lançado no estado plástico. Dispondo-se dos resultados do início de pega do cimento, pode-se associá-lo ao concreto, estimando o tempo máximo possível para o lançamento.

A NBR 11581:1991 define como tempo de início de pega o intervalo decorrido entre $\mathrm{o}$ instante em que se lançou a água de amassamento à pasta e o instante em que se constatou o início de pega, ou seja, quando a agulha de Vicat estacionar a $1 \mathrm{~mm}$ da placa de vidro. Tempo de fim de pega é o intervalo decorrido entre o instante em que se lançou a água de amassamento à pasta e o instante em que se constatou o fim de pega, ou seja, quando a agulha de Vicat estacionar a $38 \mathrm{~mm}$ da placa de vidro ou mais. Para os ensaios foi empregado aparelho de Vicat automático (Figura 58a).

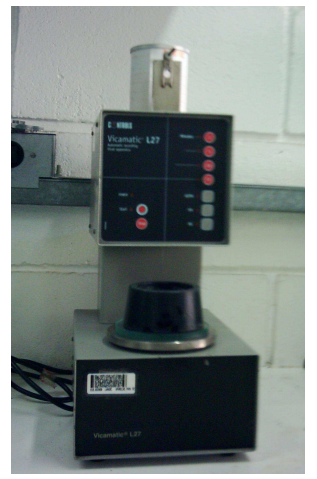

(a)

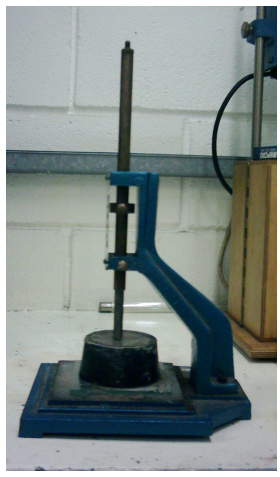

(b)
Figura 58: Aparelho de Vicat.

(a) automático com agulha de Vicat;

(b) manual com sonda de Tetmajer. 
Para determinação dos tempos de pega, a NBR 11581:1991 estabelece que a pasta a ser utilizada deve ser composta de $500 \mathrm{~g}$ de cimento e água necessária para a consistência normal, que é encontrada seguindo a NBR 11580:1991. Para este ensaio também é utilizado o aparelho de Vicat, mas com penetração da extremidade da haste denominada sonda de Tetmajer (Figura 58b). Os resultados do estudo da quantidade necessária de água para a consistência normal estão demonstrados na Figura 59. Nota-se que o consumo de água necessário para se obter a mesma consistência cresce com a quantidade de adição de cinza da casca de arroz, o que confirma as informações obtidas na teoria.

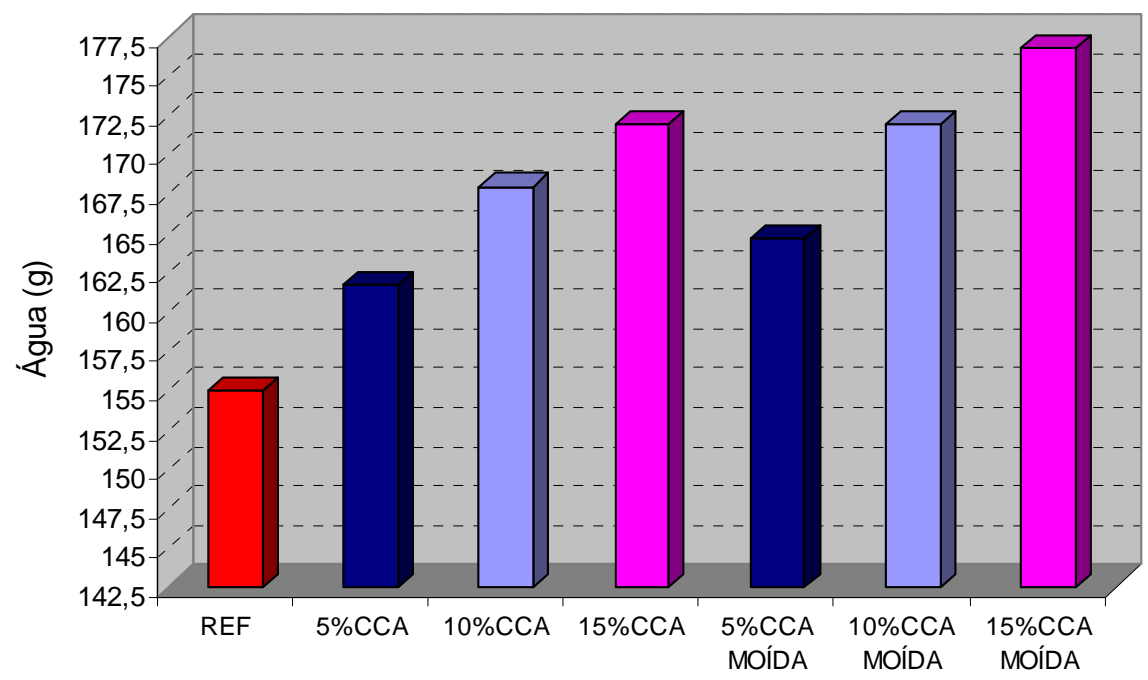

Figura 59: Consumo de água para pasta de consistência normal.

\subsection{DOSAGEM DOS CONCRETOS}

A dosagem de concreto é o processo pelo qual é obtida a melhor proporção entre cimento, agregados, água, aditivos e adições para produzir um concreto que atenda certas especificações prévias, como por exemplo, a trabalhabilidade do concreto fresco e a resistência mecânica do concreto endurecido, a um custo mínimo. 
Para os concretos, o procedimento para dosagens das misturas foi baseado no método recomendado por Helene e Terzian (1992) e Liborio (2004). As propriedades fundamentais de todos os materiais envolvidos devem ser determinadas previamente. Foram executadas misturas com e sem adição de CCA com traços 1:m com $m$ assumindo os seguintes valores: $3,5-5,0-6,5$. A Tabela 25 traz as misturas realizadas.

Foi utilizada uma proporção de $15 \%$ de cinza da casca de arroz em substituição em massa de cimento porque, nos ensaios com a argamassa padrão, foi o valor que obteve os melhores resultados.

Tabela 25: Concretos a serem realizados

\begin{tabular}{lcl}
\hline CCA-1:3,5 & $1: 3,5$ & Concreto com 15\% de cinza da casca de arroz com traço 1:3,5 \\
\hline CCA-1:5 & $1: 5$ & Concreto com 15\% de cinza da casca de arroz com traço 1:5 \\
\hline CCA-1:6,5 & $1: 6,5$ & Concreto com 15\% de cinza da casca de arroz com traço 1:6,5 \\
\hline PLUS-1:3,5 & $1: 3,5$ & Concreto sem adição de cinza de casca de arroz com traço 1:3,5 \\
\hline PLUS-1:5 & $1: 5$ & Concreto sem adição de cinza de casca de arroz com traço 1:5 \\
\hline PLUS-1:6,5 & $1: 6,5$ & Concreto sem adição de cinza de casca de arroz com traço 1:6,5 \\
\hline
\end{tabular}

Ressalta-se que as adições foram introduzidas no concreto por substituição em peso do cimento. Esta forma de substituição é a utilizada nos cimentos compostos estabelecidos pela NBR 11578:1991. Desta maneira, o volume da mistura composta de cimento Portland e CCA será maior que o de uma mistura de mesma massa de cimento porque a massa específica da cinza da casca de arroz é menor que a do cimento empregado.

A relação água-aglomerante foi, a princípio, fixada em 0,45 para todos os concretos. Esta relação foi escolhida tendo em vista a NBR 6118:2003 que estabelece este valor como sendo o limite máximo para a classe de agressividade IV, conforme Tabela 26. Esta classe de agressividade é a mais rigorosa, de acordo com a norma e, conseqüentemente, esta relação água-aglomerante também é. Porém, por causa de 
ajustes no traço, os concretos 1:6,5, foram produzidos com relação água-aglomerante de 0,465 e os demais concretos com relação igual a 0,44.

Tabela 26: Correspondência entre classe de agressividade e qualidade do concreto. Fonte: Tabela 7.1 da NBR 6118:2003.

\begin{tabular}{|c|c|c|c|c|c|}
\hline \multirow{2}{*}{ Concreto } & \multirow{2}{*}{ Tipo } & \multicolumn{4}{|c|}{ Classe de agressividade } \\
\hline & & I & II & III & IV \\
\hline \multirow{2}{*}{$\begin{array}{c}\text { Relação água/cimento } \\
\text { em massa }\end{array}$} & CA & $\leq 0,65$ & $\leq 0,60$ & $\leq 0,55$ & $\leq 0,45$ \\
\hline & CP & $\leq 0,60$ & $\leq 0,55$ & $\leq 0,50$ & $\leq 0,45$ \\
\hline \multirow{2}{*}{$\begin{array}{c}\text { Classe de concreto (NBR } \\
\text { 8953) }\end{array}$} & CA & $\geq \mathrm{C} 20$ & $\geq \mathrm{C} 25$ & $\geq$ C30 & $\geq \mathrm{C40}$ \\
\hline & CP & $\geq \mathrm{C} 25$ & $\geq \mathrm{C} 30$ & $\geq$ C35 & $\geq \mathrm{C} 40$ \\
\hline \multicolumn{6}{|c|}{$\begin{array}{l}\text { NOTAS } \\
1 \text { O concreto empregado na execução das estruturas deve cumprir com os requisitos } \\
\text { estabelecidos na NBR } 12655 \text {. } \\
2 \text { CA corresponde a componentes e elementos estruturais de concreto armado. } \\
3 \text { CP corresponde a componentes e elementos estruturais de concreto protendido. }\end{array}$} \\
\hline
\end{tabular}

Segundo o ACl 211.4R-93, a trabalhabilidade é a propriedade do concreto fresco que determina a facilidade com que pode ser misturado, moldado, adensado e acabado sem segregação. A NBR 7223:1992 estabelece um método de determinação da consistência a partir da medida do abatimento do concreto num tronco de cone metálico de $30 \mathrm{~cm}$ de altura. Quanto maior o abatimento, mais fluido é o concreto.

O abatimento do concreto fresco foi fixado em $130 \pm 20 \mathrm{~mm}$. O abatimento entre 100 e $150 \mathrm{~mm}$ é considerado fluido, tendo uma tolerância de $\pm 20 \mathrm{~mm}$. Este valor para o abatimento foi escolhido porque é suficientemente fluido para ser bombeado ${ }^{13} \mathrm{e}$ não há necessidade de valores excessivos de superplastificante na mistura, o que a tornaria mais cara.

O teor do aditivo superplastificante adotado poderá variar de acordo com a mistura. A dosagem ótima de superplastificante e a compatibilidade cimento-aditivo foram determinadas pelo ensaio do mini abatimento de tronco de cone desenvolvido por Kantro (1980). O procedimento consiste em fazer um ensaio de abatimento com pasta,

\footnotetext{
${ }^{13}$ Segundo informações de concreteiras da região de São Carlos (SP), o abatimento mínimo de concretos bombeáveis é $80 \pm 20 \mathrm{~mm}$.
} 
utilizando um tronco de cone de dimensões reduzidas e uma placa de vidro, e obter a área de espalhamento da pasta. Este ensaio permite avaliar o aditivo quanto ao seu poder fluidificante e alterações de fluidez da pasta com o tempo servindo para uma préqualificação do superplastificante.

Foram testados 3 superplastificantes em pastas com 15\% de adição de CCA. São eles:

- Adva Cast da Grace Construction Products;

- Glenium 51 da Degussa Construction Chemicals;

- Sikament 300 da Sika Products.

Os resultados obtidos estão expostos no gráfico da Figura 60.

De acordo com a Figura 60, conclui-se que o Sikament 300 não obteve resultado satisfatório. O Glenium 51 teve seu grau de saturação atingido com adição de 0,65\% e área de espalhamento de $304 \mathrm{~cm}^{2}$. Já o Adva Cast apresentou um comportamento excelente, com área de espalhamento de $232 \mathrm{~cm}^{2}$ com $0,4 \%$ de aditivo e atingindo o ponto de saturação com $1,4 \%$ e área de $425 \mathrm{~cm}^{2}$. Como conseqüência destes estudos, adotou-se o superplastificante Adva Cast como aditivo nos concretos executados.

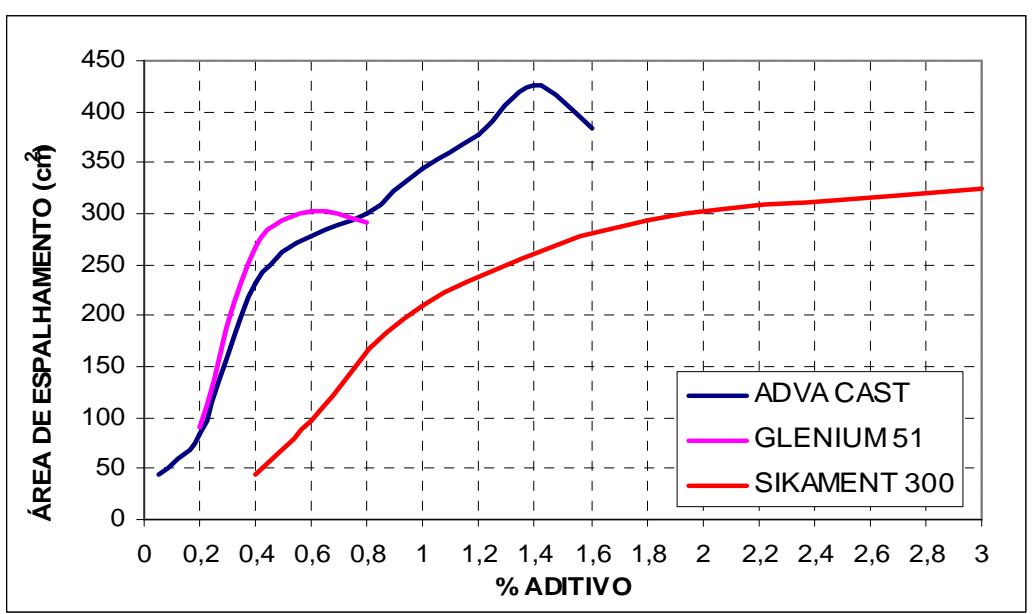

Figura 60: Curvas de saturação dos aditivos testados. 
Helene e Terzian (1992) recomendam a determinação do teor de argamassa ótimo previamente. São utilizados testes visuais para a determinação. Um deles é alisar com a colher de pedreiro a mistura que deve apresentar uma superfície lisa (Figura 61a). Outro teste está relacionado à coesão e consiste em pegar uma certa quantidade de concreto com uma colher de pedreiro. A mistura estará adequada se permanecer coesa na colher, conforme Figura 61b. Foi realizado outro teste para comprovar a coesão do concreto. Fincou-se a haste metálica na mistura e o furo permaneceu aberto, comprovando a qualidade do concreto quanto à coesão (Figura 61c). O valor encontrado e empregado para o teor de argamassa foi de $53 \%$.
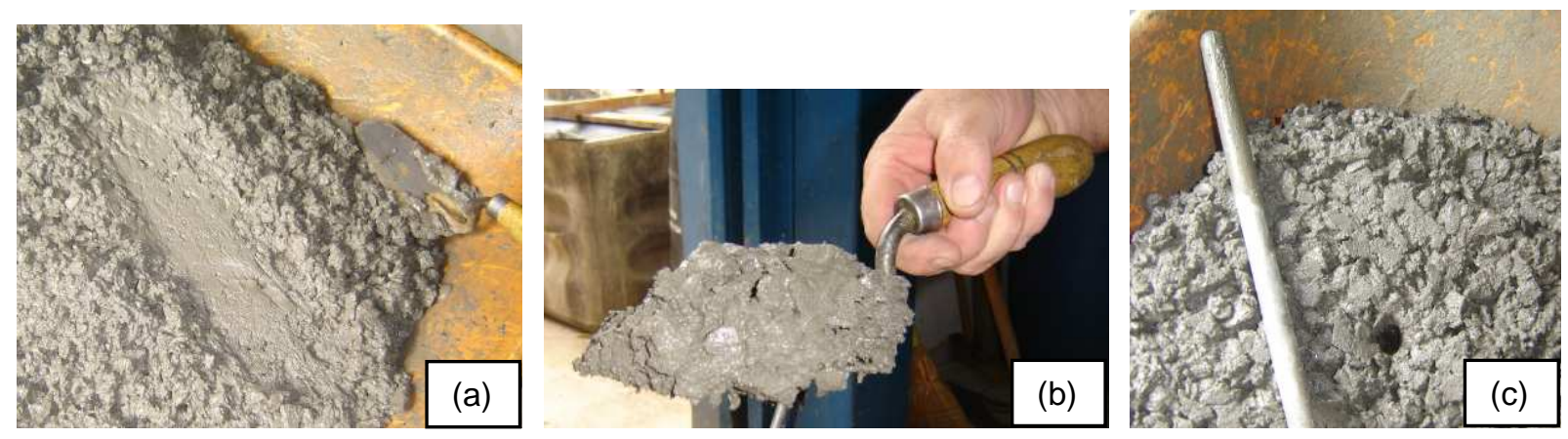

Figura 61: Testes para a determinação do teor de argamassa ótimo.

(a) Acabamento liso; (b) Teste de coesão com a colher; (c) Teste de coesão com o furo.

A partir dos dados mencionados, calculou-se o traço dos concretos a serem executados. As quantidades de materiais por $\mathrm{m}^{3}$ estão expostas na Tabela 27.

Tabela 27: Consumo de materiais para $1 \mathrm{~m}^{3}$ de concreto.

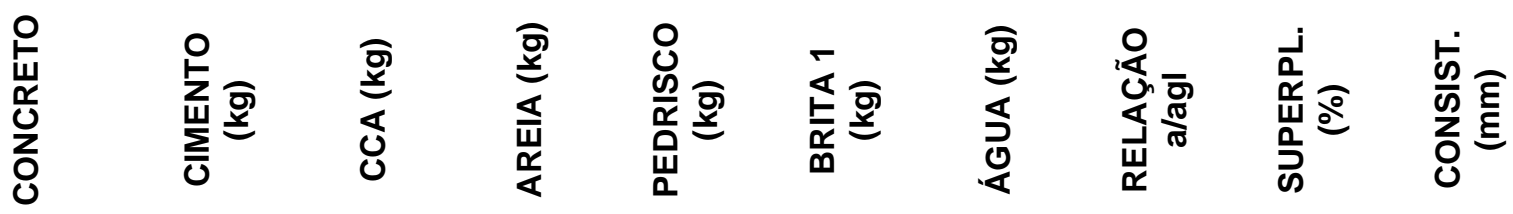

\begin{tabular}{llllllllll}
\hline PLUS-1:3,5 & 490 & --- & 679 & 311 & 725 & 221 & 0,44 & --- & 150 \\
\hline PLUS-1:5 & 386 & --- & 841 & 327 & 762 & 174 & 0,44 & 0,7 & 140 \\
\hline PLUS-1:6,5 & 319 & --- & 949 & 337 & 787 & 144 & 0,465 & 1,2 & 120 \\
\hline CCA-1:3,5 & 413 & 73 & 673 & 308 & 720 & 219 & 0,44 & 0,5 & 130 \\
\hline CCA-1:5 & 326 & 57,6 & 837 & 325 & 758 & 173 & 0,44 & 0,85 & 160 \\
\hline CCA-1:6,5 & 269 & 47,5 & 943 & 335 & 782 & 143 & 0,465 & 1,6 & 120 \\
\hline
\end{tabular}


A ordem de colocação dos materiais na betoneira em movimento é um importante parâmetro a ser considerado. A alteração da seqüência dos materiais, como comprova Castro (2007) provoca mudanças significativas na reologia do concreto. O ACl 211.4R-93 comenta que, segundo alguns estudos, resultados melhores foram obtidos com a adição do superplastificante por último. Tendo em vista estas afirmações, foi mantida em todas as misturas a mesma seqüência de colocação que é a seguinte:

- Imprimação

- Agregados graúdos;

- $\quad 100 \%$ da cinza da casca de arroz + $20 \%$ da água (dopagem);

- $100 \%$ da areia;

- $100 \%$ do cimento $+70 \%$ da água;

- Aditivo superplastificante mais o restante de água.

Foram moldados corpos-de-prova cilíndricos, em formas metálicas de $10 \mathrm{~cm} \times 20 \mathrm{~cm}$ (diâmetro x altura), conforme sugerido pela NBR 5738:1994 (Moldagem e cura de corpos-de-prova cilíndricos ou prismáticos de concreto). Quanto ao método de adensamento empregado, foi feito um estudo comparativo moldando-se 2 corpos-deprova manualmente e 2 com equipamento vibratório. Ambos propiciaram um bom acabamento da superfície e mesma resistência à compressão aos 7 dias. O processo de adensamento automático com vibrador de agulha de $5 \mathrm{~cm}$ de diâmetro foi adotado pela maior rapidez de moldagem que proporciona em relação ao método manual.

A capacidade resistente do material utilizado para a regularização dos topos dos corpos-de-prova de concreto ou argamassa de alto desempenho pode afetar 
os resultados obtidos no ensaio. Peterman e Carrasquillo (1986) apud Dal Molin (1995), sugerem que o capeamento seja feito com um composto de resistência mais alta, uma vez que os convencionais, de enxofre, não suportam resistência acima de $70 \mathrm{MPa}$. Se a resistência à compressão ou módulo de deformação do material de capeamento for menor que o do corpo-de-prova de concreto, as cargas aplicadas através do capeamento não serão transmitidas uniformemente, resultando em uma grande variabilidade nos resultados. A escolha utilizada nesta pesquisa para evitar problemas desta natureza foi a retificação com ferramenta abrasiva, seguindo orientações da NBR 5738:1994.

\subsection{ENSAIOS MECÂNICOS DOS CONCRETOS COM CCA}

\subsubsection{Resistência à compressão axial}

Os ensaios de resistência à compressão foram realizados com corpos-deprova cilíndricos de $10 \times 20 \mathrm{~cm}$ com as misturas citadas na Tabela 27 , conforme a NBR 5739:1994 (Concreto: ensaio de compressão de corpos-de-prova cilíndricos).

Os corpos-de-prova de concreto foram rompidos à compressão nas idades de 3, 7, 28 e 60 dias. Foram ensaiados 3 exemplares de cada traço por idade.

\subsubsection{Módulo de elasticidade}

A partir do ensaio da NBR 8522:1984, determinou-se os módulos de elasticidade secante dos seis traços de concreto da Tabela 27 aos 60 dias. 


\subsubsection{Resistência à tração por compressão diametral}

O ensaio foi realizado com as misturas da Tabela 27 em corpos-de-prova cilíndricos de $10 \times 20 \mathrm{~cm}$ e ensaiados na idade de 28 dias. Foram rompidos 2 corpos-deprova de cada mistura.

A NBR 6118:2003 se refere a este valor como resistência à tração indireta $\left(f_{c t, s p}\right)$. A resistência à tração direta $\left(f_{c t}\right)$ pode ser considerada igual a $0,9 f_{c t, s p}$.

\subsection{ENSAIOS MICROSCÓPICOS}

Para caracterização complementar e observação das várias fases da hidratação e morfologia dos produtos, serão realizadas análises da microestrutura de amostras fraturadas somente do concreto com traço 1:5 nas idades de 1, 3, 7, 18, 28, 60 e 90 dias.

As técnicas utilizadas para a análise microscópica são Microscopia eletrônica de varredura e a espectrografia por dispersão de energias.

A difração de raios-X foi utilizada para a análise da composição química da cinza da casca de arroz.

\subsubsection{Microscopia Eletrônica de Varredura}

Microscopia eletrônica de varredura (MEV) é uma técnica que se baseia no rastreamento da superfície da amostra por um fino feixe de elétrons. O princípio desta técnica é fundamentado na emissão de um feixe de elétrons por um filamento de tungstênio, que concentrado, controlado e reduzido por um sistema de lentes 
eletromagnéticas, diafragmas e bobinas, incide sobre uma amostra provocando uma série de emissões de sinais relacionados com a interação do feixe de elétrons e a amostra.

No microscópio eletrônico de varredura, qualquer superfície boa condutora elétrica e estável em vácuo pode ser analisada com adequada profundidade de foco. Materiais isolantes devem ser recobertos com uma fina camada de material condutor. (ISAIA, 2005).

Acoplados ao MEV, detectores e sistemas de análises de raios-X emitidos da interação do feixe com a amostra possibilitam a análise qualitativa, semiqualitativa e quantitativa dos elementos presentes na superfície da amostra (ROSSIGNOLO, 2003).

A técnica foi utilizada para visualização das mudanças ao decorrer do desenvolvimento da hidratação nas idades de 1,3, 7, 28, 60 e 90 dias de amostras de concreto do traço 1:5 com adição de 15\% de CCA e relação água-aglomerante igual a 0,45. Esta análise associada a EDS, comentada a seguir, possibilita um melhor entendimento da estrutura interna do concreto e o conhecimento do aspecto geral da pasta e da zona de transição, além de seus vazios, tamanho e morfologia dos seus produtos de hidratação.

\subsubsection{Espectrografia por Dispersão de Energias}

A espectrografia por dispersão de energias (EDS) é utilizada em associação a sistemas de análise de raios-X. Ela permite realizar a análise química elementar em um ponto ou em uma área da amostra em termos qualitativos, semiquantitativos e quantitativos. A identificação e a determinação da composição de 
um elemento são feitas pela comparação da intensidade das riscas espectrais características da amostra com espectros de referência contidos em bancos de dados.

Como a análise pontual por EDS atua num volume de alguns micrômetros cúbicos e as dimensões das partículas dos produtos das reações de hidratação do cimento variam entre alguns nanômetros e um micrômetro, os resultados de uma análise pontual representam a mistura de vários produtos de hidratação com diferentes tipos de composição. Assim, a determinação da composição de uma fase específica torna-se pouco precisa. Entretanto, pode-se obter uma estimativa da composição dos principais produtos da hidratação do cimento, como $\mathrm{CH}$, C-S-H, AFt e Afm, em uma análise pontual pelas relações entre as massas atômicas de alguns óxidos presentes nesta análise, como $\mathrm{SiO}_{2}, \mathrm{CaO}, \mathrm{Fe}_{2} \mathrm{O}_{3}, \mathrm{Al}_{2} \mathrm{O}_{3}$ e $\mathrm{SO}_{3}$ (ROSSIGNOLO, 2003).

\subsubsection{Preparação das amostras}
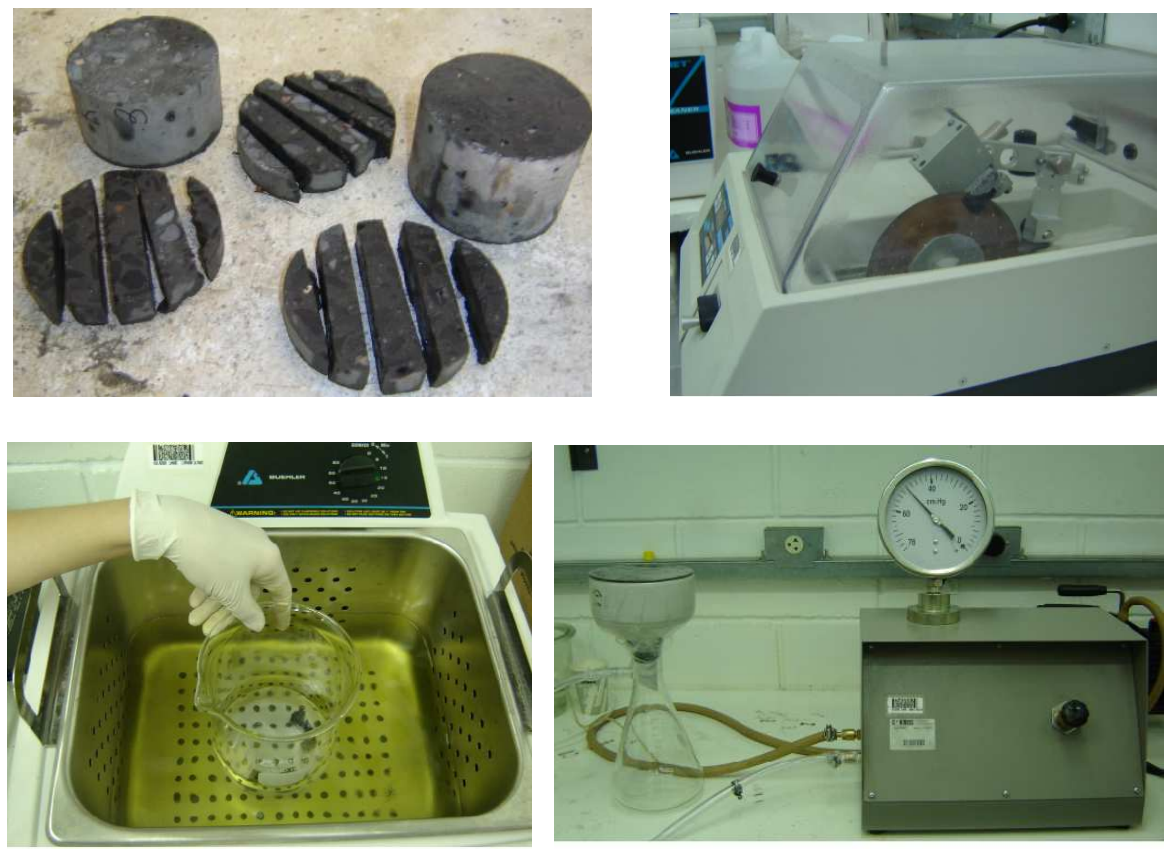

Figura 62: Preparação de amostras. 
As amostras fraturadas foram preparadas a partir de corpos-de-prova de $100 \mathrm{~mm} \times 200 \mathrm{~mm}$ (diâmetro $\times$ altura) de concreto com traço 1:5 (conforme Tabela 29), relação água-aglomerante de 0,45 . As amostras foram cortadas em fatias com $20 \mathrm{~mm}$ de espessura com disco de corte. Em seguida, cortou-as em fatias de maneira que a amostra ficasse com o formato de pequenos prismas de $10 \mathrm{~mm} \times 10 \mathrm{~mm}$ de base com serra diamantada de baixa rotação, lubrificada com álcool isopropílico. Os pequenos prismas são então seccionados para formar a superfície fraturada. Se necessário, as amostras são serradas para adquirirem o formato de $10 \times 10 \times 10 \mathrm{~mm}$. As amostras, agora com formato cúbico, são colocadas em copo de Becker com álcool isopropílico e levadas ao ultra-som por 15 minutos para que sejam limpas. Em seguida são levadas ao dessecador a vácuo por 5 minutos, e depois ao agitador por 20 minutos. As últimas duas etapas são repetidas por mais 2 vezes, quando então a amostra é levada uma última vez ao dessecador e, finalmente à estufa com temperatura de $60^{\circ} \mathrm{C}$ por 24 horas. A amostra passa então por um banho de ouro, que atuará como material condutor.

\subsubsection{Difração de Raios-X}

A análise de Difração de Raios-X (DRX) tem caráter qualitativo, uma vez que está baseada na identificação das fases cristalinas presentes nas pastas, realizada por análise dos picos presentes no difratograma e comparação com bancos de dados específicos. Permite avaliação sobre quanto uma amostra é amorfa ou cristalina. 


\section{ANÁLISE DE RESULTADOS}

A análise de resultados será realizada por comparação entre os materiais e misturas desta pesquisa e também com outros resultados de trabalhos publicados relacionados à cinza da casca de arroz e outros tipos de sílicas ativas. As constituições cimentícias serão classificadas de acordo com normas específicas e publicações consagradas relacionadas aos cimentos Portland comerciais e materiais pozolânicos.

\subsection{ENSAIOS DE QUALIDADE DO “NOVO CIMENTO”}

\subsubsection{Caracterização da CCA}

Sua composição química foi realizada no CCDM - UFSCar/ UNESP. O resultado está exposto na Tabela 28.

\begin{tabular}{|c|c|}
\hline ELEMENTO & RESULTADO (\%) \\
\hline $\mathrm{SIO}_{2}$ & 88,37 \\
\hline $\mathrm{Al}_{2} \mathrm{O}_{3}$ & 0,30 \\
\hline $\mathrm{Fe}_{2} \mathrm{O}_{3}$ & 0,25 \\
\hline $\mathrm{TiO}_{2}$ & 0,01 \\
\hline $\mathrm{CaO}$ & 0,76 \\
\hline $\mathrm{MgO}$ & 0,79 \\
\hline $\mathrm{Na}_{2} \mathrm{O}$ & 0,18 \\
\hline $\mathrm{K}_{2} \mathrm{O}$ & 1,02 \\
\hline $\mathrm{P}_{2} \mathrm{O}_{5}$ & 0,65 \\
\hline $\mathrm{MnO}$ & 0,25 \\
\hline $\mathrm{Cr}_{2} \mathrm{O} 5$ & -- \\
\hline $\mathrm{ZrO}_{2}$ & -- \\
\hline Perda ao Fogo - PF & 7,44 \\
\hline
\end{tabular}


Segundo a NBR 12653:1992, a CCA pode ser classificada como um material pozolânico do tipo E. Esta norma prescreve limites para propriedades químicas e físicas demonstradas nas Tabelas 29 e 30, respectivamente.

Tabela 29: Propriedades químicas dos materiais pozolânicos.

\begin{tabular}{lcc}
\multicolumn{1}{c}{ Tabela 29: Propriedades químicas dos materiais pozolânicos. } & \\
\hline PROPRIEDADES & $\begin{array}{c}\text { LIMITE DA NBR } \\
\mathbf{1 2 6 5 3 : 1 9 9 2}\end{array}$ & CCA \\
\hline $\mathrm{SiO}_{2}+\mathrm{Al}_{2} \mathrm{O}_{3}+\mathrm{Fe}_{2} \mathrm{O}_{3}$ (\% mín.) & 50 & 88,92 \\
\hline Perda ao fogo (\% máx.) & 6,0 & 7,44 \\
\hline Alcalis disponíveis em $\mathrm{Na}_{2} \mathrm{O}$ (\% máx.) & 1,5 & 0,18 \\
\hline
\end{tabular}

Com relação às propriedades químicas, percebe-se que a CCA da termoelétrica do RS atende os requisitos quanto aos óxidos e a quantidade de álcalis em $\mathrm{Na}_{2} \mathrm{O}$, mas não atende a prescrição quanto à perda ao fogo, indicando um alto teor de carbono. Apesar de não estar em acordo com a norma, a perda ao fogo serve apenas como um limitante na fração de CCA num aglomerante. Como no caso deste estudo, a proporção máxima utilizada é de $15 \%$ e a perda ao fogo do cimento CPV-ARI PLUS é de apenas $1,32 \%$, esta propriedade não representa um problema.

O equivalente de álcalis para a CCA é de 1,03\%, valor este maior que o máximo recomendado de $0,6 \%$. Da mesma forma que a perda ao fogo, os álcalis da CCA representam no máximo $15 \%$ do total em massa do aglomerante. Mesmo assim, é essencial a utilização de agregados não reativos, como os empregados neste trabalho.

Tabela 30: Propriedades físicas dos materiais pozolânicos.

\begin{tabular}{|c|c|c|}
\hline PROPRIEDADES & $\begin{array}{c}\text { LIMITE DA NBR } \\
12653: 1992\end{array}$ & CCA \\
\hline Material retido na peneira $45 \mu \mathrm{m}$ (\% máx.) & 34 & 1,3 \\
\hline IAP com cimento (\% mín) & 75 & 96,4 \\
\hline IAP com cal (mín. em MPa) & 6,0 & 4,1 \\
\hline Agua requerida (\% máx.) & 110 & 111,2 \\
\hline
\end{tabular}

Quanto às propriedades físicas, alguns resultados demonstram que a fração de CCA deve ser controlada. Em relação à quantidade de material retido na 
peneira ํo 325 (abertura de $45 \mu \mathrm{m}$ ), o valor encontrado é muito inferior ao especificado, o que indica que a CCA é muito mais fina que o requerido. Mesmo na peneira № 400 (abertura de $37 \mu \mathrm{m}$ ), somente $1,55 \%$ do material ficou retido. Quanto à atividade pozolânica, o índice de pozolanicidade com o cimento foi $28,5 \%$ superior ao requerido, já com a cal a CCA não atingiu o mínimo necessário. O hidróxido de cálcio resultante da hidratação do cimento e o utilizado neste ensaio são diferentes, o que explica por que com o cimento a CCA teve resultados excelentes e com o hidróxido de cálcio puro o mesmo não aconteceu. $O$ ensaio de determinação do IAP com a cal é fortemente afetado pela quantidade de água que, conseqüentemente, influencia o resultado final. A atividade pozolânica da cinza com o cimento será melhor discutida adiante. Quanto à água requerida, o valor encontrado é $1,1 \%$ superior ao especificado. Isto não é preocupante porque a cinza será utilizada em frações de até $15 \%$ da massa do aglomerante. $\mathrm{O}$ índice de atividade pozolânica com a cal calculado de acordo com a NBR 5751:1992, como já mencionado, foi inferior ao valor prescrito pela NBR 12653:1992.

O DRX realizado do cinza da casca de arroz forneceu o seguinte resultado:

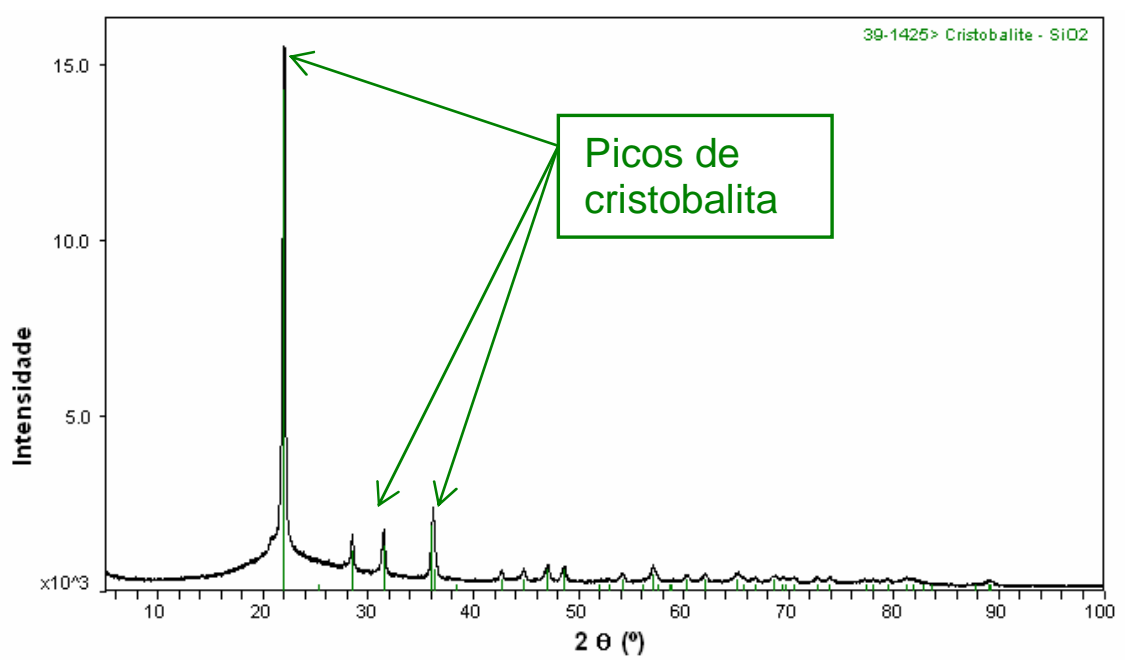

Figura 63: Difratograma da CCA. 
No difratograma percebem-se vários picos de cristobalita, indicando que o material é predominantemente cristalino. Isto confirma a teoria que afirma que, quando a cinza da casca de arroz é submetida a temperaturas acima de $900^{\circ} \mathrm{C}$, como é o caso (aproximadamente $1000^{\circ} \mathrm{C}$ ), a CCA torna-se cristalina. É conhecido que a cinza amorfa é mais reativa. Entretanto, para se obter a cinza amorfa é preciso tratar a casca de arroz em fornos especiais com temperatura controlada. Isto significa em aumento de custos de produção, já a cinza da casca de arroz da termoelétrica aparece como um resíduo do processo de parboilização.

Quanto à granulometria, a cinza apresentou diâmetro médio das partículas de $13,38 \mu \mathrm{m}$ no ensaio a laser realizado pela Faber-Castell. A curva granulométrica está apresentada na Figura 64.

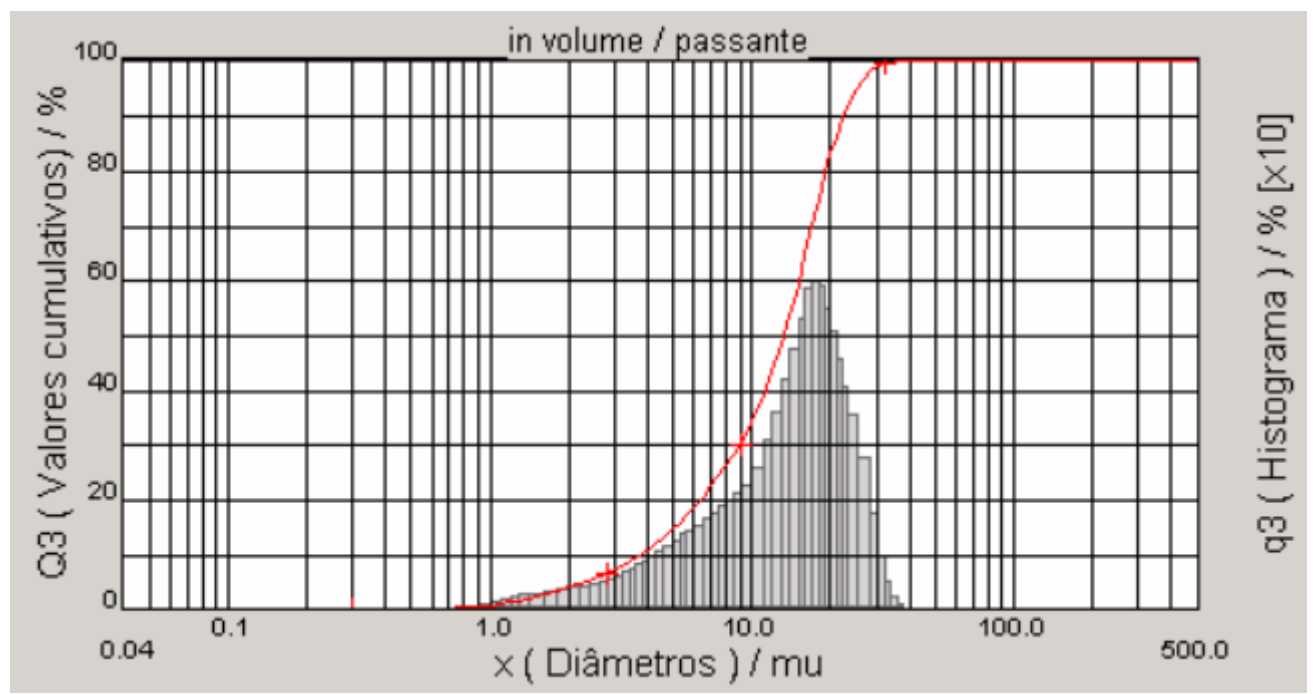

Figura 64: Curva granulométrica da CCA.

A área específica superficial da cinza de casca de arroz moída na indústria foi de $14,3023 \mathrm{~m}^{2} / \mathrm{g}$. O laboratório que executou o ensaio foi o do curso de Engenharia Metalúrgica e de Materiais da USP e o método adotado foi o por absorção de nitrogênio (BET). A Tabela 31 mostra valores de áreas específicas de vários 
materiais pozolânicos. Observa-se que a área específica da CCA é muito maior que a do cimento CPV-ARI PLUS e um pouco maior que a da sílica de ferro-silício. Nota-se que com o tratamento térmico é possível dobrar a área específica e com o tratamento químico o aumento pode ser de cerca de $550 \%$.

Tabela 31: Área específica de alguns materiais.

Fontes: Balthar (2004), Costenaro (2003) adaptado.

\begin{tabular}{lc}
\multicolumn{1}{c}{ MATERIAIS } & $\begin{array}{c}\text { ÁREA ESPECÍFICA } \\
\left(\mathbf{m}^{2} / \mathbf{g}\right)\end{array}$ \\
\hline Sílica branca da casca de arroz & 93,6 \\
\hline Cinza da casca de arroz com queima controlada $\left(300^{\circ} \mathrm{C}\right)$ & 30,8 \\
\hline Metacaulinita & 23,1 \\
\hline Cinza da casca de arroz de termoelétricas do RS & 14,3 \\
\hline Sílica ativa de ferro-silício & 10 \\
\hline Cimento CPV-ARI PLUS & 0,49 \\
\hline
\end{tabular}

A pozolanicidade da CCA foi medida pelo método Chapelle modificado. A cinza de casca de arroz que será utilizada neste estudo é considerada de alto efeito pozolânico, pois apresentou uma pozolanicidade de $99,80 \%$, ou seja, há um consumo do material alcalino $(\mathrm{CaO})$ de quase 3 vezes o valor mínimo, que é de $33 \%$. A Tabela 32 traz valores de pozolanicidade de outros materiais pelo método de Chapelle modificado. Em comparação com outros materiais a cinza da casca de arroz teve excelente resultado, apresentando pozolanicidade igual a das sílicas de ferro-silício e a da casca de arroz.

Tabela 32: Pozolanicidade pelo método de Chapelle modificado.

Fonte: Costenaro (2003) adaptado.

\begin{tabular}{lr}
\hline Cinza da Casca de arroz de termoelétricas do RS & $99,80 \%$ \\
\hline Sílica ativa de ferro-silício & $99,79 \%$ \\
\hline Sílica branca da casca de arroz & $99,75 \%$ \\
\hline Cinza da casca de arroz com queima controlada $\left(300^{\circ} \mathrm{C}\right)$ & $99,54 \%$ \\
\hline
\end{tabular}

O índice de atividade pozolânica com o cimento calculado de acordo com a NBR 5752:1992, como já mencionado, supera o valor prescrito pela NBR 12653:1992. A Tabela 33 mostra IAP com o cimento e a água requerida de alguns materiais. A 
extrema finura dessa pozolana fez com que a quantidade de água necessária para obtenção de uma consistência padrão de $225 \pm 5 \mathrm{~mm}$ ultrapassasse o limite máximo de $110 \%$ da NBR 12653. A excessiva demanda de água dessa argamassa demonstra que o uso dessa pozolana em proporções maiores em misturas de concretos de alto desempenho, assim como o da sílica ativa, está vinculado ao emprego de aditivos plastificantes e superplastificantes. Contudo, este resultado não permite que a diferença de reatividade entre as pozolanas seja efetivamente avaliada em virtude das relações água-aglomerante das argamassas não terem sido as mesmas, tendo em vista a diferença de finura entre as pozolanas, requerendo assim quantidades de água distintas para a obtenção de uma consistência padrão. Além disso, o cimento utilizado na argamassa de referência também variou. No estudo de Barata e Dal Molin (2002), por exemplo, foi utilizado CPII F 32, enquanto que nesse estudo o cimento empregado é o CPV-ARI PLUS. Por estas razões, o ensaio de Chapelle é mais adequado na comparação entre as atividades pozolânicas de materiais distintos.

Tabela 33: Índice de atividade pozolânica com o cimento.

Fonte: Barata e Dal Molin (2002) e Moura (2000) adaptado.

\begin{tabular}{lcc}
\hline \multicolumn{1}{c}{ MATERIAL } & IAP com o cimento & Água requerida \\
\hline Sílica ativa de ferro-silício & $103,63 \%$ & $132,30 \%$ \\
\hline Metacaulinita & $102,68 \%$ & $129,12 \%$ \\
\hline Cinza da Casca de arroz de termoelétricas do RS & $96,4 \%$ & $111,2 \%$ \\
\hline Material cerâmico de demolição & $87,2 \%$ & -- \\
\hline Escória de cobre & $87,0 \%$ & $98 \%$ \\
\hline
\end{tabular}

\subsubsection{Tempos de pega}

Os ensaios em pastas para determinação dos tempos de pega foram realizados segundo a NBR 11581:1991. Os resultados encontrados estão expostos na Tabela 34 e na Figura 65. 
Tabela 34: Tempos de início e fim de pega de pastas com CCA.

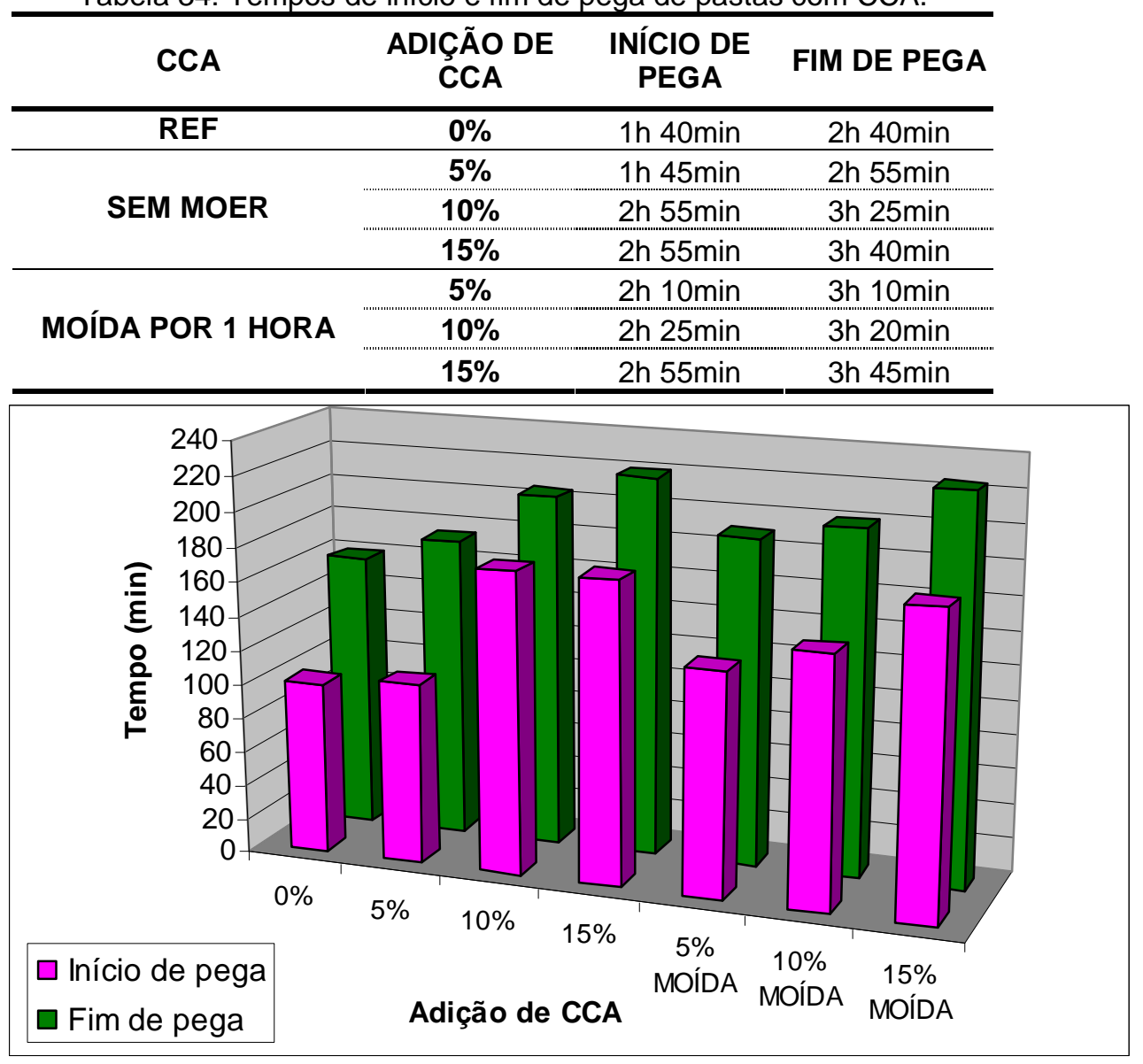

Figura 65: Gráfico de tempos de início e fim de pega de pastas com CCA.

Os resultados demonstram uma sensível melhora nos tempos de pega com a adição da CCA. O início de pega é postergado com o aumento da adição de CCA, chegando a uma diferença de $1: 15 \mathrm{~h}$ de atraso no caso de pastas com $15 \%$ de adição de CCA em relação à mistura de referência. Para os tempos de fim de pega, o comportamento é o mesmo. Isto pode ser explicado pela substituição de um material que reage rapidamente, ou seja, o cimento ARI, por um material pozolânico.

O início de pega das misturas com a CCA mais fina não ocorreu antes da mais grossa. Santos (1997) comenta que a cinza da casca de arroz teria um tempo ótimo de moagem, a partir do qual, sua área específica decresce em vez de aumentar. 
A moagem de 1 hora adicional à moagem industrial não se mostrou eficiente para aumentar a rapidez do início das reações.

O tempo de início de pega mínimo estabelecido pelas normas NBR 11578:1991 (Cimento Portland composto) e NBR 5733:1991 (Cimento Portland de alta resistência inicial) é de 1 hora, e o tempo máximo de fim de pega é de 10 horas. Todas as misturas estão de acordo com as normas.

Em relação ao calor de hidratação, pelo simples manuseio das amostras foi possível notar um decréscimo significativo de temperatura no momento de fim de pega para as misturas com maiores teores de CCA.

\subsubsection{Resistência à compressão de argamassas padrões}

O ensaio de resistência à compressão é realizado com corpos-de-prova cilíndricos de $5 \times 10 \mathrm{~cm}$ com as amostras de argamassa padrão saturadas com a superfície seca, conforme NBR 7215:1991. As idades ensaiadas foram: 24h, 3, 7, 14, 28,56 e 91 dias. As tabelas com os resultados dos ensaios de resistência à compressão das argamassas padrão estão apresentados no Anexo A e os diagramas resistência à compressão x idade estão apresentados nas Figuras de 66 a 70, sendo as duas primeiras comparações das argamassas com diferentes frações de CCA, e as três últimas comparações entre argamassas com mesma fração de CCA, mas diferentes finuras.

O critério utilizado para descartar resultados suspeitos foi o de Chauvenet que diz que se em uma série de $n$ medições, a probabilidade de a ocorrência de um 
valor x é menor que $\frac{1}{2 \cdot n}$, então a medição que apresentar tal desvio deverá ser rejeitada.

Os resultados foram submetidos à análise de variância e, conforme pode ser observado na Tabela 35, as médias são realmente diferentes, o que permite que elas possam ser utilizadas diretamente na análise de resultados.

Tabela 35: Planilha de análise de variância.

\begin{tabular}{|c|c|c|c|c|c|c|c|c|}
\hline \multicolumn{8}{|c|}{ TEOR DE CCA } & \\
\hline Teor & \multicolumn{2}{|c|}{$5 \%$} & \multicolumn{2}{|c|}{$10 \%$} & \multicolumn{2}{|c|}{$15 \%$} & $\mathbf{S}$ & \\
\hline \multirow{2}{*}{ Moagem industrial } & 31,39 & 29,72 & 26,99 & 29,18 & 24,60 & 27,87 & \multirow{2}{*}{339,01} & \\
\hline & 29,10 & 27,81 & 27,25 & 28,06 & 27,93 & 29,11 & & \\
\hline \multirow{2}{*}{ Moída por 1 hora } & 28,11 & 30,27 & 20,22 & 19,33 & 19,28 & 18,84 & \multirow{2}{*}{277,02} & \\
\hline & 30,52 & 31,29 & 20,60 & 19,31 & 19,18 & 20,07 & & $\bar{C}$ \\
\hline $\mathbf{S}$ & \multicolumn{2}{|c|}{238,21} & \multicolumn{2}{|c|}{190,94} & \multicolumn{2}{|c|}{186,88} & 616,03 & 15812,21 \\
\hline Fonte Var. & g.l. & $\mathrm{S}^{2}$ & Q.M & $\mathbf{R}$ & $\mathbf{F}_{\text {crit }}{ }^{*}$ & $\mathbf{S}$ & Resultado & \\
\hline Teor & 2 & 203,57 & 101,79 & 64,39 & 3,55 & $5 \%$ & $\overline{\mathrm{OK}}$ & \\
\hline Moagem & 1 & 160,12 & 160,12 & 101,29 & 4,41 & $5 \%$ & OK & \\
\hline Teor + moagem & 2 & 97,76 & 48,88 & 30,92 & 3,55 & $5 \%$ & $\mathrm{OK}$ & \\
\hline Entre Trat. & 5 & 461,44 & 92,29 & \multicolumn{4}{|c|}{ OK - há diferença entre as médias } & \\
\hline Residual & 18 & 28,45 & 1,58 & \multicolumn{4}{|c|}{ N. OK. - Não há diferença entre as médias } & \\
\hline Total & 23 & 489,90 & & \multicolumn{4}{|c|}{${ }^{*}$ Vem da tabela de distribuição $\mathrm{F}$} & \\
\hline
\end{tabular}

Os resultados plotados nos gráficos representam a média aritmética das resistências dos exemplares válidos, ou seja, que não foram descartados.

Os gráficos das Figuras 66 e 67 demonstram um desenvolvimento mais tardio da resistência à compressão das misturas a medida que cresce a fração de CCA nas primeiras idades (1, 3 e 7 dias). A argamassa de referência é a que obteve melhores resultados nas primeiras idades em todos os casos. Isto pode ser entendido pelo comportamento pozolânico da CCA, pois quando há substituição de parte do cimento Portland pela pozolana, há perda de $\mathrm{C}_{3} \mathrm{~S}$, composto do cimento de hidratação mais rápida. Além disso, a reação pozolânica da CCA é mais lenta. Este resultado está em acordância com os encontrados por diversos autores (MALHOTRA e MEHTA, 1996; ZHANG e MALHOTRA, 1996; RODRIGUEZ e DAL MOLIN, 1999; SENSALE, 2000). 
Entretanto o ganho da resistência nas primeiras idades foi mais significativo quando a comparação é entre as misturas com cinza da casca de arroz moída por 1 hora (Figura 67). Com idade de 1 dia a diferença entre a resistência da argamassa de referência e a com $15 \%$ de adição de CCA moída foi de 32,9\%, já na CCA sem moer esta diferença foi de apenas 5,0\%. Na maioria dos trabalhos com cinzas de diversas origens e tratamentos, este ganho de resistência em relação à referência não é grande, algumas vezes apresentam, até mesmo, valores iguais.

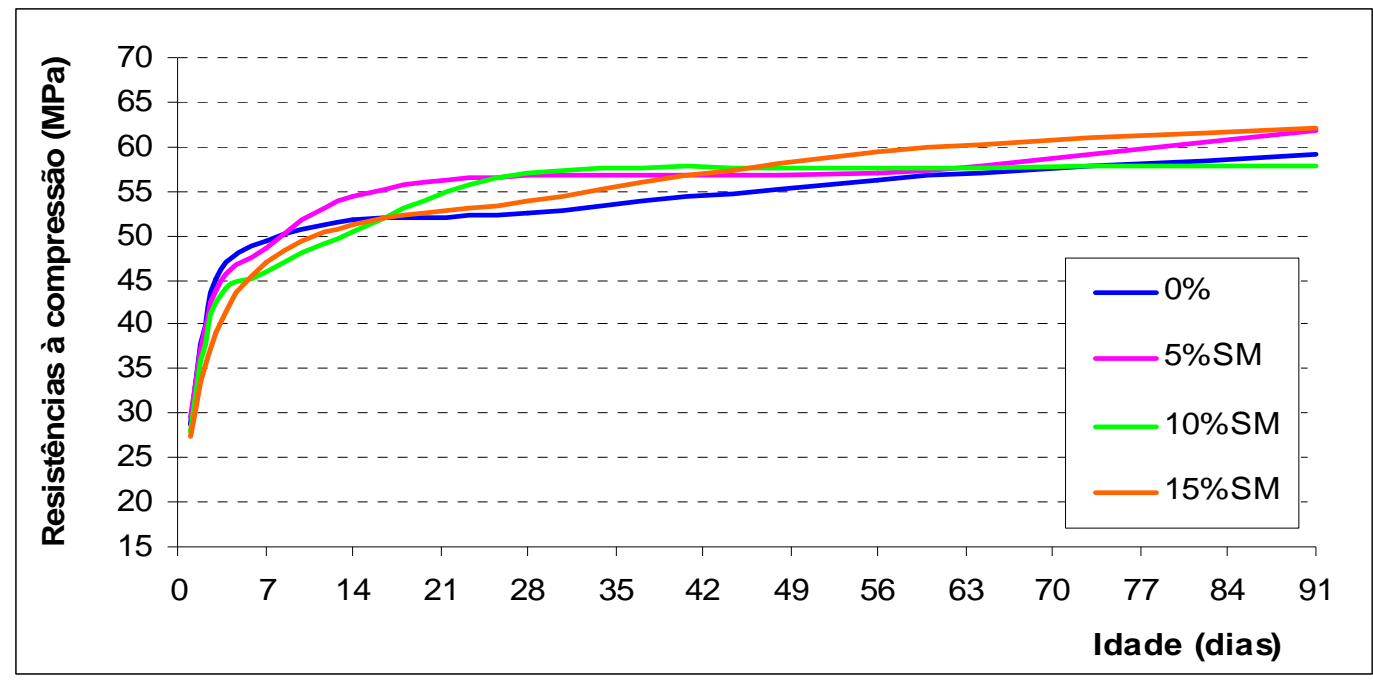

Figura 66: Gráfico de resistência à compressão de argamassas com CCA sem moer.

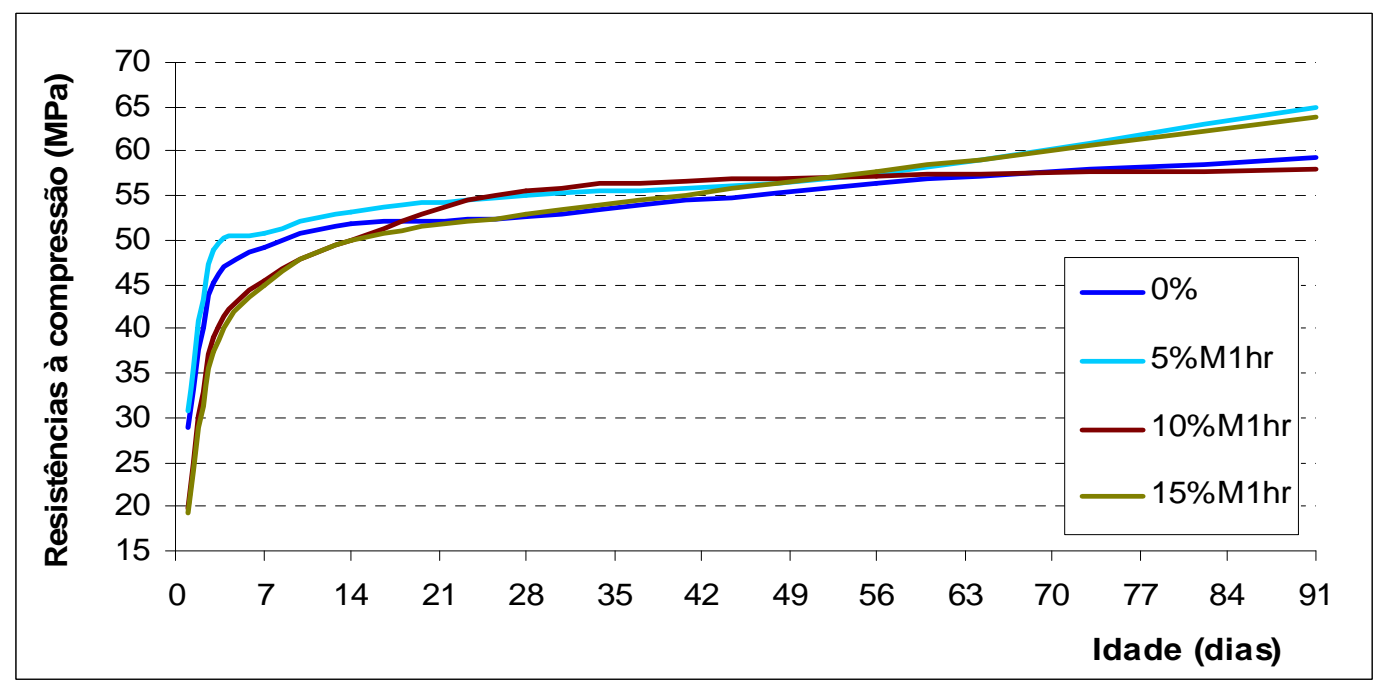

Figura 67: Gráfico de resistência à compressão de argamassas com CCA moída por 1h. 


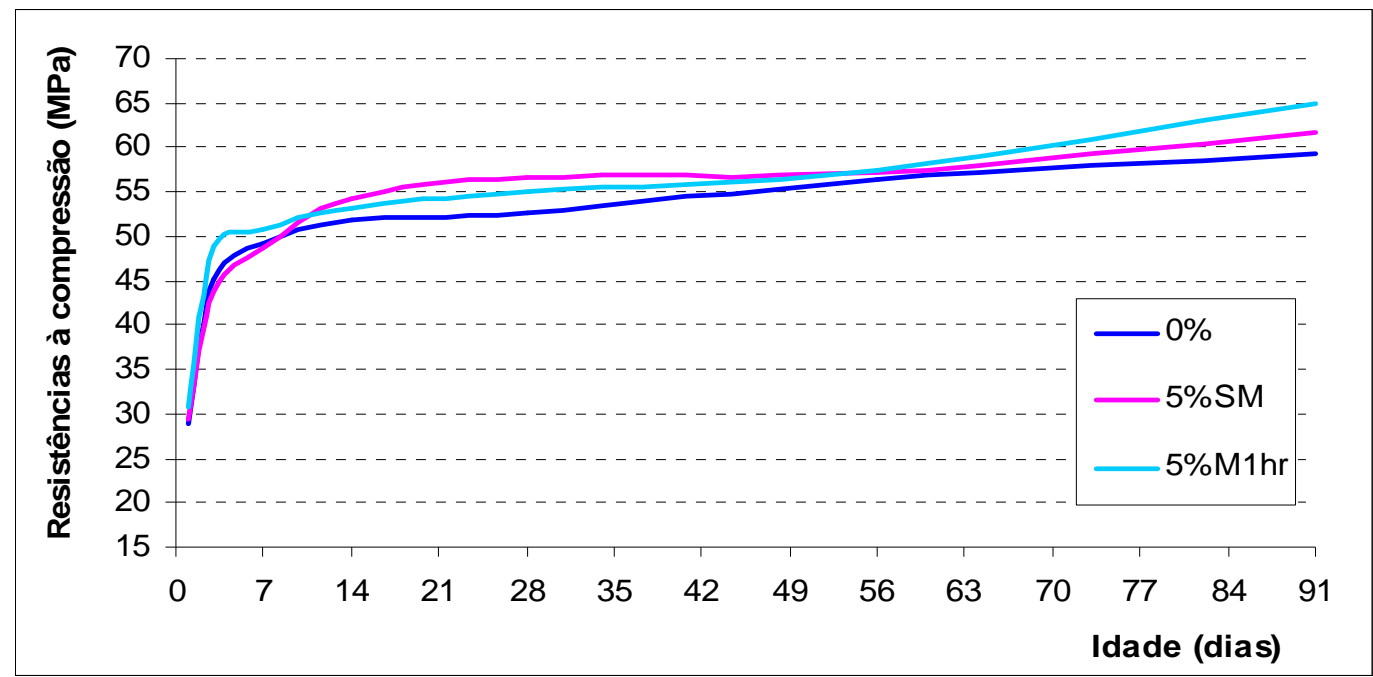

Figura 68: Gráfico de resistência à compressão de argamassas com 5\% de CCA e REF.

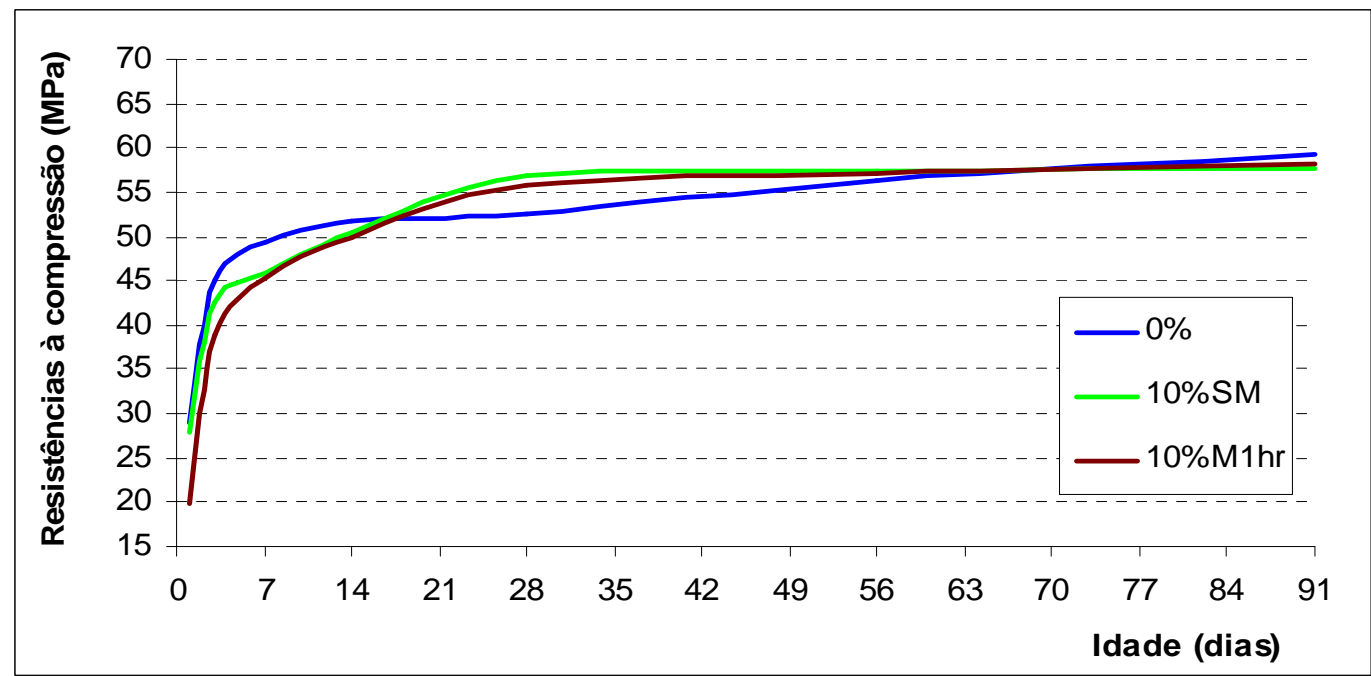

Figura 69: Gráfico de resistência à compressão de argamassas com 10\% de CCA e REF.

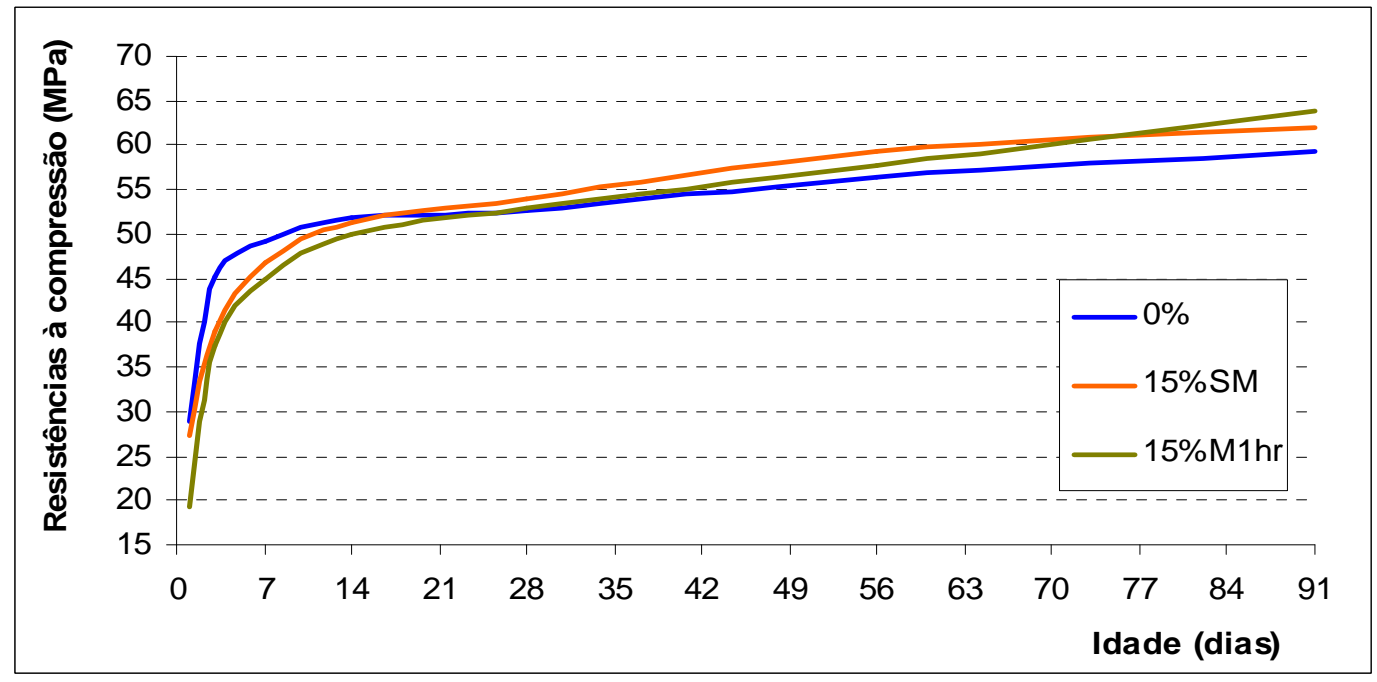

Figura 70: Gráfico de resistência à compressão de argamassas com 15\% de CCA e REF. 
Ainda com relação às Figuras 66 e 67, no 14ํ dia o valor das resistências nas argamassas com maior quantidade de CCA começam a ultrapassar as resistências das argamassas com menores quantidades. A partir daí as misturas que obtiveram maior desempenho foram as com $15 \%$ de CCA e com $5 \%$ de CCA, sucessivamente tanto para as misturas com a cinza industrial quanto para a moída por 1 hora. Estas proporções apresentam aos 91 dias de idade a sua curva com comportamento ascendente, demonstrando que estas misturas continuarão a desenvolver resistência à compressão em idades mais avançadas. As misturas com frações menores de CCA também apresentam curva ascendente, mas com tendência à estabilização. Alguns trabalhos que ensaiaram concretos com idades avançadas (148, 180 dias) à compressão mostraram que, mesmo nestas idades, continuava havendo acréscimo de resistência. Este comportamento também está de acordo com os trabalhos citados e demonstram que a reação da CCA, apesar de se dar com certo atraso, propicia ganhos de resistência à compressão pelos efeitos fíler e pozolânico inerentes a ela.

A argamassa com $10 \%$ de CCA obteve resultado inferior às outras misturas na idade de 91 dias provavelmente por problemas de causa humana (lembrando que a moldagem dos corpos-de-prova é feita manualmente efetuando-se golpes com um soquete) e/ou mecânico (a prensa apresentou problemas e parte dos ensaios foi realizada com outro equipamento).

Comparando os gráficos das Figuras 69 e 70, percebe-se que a cinza moída não propiciou ganho de resistência nas primeiras idades e sim perda, ao contrário do que se esperava por ser ela mais fina. Isto confirma a afirmação quanto aos tempos de pega que o tempo de moagem da CCA moída por mais 1 hora além da moagem industrial foi superior ao tempo ótimo de moagem, o que acarretou provavelmente em formação de amontoados de partículas que dificultaram a reação 
com o hidróxido de cálcio. Para a fração de 5\% deve ter ocorrido algum tipo de erro, ou humano e/ou mecânico. Nas idades mais avançadas, a cinza moída apresentou uma leve melhoria em comparação com a sem moer. É necessária uma análise mais completa sobre o tempo de moagem ótimo para estimar o melhor custo-benefício em relação à resistência à compressão.

Novamente nas Figuras 68, 69 e 70 percebe-se que o comportamento das argamassas com 10\% de CCA é inferior às demais.

As normas NBR 11578:1991 (Cimento Portland composto) e NBR 5733:1991 (Cimento Portland de alta resistência inicial) estabelecem como limitações as resistências de 1, 3, 7 e 28 dias. A Tabela 36 mostra as especificações das normas. Todas as misturas estão de acordo com ambas as normas (ver Anexo A).

Tabela 36: Especificações das normas NBR 11578 e NBR 5733.

\begin{tabular}{ccc}
\hline IDADE & $\begin{array}{c}\text { NBR 11578 }- \text { Cimento portland } \\
\text { composto }- \text { classe } \mathbf{4 0}\end{array}$ & $\begin{array}{c}\text { NBR 5733 - Cimento Portland } \\
\text { de alta resistência inicial }\end{array}$ \\
\hline $\mathbf{1}$ dia & -- & $\geq 14,0 \mathrm{MPa}$ \\
\hline $\mathbf{3}$ dias & $\geq 15,0 \mathrm{MPa}$ & $\geq 24,0 \mathrm{MPa}$ \\
\hline $\mathbf{7}$ dias & $\geq 25,0 \mathrm{MPa}$ & $\geq 34,0 \mathrm{MPa}$ \\
\hline $\mathbf{2 8}$ dias & $\geq 40,0 \mathrm{MPa}$ & -- \\
\hline
\end{tabular}

A análise de variância permite uma comparação sobre a significância e influência das variáveis em determinada propriedade, neste caso a resistência à compressão axial. A Tabela 37 mostra que tanto a variável teor de CCA como a moagem, influenciaram significativamente na resistência, pois ambas superaram bastante o valor unitário. A variável moagem se mostrou um pouco mais influenciadora.

Tabela 37: Planilha com razão $R / F_{\text {crit }}$ da análise de variância.

\begin{tabular}{|c|c|c|c|c|c|c|}
\hline & \multicolumn{2}{|c|}{ TEOR } & \multicolumn{2}{|c|}{ MOAGEM } & \multirow[b]{2}{*}{$\mathbf{R}_{\text {teor }} / \mathbf{F}_{\text {crit }}$} & \multirow[b]{2}{*}{$\mathbf{R}_{\text {moagem }} / \mathbf{F}_{\text {crit }}$} \\
\hline & $\mathbf{R}_{\text {teor }}$ & $\mathbf{F}_{\text {crit }}$ & $\mathbf{R}_{\text {moagem }}$ & $\mathbf{F}_{\text {crit }}$ & & \\
\hline $\begin{array}{ll}\text { Resistência } & \text { à } \\
\text { compressão } & \end{array}$ & 64,39 & 3,55 & 101,29 & 4,41 & 18,14 & 22,97 \\
\hline
\end{tabular}


6.1.4. Resistência à tração por compressão diametral de argamassas

As tabelas com os resultados dos ensaios de resistência à tração obtida pelo ensaio à compressão diametral das argamassas padrão estão apresentados no Anexo $A$ e os diagramas resistência à compressão $x$ idade estão apresentados nas Figuras 71 e 72.

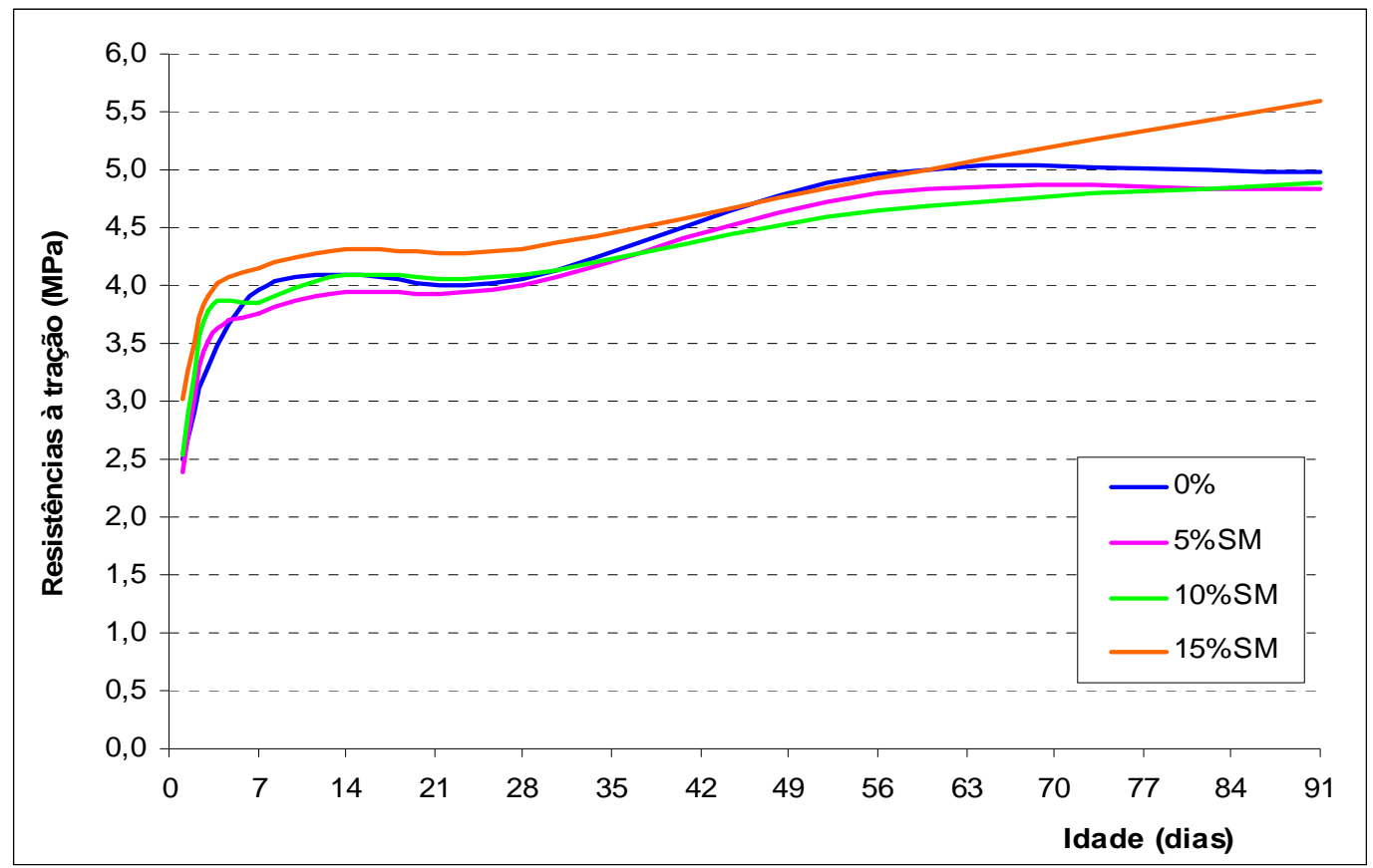

Figura 71: Gráfico de resistência à tração de argamassas com CCA sem moer. 


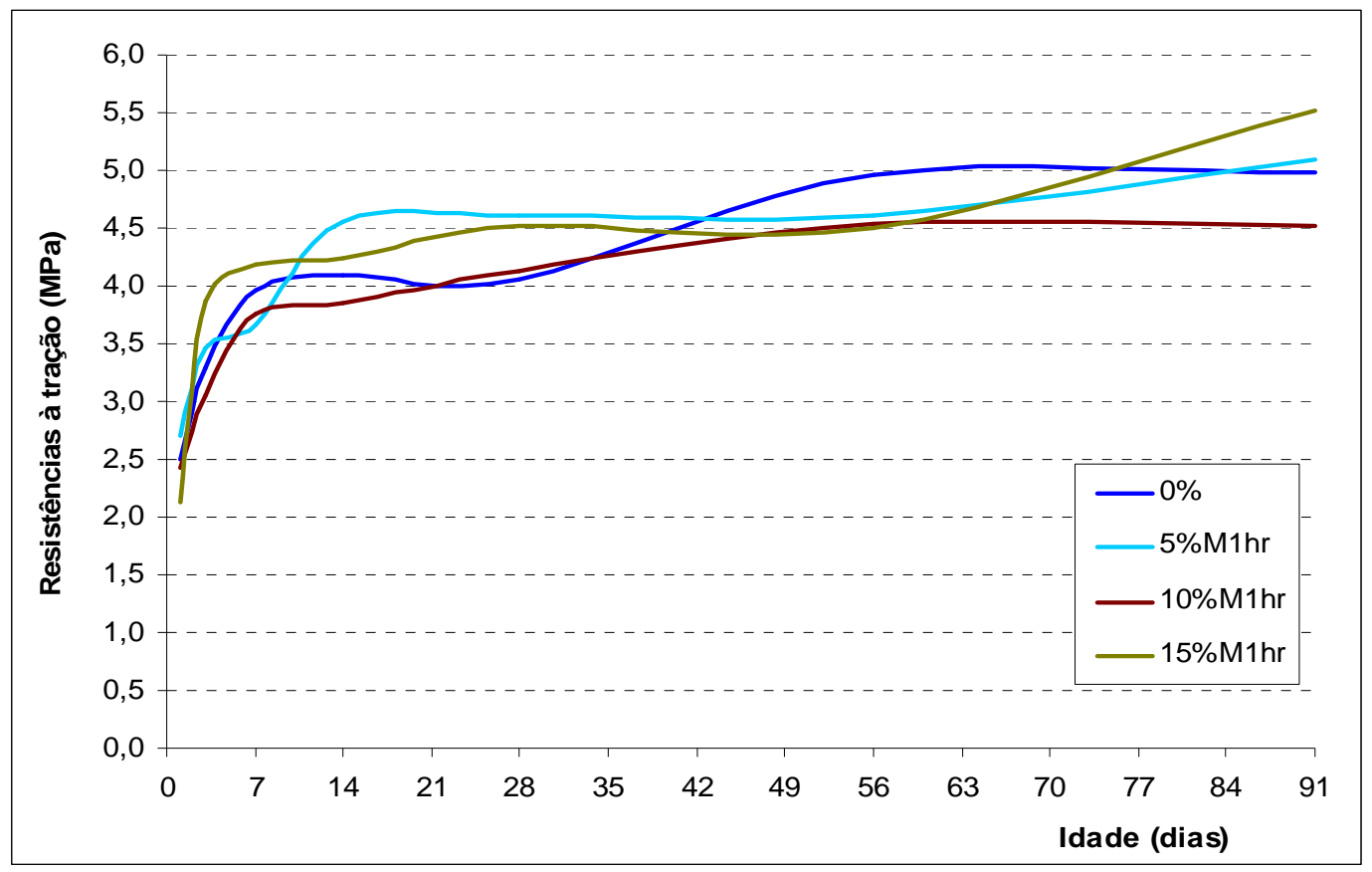

Figura 72: Gráfico de resistência à tração de argamassas com CCA moída por 1h.

O comportamento à tração foi similar ao à compressão, com os melhores resultados para as argamassas com 15\% de adição de CCA. O desenvolvimento da resistência foi mais significativo até a segunda semana de idade com tendência a estabilização no período seguinte. Somente as misturas com fração de $15 \%$ de CCA obtiveram a curva com tendência ao crescimento após os 91 dias.

Assim como com a resistência à compressão, as argamassas com 10\% de CCA obtiveram, em geral, resultados piores às demais.

A porcentagem da resistência à tração em relação à compressão apresentou crescimento com o aumento da fração de CCA. Para as misturas sem a cinza e com $5 \%$ de CCA, a resistência à tração foi aproximadamente $7,5 \%$ da à compressão, para a com $10 \%$ de CCA foi de $8 \%$ e para a com $15 \%$ de CCA foi de $9 \%$. 


\subsection{ENSAIOS EM CONCRETOS COM ADIÇÃO DE CCA}

\subsubsection{Resistência à compressão}

O ensaio de resistência à compressão foi realizado com corpos-de-prova cilíndricos de $10 \times 20 \mathrm{~cm}$ de concreto saturados com a superfície seca, conforme NBR 5739:1994. As idades ensaiadas foram: 3, 7, 28 e 60 dias.

As tabelas com os resultados dos ensaios de resistência à compressão estão apresentados no Anexo $\mathrm{B}$ e os diagrama resistência à compressão $\mathrm{x}$ idade estão apresentados na Figura 73.

As linhas traço-ponto da Figura 73 representam os concretos sem adição de CCA e as linhas contínuas os com adição de 15\% de CCA.

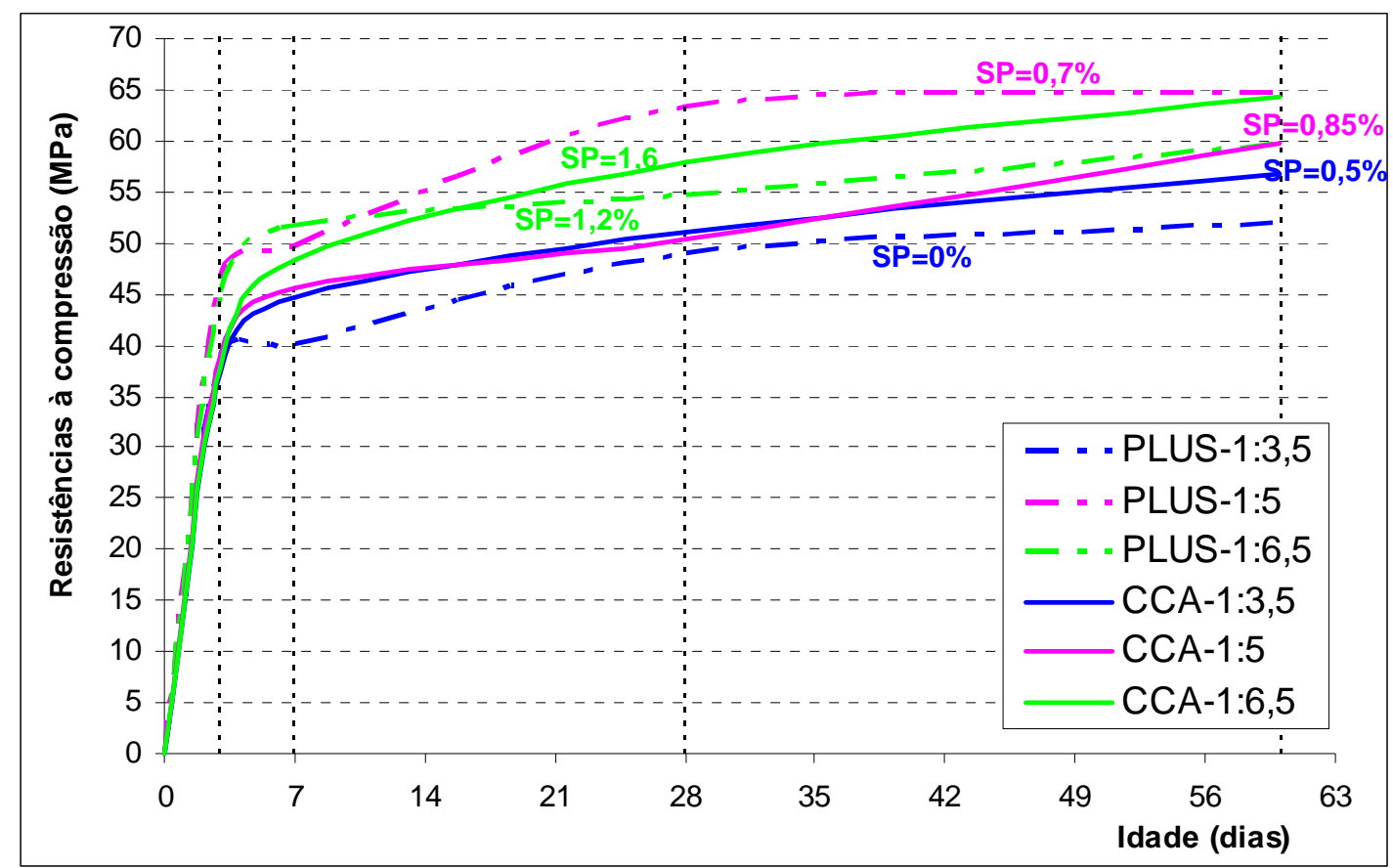

Figura 73: Gráfico de resistência à compressão x idade dos concretos.

Observa-se que as algumas misturas apresentam um comportamento adverso do ponto de vista do consumo de cimento. Nem todas as misturas mais ricas 
em cimento atingiram resistências superiores às mais pobres. Esta situação se deve à variação na quantidade de superplastificante na composição das misturas. $\mathrm{O}$ teor de superplastificante no traço rico $(1: 3,5)$ foi demasiadamente pequeno para o concreto com CCA e igual a zero para o sem adição, prejudicando a dispersão das partículas finas e, conseqüentemente, dificultando a hidratação do cimento. Nos casos em que este comportamento invertido ocorreu, o efeito do aumento do consumo de cimento na resistência à compressão foi menos significativo que o efeito do superplastificante na mistura. O mesmo ocorre com um superplastificante policarboxílico, como o utilizado neste trabalho, conforme está ilustrado na Figura 74. Observa-se na figura que é possível um aumento de $52 \%$ na resistência à compressão do concreto com adição de superplastificante do tipo policarboxílico em relação ao concreto equivalente sem o aditivo, ou seja, sem aumentar o consumo de cimento.

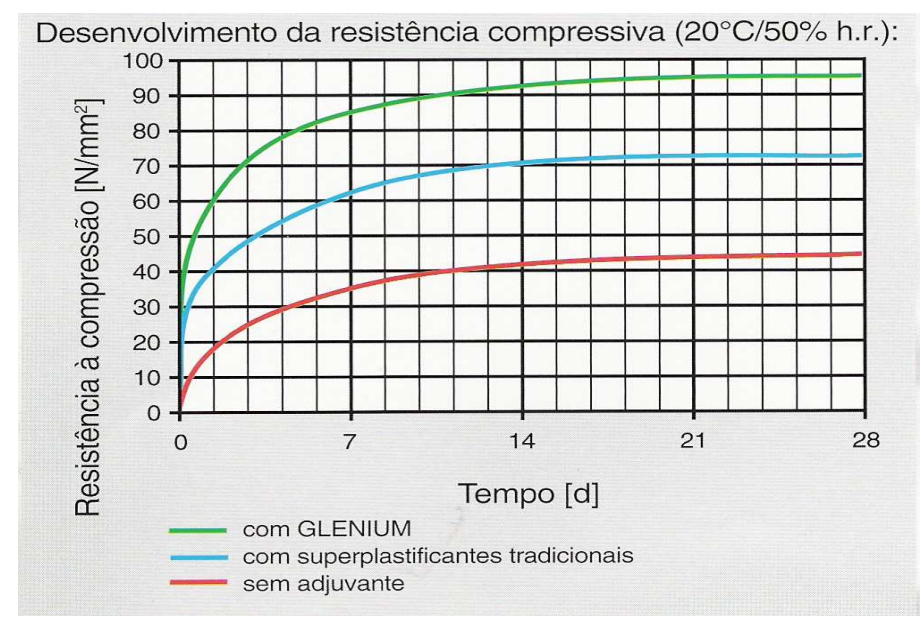

Figura 74: Resistência à compressão x idade em concretos com e sem aditivo superplastificante. Fonte: Catálogo do superplastificante Glenium da Master Builders Technologies.

A Figura 73 demonstra que o concreto com CCA pode trazer vantagens em relação à resistência à compressão dependendo da dosagem. Comparando-se as misturas com traço 1:6,5, nas quais foi utilizado superplastificante, percebe-se que os valores são próximos. 
$\mathrm{Na}$ mistura rica $(1: 3,5)$ percebe-se uma melhoria na resistência no concreto com a adição da cinza, mas como não houve adição de superplastificante na mistura sem CCA, não é possível uma conclusão se a causa desta melhoria foi a CCA ou 0 aditivo.

Para os concretos com traço normal (1:5), a mistura com adição de CCA obteve resistência inferior à mistura sem adição. Neste caso, ambos os concretos tinham aditivo superplastificante em suas misturas. Este comportamento pode significar que o teor de superplastificante na mistura com CCA $(\mathrm{SP}=0,85 \%)$ não foi suficiente para provocar a mesma melhoria na dispersão que na mistura sem adição (SP=0,7\%). Neste momento, cabe lembrar que a substituição do cimento CPV-ARI PLUS por cinza da casca de arroz foi em massa, o que traz como conseqüência um aumento de partículas aglomerantes para um mesmo volume devido à massa específica da CCA ser menor que a do cimento.

Em relação ao desenvolvimento da resistência à compressão, é na primeira semana que aumento é mais significativo. Após este período, o crescimento continua, mas de forma mais lenta. As curvas de todas as misturas com CCA se apresentaram com tendência ascendente depois dos 60 dias, o que demonstra que as resistências à compressão aumentarão ainda mais. Para estes concretos, houve aumento em média de $13,5 \%$ na resistência no período entre os 28 e os 60 dias. Já nas misturas sem a adição de CCA, este aumento foi em média de 5,7\% e após os 60 dias as curvas demonstram uma tendência à estabilização.

A resistência à compressão aos 28 dias dos concretos com CCA foi igual ou superior a 50,4MPa, o que significa que todos os traços resultaram em concretos de alta resistência, ressaltando que eles contêm adição de CCA, o que o torna ecologicamente correto. 
Comparando-se o resultado aos 28 dias do concreto de traço $1: 6,5,15 \%$ de CCA, teor de superplastificante de 1,6\% e com relação água-aglomerante igual a 0,465 com o obtido por Lima (2006) a partir de um concreto de mesmo traço, confeccionado no LMABC com agregados advindos do mesmo lote que os utilizados nesse estudo, $0,5 \%$ de teor do mesmo superplastificante, $10 \%$ de sílica de ferro silício (SFS), consumo de cimento CPII $32 \mathrm{E}$ igual a $303 \mathrm{~kg} / \mathrm{m}^{3}$ e relação água-aglomerante igual a 0,47 , o concreto com CCA foi $38 \%$ mais resistente. A resistência do concreto com SFS foi de 36MPa e a do concreto com CCA foi igual 58MPa.

A ruptura dos corpos-de-prova de concreto se deu com ruptura do tipo cônica (NBR 5739:1994), como mostra a Figura 75.

Figura 75: Forma de ruptura cônica dos CP de concreto.

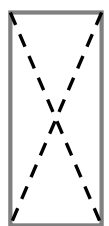

Tabela 38: Consumo de cimento/1MPa de resistência.

\begin{tabular}{|c|c|c|c|}
\hline TRAÇO & CONCRETO & $\begin{array}{l}\text { CONSUMO DE CIMENTO } \\
\text { PARA PRODUZIR 1MPa }\end{array}$ & EFICIÊNCIA DA CCA \\
\hline $1: 6,5$ & $\begin{array}{l}\text { CONCRETO SEM CCA } \\
\text { CONCRETO COM 15\% DE CCA }\end{array}$ & $\begin{array}{l}5,8 \mathrm{~kg} / \mathrm{MPa} \\
4,6 \mathrm{~kg} / \mathrm{MPa}\end{array}$ & $+20,7 \%$ \\
\hline $1: 5$ & $\begin{array}{l}\text { CONCRETO SEM CCA } \\
\text { CONCRETO COM 15\% DE CCA }\end{array}$ & $\begin{array}{l}6,1 \mathrm{~kg} / \mathrm{MPa} \\
6,5 \mathrm{~kg} / \mathrm{MPa}\end{array}$ & $-6,6 \%$ \\
\hline $1: 3,5$ & $\begin{array}{l}\text { CONCRETO SEM CCA } \\
\text { CONCRETO COM 15\% DE CCA }\end{array}$ & $\begin{array}{l}10,0 \mathrm{~kg} / \mathrm{MPa} \\
8,1 \mathrm{~kg} / \mathrm{MPa}\end{array}$ & $+19,0 \%$ \\
\hline
\end{tabular}

É importante salientar os benefícios econômicos que a cinza da casca de arroz pode propiciar ao concreto. A Tabela 38 mostra o consumo de cimento necessário para se produzir $1 \mathrm{MPa}$ de resistência à compressão aos 28 dias. Para os concretos rico e pobre, com a adição da CCA, foi possível reduzir em torno de $20 \%$ este consumo. Também é importante notar que foi possível produzir um concreto com resistência de 58MPa aos 28 dias com um consumo de cimento de $269 \mathrm{~kg} / \mathrm{m}^{3}$. 
Tabela 39: Temperatura x consumo de cimento.

Fonte: Andriolo (2001).

\begin{tabular}{|c|c|c|c|c|c|c|c|}
\hline \multirow{2}{*}{$\begin{array}{c}\text { Altura das } \\
\text { Camadas (m) }\end{array}$} & \multirow{2}{*}{$\begin{array}{l}\text { Intervalo de } \\
\text { colocação } \\
\text { (dias) }\end{array}$} & \multirow{2}{*}{$\begin{array}{l}\text { Temperatura de } \\
\text { Colocação }\left({ }^{\circ} \mathrm{C}\right)\end{array}$} & \multicolumn{5}{|c|}{$\begin{array}{c}\text { Temperaturas máximas nas estruturas para } \\
\text { concretos com consumos de }\left(\mathrm{Kg} / \mathrm{m}^{3}\right)\end{array}$} \\
\hline & & & 75 & 125 & 175 & 275 & 300 \\
\hline & & 20 & 28,2 & 30,6 & 32,9 & 38,4 & 39,5 \\
\hline & & 25 & 29,7 & 32,0 & 34,4 & 39,8 & 41,0 \\
\hline \multirow[t]{5}{*}{0,5} & 3 & 30 & 31,2 & 33,5 & 35,8 & 41,3 & 42,5 \\
\hline & & 35 & 33,3 & 35,2 & 37,5 & 42,7 & 43,9 \\
\hline & & 40 & 36,4 & 37,5 & 39,4 & 44,4 & 45,5 \\
\hline & & 20 & 29,0 & 32,7 & 36,5 & 44,6 & 46,5 \\
\hline & & 25 & 31,5 & 35,3 & 39,1 & 47,2 & 49,1 \\
\hline \multirow[t]{5}{*}{1} & 3 & 30 & 34,1 & 37,9 & 41,7 & 49,8 & 51,7 \\
\hline & & 35 & 37,1 & 40,5 & 44,3 & 52,4 & 54,3 \\
\hline & & 40 & 40,4 & 43,8 & 47,1 & 55,0 & 56,9 \\
\hline & & 20 & 29,1 & 33,5 & 37,9 & 47,2 & 49,4 \\
\hline & & 25 & 32,2 & 36,7 & 41,1 & 50,3 & 52,5 \\
\hline \multirow[t]{5}{*}{1,5} & 3 & 30 & 35,3 & 39,9 & 44,3 & 53,5 & 55,7 \\
\hline & & 35 & 39,0 & 43,3 & 47,6 & 56,7 & 58,9 \\
\hline & & 40 & 43,1 & 46,8 & 51,1 & 60,1 & 62,2 \\
\hline & & 20 & 29,1 & 33,9 & 38,6 & 48,6 & 51,0 \\
\hline & & 25 & 32,7 & 37,5 & 42,3 & 52,3 & 54,7 \\
\hline \multirow[t]{5}{*}{2} & 3 & 30 & 36,4 & 41,2 & 46,0 & 56,0 & 58,4 \\
\hline & & 35 & 40,4 & 45,0 & 49,7 & 59,7 & 62,1 \\
\hline & & 40 & 44,5 & 49,1 & 53,7 & 63,4 & 64,8 \\
\hline & & 20 & 29,1 & 34,1 & 39,1 & 49,4 & 51,9 \\
\hline & & 25 & 32,9 & 38,0 & 43,1 & 53,4 & 55,9 \\
\hline \multirow[t]{5}{*}{2,5} & 3 & 30 & 36,9 & 42,0 & 47,1 & 57,4 & 60,0 \\
\hline & & 35 & 41,2 & 46,0 & 51,1 & 61,5 & 64,0 \\
\hline & & 40 & 45,6 & 50,4 & 55,2 & 65,5 & 68,0 \\
\hline & & 20 & 29,2 & 34,5 & 39,8 & 50,7 & 53,3 \\
\hline & & 25 & 33,3 & 38,6 & 43,9 & 54,8 & 57,5 \\
\hline \multirow[t]{3}{*}{3} & 3 & 30 & 37,5 & 42,8 & 48,1 & 58,9 & 61,6 \\
\hline & & 35 & 41,8 & 47,1 & 52,4 & 63,2 & 65,9 \\
\hline & & 40 & 46,4 & 51,4 & 56,8 & 67,5 & 70,2 \\
\hline
\end{tabular}

A redução do consumo do cimento, além da vantagem econômica, diminui a dissecação interna e a temperatura do concreto. Andriolo F. R. (2001) mostra os valores de temperatura máximos alcançados na prática em função do consumo de cimento utilizado para uma temperatura ambiente de $26^{\circ} \mathrm{C}$ (Tabela 39 ). A variação entre consumo de cimento e temperatura é quase linear. Extrapolando para o valor de $450 \mathrm{~kg} / \mathrm{m}^{3}$, por exemplo, para uma camada de concreto de $1 \mathrm{~m}$ com temperatura de colocação de $30^{\circ} \mathrm{C}$, a temperatura da estrutura será em torno de $63^{\circ} \mathrm{C}$, ou seja, $11,7^{\circ} \mathrm{C}$ a mais que um concreto com $300 \mathrm{~kg} / \mathrm{m}^{3}$ de consumo de cimento. 


\subsubsection{Módulo de elasticidade}

A partir do ensaio da NBR 8522:1984, determinou-se os módulos de elasticidade secante dos três traços de concreto aos 60 dias, os quais estão apresentados na Tabela 40.

Os módulos de elasticidade tiveram pequena variação entre os traços e estão de acordo com os encontrados em outros trabalhos (SENSALE (2000), MALHOTRA e MEHTA (1996), ZHANG e MALHOTRA (1996).

Tabela 40: Módulo de elasticidade dos concretos.

\begin{tabular}{ccccccc}
\hline \multirow{2}{*}{ TRAÇO } & \multicolumn{3}{c}{ CONCRETO SEM CCA } & \multicolumn{3}{c}{ CONCRETO COM 15\% DE CCA } \\
\cline { 2 - 7 } & $\mathbf{1 : 3 , 5}$ & $\mathbf{1 : 5}$ & $\mathbf{1 : 6 , 5}$ & $\mathbf{1 : 3 , 5}$ & $\mathbf{1 : 5}$ & $\mathbf{1 : 6 , 5}$ \\
\hline $\mathrm{E}_{\mathrm{cs}}(\mathrm{GPa})$ & 33,6 & 43,8 & 41,2 & 33,5 & 39,6 & 45,1 \\
\hline
\end{tabular}

\subsubsection{Resistência à tração por compressão diametral}

Os resultados da resistência à tração por compressão diametral dos concretos aos 28 dias estão expostos na Tabela 41.

Tabela 41: Resistência à tração por compressão diametral dos concretos.

\begin{tabular}{ccccccc}
\hline \multirow{2}{*}{ TRAÇO } & \multicolumn{3}{c}{ CONCRETO SEM CCA } & \multicolumn{3}{c}{ CONCRETO COM 15\% DE CCA } \\
\cline { 2 - 7 } & $\mathbf{1 : 3 , 5}$ & $\mathbf{1 : 5}$ & $\mathbf{1 : 6 , 5}$ & $\mathbf{1 : 3 , 5}$ & $\mathbf{1 : 5}$ & $\mathbf{1 : 6 , 5}$ \\
\hline $\mathbf{f}_{\text {ctk }}(\mathrm{MPa})$ & 3,6 & 4,1 & 4,4 & 3,4 & 4,2 & 4,6 \\
\hline
\end{tabular}

Os resultados mostram que não houve mudança significativa na resistência à tração com a adição de CCA.

A resistência à tração representa em média $7,3 \%$ da resistência à compressão para os concretos sem adição de CCA e $7,8 \%$ para os concretos com adição de CCA. 


\subsection{ENSAIOS MICROSCÓPICOS}

Depois de preparadas as amostras fraturadas de concreto no traço 1:5 e relação água-aglomerante igual a 0,45 com idades de 1,3, 7, 28, 60 e 90 dias, foram realizados ensaios no laboratório do Instituto de Química de São Carlos (IQSC) da USP.

As Figuras de 76 a 79 são de amostras com 1 dia de idade.

A Figura 76 traz uma imagem de grandes placas de hidróxido de cálcio, segundo análise dos resultados do EDS, nas proximidades do poro, permitindo perceber a morfologia deste produto.

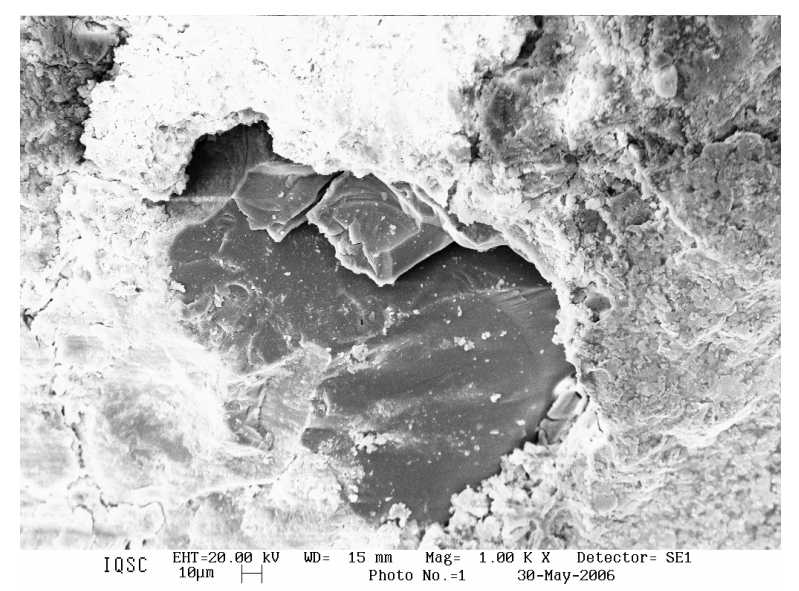

Figura 76: MEV -1 dia de idade (1000X): $\mathrm{CH}$ próximo a um poro.

Na Figura 77 observa-se o aspecto geral da zona de transição numa região em que ocorreu destacamento do agregado. Pelo estudo com EDS, ocorre nesta região a presença de muitos vazios e exclusivamente hidróxido de cálcio, o que demonstra que a ZT ainda é a região fraca do concreto. Também é possível notar que há grande quantidade de vazios na ZT. 


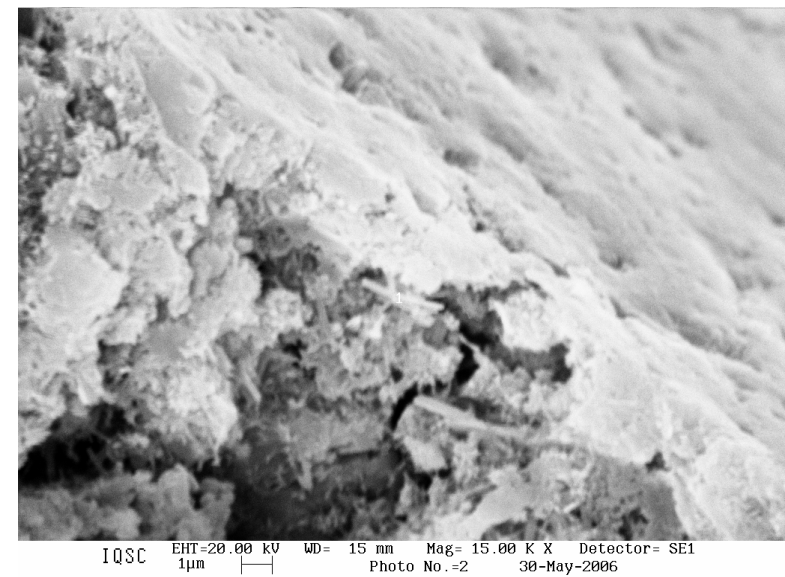

Figura 77: MEV -1 dia de idade (15000X): aspecto geral ZT.

Na Figura 78 percebe-se que a porosidade da matriz da pasta ainda é bastante acentuada e com predominância de $\mathrm{CH}$, mas o EDS do ponto 1 mostrou que a porcentagem de sílica é superior a registrada na zona de transição.

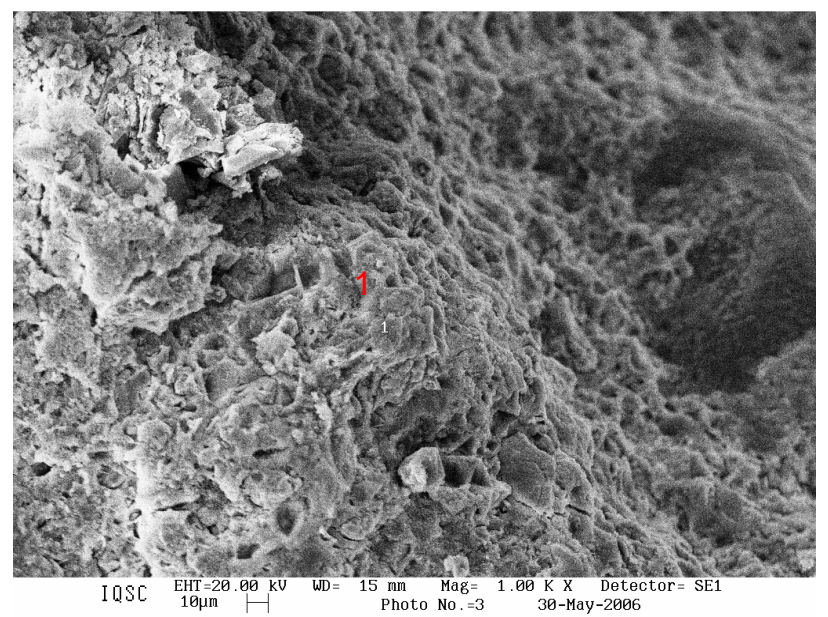

Figura 78: MEV -1 dia de idade (1000X): aspecto geral matriz da pasta.

Na Figura 79a observa-se a imagem das proximidades de um poro no concreto. A Figura 79b, que é a região assinalada em 79a ampliada, juntamente com o EDS e análise da relação $\mathrm{Ca} / \mathrm{Si}$, mostra cristais de hidróxido de cálcio e agulhas de etringita com 24 horas de idade. 


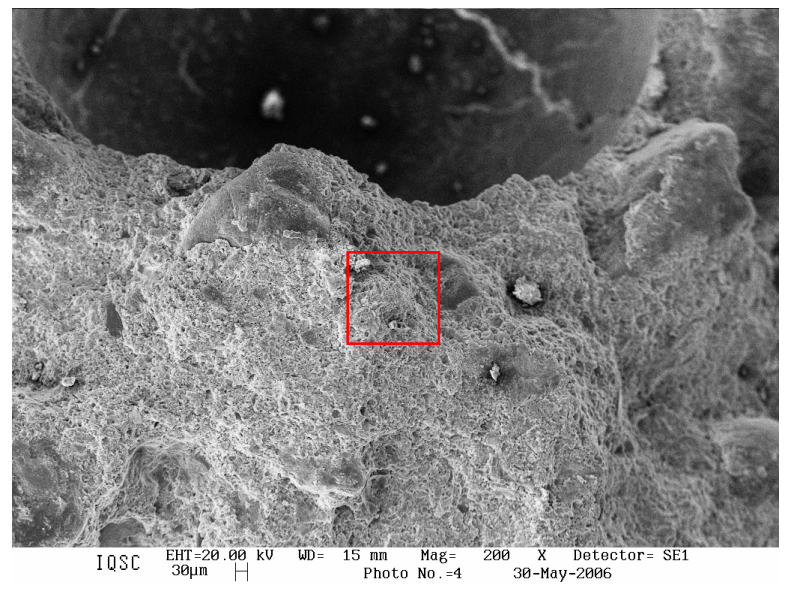

(a)

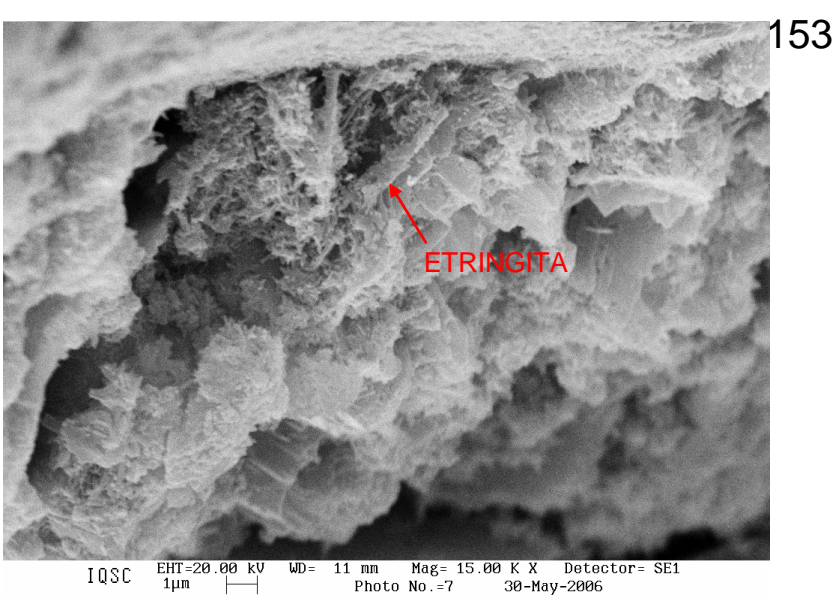

(b)

Figura 79: MEV -1 dia de idade: $\mathrm{CH}$ próximo a um poro; (a) 200X, (b) 15000X.

As Figuras de 80 a 83 são de amostras com 3 dias de idade.

$\mathrm{Na}$ Figura 80 ainda é grande a presença de $\mathrm{CH}$ na matriz da pasta, mas observa-se um aumento na quantidade de etringita. Do aspecto geral da imagem, percebe-se que a matriz da pasta já está bastante mais densa que com 1 dia de idade.

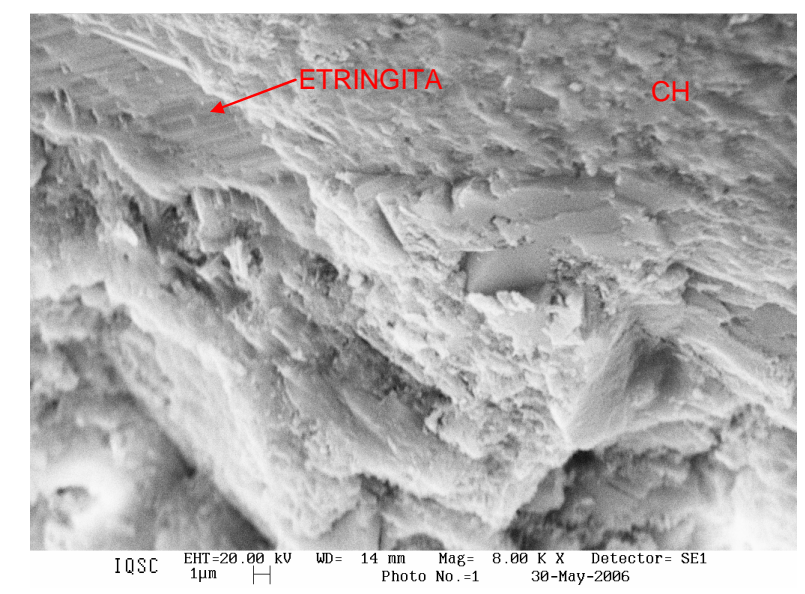

Figura 80: MEV - 3 dias de idade (8000X): aspecto geral matriz da pasta.

Na Figura 81, que mostra a matriz da pasta, há a presença de C-S-H nos pontos 1, 2 e 3, nos quais foram realizadas análises por EDS. Nos pontos 1 e 3, a formação de C-S-H está ocorrendo sobre placas de hidróxido de cálcio. No ponto 2, o C-S-H está formada entre dois pontos de nucleação, formando uma ponte entre os dois 
produtos iniciais e, conseqüentemente, densificando a estrutura da matriz. A Figura 81 mostra ainda a presença de etringita, conforme indicado.

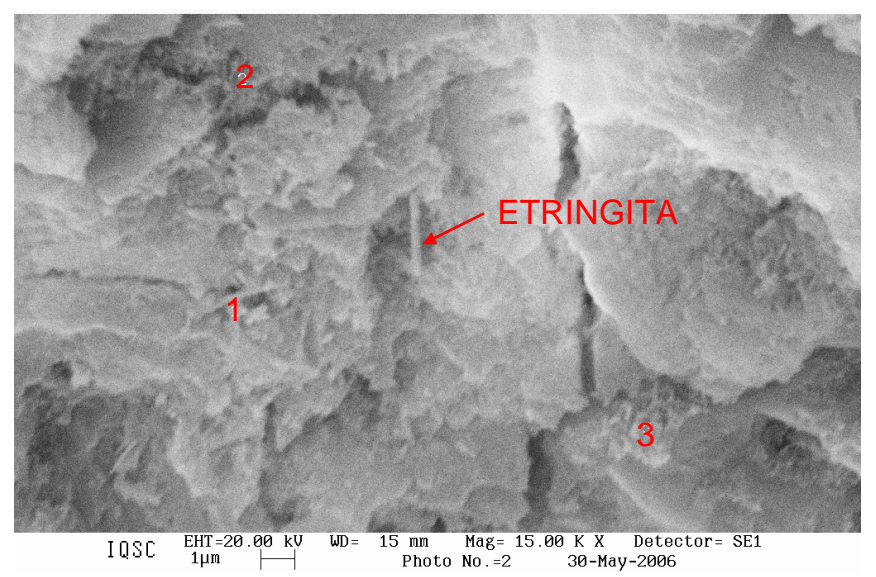

Figura 81: MEV - 3 dias de idade (15000X): C-S-H na matriz da pasta.

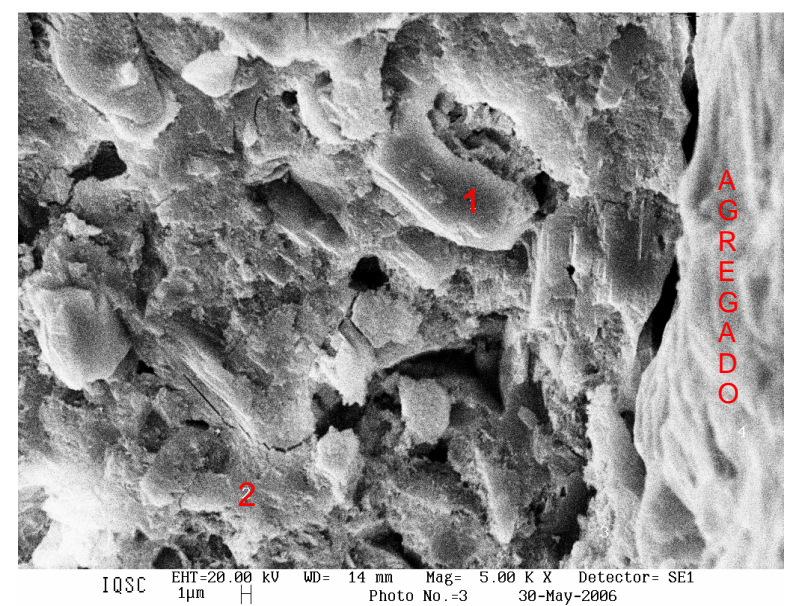

Figura 82: MEV - 3 dias de idade (5000X): ZT.

A zona de transição na Figura 82 apresenta aspecto bastante distinto da matriz da pasta, com produtos maiores, maior presença de hidróxido de cálcio e de vazios. A imagem está de acordo com a teoria de Scrivener (1989) que diz que o tamanho dos vazios decresce com o aumento da distância do agregado. Pela análise dos resultados do EDS, o ponto 1 indica uma placa de $\mathrm{CH}$, já o ponto 2, um cristal de C-S-H. 


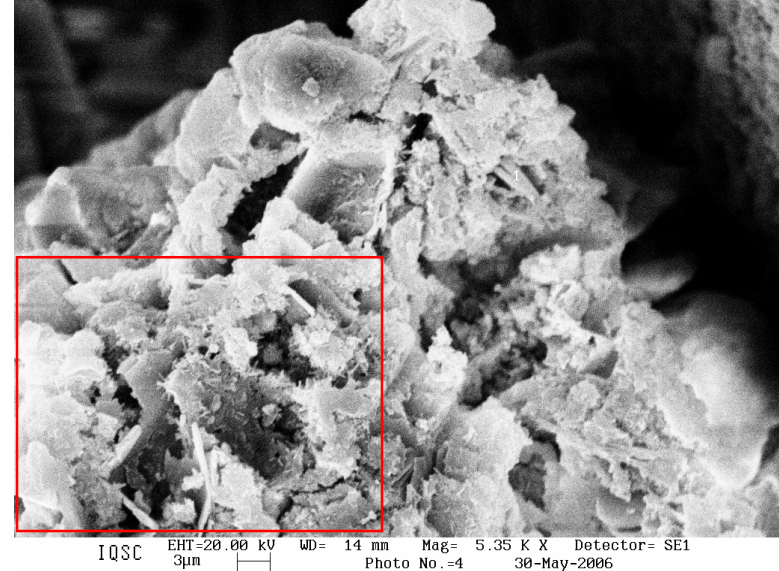

(a)

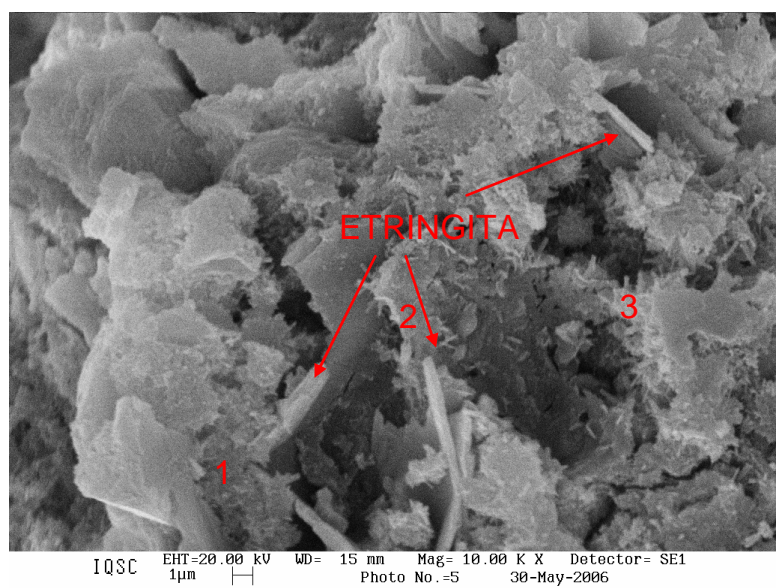

(b)

Figura 83: MEV -3 dias de idade: etringita; (a) 5350X, (b) 10000X.

As Figuras 83a e 83b mostram a densificação da pasta com formação de etringita, sendo que a Figura 83b é a ampliação da região indicada em 83a. Na Figura 83b percebe-se a transformação do hidróxido de cálcio em silicato de cálcio hidratado, pois no ponto 1 o produto encontrado pelo EDS é o $\mathrm{CH}$, já nos pontos 2 e 3, C-S-H.

As Figuras de 84 a 86 são de amostras com 7 dias de idade.

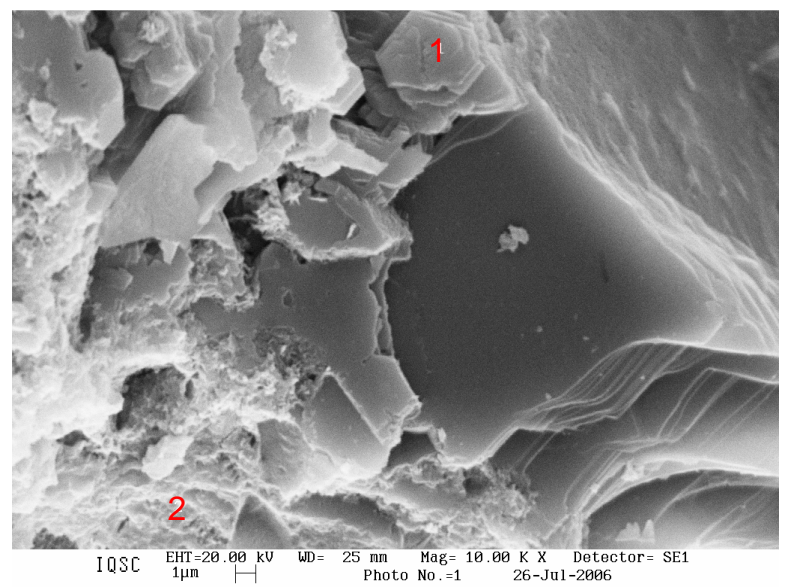

Figura 84: MEV - 7 dias de idade (10000X): CH na ZT.

A Figura 84 mostra uma região onde ocorreu destacamento de agregado (canto superior direito), portanto trata-se da zona de transição. Tanto o ponto 1 como o 
2, indicam presença de $\mathrm{CH}$. Percebe-se que os vazios da região diminuíram em quantidade e tamanho em comparação aos da amostra da Figura 82, que tem 3 dias de idade. Mesmo assim, ainda há grande presença de $\mathrm{CH}$, o que tornou a região fraca e propiciou que a fissuração ocorresse na ZT com destacamento do agregado.

A Figura 85 é uma imagem da matriz da pasta. Observa-se que a mesma tem aspecto denso, com fragmentos de $\mathrm{CH}$ e presença de etringita.

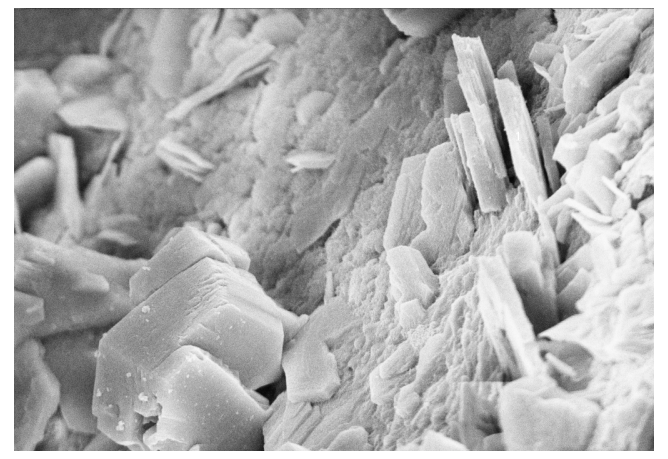

Figura 85: MEV - 7 dias de idade (5000X): $\mathrm{CH}$ e etringita na matriz da pasta.

A Figura 86 mostra o aspecto geral da matriz da pasta aos 7 dias, já bastante densa com vazios pequenos, mas ainda apresentando produtos em processo de reação, como os indicados pelos pontos 1 e 2 . Ambos indicam $\mathrm{CH}$, mas o ponto 2 apresenta porcentagem de sílica mais elevado, o que demonstra que está em processo de transformação em C-S-H.

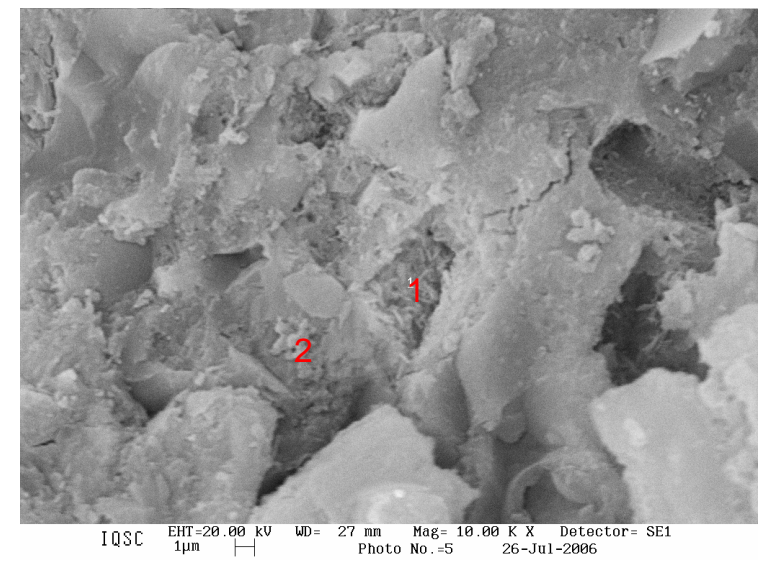

Figura 86: MEV - 7 dias de idade (10000X): aspecto geral da pasta. 
Figuras de 87 a 89 são de amostras com 28 dias de idade.

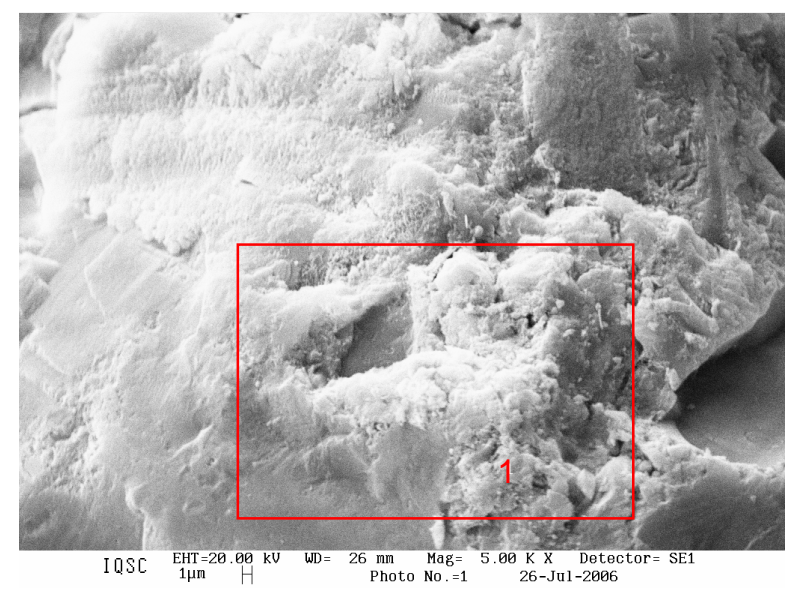

(a)

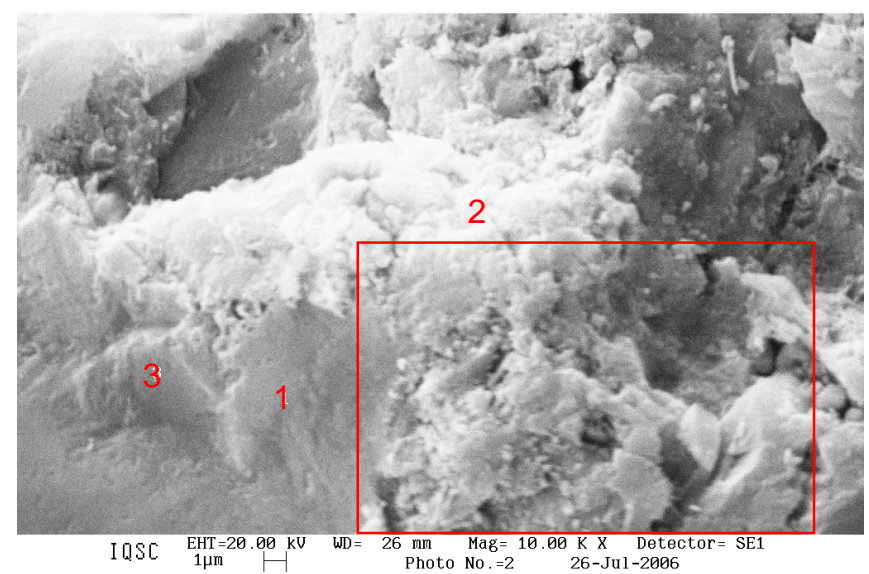

(b)

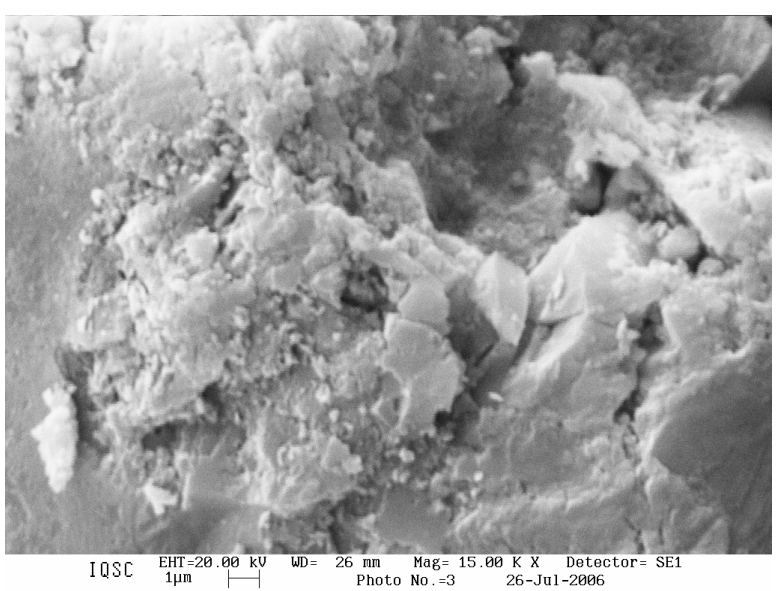

(c)

Figura 87: MEV -28 dias de idade: próximo de agregado; (a) 5000X, (b) 10000X, (c) 15000X.

A Figura 87 traz uma imagem nas proximidades de um agregado. A região assinalada na Figura 87a, corresponde à Figura 87b, e a desta corresponde à Figura 87c. Comparando a Figura 87b com a Figura 86, percebe-se que matriz está muito mais densa que aos 7 dias, apresentando pequenos vazios. Além disso, o C-S-H tornou-se o produto predominante, ele foi detectado no ponto 1 da Figura 87 a e os pontos 1 e 2 da Figura 87b. Na Figura 87c observa-se a morfologia do C-S-H em detalhe. Somente o ponto 3 da Figura 87b corresponde ao hidróxido de cálcio. Em nenhuma imagem foi detectada a presença de etringita por EDS. 


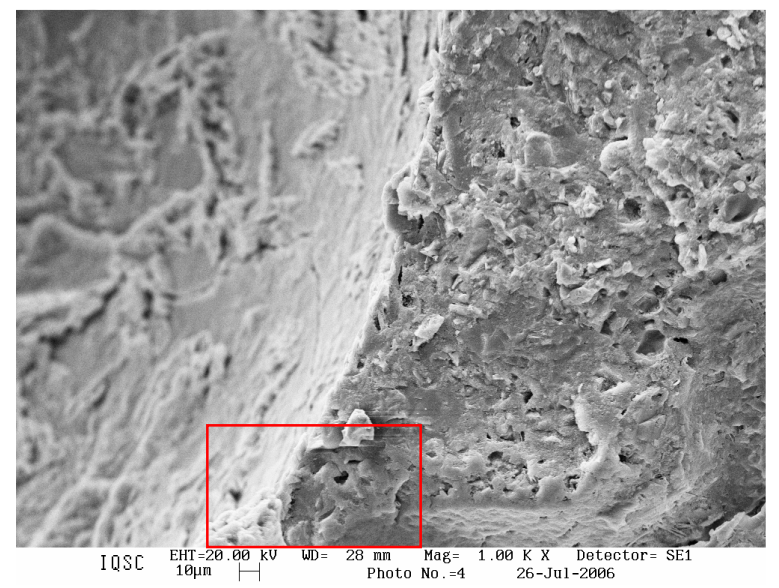

(a)

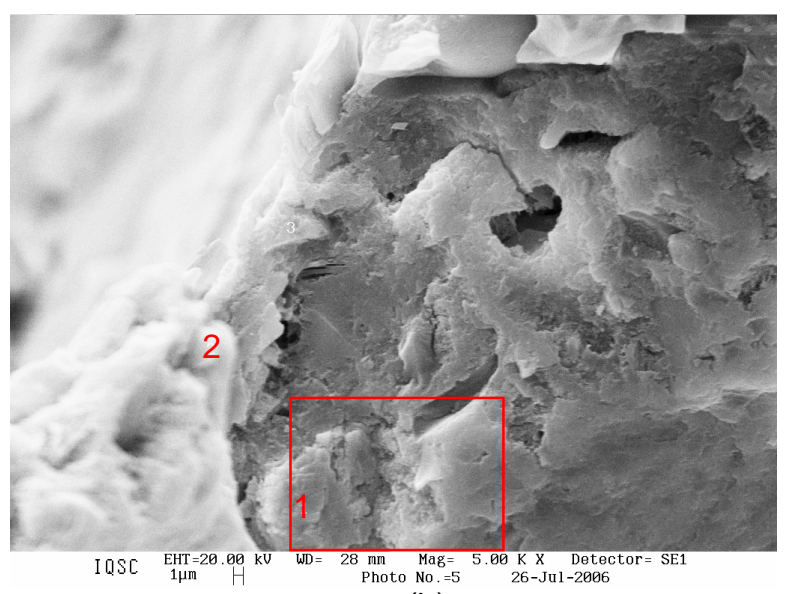

(b)

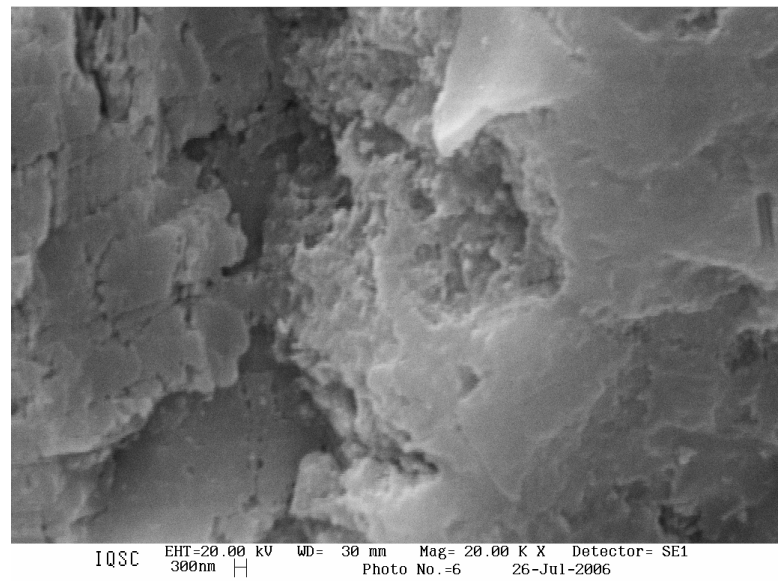

(c)

Figura 88: MEV -28 dias de idade: próximo a um poro; (a) 1000X, (b) 5000X, (c) 20000X.

A Figura 88 contempla a região próxima a um poro. Na Figura 88a observa-se que a matriz da pasta apresenta pequenos vazios, mas de modo geral, ela se encontra bastante densa, como pode ser visto na Figura 88c. Na Figura 88b, pela análise EDS, percebe-se que na região há a presença de C-S-H no ponto 1 (ampliado na Figura 88c) e CH no ponto 2, o qual está mais próximo do poro. 

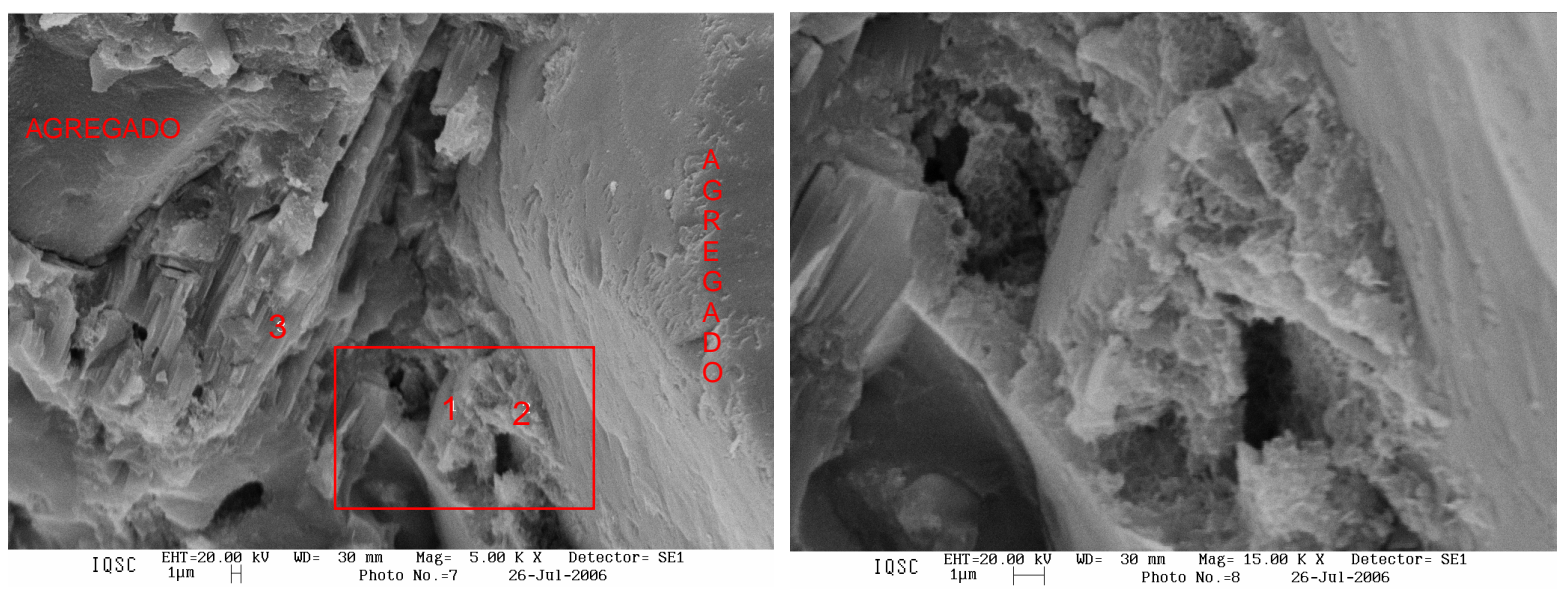

Figura, 89: MEV -28 dias de idade: ZT; (a) 5000X, (b) 1598pX.

A Figura 89a mostra a zona de transição próxima a um agregado com presença de hidróxido de cálcio (pontos 1 e 3) e silicato de cálcio hidratado (ponto 2). No agregado do lado esquerdo da Figura 89a observa-se a morfologia do hidróxido de cálcio com suas placas orientadas perpendicularmente à superfície do agregado. Ampliando a Figura 89a na região indicada, temos a Figura 89b, que mostra uma placa de $\mathrm{CH}$ em processo de transformação em C-S-H. Por esta figura pode-se perceber a morfologia do C-S-H formado a partir do hidróxido de cálcio.

Em nenhuma das amostras de 28 dias foi encontrada etringita, sendo que foram sondados diversos pontos de cada amostra por EDS.

Figuras de 90 a 93 são de amostras com 60 dias de idade.

A Figura 90 contempla a região próxima a um poro. Na Figura 90a observa-se que a matriz da pasta apresenta menos vazios que uma região semelhante com 28 dias de idade (Figura 88a). Isto confirma o aumento de resistência entre 28 e 60 dias constatado pelo ensaio de compressão axial. Na Figura 88b, pela análise EDS, percebe-se que na região há a presença de C-S-H nos ponto 2 e 4 e $\mathrm{CH}$ nos pontos 1 e 3. Ampliando-se a Figura 90b, tem-se a Figura 90c, que mostra como o aumento de 
pontos de nucleação, e a conseqüente diminuição da distância entre as partículas de aglomerante, torna a matriz mais densa.

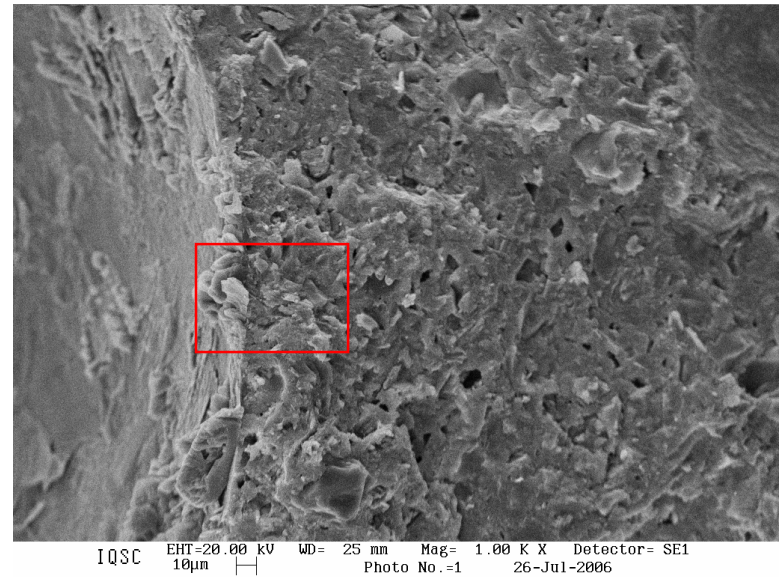

(a)

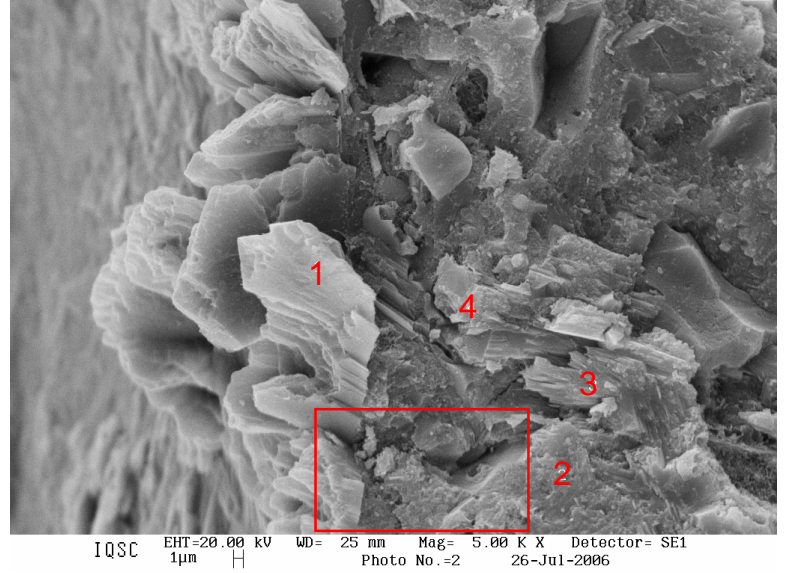

(b)

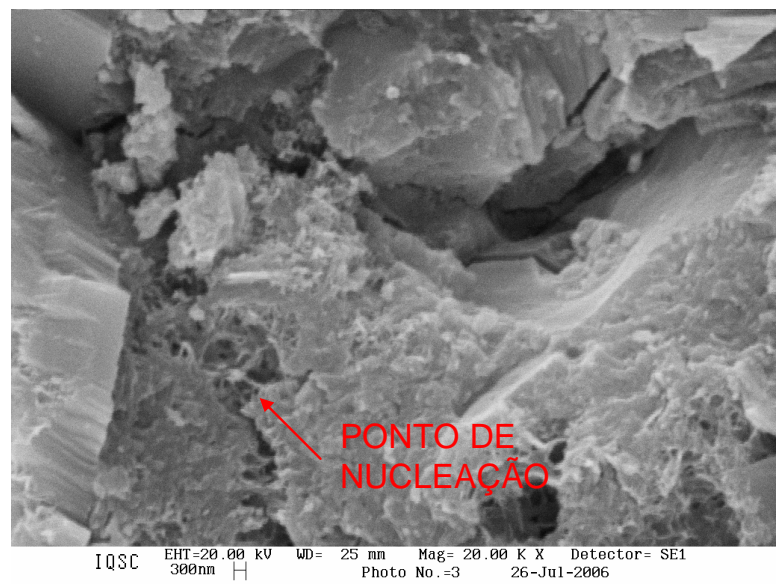

(c)

Figura 90: MEV -60 dias de idade: região próxima a um poro; (a) 1000X, (b) 5000X, (c) 20000X.

$\mathrm{Na}$ Figura 91 observa-se o aspecto geral da matriz da pasta com 60 dias de idade. Comparando-se a Figura 91a com a Figura 86, que mostra a imagem de uma amostra com 7 dias percebe-se a significativa densificação da matriz da pasta e a presença maciça de C-S-H, como por exemplo no ponto 1 . O ponto 3 mostra bastões de etringita e o ponto 2, hidróxido de cálcio. Dentro dos vazios maiores houve formação 
de produtos, tornando-os menores e menos frágeis. A região marcada na Figura 91a é a Figura 91b, que é um bom exemplo deste fato.
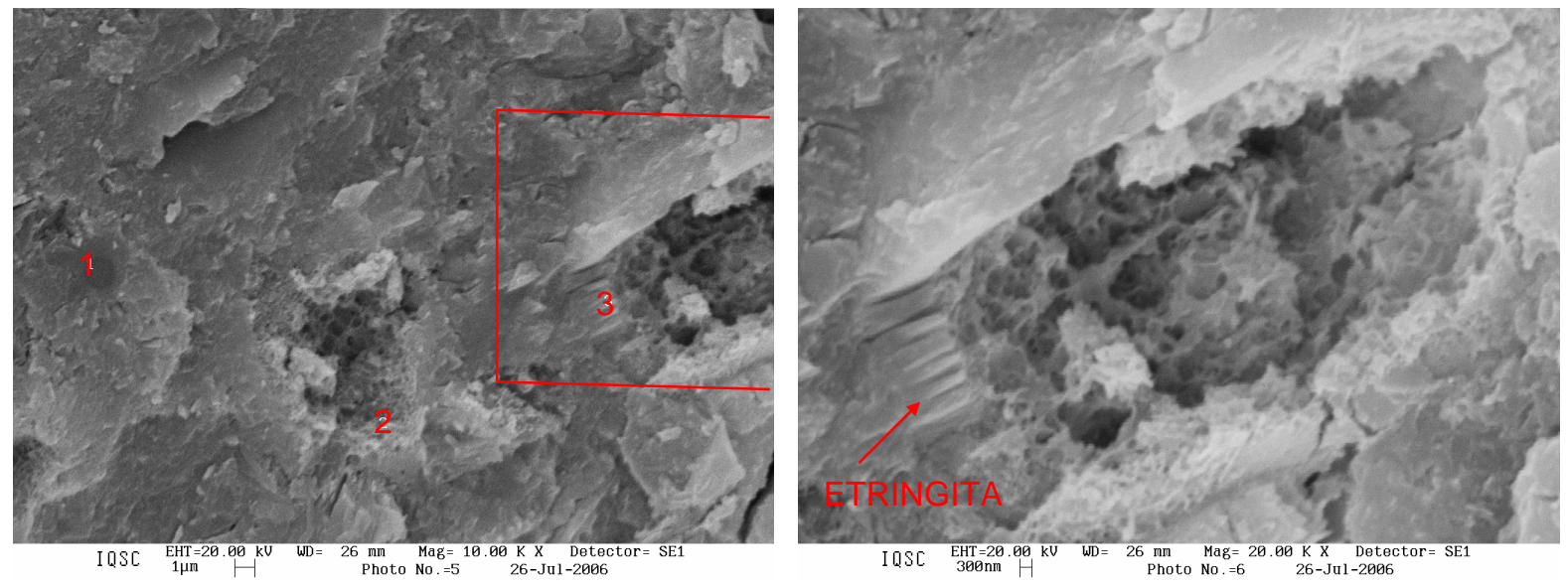

Figura 91: MEV -60 dias de idade: matriz da pasta; (a) 10000X, (b) 20000X.

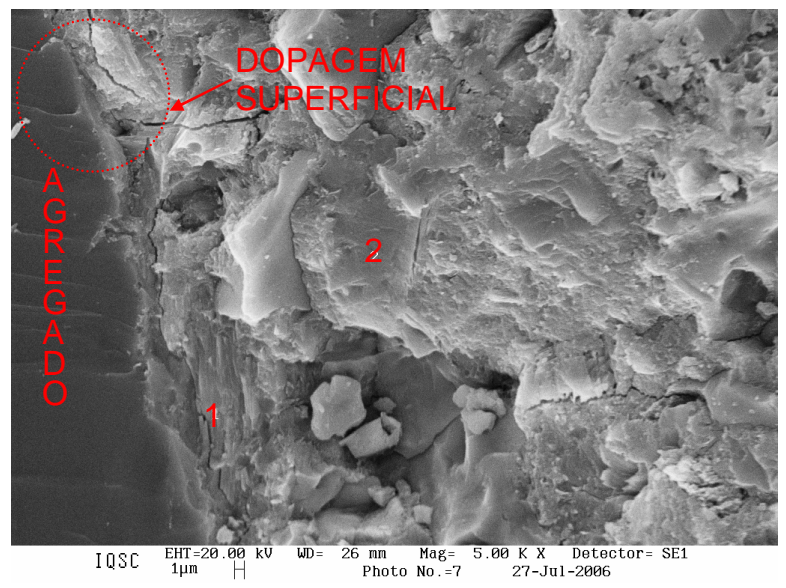

Figura 92: MEV - $5000 \mathrm{X}-60$ dias de idade: ZT.

As Figuras 92 e 93 são de zonas de transição. Em ambas as figuras observa-se uma diferenciação entre as regiões mais e menos próximas do agregado. A região mais afastada é mais densa. Na Figura 92 o ponto 1 representa $\mathrm{CH}$ e o ponto 2 C-S-H. Nesta figura é possível perceber o tratamento de dopagem superficial com a cinza de casca de arroz. A Figura 93a mostra nos pontos 1 e 2 o produto $\mathrm{C}-\mathrm{S}-\mathrm{H}$, e nos pontos 3 e 4, hidróxido de cálcio. As Figuras 92 e 93a comparadas à Figura 89, que apresenta uma imagem da ZT de uma amostra com 28 dias de idade, mostram 0 
desenvolvimento da reação de hidratação e, principalmente da pozolânica, com significativa diminuição do tamanho dos produtos $\mathrm{CH}$. Na Figura 93b observa-se a morfologia do $\mathrm{CH}$ na região da zona de transição.

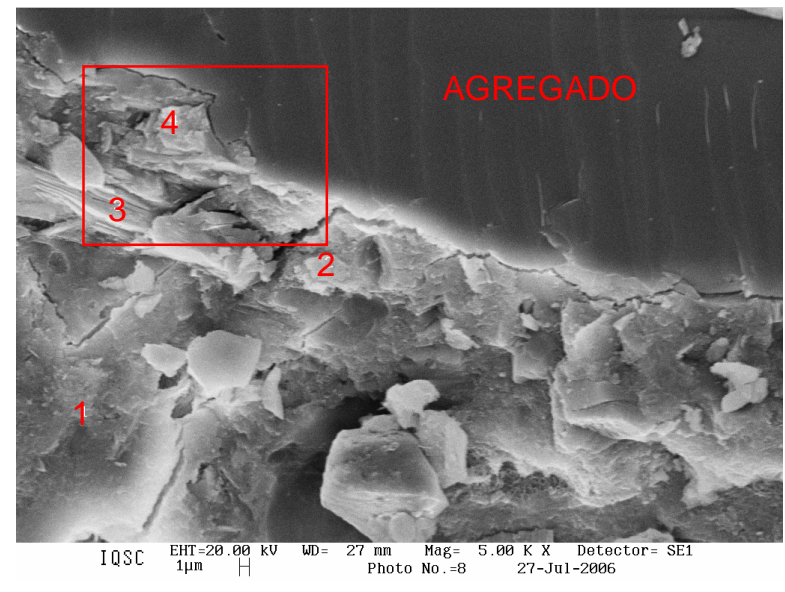

(a)

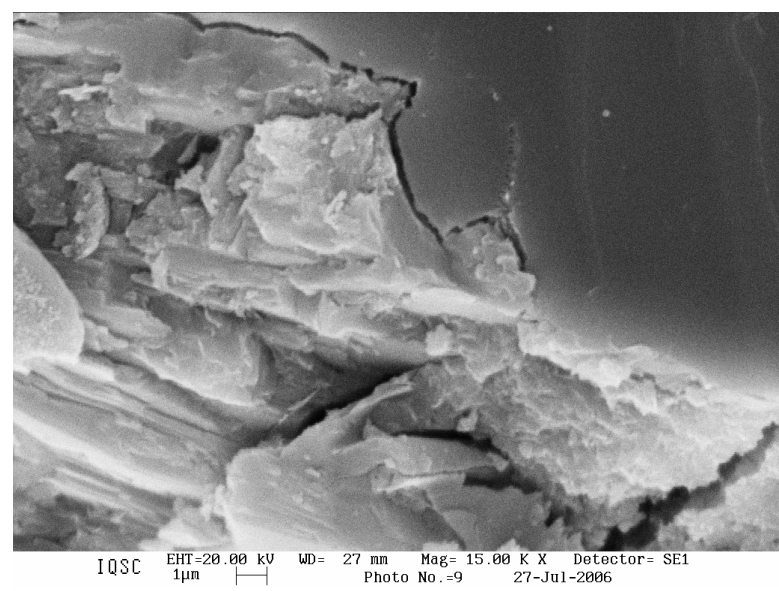

(b)

Figura 93: MEV - 60 dias de idade: ZT; (a) 5000X, (b) 15000X.

As Figuras de 94 à 96 são de amostras com 90 dias de idade.

A Figura 94 mostra imagens de uma região próxima a um poro. Comparando-se com a Figura 90, que trata de uma região semelhante com 60 dias de idade, percebe-se uma redução no tamanho e quantidade de vazios, mas de maneira menos acentuada do que havia ocorrido até a idade de 60 dias. A Figura 94b é a ampliação da região indicada na Figura 94a e mostra que o aspecto geral da pasta é muito similar ao da amostra com 60 dias. Nesta região há grande concentração de hidróxido de cálcio e este com formas diferentes, como observa-se na Figura 94b. Os pontos 1, 2 e 3 indicam a presença de $\mathrm{CH}$ e todos têm morfologias distintas. $\mathrm{O} \mathrm{CH}$ do ponto 1 está ampliado na Figura 94c, ele tem aspecto de uma placa grande hexagonal, morfologia característica do produto oriundo da hidratação do cimento Portland. O ponto 1 da Figura 94c também indica a presença de $\mathrm{CH}$. A Figura 94d é a ampliação da região indicada na Figura 94b e mostra outras formas de hidróxido de cálcio. 


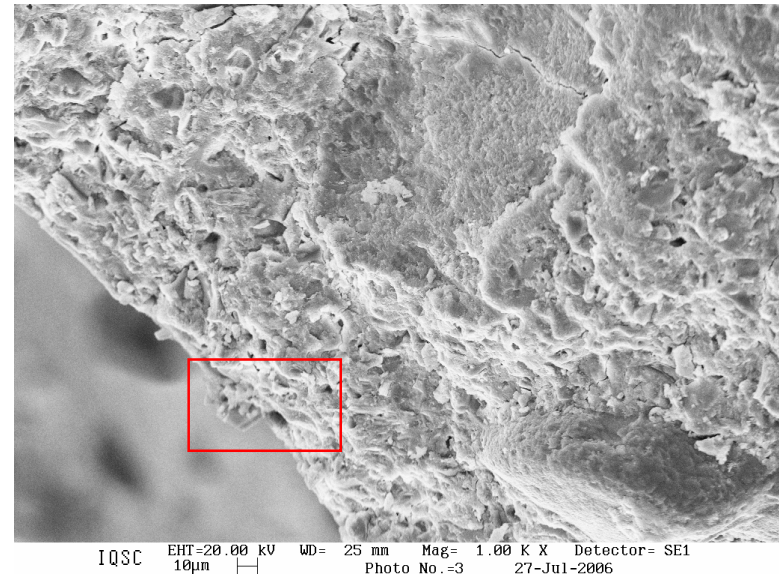

(a)

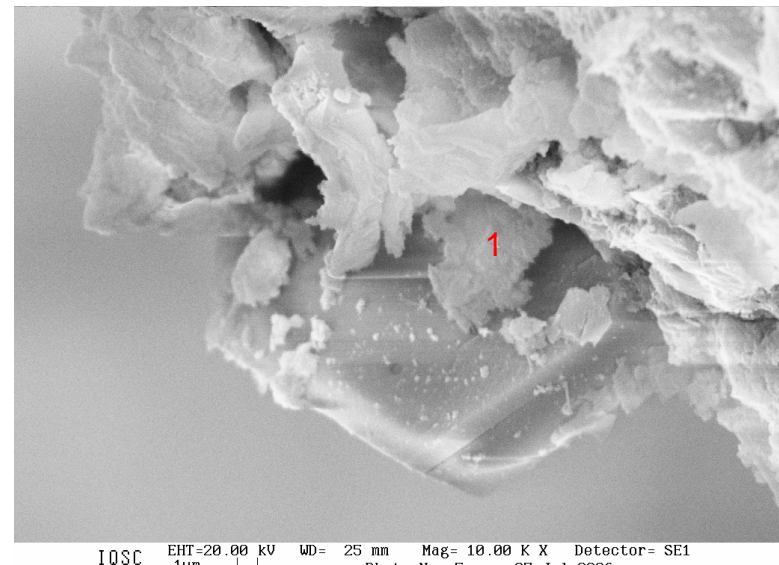

(F)igura 94: MEV - 90 dias de idade: região de um porbẹ)

(a) 1000X, (b) 5000X, (c) 10000X, (d) 15000X.

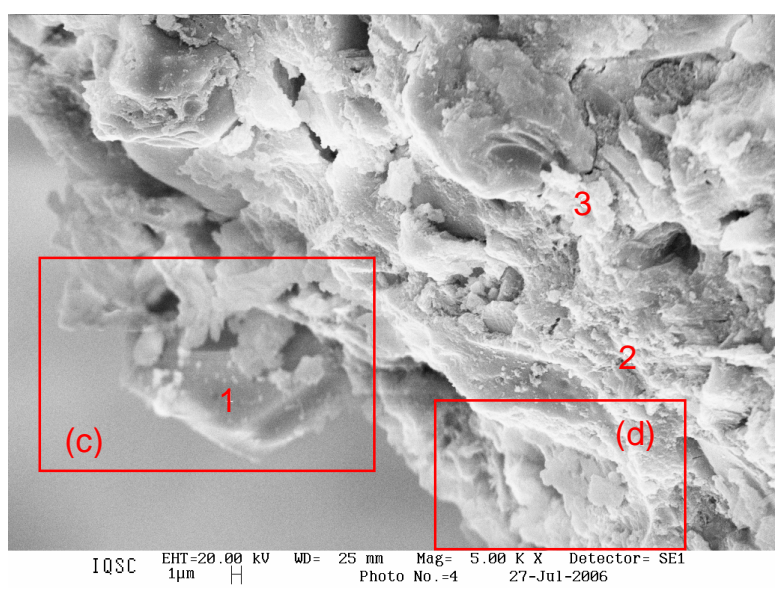

(b)

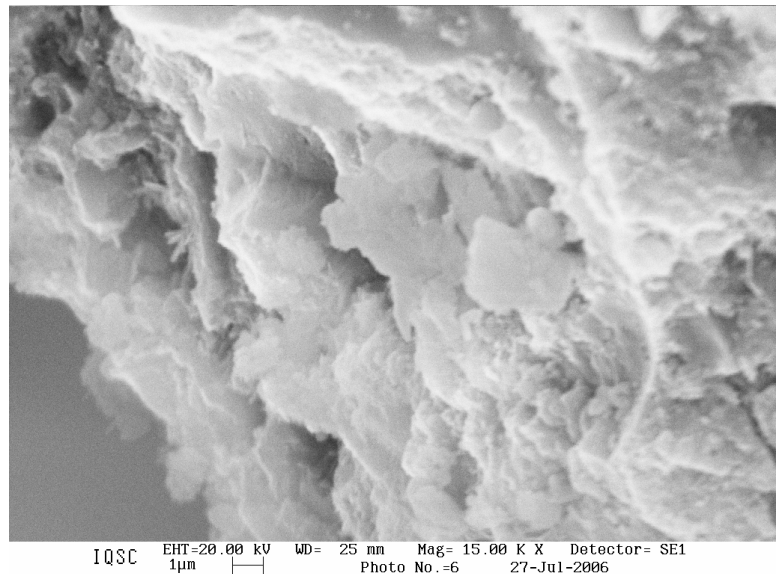


A Figura 95 é da região da zona de transição. Os pontos 1 e 4 da Figura 95a indicam a presença de $\mathrm{CH}$ e os pontos 2 e 5 indicam C-S-H. O produto do ponto 3 , pela análise EDS, é uma sílica, provavelmente um aglomerado de cinza de casca de arroz que não reagiu. Na Figura 95b, tem-se $\mathrm{CH}$ no ponto 1 e C-S-H no ponto 2. Comparando-se coma Figura 93, observa-se que houve uma redução no tamanho dos hidróxidos de cálcio.

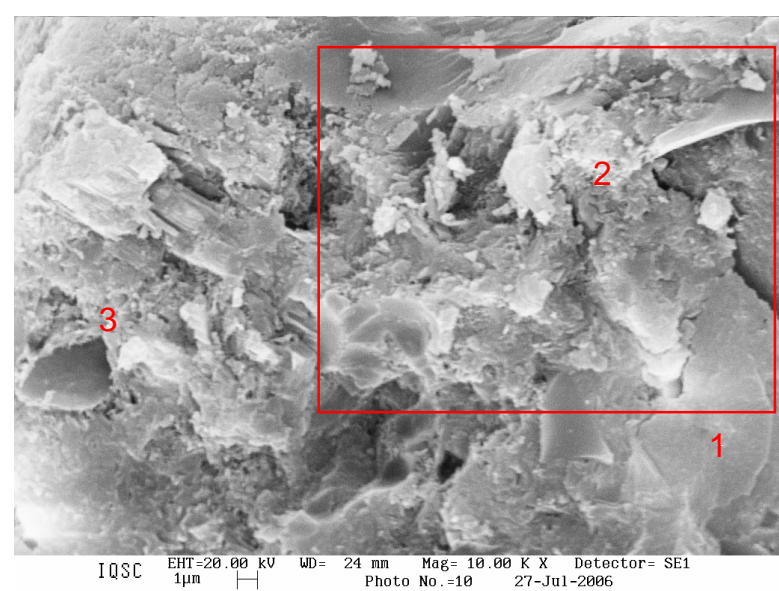

(a)

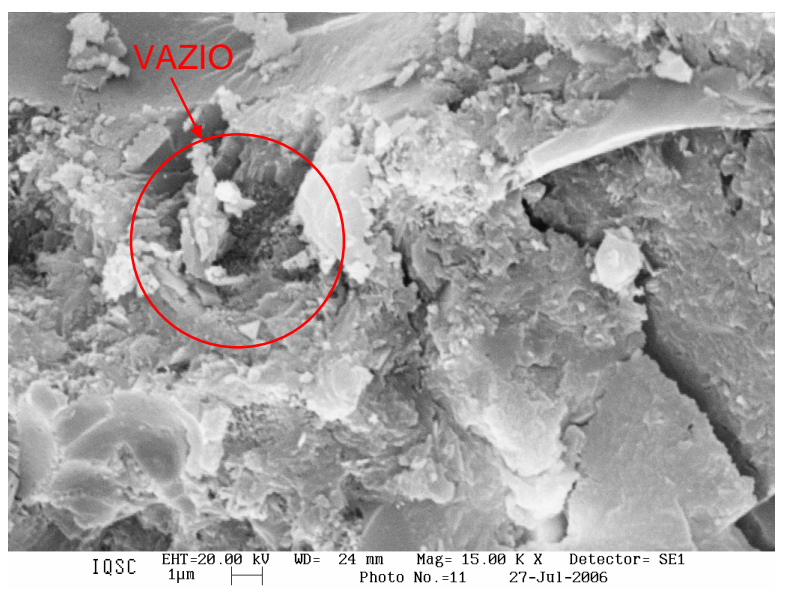

(b)

Figura 96: MEV - 90 dias de idade: matriz da pasta; (a) 10000X, (b) 15000X.

A Figura 96 traz o aspecto geral da pasta com 90 dias de idade. Os pontos 1, 2 e 3 indicam a presença de $\mathrm{CH}$. Na Figura 96b, observa-se que dentro dos vazios há formação de produtos. 


\section{CONCLUSÕES}

Baseado nos resultados dos ensaios, é possível concluir que a cinza da casca de arroz da termoelétrica do Rio Grande do Sul utilizada nesta pesquisa é uma pozolana predominantemente cristalina, altamente reativa possível de ser utilizada como componente em cimentos.

Os aglomerantes compostos pelas misturas de cimento Portland de alta resistência inicial e 5\%, 10\% e 15\% de cinza da casca de arroz em substituição em massa do cimento podem ser classificados como Cimentos Portland Compostos de Alta Resistência Inicial pelas normas brasileiras.

A reatividade com o cimento, analisada a partir do índice de atividade pozolânica, mostrou-se bastante elevada, tanto no ensaio recomendado pela ABNT, como pelo método internacional Chapelle modificado, o que demonstra a grande sinergia entre o cimento Portland e a cinza de casca de arroz.

A composição química da cinza como predominantemente cristalina está de acordo com a temperatura de queima a que foi submetida de aproximadamente $1000^{\circ} \mathrm{C}$

Quanto aos tempos de pega, o efeito da reação pozolânica, que é mais lenta que a hidratação do cimento, foi proporcional a quantidade de adição de CCA que substituiu a de cimento. Para as porcentagens maiores o início e fim de pega foram mais tardios. Houve um atraso significativo das misturas com CCA em relação as sem adição.

Em relação à finura, a moagem adicional de 1 hora em moinho de bolas em laboratório não foi eficiente na melhoria das propriedades das argamassas. 
Provavelmente, o tempo total de moagem a que foi submetida essa cinza ultrapassou o tempo ótimo de moagem citado por Santos (1990). Este tempo deve ser próximo ao utilizado na indústria e que originou em um material com BET de $14,3023 \mathrm{~m}^{2} / \mathrm{g}$.

Nas misturas de argamassa padrão nas primeiras idades, quanto maior é o teor de CCA, menor a resistência à compressão, porém com maior idade o comportamento se inverte, quanto maior a teor de CCA, maior a resistência à compressão. Isto deve acontecer pela diminuição de $\mathrm{C}_{3} \mathrm{~S}$, causada pela substituição do cimento Portland por material pozolânico $(\mathrm{CCA})$ e, como a reação pozolânica é mais lenta, a resistência demora mais para se desenvolver. A resistência à compressão das misturas demonstrou um comportamento ascendente, o que indica que, mesmo após os 90 dias, a resistência à compressão tende a aumentar mais.

A mistura que obteve melhor comportamento em relação à resistência à compressão foi a argamassa com $15 \%$ de CCA sem moer, ou seja, moída somente industrialmente. Os resultados permitem concluir que, além de um tempo ótimo de moagem, há também um teor ótimo de substituição do cimento por material pozolânico. Em termos de resistência, este teor seria $15 \%$ ou mais, mas a durabilidade tem papel condicionante no teor ótimo.

A adição de elevadas porcentagens de cinza de casca de arroz deve analisada com precaução, já que o ensaio de perda ao fogo indicou alto índice de carbono. Este elemento em grandes quantidades pode causar expansão, promovendo assim problemas de durabilidade. Altas porcentagens de cinza também podem resultar em fissuração causada pela reações expansivas do tipo álcali-sílica, isto porque a quantidade de sílica disponível na matriz torna-se maior.

O valor da resistência à tração por compressão diametral das argamassas manteve-se próximo a 10\% do valor da resistência à compressão. 
Os resultados de resistência à compressão em concretos apresentam comportamento adverso. Os valores não foram proporcionais ao consumo de cimento para todos os casos, como era esperado, tanto para as misturas com adição de CCA, como para as sem. Isto se deve à influência positiva da utilização de aditivo superplastificante nas misturas com finos. Nestes casos, as partículas tendem a se aglomerar e formar "flocos" (grumos), que têm área especifica muito menor que a das partículas que a formam. A conseqüência é uma hidratação menos eficiente, tanto pelo processo topoquímico como pela dissolução-precipitação. O aditivo superplastificante promove uma melhor dispersão das partículas, diminuindo a formação dos grumos e melhorando substancialmente a hidratação. A quantidade de aditivo necessária para a trabalhabilidade desejada nos concretos ricos foi muito baixa ou igual a zero, o que provavelmente não foi suficiente para possibilitar uma dispersão adequada das partículas. A melhoria causada pela boa hidratação que gerou o aditivo foi mais eficiente do ponto de vista da resistência à compressão que a maior quantidade de aglomerante do traço rico. Com isto, é possível concluir a importância da utilização de aditivos superplastificantes em misturas com muitos finos, como as que contêm cinza da casca de arroz.

Além disso, os resultados demonstram que é possível obter concretos de alta resistência com baixos consumos de cimento com um estudo adequado do traço, das características de cada componente e da sinergia entre eles. A incorporação da cinza da casca de arroz e a dosagem adequada de superplastificantes, no caso do traço de 1:6,5, propiciou um concreto com resistência à compressão aos 28 dias igual a 58MPa com um consumo de apenas $269 \mathrm{~kg} / \mathrm{m}^{3}$ de cimento. Além da vantagem econômica de se reduzir o consumo de cimento, ainda é possível reduzir fenômenos 
deletérios ao concreto, como a retração e a temperatura no interior do concreto. Com isto, minimiza-se a fissuração e, conseqüentemente, aumenta-se a durabilidade.

Quanto à resistência à tração e módulo de elasticidade, os ensaios mostraram que não houve mudanças significativas no comportamento das misturas de concreto com a adição de CCA em relação aos sem.

Comparando-se as resistências à compressão do concreto com traço de $1: 5$ e da argamassa com teor de $15 \%$ de CCA sem moer, observa-se que, em geral, as resistências da argamassa têm valores superiores. Isto demonstra que a zona de transição não foi totalmente eliminada dos concretos e que, por isso, não há a contribuição total da resistência do agregado.

As micrografias confirmaram o comportamento da CCA em relação à resistência à compressão, mostrando que o desenvolvimento da resistência se deu pela diminuição do tamanho e quantidade de vazios, e a conseqüente densificação da matriz da pasta com o avanço da idade. Além disso, algumas imagens, como a Figura 89, mostraram o produto $\mathrm{C}-\mathrm{S}-\mathrm{H}$ sobre a superfície de $\mathrm{CH}$, o que indica que ocorreu reação pozolânica mesmo em idades mais avançadas, no caso 28 dias.

Também em relação às micrografias, observa-se que com o desenvolvimento das idades, a quantidade e o tamanho dos vazios diminuem.

O aglomerante formado por cimento Portland e cinza da casca de arroz teve comportamento satisfatório em relação às propriedades avaliadas neste estudo, o que o torna viável para ser utilizado em concretos e argamassas. Considerando que o material hoje é considerado um entulho para a indústria do arroz, faz-se importante intensificar as pesquisas sobre este tipo de cinza de casca de arroz e divulgar os resultados. 


\section{SUGESTÕES DE PESQUISAS FUTURAS}

Considerando que a finura, principalmente em relação à formação de grumos, mostrou ser uma propriedade fundamental da CCA, seria conveniente um estudo mais aprofundado sobre o tempo de moagem ótimo da cinza de casca de arroz de termoelétrica do Rio Grande do Sul.

Para se confirmar a viabilidade do uso da CCA em compósitos à base de cimento, recomenda-se uma análise sobre a durabilidade, especialmente corrosão, carbonatação e reação álcali-sílica.

Para se conhecer o comportamento dos concretos com adição de cinza de casca de arroz em relação a esforços de flexão, poderiam ser executadas peças em escala natural.

Visto que o teor de $15 \%$ foi o que obteve o melhor desempenho em relação à resistência mecânica, sugere-se estudo de misturas com frações maiores de cinza da casca de arroz, respeitando as limitações quanto à durabilidade.

Uma avaliação sobre retração e calor de hidratação em misturas com e sem cinza de casca de arroz colaborariam para estimular o uso da CCA, mostrando que a vantagem da CCA sobre a sílica ativa de ferro-silício nestes aspectos.

Como a análise dos resultados da resistência à compressão dos concretos foi prejudicada pela grande influência que as misturas sofreram pela ação do superplastificante, um trabalho comparativo com misturas com adição de CCA e com diversos teores de aditivos superplastificantes seria muito importante. 


\section{REFERÊNCIAS}

1. AÏTCIN, P.C. (2003). The durability characteristics of high performance concrete: a review. Cement e Concrete Composites, v.25, n.4-5, p.409-420.

2. AïTCIN, P.C. (2000). Cement of yesterday and today. Concrete of tomorrow. Cement and Concrete Research. v.30, n.9 - September, p.1349-1359.

3. AÏTCIN, P.C. (2000). Concreto de alto desempenho, São Paulo: PINI.

4. AïTCIN, P.C.; NEVILLE, A. (2003). How the Water-Cement Ratio Affects Cancrete Strength. Concrete International. v.25, n.8 - August, p.51-58.

5. AMERICAN CONCRETE INSTITUTE. Committee 363 R. State-of-art report on high-strength concrete. ACl Manual of Concrete Practice, Detroit, 1992.

6. ASSOCIAÇÃO BRASILEIRA DE CIMENTO PORTLAND (2000). Manual de Ensaios Físicos de Cimento. São Paulo.

7. ASSOCIAÇÃO BRASILEIRA DE CIMENTO PORTLAND (2000). Manual de Ensaios de: Agregados, Concreto fresco e Concreto Endurecido. MT-6. São Paulo.

8. ASSOCIAÇÃO BRASILEIRA DE NORMAS TÉCNICAS. Agregado em estado compacto seco - Determinação da massa unitária - NBR 7810. Rio de Janeiro, 1983.

9. _ Agregado em estado solto - Determinação da massa unitária - NBR 7251. Rio de Janeiro, 1982.

10. Agregados - Determinação da composição granulométrica - NBR 7217. Rio de Janeiro, 1987.

11. Agregados para concreto - Especificação - NBR 7211. Rio de Janeiro, 1983.

12. Areia normal para ensaio - Especificação - NBR 7214. Rio de Janeiro, 1982.

13. Argamassa e concreto - Determinação de resistência à tração por compressão diametral de corpos-de-prova cilíndricos - NBR 7222. Rio de Janeiro, 1994.

14. Cimento Portland composto - NBR 11578. Rio de Janeiro, 1991. 
15. . Cimento Portland - Determinação do tempo de pega: Método de ensaio - NBR 11581. Rio de Janeiro, 1991.

16. Cimento Portland e outros materiais em pó - Determinação da massa específica: Método de ensaio - NBR 6474. Rio de Janeiro, 1984.

17. . Concreto - Determinação da consistência pelo abatimento do tronco de cone. NBR 7223. Rio de Janeiro, 1992.

18. . Concreto - Ensaio de compressão de corpos-de-prova cilíndricos. NBR 5739, Rio de Janeiro, 1994.

19. - Determinação da massa específica de agregados miúdos por meio de frasco de Chapman - NBR 9776. Rio de Janeiro, 1987.

20 . Determinação do teor de materiais pulverulentos nos agregados Método de ensaio. Rio de Janeiro, 1987.

21. Ensaio de cimento Portland: Método - NBR 7215. São Paulo, 1982.

22. _. Materiais Pozolânicos. NBR 12653. Rio de Janeiro, 1992.

23. _. Materiais Pozolânicos - Determinação de atividade pozolânica - Índice de atividade pozolânica com cal. NBR 5751. Rio de Janeiro, 1992.

24. - Materiais Pozolânicos - Determinação de atividade pozolânica com cimento Portland - Índice de atividade pozolânica com cimento. NBR 5752. Rio de Janeiro, 1992.

25. Moldagem e cura de corpos-de-prova cilíndricos ou prismáticos de concreto. NBR 5738. Rio de Janeiro, 1994.

26. . Projeto de Estruturas de concreto: Procedimento - NBR 6118. Rio de Janeiro, 2003.

27. BALTHAR, V. (2004). Retração autógena e evolução de propriedades mecânicas de pastas pozolânicas. Dissertação (Mestrado). Universidade Federal do Rio de Janeiro, Rio de Janeiro.

28. BARATA, M. S., DAL MOLIN, D. C. C. (2002). Avaliação preliminar do resíduo caulinítico das indústrias de beneficiamento de caulim como matéria-prima na produção de uma metacaulinita altamente reativa. Associação Nacional de Tecnologia do Ambiente Construído. v.2, n.1, p.69-78. Janeiro /março 2002, Porto Alegre. 
29. BENTUR, A. e COHEN, M. (1987). Effect of Condensed Silica Fume on the Microstructure of the Interfacial Zone in Portland Cement mortars. J. Amer. Ceram. Soc., v.70, n.10, p.738-743.

30. BENTZ, D. P. e GARBOCZI, E. J. (1992) Percolation of phases in a threedimensional cement paste microstructural model. Cement and Concrete Research. v.21, p.325-344.

31. BetTAGIN, A. F. (2004). Uma breve história do cimento Portland. $<$ http://www.abcp.org.br> (acesso em 18/07/2005).

32. BUI, D. D., HU, J., STROEVEN, P. (2005). Particle size effect on the strength of rice husk ash blended gap-graded Portland cement concrete. Cement \& Concrete Composites, n.27, p.357-366.

33. CHANDRA, S. (1997). 10th International Congress $n$ the Chemistry of Cement "Special Report". Cement and Concrete Research, USA, v.27, n.10, p.1613-1617.

34. CHANDRASEKHAR, S.; PRAMADA, P. N.; RAGHAVAN, P (2002). Microsilica from rice husk as a possible substitute for condensed sílica fume for high performance concrete. Journal of Materials Science Letters, v.21, p. 1245-1247.

35. COMITÉ EURO-INTERNACIONAL DU BÉTON. Diagnosis and Assessment of Concrete Structures - State of the Art Report. Bulletin d' Information nำ192. Janvier, 1998.

36. COSTENARO, F.L. (2003),Desenvolvimento de concretos com adição de cinza e sílica da casca do arroz. 165p. Dissertação (Mestrado). Escola de Engenharia de São Carlos, Universidade de São Paulo, São Carlos.

37. DAFICO, D. (2001). Estudo da dosagem do concreto de alto desempenho utilizando pozolanas provenientes da casca de arroz. Tese (Doutorado em Engenharia Mecânica) - Universidade Federal de Santa Catarina, Florianópolis.

38. DAL MOLIN, D. C. C. (1995). Contribuição ao estudo das propriedades mecânicas dos concretos de alta resistência com e sem adições de microssílica. São Paulo. Tese (Doutorado) - Escola Politécnica, USP.

39. FAGURY, S. C. e LIBORIO, J. B. L. (2004). Algumas considerações na utilização das cinzas da casca de arroz residual de termoelétricas como adição em concretos para estruturas costeiras: durabilidade e resistência mecânica. In: Jornadas Sud-Americanas de Ingeniería Estructural,31., 2004, Mendoza. 
Trabalho de evento... Mendoza: IMERIS/Universidad Nacional de Cuyo/ASAEE, 2004.

40. FERREIRA, A. A. \& DAL MOLIN D. C. C. \& CATEN C. S. (1999) Water absortion in rice-husk ash concretes. In: INTERNACIONAL CONFERENCE ON HIGHTPERFORMANCE CONCRETE, 1999, Gramado. Anais... Gramado: [s.n.].

41. GOLDMAN, A. e BENTUR, A. (1993). The influence of microfillers on enhancement of concrete strength. Cement and Concrete Research. v.23, p.962972, USA.

42. HELENE, P.R. L e TERZIAN, P. (1992) Manual de dosagem e controle do concreto. Pini: São Paulo.

43. INSTITUTO BRASILEIRO DE GEOGRAFIA E ESTATÍsTICA - IBGE. Previsão de safra para 2005. Disponível em:<www.sidra.ibge.gov.br>. Acesso em 15 de junho 2005.

44. ISAIA, G. C. (2005). Concreto: Ensino, Pesquisa e Realizações. v.1 - São Paulo: IBRACON.

45. KANTRO, D. L (1980). Influence of water-reducing admixtures on properties of cement paste - a miniature Slump Test. Cement, Concrete and Aggregate, v.2, n.2, p.95-102.

46. LEITE, M. B. DAL MOLIN, D. (2002). Avaliação da atividade pozolânica do material cerâmico presente no agregado reciclado de resíduo C\&D. Sitientibus, n.26, p.111-130, Janeiro/ junho, Feira de Santana.

47. LI, Y.; LANGAN, B. L., WARD, M. A. (1996). The strength and microstructure of high-strength paste containing silica fume. Cement, Concrete and Aggregates, v.18, n.2, p.112-117.

48. LIBORIO, J. B. L.,(2005). Notas de Aula da disciplina Tecnologia dos Concretos Estruturais da Pós-Graduação em Engenharia de Estruturas. Escola de Engenharia de São Carlos, Universidade de São Paulo.

49. LIBORIO. J. B. L. (2004). Concreto de Alto Desempenho - Uma Tecnologia Simples Para a Produção de Concretos Duráveis. Revista Téchne. Editora Pini Dezembro de 2004, São Paulo.

50. LIBORIO, J. B. L., SOUZA, M. F., BATISTA, P.S. (2001). Processo de extração da sílica contida na casca e na planta de arroz. PI 9903208-2 A. 
51. LIMA, S. M. (2006). Concreto de alto desempenho em ambientes com baixas temperaturas. São Carlos: Departamento de Engenharia de Estruturas - EESC. Dissertação (Mestrado). USP.

52. MEHTA, P. K. (1992) Rice Husk Ash - A unique supplementary cement material proceedings of the international symposium on advances in concrete technology. Athens, Greece, p.407-430, May 1992.

53. MEHTA, P.K., MONTEIRO, P.J.M. (1994), Concreto: estrutura, propriedades e materiais, São Paulo: Pini.

54. MEHTA, P. K. e FOLLIARD, K. J. (1992). Rice Husk Ash - A unique supplementary cement: durability aspects. In: Malhotra. Advances in Concrete, CANMET - p.531-541.

55. MELO, A.B. (2000). Influência de cura térmica (vapor) sob pressão atmosférica no desenvolvimento da microestrutura dos concretos de cimento Portland. 2000. Tese (Doutorado) - Interunidades em Ciências e Engenharia de Materiais, EESC - IQSC - IFSC, Universidade de São Paulo.

56. MOURA, W. A. (2000). Utilização de escória de cobre como adição e como agregado miúdo para concreto. Tese (Doutorado). Universidade Federal do Rio Grande do Sul, Porto Alegre.

57. NEHDI, M.; DUQUETTE, J.; DAMATTY, A (2003). Performance of rice husk ash produced using a new technology as a mineral admixture in concrete. Cement and Concrete Reserch,n.33, p.1203-1210, USA.

58. NEVILLE, A.M. (1997), Propriedades do concreto, São Paulo, PINI.

59. NUNES, N. L. (1998). Estudo da influência da geometria da fibra de aço na tenacidade à flexão dos compósitos de matriz de concreto. Dissertação (Mestrado). Escola Politécnica da Universidade de São Paulo, São Paulo.

60. OLIVEIRA, C. A. S. (2004). Comportamento físico e avaliação microestrutural de argamassas produzidas a partir da mistura exaurida gerada na indústria de magnésio metálico. Dissertação (Mestrado). Curso de Pós-graduação em Engenharia Metalúrgica e de Minas, Universidade Federal de Minas Gerais, Belo Horizonte.

61. PRUDÊNCIO, L. R., SANTOS, S., DAFICO, D. A. (2003). Coletânea Habitare. v.4. A Utilização de Resíduos na Construção Habitacional. p.241-261. 
62. Reported by ACl Committee 211 - ACl 211.4 -93 - Guide for Selecting Propotions for High-Strength Concrete With Portland Cement and Fly Ash, October 1993.

63. RICHARD, P. (1996). Reactive powder concrete: A new ultra-high-strength cementitious material. In: INTERNATIONAL SYMPOSIUM OF HIGH STRENGTH/HIGH PERFORMANCE CONCRETE, 4, 1996, Paris, France. Anais... Paris. p.1343-1349.

64. ROSSIGNOLO, J. A. (2003). Concreto leve de alto desempenho modificado com SB para pré-fabricados esbeltos - dosagem, produção, propriedades e microestrutura. Tese (Doutorado) - Interunidades em Ciências e Engenharia de Materiais, EESC - IQSC - IFSC, Universidade de São Paulo.

65. ROVERE, E. L. (2003). A utilização de casca de arroz na cogeração de energia e a decorrente mitigação de gases que contribuem para o efeito estufa como mecanismo de desenvolvimento limpo. Rio de Janeiro, RJ. <http://www.centroclima.org.br/FNMA_arroz.pdf> (acesso em 04/01/2006).

66. SANTOS, S. (1997). Estudo de viabilidade de utilização da cinza de casca de arroz residual em argamassas e concretos. Dissertação (Mestrado) Universidade Federal de Santa Catarina, 1997.

67. SCRIVENER, K.L. (1989). The microstructures of concrete. In: SKALNY, J. Materials science of concrete. U.S.A.: The American Ceramic Society, Inc., 1989, p.127-161.

68. SENSALE, G. R. B. (2000). Estudo comparativo entre as propriedades mecânicas dos concretos de alta resistência e convencionais com cinza de casca de arroz. Porto Alegre: programa de Pós-graduação em engenharia Civil. Tese (Doutorado). Universidade Federal do Rio Grande do Sul.

69. SENSALE, G. R. B. (2006). Strength development of concrete with rice-husk ash. Cement and Concrete Composites, n.28, p.158-160, USA.

70. SILVA, F. G. (2004). Estudo da resistência à corrosão do concreto de alto desempenho frente à ação de cloretos. Qualificação (Doutorado) - Ciência e Engenharia de Materiais - Interunidades EESC - IFSC - IQSC, Universidade de São Paulo, 2004.

71. SILVA, F. G. (2004). O emprego do potencial de corrosão como método de monitoramento da corrosão em estruturas de concreto armado. In: XXXI 
JORNADAS SUD-AMERICANAS DE INGENIERÍA ESTRUCTURAL, 2004, Mendoza, Argentina.

72. SILVA, I. J. (2000). Contribuição ao estudo dos concretos de elevado desempenho: propriedades mecânicas, durabilidade e microestrutura. São Carlos: Departamento de Engenharia de Estruturas - EESC. Tese (Doutorado). USP, 1999.

73. SILVA, I. J. e LIBORIO, J. B. L. (1999). O efeito da sílica ativa no desenvolvimento da microestrutura de concretos de alto desempenho e sua interferência na estrutura porosa de pasta e concreto de cimento Portland. In: Simpósio Interunidades em Ciência e Engenharia dos Materias, 2.,1999, São Carlos. Resumo de trabalho.. .São Carlos: USP - EESC, 1999. p. 102-103.

74. TAKEYA, T. (2001). Notas de Aula: Análise Experimental de Estruturas. São Carlos, USP - Departamento de Engenharia de Estruturas - EESC.

75. TAYLOR, H. F. W. (1992). Cement Chimistry. Academic Press Ltd, London.

76. VANDERLEI, R. D. (2004). Análise do concreto de pós reativos: dosagem e propriedades mecânicas. São Carlos: Departamento de Engenharia de Estruturas - EESC. Tese (Doutorado). USP, 2000.

77. ZHANG, M. H.; MALHOTRA, V. M. (1996). High-performance Concrete incorporating Rice Husk Ash as a Supplementary Cementing Material. ACl Materials Journal, v.93, n.6, November/December, p.629-636.

78. ZHANG, M. H.; LASTRA R.; MALHOTRA, V. M. (1996). Rice husk ash paste and concrete: some aspects of hydration and the microstructure of the interfacial zone between the aggregate and paste. Cement and Concrete Reserch, v.33, n.6, p.963-977, USA. 
ANEXO A

Resultados dos ensaios com os corpos-de-prova de argamassa padrão.

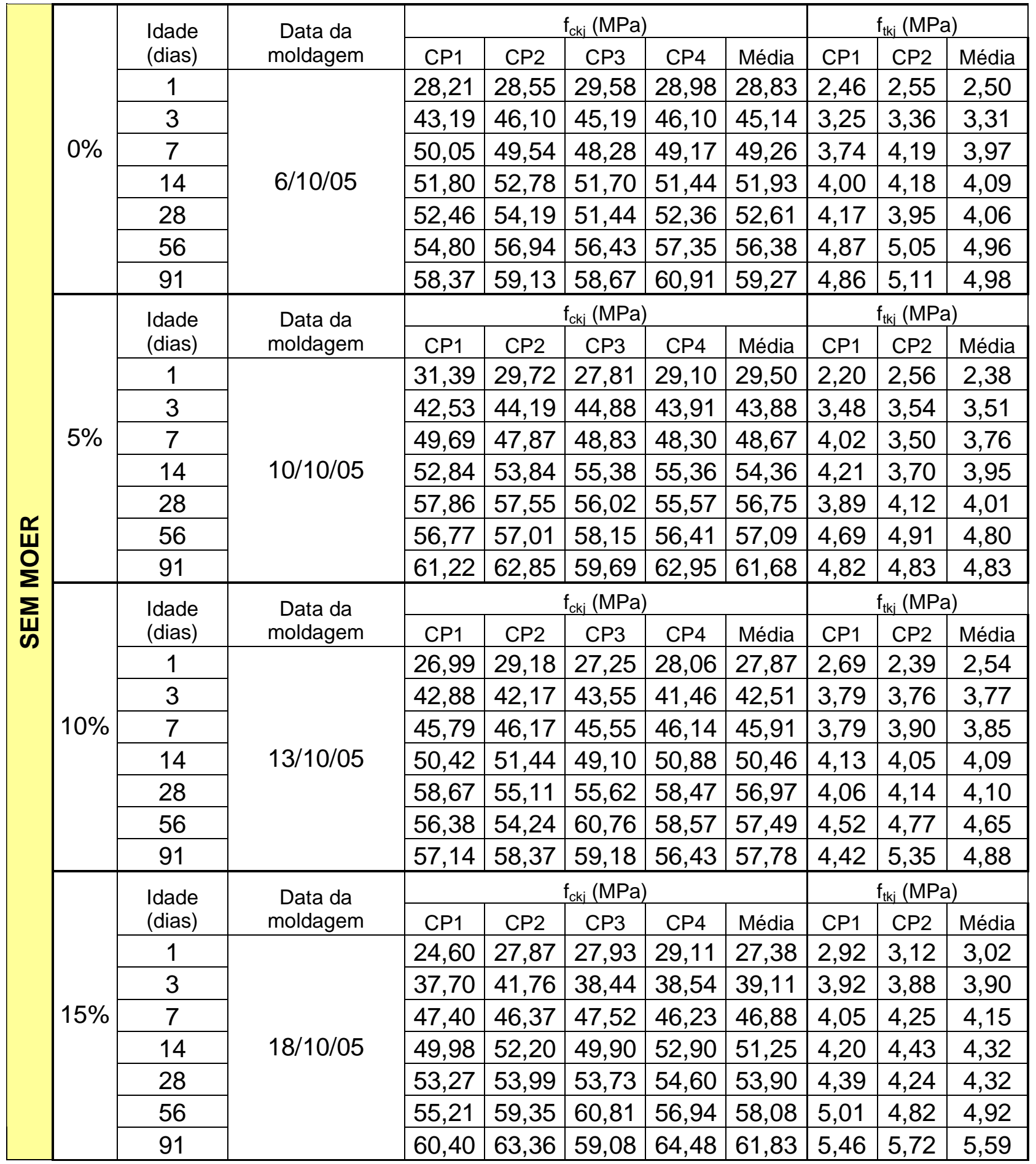




\begin{tabular}{|c|c|c|c|c|c|c|c|c|c|c|c|}
\hline \multirow{9}{*}{\multicolumn{2}{|c|}{$5 \%$}} & \multirow{2}{*}{$\begin{array}{l}\text { Idade } \\
\text { (dias) }\end{array}$} & \multirow{2}{*}{$\begin{array}{c}\text { Data da } \\
\text { moldagem }\end{array}$} & \multicolumn{5}{|c|}{$\mathrm{f}_{\mathrm{ckj}}(\mathrm{MPa})$} & \multicolumn{3}{|c|}{$\mathrm{f}_{\mathrm{tkj}}(\mathrm{MPa})$} \\
\hline & & & & $\mathrm{CP} 1$ & $\mathrm{CP} 2$ & CP3 & $\mathrm{CP} 4$ & Média & CP1 & CP2 & Média \\
\hline & & 1 & & 28,11 & 30,27 & 30,52 & 31,29 & 30,69 & 2,52 & 2,90 & 2,71 \\
\hline & & 3 & & 49,71 & 49,92 & 47,97 & 48,25 & 48,96 & 3,20 & 3,73 & 3,46 \\
\hline & & 7 & & 51,00 & 51,29 & 50,91 & 50,80 & 50,90 & 3,64 & 3,71 & 3,67 \\
\hline & & 14 & 20/10/05 & 51,90 & 52,52 & 52,93 & 55,77 & 53,28 & 4,71 & 4,41 & 4,56 \\
\hline & & 28 & & 56,13 & 54,70 & 56,43 & 53,27 & 55,13 & 4,82 & 4,41 & 4,61 \\
\hline & & 56 & & 59,60 & 56,33 & 54,72 & 59,11 & 57,44 & 4,53 & 4,70 & 4,62 \\
\hline & & 91 & & 62,44 & 65,50 & 67,23 & 64,53 & 64,93 & 5,05 & 5,13 & 5,09 \\
\hline \multirow{18}{*}{ 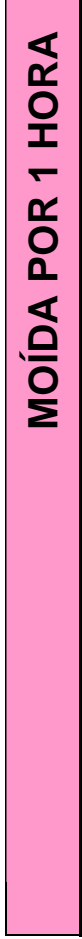 } & \multirow{9}{*}{$10 \%$} & Idade & & \multicolumn{5}{|c|}{$\mathrm{f}_{\mathrm{cki}}(\mathrm{MPa})$} & \multicolumn{3}{|c|}{$\mathrm{f}_{\mathrm{tkj}}(\mathrm{MPa})$} \\
\hline & & (dias) & 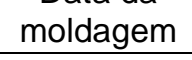 & $\mathrm{CP} 1$ & $\mathrm{CP} 2$ & CP3 & $\mathrm{CP} 4$ & Média & CP1 & CP2 & Média \\
\hline & & 1 & \multirow{7}{*}{ 22/11/05 } & 20,22 & 19,33 & 20,60 & 19,31 & 19,86 & 2,48 & 2,37 & 2,43 \\
\hline & & 3 & & 39,12 & 41,76 & 37,28 & 37,59 & 38,94 & 3,49 & 2,61 & 3,05 \\
\hline & & 7 & & 43,60 & 44,11 & 45,84 & 47,91 & 45,36 & 4,04 & 3,50 & 3,77 \\
\hline & & 14 & & 49,65 & 48,68 & 50,17 & 51,00 & 49,88 & 3,79 & 3,91 & 3,85 \\
\hline & & 28 & & 54,29 & 57,25 & 54,26 & 57,03 & 55,71 & 3,95 & 4,31 & 4,13 \\
\hline & & 56 & & 55,82 & 57,76 & 58,57 & 56,33 & 57,12 & 4,59 & 4,47 & 4,53 \\
\hline & & 91 & & 58,01 & 60,61 & 58,67 & 55,11 & 58,10 & 4,46 & 4,58 & 4,52 \\
\hline & \multirow{9}{*}{$15 \%$} & Idade & \multirow{2}{*}{$\begin{array}{c}\text { Data da } \\
\text { moldagem }\end{array}$} & \multicolumn{5}{|c|}{$\mathrm{f}_{\mathrm{ckj}}(\mathrm{MPa})$} & \multicolumn{3}{|c|}{$\mathrm{f}_{\mathrm{tkj}}(\mathrm{MPa})$} \\
\hline & & (dias) & & $\mathrm{CP} 1$ & $\mathrm{CP} 2$ & CP3 & $\mathrm{CP} 4$ & Média & CP1 & $\mathrm{CP} 2$ & Média \\
\hline & & 1 & \multirow{7}{*}{$24 / 11 / 05$} & 19,28 & 18,84 & 19,18 & 20,07 & 19,34 & 2,13 & 2,12 & 2,12 \\
\hline & & 3 & & 37,89 & 38,10 & 38,91 & 34,53 & 37,36 & 3,65 & 4,09 & 3,87 \\
\hline & & 7 & & 45,43 & 44,21 & 44,02 & 46,25 & 44,98 & 4,29 & 4,06 & 4,18 \\
\hline & & 14 & & 48,47 & 52,36 & 50,19 & 49,01 & 50,01 & 4,18 & 4,31 & 4,25 \\
\hline & & 28 & & 53,53 & 52,00 & 55,77 & 50,48 & 52,95 & 4,60 & 4,45 & 4,52 \\
\hline & & 56 & & 55,72 & 57,45 & 57,14 & 60,64 & 57,74 & 4,45 & 4,56 & 4,50 \\
\hline & & 91 & & 63,26 & 64,89 & 63,31 & 63,56 & 63,76 & 5,56 & 5,47 & 5,51 \\
\hline
\end{tabular}


ANEXO B

Resultados dos ensaios com os corpos-de-prova de concreto. Admitiu-se desvio padrão máximo de 4MPa. Os resultados na cor laranja foram desconsiderados.

\begin{tabular}{|c|c|c|c|c|c|c|c|}
\hline \multirow{18}{*}{ 过 } & \multirow{6}{*}{$\stackrel{n}{\mathscr{n}}$} & \multirow{2}{*}{$\begin{array}{l}\text { Idade } \\
\text { (dias) }\end{array}$} & \multirow{2}{*}{$\begin{array}{c}\text { Data da } \\
\text { moldagem }\end{array}$} & \multicolumn{4}{|c|}{$\mathrm{f}_{\mathrm{ckj}}(\mathrm{MPa})$} \\
\hline & & & & CP1 & CP2 & CP3 & Média \\
\hline & & \multirow{2}{*}{$\frac{3}{7}$} & \multirow{4}{*}{$25 / 04 / 07$} & 40,30 & 37,50 & 39,40 & 39,07 \\
\hline & & & & 40,90 & 42,90 & 36,30 & 40,03 \\
\hline & & \multirow{2}{*}{$\frac{28}{60}$} & & 49,20 & 48,30 & 49,30 & 48,93 \\
\hline & & & & 49,70 & 52,20 & 54,30 & 52,07 \\
\hline & \multirow{6}{*}{$\stackrel{\text { Pִ }}{\leftarrow}$} & \multirow{2}{*}{$\begin{array}{l}\text { Idade } \\
\text { (dias) }\end{array}$} & \multirow{2}{*}{$\begin{array}{c}\text { Data da } \\
\text { moldagem }\end{array}$} & \multicolumn{4}{|c|}{$\mathrm{f}_{\mathrm{ckj}}(\mathrm{MPa})$} \\
\hline & & & & $\overline{\mathrm{CP} 1}$ & CP2 & CP3 & Média \\
\hline & & 3 & \multirow{4}{*}{$25 / 04 / 07$} & 34,80 & 44,30 & 49,20 & 46,75 \\
\hline & & 7 & & 52,60 & 50,30 & 46,10 & 49.67 \\
\hline & & 28 & & 67,60 & 59,60 & 63,30 & 63,50 \\
\hline & & 60 & & 65,30 & 47,10 & 64,20 & 64,75 \\
\hline & \multirow{6}{*}{ بْ } & Idade & \multirow{2}{*}{$\begin{array}{c}\text { Data da } \\
\text { moldagem }\end{array}$} & \multicolumn{4}{|c|}{$\overline{f_{c k j}(M P a)}$} \\
\hline & & (dias) & & $\mathrm{CP} 1$ & CP2 & CP3 & Média \\
\hline & & 3 & \multirow{4}{*}{ 02/05/07 } & 45,10 & 43,00 & 47,30 & 45,13 \\
\hline & & 7 & & 42,20 & 54,10 & 49,20 & 51,65 \\
\hline & & 28 & & 51,30 & 54,00 & 59,10 & 54,80 \\
\hline & & 60 & & 62,30 & 58,20 & 58,40 & 59,63 \\
\hline
\end{tabular}

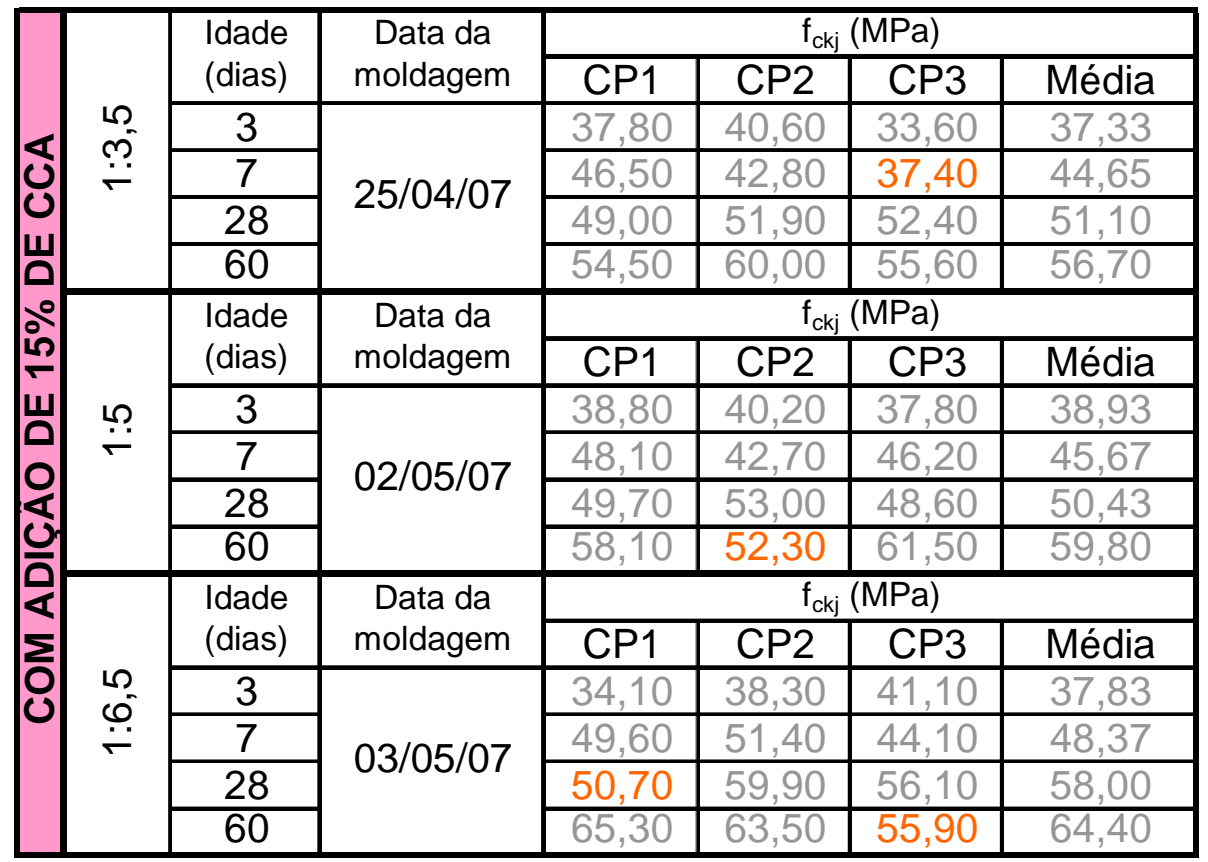

